\title{
POTENCIAL DE GERMOPLASMA DE MILHO PARA A SÍNTESE DE COMPOSTOS COM ADAPTAÇÃO A SOLO ÁCIDO
}

\section{CAMILO DE LELIS MORELLO}

Engenheiro Agrônomo

Orientador: Prof. Dr. JOSÉ BRANCO DE MIRANDA FILHO

Tese apresentada à Escola Superior de Agricultura "Luiz de Queiroz", Universidade de São Paulo, para obtenção do titulo de Doutor em Agronomia, Área de Concentração: Genética e Melhoramento de Plantas.

\section{PIRACICABA}

Estado de São Paulo - Brasil

Julho -2000 
Dados Internacionais de Catalogaçāo na Publicação (CIP)

DIVISÃO DE BIBLIOTECA E DOCUMENTAÇĀO - Campus "Luíz de OueirOz"/USP

\author{
Morello, Camilo de Lelis \\ Potencial de germoplasma de milho para a síntese de compostos com adaptação a soio \\ ácido / Camilo de Lelis Morello. - - Piracicaba, 2000. \\ $132 \mathrm{p}$. \\ Tese (doutorado) - Escola Superior de Agricultura Luiz de Queiroz, 2000. \\ Bibliografia. \\ 1. Cruzamento dialélico 2. Germoplasma 3. Melhoramento genético vegetal 4. Milho \\ 5. Solo ácido 6. Solução nutritiva 7. Tolerância ao alumínio I. Título
}

CDD 633.15

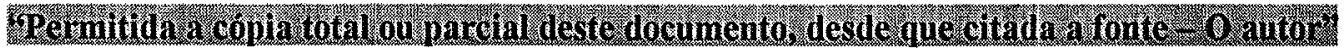


Aos meus familiares,

presentes mesmo na distância,

pelos incentivos e apoio,

DEDICO.

À Regina e Alícia, pela vida e pelo amor que compartilhamos, OFEREÇO. 


\section{AGRADECIMENTOS}

À Universidade do Tocantins. pela oportunidade de qualificação;

À Escola Superior de Agricultura "Luiz de Queiroz"/Universidade de São Paulo, pela oportunidade da realização do Curso;

À Coordenação de Aperfeiçoamento de Pessoal de Ensino Superior - CAPES, pela bolsa de estudos;

Ao Prof. Dr. José Branco de Miranda Filho, pela orientação, amizade e oportunidade de convivio:

À Profa. Regina Melo Sartori Coêlho Morello, pelo incentivo, apoio, paciência e colaboração durante o Curso e realização deste trabalho;

Ao Dr. Luciano Lourenço Nass, pelas contribuições e amizade;

Ao Prof. Dr. Claudio Lopes de Souza Junior, em nome dos demais professores da ESALQ/USP, pelos ensinamentos;

Aos colegas Dra. Eliana Patricia Gorgulho, Dr. Josué Maldonado Ferreira, Dr. Dario Rosa Mesquita Neto e Dr. Amadeu Regitano Neto, pelas sementes e informações necessárias à primeira etapa deste trabalho;

Ao Dr. Pedro Roberto Furlani, pela atenção e colaboração na realização das avalições em solução nutritiva;

Ao Dr. Manoel Xavier dos Santos, pelo constante apoio e amizade;

Aos funcionários Claudio Segateli, Marcos Cella e José Monteiro, em nome dos demais funcionários do Departamento de Genética da ESALQ/USP, pela colaboração durante o Curso e realização deste trabalho; 
Aos amigos e colegas de Curso, Juan Carlos, Pedro, Ricardo, Flávio, João Batista, Carlos Giaveno, Carlos Basso, Pilar, Felix. Andréia, Angela, Rogério, Leonardo, Dario, Marcelo e Josué, entre outros, pela troca de experiências e conhecimentos e pela colaboração e convívio:

Aos amigos e colegas da Universidade do Tocantins, Gerson, Kênia, Joênes, Dirceu, Edson, Eduardo, Alan, entre outros, pelo incentivo e apoio ;

Aos amigos Celia e Renato, Juliana e Paulo, pelo companheirismo, apoio e tantos momentos agradáveis.

À Deus pai, pela oportunidade da vida e, neste momento, por permitir esta pequena contribuição; 
SUMÁRIO

Página

RESUMO.

vii

SUMMARY.

INTRODUÇÃO.

REVISÃO DE LITERATURA.

2.1 Solos ácidos e efeitos no desenvolvimento de plantas de milho

2.2 Herança, variabilidade genética, heterose e capacidade combinatória em caracteres em solos ácidos.

2.3 Cruzamentos dialélicos e "top crosses" no melhoramento de milho......... 12

$2.4 \quad$ Predição de médias de compostos de variedades................................. 16

$2.5 \quad$ Germoplasma de milho............................................................................ 18

$3 \quad$ MATERIAL E MÉTODOS.............................................................. 23

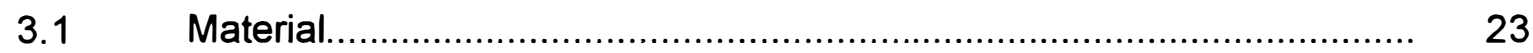

3.1.1 Avaliação de variedades de milho em solo ácido (experimentos 1 a 5)... 23

3.1.2 Crescimento de radicula em solução nutritiva (experimento 6)............... 26

3.1.3 Cruzamento dialélico e predição de compostos com adaptação a solo ácido (experimentos 7 e 8)............................................................. 27

$3.2 \quad$ Métodos

3.2.1 Avaliação de variedades de milho em solo ácido (experimentos 1 a 5)... 29

3.2.1.1 Execução experimental.................................................................... 29

3.2.1.2 Análises estatístico-genéticas.......................................................... 30

3.2.2 Crescimento de radicula em solução nutritiva (experimento 6)................ 35

3.2.2.1 Execução experimental.................................................................. 35

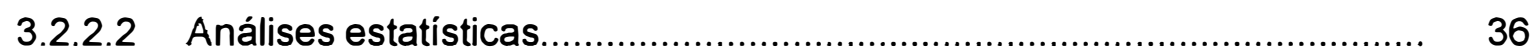

3.2.3 Cruzamento dialélico e predição de compostos com adaptação a solo ácido (experimentos 7 e 8)........................................................... 37

3.2.3.1 Execução experimental.............................................................. 37

3.2.3.2 Análises estatístico-genéticas............................................................. 38

3.2.3.3 Predição de médias de compostos...................................................... 41 
4.1 Avaliação de variedades de milho em solo ácido............................... 42

4.1.1 Cruzamento dialélico parcial (experimento 1) ................................. 43

4.1.2 Cruzamento dialélico (experimento 2) ........................................... 49

4.1.3 Cruzamento "top cross" intragrupo (experimento 3) ........................... 53

4.1.4 Avaliação de variedades "per se" (experimento 4) ............................... 56

4.1.5 Avaliação de variedades "per se" (experimento 5) ............................ 57

4.2 Crescimento de radícula em solução nutritiva (experimento 6)............... 59

4.3 Cruzamento dialélico e predição de compostos com adaptação a

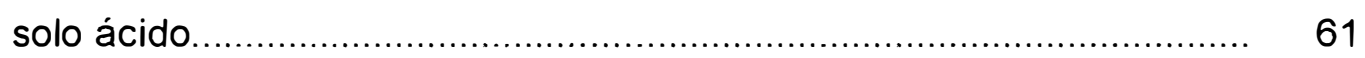

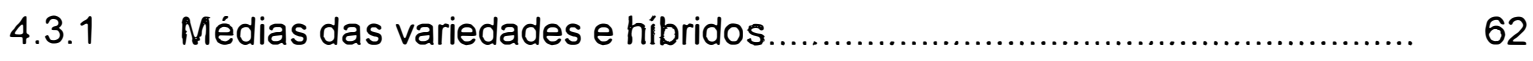

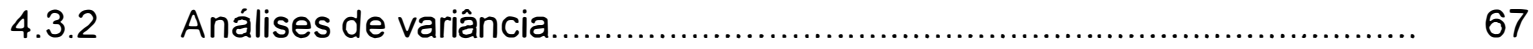

4.3.3 Estimativas de parâmetros.................................................. 69

4.3.4 Predição de médias de compostos................................................. 72

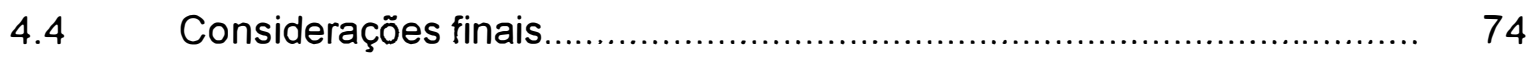

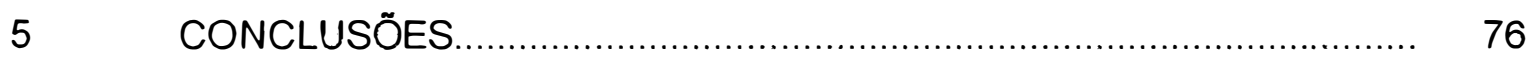

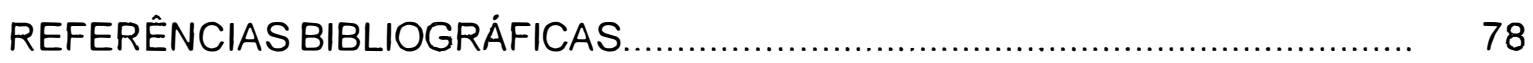

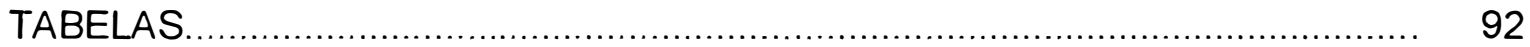

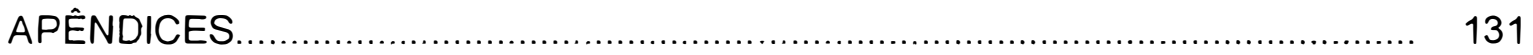




\title{
POTENCIAL DE GERMOPLASMA DE MILHO PARA A SÍNTESE DE COMPOSTOS COM ADAPTAÇÃO A SOLO ÁCIDO
}

\author{
Autor: CAMILO DE LELIS MORELLO \\ Orientador: Prof. Dr. JOSÉ BRANCO DE MIRANDA FILHO
}

\section{RESUMO}

Os solos ácidos constituem uma grande parte das áreas agricolas no mundo. No Brasil, os solos sob vegetação de "cerrado", de natureza ácida, correspondem a aproximadamente 150 milhões de hectares, representando aproximadamente $25 \%$ da área agricola total (EMBRAPA, 1978). A utilização dessas áreas para fins agricolas, torna-se possivel e economicamente viável, a partir da integração de práticas de manejo, como a aplicação de calcário e fosfato e o emprego de cultivares adaptados. Para o sucesso no desenvolvimento de cultivares com adaptação a solos ácidos, faz-se fundamental o emprego de germoplasma com variabilidade genética para adaptação à referida condição. $O$ objetivo deste estudo foi identificar germoplasma de milho com adaptação ao complexo solo ácido e tolerância ao alumínio, e posteriormente verificar o potencial desse germoplasma para a síntese de compostos com adaptação a solo ácido.

No ano agricola 1997/98, cinco experimentos, compreendendo 158 variedades e 122 hibridos intervarietais, foram avaliados em condição de solo ácido, em Anhembi, SP. Nos experimentos 1, 2 e 3, foram selecionadas, em cada, as variedades com as maiores estimativas positivas de capacidade geral de combinação (CGC), para o caráter peso de espigas (PE). Nos experimentos 4 e 5 , foram selecionadas as variedades com as maiores médias para $\circ \mathrm{PE}$. Essas variedades foram empregadas na etapa seguinte do estudo, referente a avaliação para tolerância ao alumínio. 
No experimento 1. foram selecionadas as variedades TAITINGA. TAIÚBA e WP 12, do Grupo [1], e as variedades CUPURICO DMR e TUXPEÑO AMARILLO, do Grupo [2]. As variedades PMI 8701 e BR 105, foram as selecionadas no experimento 2. No experimento 3, foram selecionadas as variedades CMS 53, CMS 28, CMS 54. CMS 4N, BR 111 , SUWAN 2, PC 9405 e CMS 57NF. As variedades BA 115, BA 191, BA 176, SE 036, WP 32, PUEBLA GRUPO 27, AL 009, SIKALQ e MS 010, com as maiores médias de PE, foram as selcionadas no experimento 4 , e no experimento 5 , foram selecionadas as variedades CMS 39, CMS 463, [(CUBA $173 \times \mathrm{B}$ 73) $\times$ BR 106], BS $16 \times$ BR 105, [(CUBA $117 \times B$ 73) $\times$ BR 105], [(CUBA $117 \times B$ 73) $\times$ BR 106], [(CUBA $110 \times M O 17) \times B R$ 105], ANTIGUA 3 × BR 106, IODENT x BR 106 e BS $29 \times$ BR 106.

As 34 variedades selecionadas quanto a adaptação a solo ácido, no mês julho de 1998, foram avaliadas em solução nutritiva contendo aluminio em nivel tóxico, tomandose o crescimento de radicula como variável. As amplitudes de valores de comprimento liquido de radicula $(C L)$ foram de $6,36 \mathrm{~cm}$ a $13,44 \mathrm{~cm}$. Esses valores em relação as tetemunhas telorante (DINA 766) e sensivel (MITLA 9560) foram de 0,43 a 0,91 e 1,07 a 2,26, respectivamente. Destacaram-se as variedades TAITINGA, SIKALQ, TAIÚBA, BR $105 \mathrm{~V}$, SUWAN 2, CMS 39, CMS 57NF, AL 009, CUPURICO DMR e CMS 53, em ordem decrescente de valores de $C L$.

As dez variedades com maior crescimento de radicula em presença de aluminio, também verificadas quanto a adaptação a solo ácido, foram submetidas a cruzamento dialélico. Em 1998/99, no periodo de "safrinha", essas dez variedades e seus 45 hibridos foram avaliados em Anhembi, SP, em dois experimentos, correspondentes a dois niveis de acidez e disponibilidade de nutrientes. Em ambos os experimentos, efeitos significativos foram verificados nos caracteres altura da planta (AP), altura da espiga (AE), comprimento da espiga (CE), diâmetro da espiga (DE) e peso de grãos (PG). Para os caracteres de produção, os efeitos de interações entre efeitos de variedades $x$ experimentos, efeitos de heterose $x$ experimentos e efeitos de CGC $x$ experimentos, foram não significativos, permitindo a análise e seleção de variedades considerando-se a média dos experimentos.

Para o PG, as variedades CMS 39, CMS 57NF e SIKALQ destacaram-se por apresentarem os maiores efeitos de variedades. A variedade AL 009 foi a de maior efeito de heterose de variedade, porém apresentou o menor valor para efeito de variedade. As variedades BR 105 e CMS 39 apresentaram as maiores estimativas de CGC e o cruzamento TAITINGA x CMS 39 apresentou o maior efeito de heterose especifica. De 
modo geral, para os caracteres $A P$ e $A E$, as estimativas ocorreram com valores aceitáveis, não inviabilizando a utilização dessas variedades.

Utilizando-se o indice $I_{i}$, para o PG, foram selecionadas as variedades CMS 39 , BR $105 \mathrm{~V}$, SIKALQ, CMS 57NF e TAITINGA para participarem das predições de compostos. As médias de compostos preditos, para o PG, foram entre 3,71 t/ha a 4,39 t/ha. O composto de tamanho $k=2$, a partir do cruzamento TAITINGA $\times$ CMS 39, obteve a maior média predita, com 4,39 t/ha. Entre os compostos de tamanho $k=3$, destacou-se 0 composto TAITINGA $\times$ SIKALQ $\times$ CMS 39, com 4,30 t/ha. A maior média predita para composto $\mathrm{k}=4$ foi de 4,22 t/ha, com o composto TAITINGA $\times$ SIKALQ x CMS $39 \times$ BR 105 . O composto amplo, com $k=5$, envolvendo as cinco variedades, obteve média predita de 4,13 t/ha. 


\title{
POTENTIAL OF MAIZE GERMPLASM FOR THE SYNTHESIS OF COMPOSITES
} WITH ADAPTATION TO ACID SOIL

\author{
Author: CAMILO DE LELIS MORELLO \\ Adviser: Prof. Dr. JOSÉ BRANCO DE MIRANDA FILHO
}

\section{SUMMARY}

Acid soils represent a large portion of the agricultural areas in the world. In Brazil, acid soils under the "cerrado" vegetation represent approximately 150 millions hectares or $25 \%$ of the total area (EMBRAPA, 1978). The use of the "cerrado" areas for agricultural purposes may be economically feasible by integrating agricultural practices such as the application of lime and phosphate with the use of adapted cultivars. For the success of developing adapted cultivars, the base germplasm must be characterized by the existence of genetic variability for adaptation to that condition. The objective of this study was the identification of maize germplasm with adaptation to the acid soil and aluminum tolerance complex; and further to get information on the value of such germplasm for the synthesis of composites with adaptation to acid soil.

In the year 1997/98, five experiments comprising 158 populations and 122 population crosses were conducted under the condition of acid soil in Anhembi (SP). In the experiments 1, 2 and 3, varieties exhibiting the largest and positive estimates of general combining ability (CGC) effects for yield were selected. In the experiments 4 and 5 , populations were selected on the basis of only yield per se. All the selected populations were used in the next step of the program, referring to the evaluation for aluminum tolerance.

From experiment 1 , the following populations were selected: TAITINGA, TAIUBA and WP 12 in group [1]; and CUPURICO DMR and TUXPEÑO AMARILLO from group [2]. Populations PMI 8701 and BR 105 were selected from experiment 2. From experiment 3 , 
the following populations were selected: CMS 53, CMS 28, CMS 54, CMS 4N, BR 111, SUWAN 2, PC 9405 and CMS 57 NF. From experiment 4, the following populations were selected: BA 115, BA 191, BA 176, SE 036, WP 32, PUEBLA GRUPO 27, AL 009, SIKALQ, and MS 010. From experiment 5, the following populations were selected: CMS 39, CMS 463, [(CUBA $173 \times$ B73) $\times$ BR 106], BS $16 \times$ BR 105, [(CUBA $117 \times$ B73) $\times$ BR 105], [(CUBA $117 \times B$ 73) $\times$ BR 106], [(CUBA $110 \times$ MO 17) $\times$ BR 105], ANTIGUA $3 \times B R$ 106, IODENT $\times$ BR 106, and BS $29 \times$ BR 106.

The 34 populations, selected for adaptation to acid soil, were evaluated for the variable "net growth rate of the radicle" $(\mathrm{CL})$ in nutrient solution with toxic aluminum. The range for $C L$ was from $6.36 \mathrm{~cm}$ to $13.44 \mathrm{~cm}$; these values expressed in relation to the mean of the tolerant check (DINA 766) and sensitive check (MITLA9560) range from 0.43 to 0.91 and from 1.07 to 2.26, respectively. Outstanding performances were to TAITINGA, SIKALQ, TAIÚBA, BR $105 \mathrm{~V}$, SUWAN 2, CMS 39, CMS 57 NF, AL 009, CUPURICO DMR and CMS 53, in decreasing order for CL. The ten populations with higher $C L$ and good adaptation to acid soil were crossed according to the diallel mating scheme. In 1998/99, the ten populations and their 45 crosses were evaluated in off-season crop in Anhembi, under two environments differing by the amount of available nutrients and level of acidity in the soil. In both experiments, significant variation was detected for plant height, ear height, ear length, ear diameter, and grain yield. For the traits of production, the effects of the interaction of varieties, heterosis and general combining ability with environments were non significant, which allowed the data analysis and selection of varieties on the average of both environments.

Populations CMS 39, CMS 57NF and SIKALQ were outstanding for grain yield for grain yield, exhibiting the highest and positive variety effects. The highest negative variety effect was for AL 009 which, however, showed the highest positive variety heterosis effect. Populations BR 105 and CMS 39 showed the highest estimates for general combining ability, while the cross TAITINGA x CMS 39 showed the highest specific heterosis effects. In general plant height and ear height did not depart greately in those selected populations and will not preclude their use in the synthesis of new populations.

The index $\mathrm{l}_{\mathrm{j}}$ was used for grain yield to select populations CMS 39, BR $105 \mathrm{~V}$, SIKALQ, CMS 57NF, and TAITINGA to be used as parents in the synthesis of new composites based on predicted means. Predicted means of composites were in the range of 3.71 tha to $4.39 \mathrm{t} / \mathrm{ha}$. The highest predicted mean was for the composite TAITINGA $x$ CMS 39 (size $k=2$ ). Among composites of size $k=3$ and $k=4$, the highest predicted means 
were 4.30 t/ha (TAITINGA $\times$ SIKALQ $\times$ CMS 39) and 4.22 t/ha (TAITINGA $\times$ SIKALQ $\times$ CMS $39 \times B R$ 105). The predicted mean for the composite of size $k=5$, involving all the five selected populations was $4.13 \mathrm{t} / \mathrm{ha}$, which represents $94.1 \% .96 .0 \%$, and $97.9 \%$ of the best predicted composite of sizes $k=2 . k=3$, and $k=4$, respectively. 


\section{INTRODUÇÃO}

Os solos ácidos constituem cerca de 1,66 milhões de hectares em áreas agricolas do mundo (CIMMYT, 1997). No território brasileiro, os solos sob vegetação de "cerrado" correspondem a cerca de 150 milhões de hectares, ocupando quase totalmente a região Centro-Oeste e partes das regiões Norte, Nordeste e Sudeste (EMBRAPA, 1978). A natureza tipicamente ácida destes solos, favorece a presença de aluminio na solução do solo e na forma trocável. Coleman \& Thomas (1967) indicaram que em pH igual ou inferior a 5,0, o alumínio trocável torna-se o cátion dominante. Nestes solos, em sua maioria, temse valor absoluto de alumínio considerado médio (menor que $10 \mathrm{mmol} / \mathrm{dm}^{3}$ ), porém seu valor relativo (saturação de alumínio) encontra-se acima de $40 \%$, valor considerado prejudicial às plantas cultivadas (Kamprath, 1970).

Além do aspecto acidez, os solos sob cerrado apresentam teores de cálcio, magnésio, potássio e fósforo extremamente baixos, sendo limitantes ao desenvolvimento das plantas em condições naturais. A capacidade de troca catiônica (CTC) é baixa, devido ao alto grau de intemperização destes solos, com predominância de argila de baixa atividade e a matéria orgânica (principal responsável pela formação de cargas negativas e troca de cátions nestes solos) em condições naturais apresenta pouca atividade (Lopes, 1983).

A acidez dos solos, associada a baixa fertilidade, prejudica o desenvolvimento das plantas por fatores como deficiencias nutricionais e/ou toxicidade causada por metais pesados. Destes fatores, destaca-se a toxidez causada pelo alumínio, a ponto de restringir o desenvolvimento radicular em camadas subsuperficiais, decrescendo a tolerância à seca e a absorção de nutrientes.

Dentre as estratégias para o manejo dos solos ácidos, têm-se indicado a aplicação de corretivos e/ou melhoramento genético. Com o melhoramento genético busca-se 0 desenvolvimento de cultivares com maior adaptação à condição de acidez. Ressalta-se entretanto, a complexidade da adaptação a solo ácido, envolvendo características 
intrínsicas de cada genótipo com propriedades de solo, de natureza física e química, além da influência de condições climáticas que alteram o regime hídrico no perfil do solo.

Inúmeros estudos relatam a presença de variabilidade genética quanto a adaptação a solos ácidos (Bahia Filho et al., 1976; Naspolini Filho et al., 1981; Borrero et al., 1995; Salazar et al., 1997) sendo este um aspecto principal na identificação de germoplasma adaptado e na obtenção de progressos genéticos com a seleção.

A identificação de germoplasma com adaptação às condições de solo ácido e a verificação do potencial genético é um primeiro passo na condução de um programa de melhoramento voltado para solos ácidos. Com o intuito de avaliar o germoplasma disponivel no banco de germoplasma do Departamento de Genética da ESALQ/USP, o presente estudo teve como objetivos identificar germoplasma com adaptação a solo ácido e com tolerância ao alumínio e, posteriormente, verificar o potencial deste germoplasma para sintese de compostos com adaptação a solo ácido. 


\section{REVISÃO DE LITERATURA}

\subsection{Solos ácidos e efeitos no desenvolvimento de plantas de milho}

Os solos ácidos constituem cerca 1,66 milhões de hectares em áreas agrícolas do mundo e aproximadamente $43 \%$ dos solos tropicais são classificados como ácidos. Também são considerados ácidos, $64 \%$ dos solos tropicais da América do Sul, $38 \%$ dos solos tropicais da Ásia, $27 \%$ dos solos tropicais da África e $10 \%$ dos solos da América Central (CIMMYT, 1997).

Um solo é considerado ácido quando seu pH é abaixo de 7,0 (Coleman \& Thomas, 1967). A acidez do solo envolve aspectos de intensidade e de quantidade. Uma parte do hidrogênio do solo se encontra na fase líquida (solução do solo) e está em equilibrio com aqueles que estão na fase sólida (colóides do solo). A atividade, ou seja, a concentração efetiva de ion hidrogênio da solução do solo, comumente expressa em pH, é o fator intensidade da acidez do solo. A quantidade de hidrogênio que um solo pode liberar durante a neutralização da sua acidez é o fator quantidade. Assim, a acidez do solo pode ser dividida em acidez ativa (fator intensidade) e acidez potencial (fator quantidade), e esta, por sua vez, em acidez de troca e acidez não trocável. $A$ acidez de troca refere-se aos ions $\mathrm{H}^{+}$e $\mathrm{Al}^{3+}$ trocáveis, os quais estão retidos nos colóides por forças eletrostáticas. A acidez não trocável deve-se ao hidrogênio de ligação covalente, associado aos colóides com carga negativa variável e aos polimeros de alumínio (Kinjo, 1983).

Quanto à acidez de troca, Raij (1981) comentou que, erroneamente, o Al é muitas vezes responsabilizado pela acidez dos solos, principalmente os tropicais. Ocorre nos solos diversos minerais que contêm apreciáveis teores de alumínio, principalmente os minerais de argila e óxidos de Al. Em condições de acidez elevada o Al surge em solução, na forma de cátion $\mathrm{Al}^{3+}$, em conseqüência da dissolução desses minerais, 
conforme a reação: $\mathrm{AL}(\mathrm{OH})_{3}+3 \mathrm{H}^{+}$-..--- $\mathrm{Al}^{3+}+3 \mathrm{H}_{2} \mathrm{O}$. A acidez extrema de solos promove o aparecimento do Al em solução, que passa a ser um cátion trocável.

Solos ácidos, em termos de acidez ativa e acidez trocável, apresentam seus sítios de troca ocupados por ions $\mathrm{H}^{+}$e $\mathrm{Al}^{+3}$ e portanto, quanto maior a concentração desses ions menor a soma de bases trocáveis ( $\mathrm{Ca}, \mathrm{Mg}, \mathrm{K}$ e $\mathrm{Na}$ ) ocupando as cargas negativas dos colóides do solo. Com a prática da calagem, atua-se em termos de acidez ativa e acidez trocável, neutralizando-se $\circ \mathrm{H}^{+}$dissociado e $\circ \mathrm{H}^{+}$e $\mathrm{Al}^{+3}$ que ocupam as cargas negativas. Com niveis de $\mathrm{pH}$ superiores a 5,6 estima-se que $\circ \mathrm{Al}^{+3}$ seja totalmente neutralizado e consequentemente, a percentagem de saturação de Al da capacidade de troca de cátions (CTC) efetiva deve ser próxima de zero. Assim a prática da calagem, além insolubilizar o Al na forma de hidróxido, libera as cargas negativas dos colóides para serem ocupadas por $\mathrm{Ca}$ e $\mathrm{Mg}$ trocáveis, elementos essenciais ao desenvolvimento das plantas (Raij, 1981; Lopes, 1989).

No território brasileiro, os solos sob vegetação de cerrado, de natureza ácida, correspondem a cerca de 150 milhões de hectares, aproximadamente $25 \%$ de sua área, ocupando quase totalmente a região Centro-Oeste e partes das regiões Norte, Nordeste e Sudeste (EMBRAPA, 1978). As principais unidades de solos que ocorrem na região dos "cerrados" são os Latossolos, ocupando cerca de $56 \%$ do total, seguindo-se, cerca de $20 \%$ de Areias Quartzosas, 10\% de Lateritas Hidromórficas, 9\% de Litossolos e, em menores percentagens, os Podzólicos (Lopes, 1983).

Os solos sob cerrado são tipicamente ácidos, o que favorece a presença de Al na solução do solo e na forma trocável em concentrações tóxicas. Coleman \& Thomas (1967) indicaramm que em pH igual ou inferior a 5,0 ○ Al trocável torna-se o cátion dominante. Nestes solos, em sua maioria, tem-se valor absoluto de Al considerado médio (menor que $10 \mathrm{mmol}_{\mathrm{c}} / \mathrm{dm}^{3}$ ), porém seu valor relativo (saturação de alumínio) encontra-se acima de $40 \%$, valor considerado prejudicial às plantas cultivadas (Kamprath, 1970).

Tipos de vegetação genericamente chamados de cerrado, também conhecidos como campo sujo, campos cerrados e cerradão, estão relacionados com várias características de solo. A vegetação é tanto mais pobre (campo sujo) quanto maior o grau de saturação em Al e, correspondentemente, menores os teores de potássio, calcio e magnésio (Malavolta \& Kliemann, 1985). 
Olmos \& Camargo (1975) enfatizaram a distribuição e os efeitos prejudiciais do Al nas camadas subsuperficiais do solo, abaixo de 15 a $20 \mathrm{~cm}$. A ocorrência de Al em horizontes subsuperficiais nos solos brasileiros é quase generalizada, mostrando-se atenuada no Nordeste semi-árido. Em virtude das dificuldades agronômicas e econômicas para correção da acidez em maiores profundidades do solo, esta toxidez constitui-se numa condição quase permanente em relação a que ocorre na camada arável.

Além do aspecto acidez, os solos sob cerrado apresentam teores de $\mathrm{Ca}, \mathrm{Mg}, \mathrm{K} \mathrm{e}$ fósforo $(P)$ extremamente baixos, sendo limitantes ao desenvolvimento das plantas em condições naturais. A CTC é baixa devido ao alto grau de intemperização destes solos com predominância de argila de baixa atividade e a matéria orgânica (principal responsável pela formação de cargas negativas e troca de cátions nestes solos) em condições naturais apresenta pouca atividade (Lopes, 1983). A alta capacidade de fixação de $P$, aliada a valores extremamente baixos de $P$ solúvel, tem sido considerada uma das mais severas limitações dos solos sob cerrado para atividades agrícolas.

A condição de acidez do solo com freqüência está associada a disponibilidade de elementos tóxicos, e nestes geralmente tem-se a restrição de nutrientes (Raij, 1981; Kinjo, 1983). Esta condição, por fenômenos diversos, proporciona a redução no crescimento e desenvolvimento das plantas, em parte aérea e raiz, e conseqüentemente sua produção (Lutz et al., 1971; Rhue \& Grogan, 1977; Magalhães \& Silva, 1987).

As deficiências nutricionais resultam de um número de condições dentre as quais a quantidade e disponibilidade de elementos no solo, a forma pela qual o elemento ocorre, os processos para que ele se torne disponivel para planta, o conteúdo na solução do solo e o pH do solo. A caracterização da deficiência é possivel através de sintomas, mudanças perceptiveis em estruturas conhecidas, aparência ou funções (Hale \& Orcut, 1987).

Dentre as possibilidades de toxicidade, destaca-se a toxidez causada pelo alumínio, em nivel de restringir o desenvolvimento radicular em camadas subsuperficiais, decrescendo a tolerância à seca e a absorção de nutrientes (Olmos \& Camargo, 1975; Foy et al., 1978; Ritchie, 1989). O cátion Al, já em 1918, foi relacionado ao retardamento no desenvolvimento de raizes de cevada e arroz em solos ácidos (Hartwell \& Pember, 1918 citados por Roy et al., 1988). A toxicidade de Al inibindo o desenvolvimento 
radicular é o sintoma mais facilmente reconhecido, sendo amplamente aceito como medida de estresse em plantas (Delhaize \& Ryan, 1995).

As raizes de plantas estressadas por $A l$ apresentam características como o início de emissão de raizes próximas ao ponto de crescimento da raiz principal e a inibição do crescimento de raizes laterais. As raizes tornam-se curtas, grossas e quebradiças $e$, quase sempre de coloração amarronzada e, em consequência, o sistema radicular fica desprovido de raizes finas, reduzido em tamanho e com aparência de corais (Foy, 1974; Foy et al., 1978; Foy, 1984, 1992; Malavolta et al., 1989).

Os efeitos fitotóxicos do Al ocasionam a inibição da elongação e divisão celular, a diminuição da taxa de respiração, interferências em reações enzimáticas que governam a deposição de polissacarídeos nas paredes celulares, aumento da rigidez celular e a alteração na absorção, transporte e uso de diversos nutrientes, notadamente $\mathrm{Ca}, \mathrm{Mg}$ e $\mathrm{P}$ e água (Foy et al., 1978; Furlani, 1983; Kochian, 1995).

Parte do Al na raiz liga-se as substâncias pécticas da parede celular, enquanto outra parte penetra no protoplasma e se combina com os ácidos nucleicos e ácidos solúveis de fosfato (Wagatsuma, 1983). Um dos primeiros efeitos do Al é a desorganização da membrana plasmática. Freqüentemente, as células da coifa da raiz tornam-se vacuoladas, com interrupção da função do aparelho de Golgi e do desenvolvimento de plastídeos; sofrem alterações na estrutura nuclear e perdas de citoplasma e finalmente, a desintegração. As células da epiderme, da endoderme e corticais afetadas por Al, rapidamente se autolizam, tornando-se inchadas e desorganizadas. As regiões meristemáticas das raizes primárias e laterais desorganizam-se, tornando difícil a distinção entre coifa e os elementos vasculares (Foy, 1988; Taylor, 1988).

Na parte aérea das plantas, muitas vezes, os sintomas de toxidez de Al não são claramente diagnosticados, sendo, entretanto, mais facilmente observados na fase inicial de desenvolvimento da planta (Foy, 1984). Em algumas plantas os sintomas foliares assemelham-se aqueles de deficiencia de fósforo, com desenvolvimento reduzido, folhas mais velhas pequenas, verde-escuras e com bordas de cor púrpura, podendo ocorrer também nos colmos, e amarelecimento e morte das pontas das folhas. Em outras plantas, a toxicidade de Al aparece como uma indução de deficiência ou redução no transporte de cálcio. As folhas jovens mostram-se enrroladas ou onduladas e ocorre o colapso do ponto de crescimento (Foy et al., 1978). 
Diversas espécies nativas e cultivadas exibem variabilidade nas suas respostas a toxicidade ao Al, com possibilidades de ser explorada no melhoramento de plantas. Os mecanismos que facilitam a exclusão do Al nas células da raiz. conforme Kochian (1995), conferem a resistência. A tolerância é referida aos mecanismos que permitem a planta tolerar o Al no interior da célula, promovendo sua destoxicidade.

Dentre os mecanismos de exclusão, um dos mais considerados envolve a liberação de ácidos orgânicos pelo ápice da raiz. Os ácidos orgânicos, tais como malato em trigo e citrato em milho, quando liberados promovem a quelatização do Al, ou seja, a fomação de complexos orgânicos solúveis com o Al, protegendo o ápice da raiz (Foy et al., 1978; Roy et al., 1988; Kochian, 1995). Em certas cultivares de trigo, cevada, arroz e milho, em soluções nutritivas, a exclusão do $\mathrm{Al}$ foi atribuida ao aumento do $\mathrm{pH}$ da rizosfera, tendo-se decréscimo da solubilidade e toxicidade do Al (Foy et al., 1978).

A parede celular de células da raiz também tem sido apontada por sua função na imobilização do Al. Segundo essa hipótese, essas células possuem poros cobertos por cargas negativas e podem ser um ponto de ligação e imobilização do Al, impedindo a associação com a membrana plasmática ou a entrada no citoplasma (Kochian, 1995). Outras possibilidades de exclusão do $\mathrm{Al}$, ou resistência externa ao $\mathrm{Al}$, são o efluxo do $\mathrm{Al}$ através da membrana plasmática; a exudação de fosfato e a permeabilidade seletiva da membrana plasmática (Taylor, 1995).

Mecanismos de destoxificação interna têm sido verificados em algumas espécies. No citoplasma, esses mecanismos constituem a tolerância de plantas ao Al, incluindo-se a quelatização no citossol, a compartimentalização em vacuolos e a presença e atividade de enzimas de tolerância ao Al (Taylor, 1995). A indução da tolerância a partir de compostos ligantes ao $\mathrm{Al}$, como peptídeos de baixo peso molecular, tem recebido credibilidade, entretanto, poucas evidências suportam essa possibilidade (Kochian, 1995).

\subsection{Herança, variabilidade genética, heterose e capacidade combinatória em caracteres em solos ácidos}

A possibilidade da produção de milho em solos ácidos tem proporcionado grande ênfase aos programas de melhoramento genético visando ao desenvolvimento de materiais com adaptação. De modo a orientar esses programas, alguns estudos buscam 
informações sobre o controle genético, variabilidade genética e efeitos genéticos em cruzamentos em caracteres relacionados à adaptação a fatores ou ao complexo de fatores envolvidos em solos ácidos.

Sendo o Al um dos fatores mais restritivos em solos ácidos, muitos estudos reportam resultados quanto a características indicativas da adaptação a esse elemento. Entretanto, diversos elementos, incluindo-se $\circ \mathrm{Al}$, e as interações entre esses, constituem um complexo que provoca toxicidades e deficiências, promovendo baixas produtividades em solos ácidos. Os resultados apresentados a seguir referem-se, em alguns casos, à adaptação ao complexo acidez do solo, e em outros, aos efeitos especificos do Al.

Rhue \& Grogan (1977) e Rhue et al. (1978), empregando linhagens de milho, relacionaram a tolerância à toxidez de $\mathrm{Al}$, em solução nutritiva, a ação de um loco e efeito alélico dominante, com possibilidade da ocorrência de alelos múltiplos. Também concluiram quanto a ausência de efeitos de genes citoplasmáticos na manifestação da caracteristica. Resultados semelhantes foram obtidos por Silva (1979), o qual atribuiu a tolerância a um gene com efeito de dominância para a tolerância, porém com a possibilidade de efeitos de genes modificadores.

Considerando o crescimento relativo de raíz seminal em milho, em gerações a partir de linhagens contrastantes em tolerância em solução nutritiva, Magnavaca (1982) verificou que os efeitos genéticos aditivos foram responsáveis por maior parte da variação genética. Os efeitos genéticos de dominância foram não significativos apenas em um, entre quatro grupos de gerações estudados. Os efeitos epistáticos foram significativos em dois grupos de gerações, porém de baixas magnitudes em relação aos efeitos aditivos e de dominância. Entretanto, em dois grupos de gerações a partir de linhagens sensiveis ao $\mathrm{Al}$, foi constatado que os efeitos de dominância explicaram a maior parte da variação genética, seguidos por efeitos epistáticos e efeitos aditivos.

Analisando a variação entre plantas $F_{2}$, Magnavaca (1982) constatou, para as variáveis comprimento relativo de raiz seminal e comprimento líquido de raiz seminal, distribuições de freqüência com forma contínua e unimodal, próprias de caracteres herdados quantitativamente, com alta frequência de plantas sensiveis.

Miranda et al. (1984) atribuiram a tolerância ao Al a ação de dois genes complementares, ligados, com efeito alélico dominante para tolerância. Esses efeitos também foram atribuidos à tolerância ao calor. Já Sawazaki \& Furlani (1987), também 
empregando linhagem tolerante de origem Cateto, verificaram a ação de genes menores, predominando efeitos gênicos aditivos.

A partir de versões divergentes da população IAC-Taiúba quanto ao crescimento de radícula em presença de Al, Lima et al. (1992), obtiveram resultados indicativos de um caráter quantitativo e de alta herdabilidade, com efeitos não aditivos apresentando menor importância.

Ceballos et al. (1998) verificaram efeitos aditivos, dominantes e epistáticos na produtividade de grãos em milho de origem tropical, em três ambientes de solo ácido e um ambiente de solo não ácido. No ambiente de solo não ácido, os efeitos de dominância foram predominantes, com aproximademente $81 \%$ da variação total. Nesta condição a epistase apresentou pequena e não significativa influência na expressão dos caracteres. Nos locais com solo ácido a dominância foi de menor importância, destacando-se os efeitos epistáticos, com alta proporção da variabilidade total.

Empregando marcadores moleculares do tipo RFLP ("restriction fragment length polymorphism") no estudo da tolerância da linhagem de milho Cat-100-6 ao Al, a partir de crescimento de raiz seminal, Sibov et al. (1999) indicaram a ação de dois locos. Os dois locos, Alm1 e Alm2, foram mapeados nos braços curtos dos cromossomos 10 e 6 , respectivamente, sendo atribuido ao loco Alm1 a maior parte dos efeitos à tolerância.

Galvão \& Silva (1978) avaliaram progênies da variedade Piranão em vasos contendo solo ácido. Para o peso seco da parte aérea as estimativas da variância genética aditiva foram bastante inferiores as estimativas da variância genética de dominância, com herdabilidade próxima a $28 \%$. Para o peso seco das raízes a estimativa da variância genética aditiva foi negativa, mas não diferente de zero. Devido a predominância da variância genética de dominância os autores sugeriram a utilização de métodos de melhoramento interpopulacionais e a formação de híbridos.

A partir de dois ciclos de seleção divergente para tolerância ao $\mathrm{Al}$, considerando o crescimento liquido de radícula em solução nutritiva, Lima et al. (1992) constataram, em média, mudanças de $5,2 \mathrm{~cm}(26,1 \%)$ no comprimento da radícula, tanto para seleção positiva quanto para seleção negativa. Os efeitos da seleção também foram verificados para rendimento de grãos, altura da planta e altura da espiga, a partir da avaliação em solo ácido, com mudanças médias de 1,17 t/ha, $10 \mathrm{~cm}$ e $3 \mathrm{~cm}$, respectivamente.

Granados et al. (1993), considerando o desempenho produtivo, relataram significativos progressos seletivos na adaptação da população de milho SA-3 a solos 
ácidos. Na média de 11 ambientes de avaliação, para o esquema espiga por fileira modificado, verificaram progresso de $40 \mathrm{~kg} / \mathrm{ha}$ por ciclo $(1,49 \%)$. Com o esquema de famílias de irmãos germanos, o progresso foi de $250 \mathrm{~kg} / \mathrm{ha}$ por ciclo $(8,10 \%)$.

Também empregando a população SA-3, Duque-Vargas et al. (1994), utilizaram o Delineamento I de Comstock \& Robinson (1948) para estudar a variabilidade genética. Nos ambientes de solo ácido, para rendimento de grãos, as estimativas de variância genética aditiva e de variância genética de dominância foram próximas. A estimativa de herdabilidade, para média de famílias de meios irmãos, foi de $36,3 \pm 19,9 \%$. A variância da interação aditiva $x$ ambiente foi o componente mais importante da variância genética.

Borrero et al. (1995) estimaram variâncias genéticas na população de milho SA-4. As progênies foram avaliadas em quatro ambientes de solo ácido e em um ambiente de solo não ácido. Nos ambientes de solo ácido, a variância de dominância predominou sobre a variância aditiva, para rendimento de grãos e dias para florescimento feminino. A variância aditiva foi maior para altura da espiga, indice de espiga e espigas doentes. Em média de familias de meios irmãos, obtiveram herdabilidades de 0,39 $\pm 0,14$ para produtividade; $0,43 \pm 0,14$ para dias para florescimento feminino; 0,66 $\pm 0,13$ para altura da espiga; 0,47 $\pm 0,14$ para indice de espigas e 0,66 $\pm 0,13$ para espigas doentes.

A partir de 363 linhagens de milho, Naspolini Filho et al. (1981) identificaram dez com boa adaptação às condições de solo ácido. Essas dez linhagens selecionadas foram empregadas em esquema de cruzamentos dialélicos, realizando-se avaliações em três niveis de saturação de alumínio no solo. Quatro linhagens apresentaram estimativas positivas de capacidade combinatória para peso de grãos e comportamento estável nos três niveis de calagem. Uma quinta linhagem foi selecionada por apresentar alta CGC no nível zero de calagem (669 kg/ha). Os dez melhores hibridos simples apresentaram um intervalo de variação para produção de 3588 a 2963 kg/ha.

Em cruzamentos dialélicos entre linhagens de origem temperada (Mo17, C103, H84, Cl64, B37, W117, A635 e A554), avaliados quanto ao crescimento relativo de raiz e crescimento líquido de raiz em solução nutritiva, Magnavaca (1982) verificou diferenças significativas entre linhagens, linhagens vs. cruzamentos, capacidade geral de combinação (CGC) e capacidade especifica de combinação (CEC). A variância devida a CGC constituiu a maior parte da variação dos cruzamentos. As linhagens A554, Cl64 e H84 apresentaram estimativas de CGC positivas para crescimento relativo de raiz seminal. Embora contribuindo para a boa "performance" nos cruzamentos em que 
participou, a linhagem A554 apresentou baixo nivel de tolerância ao Al na avaliação "per se". Em termos de CEC, os maiores efeitos foram obtidos para os cruzamentos W117 $x$ A635, C164 × A554 e H84 × A554.

Lopes et al. (1987) avaliaram 13 populações (CMS 30, CMS 36, CMS 200, CMS 14, CMS 04, BR 105, CMS 28, CMS 11, CMS 12, CMS 22, BR 126, CMS 06 e CMS 07) em solução nutritiva com alumínio tóxico. As populações CMS 36, CMS 30 e o híbrido triplo BR 200, materiais que já haviam sido submetidos a seleção em solos ácidos, apresentaram os melhores resultados. Posteriormente, as populações CMS 30, CMS 36, CMS 04, CMS 14 e CMS 13 foram empregadas em cruzamento dialélico, avaliando-se os hibridos e seus reciprocos. As populações CMS 36 e CMS 30 apresentaram estimativas de CGC de 7,16 e 6,39 \%, respectivamente, quanto a percentagem de crescimento relativo de raiz seminal e as demais populações apresentaram estimativas negativas. $O$ efeito de cruzamentos reciprocos foi não significativo, indicando a ausência de efeito materno. Os cruzamentos CMS $14 \times$ CMS 30 e CMS $14 \times$ CMS 30, com estimativas de 9,04 e $5,50 \%$ de crescimento relativo de raiz seminal, respectivamente, apresentaram os maiores efeitos positivos de CEC.

Em cruzamentos dialélicos entre as populações de milho CMS 04, CMS 13, CMS 14, CMS 30 e CMS 36, avaliados para peso de espigas despalhadas em solos sob "cerrado", Eleutério et al. (1988) verificaram o melhor desempenho "per se" para a população CMS 36. As estimativas de CGC, com exceção da população CMS 04, foram positivas, sendo o maior efeito proporcionado por CMS 36. Para CEC, os maiores efeitos foram obtidos nos cruzamentos CMS $04 \times$ CMS 30, CMS $04 \times$ CMS 13, CMS $04 \times$ CMS 36 e CMS $13 \times$ CMS 30.

Pandey et al. (1994) realizaram cruzamentos dialélicos entre oito populações de milho, sendo seis tolerantes a solos ácidos (90SA-3, 90SA-4, 90SA-5, 90SA-6, 90SA-7 e CMS 36) e duas não tolerantes (Tuxpeño e Pool 26). Na média de ambientes, os efeitos de CGC e da interação CGC x ambientes foram altamente significativos para rendimento de grãos, dias para florescimento, altura da espiga e índice de espigas. Os efeitos de CEC foram significativos apenas para indice de espigas. Para rendimento de grãos, foram obtidas estimativas de CGC positivas e significativas para as populações 90 SA-3 (320 kg/ha), 90SA-4 (160 kg/ha) e CMS 36 (130 kg/ha).

Lima et al. (1995), utilizaram oito linhagens de milho em esquema de cruzamentos dialélicos, sendo três linhagens sensiveis (S) e cinco linhagens tolerantes 
(T) ao Al. Nas avaliações de comprimento de radícula, em solução nutritiva, em média, os cruzamentos $\mathrm{S} \times \mathrm{S}$ apresentaram $17,0 \mathrm{~cm}$; os cruzamentos $\mathrm{S} \times \mathrm{T}$ apresentaram 28,1 $\mathrm{cm}$ e os cruzamentos $\mathrm{T} \times \mathrm{T}$ apresentaram $37,8 \mathrm{~cm}$. Os valores observados nos cruzamentos $S \times T$ e $T \times T$ foram característicos de efeitos aditivos de alelos. A linhagem IAC96.4 apresentou o maior efeito de linhagem $(11,49 \mathrm{~cm})$. As maiores estimativas de heterose de linhagens foram 3,49 e 3,09 cm para as linhagens Ip48.5.3 e Ip365.4.1, respectivamente, de origem Cateto. Em avaliações a campo, em solo corrigido para acidez, as linhagens Col2(22) e IAC13.8 apresentaram as maiores estimativas de CGC para rendimento, $681 \mathrm{~kg} / \mathrm{ha}$ e $816 \mathrm{~kg} / \mathrm{ha}$, respectivamente. Os resultados para comprimento de radícula sugeriram que grande parte da variabilidade é de natureza aditiva, embora efeitos não aditivos possam contribuir substancialmente para expressão da característica em cruzamentos. Para rendimento de grãos, os efeitos genéticos não aditivos podem ser uma importante fonte de variação entre cruzamentos.

Salazar et al. (1997) realizaram cruzamentos dialélicos entre oito populações de milho, sendo seis tolerantes (CMS 36, 92SA-3, 92SA-4, 92SA-5, 92SA-6 e 92SA-7) e duas não tolerantes a solos ácidos (Tuxpeño Sequia e ETO Blanco). As populações, os híbridos e seus recíprocos foram avaliados em cinco ambientes com solos ácidos, com diferentes niveis de $\mathrm{Al}$, fósforo e $\mathrm{pH}$. Os efeitos de heterose de populações e cruzamentos reciprocos foram não significativos. A população $92 S A-3$ apresentou a maior estimativa positiva e significativa de efeito de população (620 kg/ha), seguida pelas populações CMS 36 e $92 \mathrm{SA}-5 \mathrm{com}$ estimativas de $330 \mathrm{~kg} / \mathrm{ha}$ e $210 \mathrm{~kg} / \mathrm{ha}$, respectivamente. Os cruzamentos CMS $36 \times$ Tuxpeño Sequía, ETO Blanco x 92SA-5 e ETO Blanco $\times$ 92SA-4, apresentaram os maiores efeitos positivos de heterose especifica, $210 \mathrm{~kg} / \mathrm{ha}, 190 \mathrm{~kg} / \mathrm{ha}$ e $190 \mathrm{~kg} / \mathrm{ha}$, respectivamente, porém não significativos.

\subsection{Cruzamentos dialélicos e "top-crosses" no melhoramento de milho}

A metodologia de cruzamentos dialélicos, amplamente utilizada no melhoramento genético de plantas, refere-se ao intercruzamento entre $n$ progenitores, dois a dois, produzindo $n^{2}$ combinações híbridas, que correspondem aos $n$ progenitores, $n(n-1) / 2$ híbridos e $n(n-1) / 2$ híbridos reciprocos, perfazendo uma tabela dialélica completa.

Sprague \& Tatum (1942) apresentaram conceituações dos termos capacidade geral e específica de combinação, muito utilizados no melhoramento de plantas e em 
especial nos cruzamentos dialélicos. Para a capacidade geral de combinação (CGC) referiram-se como a "performance média" de uma linhagem em combinações híbridas, relacionando-a a efeitos genéticos aditivos. A capacidade especifica de combinação (CEC) foi empregada para combinações híbridas relativamente melhores ou piores do que o esperado com base na performance média das linhagens envolvidas, sendo relacionada a efeitos genéticos não aditivos (dominância e epistasia).

A metodologia originalmente proposta por Jinks \& Hayman (1953) e ampliada em outros estudos, possibilita a análise da variância da tabela dialélica testando-se a presença de efeitos genéticos aditivos e dominantes. Este procedimento permite a estimação de componentes da variância genética, de parâmetros como o número mínimo de genes envolvidos no controle do caráter, herdabilidade, grau médio de dominância, além de outros de natureza mais básica e teórica, como proporção de alelos positivos e negativos nas linhagens, razão entre o número total de genes dominantes e recessivos nas linhagens e grau de dominância por loco. Embora proporcione grande número de informações genéticas sobre as linhagens progenitoras e seus cruzamentos, as condições básicas do modelo que fundamentaram o método de Jinks \& Hayman são bastante rigorosas, como segregação diplóide, ausência de efeitos epistáticos, ausência de alelos multiplos, homozigose dos progenitores e distribuição independente dos alelos nas linhagens progenitoras (Vencovsky, 1970; Ramalho et al., 1993).

Griffing (1956) propôs metodologias de análise de tabelas dialélicas considerando a natureza de amostragem do material experimental, ou seja, para efeitos fixos (modelo l) e aleatórios (modelo II). Conforme os tratamentos componentes, apresentou quatro métodos de análise: Método 1, que inclui os progenitores, híbridos e híbridos recíprocos; Método 2, que inclui os progenitores e híbridos; Método 3, incluindo somente híbridos e híbridos recíprocos; e o Método 4, que só inclui os híbridos. Os testes de significância para a capacidade de combinação, a estimação de efeitos e a identificação de combinações de alto rendimento, são as principais informações no modelo fixo. No modelo aleatório, têm-se a possibilidade de estimar propriedades genéticas da população amostrada, tais como componentes da variância genética, herdabilidade e grau médio de dominância.

Considerando que o aumento no número de linhagens progenitoras $(n)$ leva a um aumento significativo no número de híbridos possíveis $n(n-1) / 2$, podendo inviabilizar 0 estudo em sua parte experimental, Kempthome \& Cumow (1961) propuseram a 
metodologia de cruzamentos dialélicos parciais. Nesta proposição, apenas uma porção dos cruzamentos possiveis entre $n$ linhagens progenitoras é realizado, tendo-se um total de $n s / 2$ cruzamentos, sendo $n$ o número de linhagens progenitoras e $s$ o número de cruzamentos em que participa cada uma.

Considerando a importância do emprego de variedades de polinização livre no melhoramento genético do milho, Gardner (1965) apresentou teoria e procedimento para o estudo de médias de um grupo fixo de variedades e de seus cruzamentos. Segundo o autor, as médias de populações proporcionam importantes informações genéticas. são facilmente estimáveis, com maior precisão que variâncias e as populações requeridas são facilmente obtidas.

Em Gardner \& Eberhart (1966) são apresentados três formas de análises. de acordo com os efeitos proporcionados pelos tipos de populações envolvidas. Na análise I, a partir das médias de variedades, de variedades autofecundadas, dos hibridos de variedades, dos hibridos autofecundados e multiplicados por cruzamento ao acaso. são testados efeitos aditivos, de dominância e de heterose, com o desdobramento desse último em heterose média, heterose varietal e heterose específica. Na análise II, compreendendo somente o grupo de variedades e seus hibridos, são testados os efeitos de variedades, onde estão confundidos efeitos genéticos aditivos e de dominância, e os efeitos de heterose, com a mesma composição apresentada na análise I. A análise III refere-se a avaliação apenas dos cruzamentos entre um grupo de variedades. Nesta situação, o modelo de cruzamentos é decomposto em efeitos de capacidade geral e específica de combinação.

Eberhart \& Gardner (1966) apresentaram modelos genéticos com efeitos epistáticos do tipo aditivo $x$ aditivo, além dos efeitos aditivos e de dominância, contemplando também a condição de alelismo múltiplo. Considerando a análise II, Gardner (1967) apresentou expressões para estimação dos parâmetros genéticos do modelo e para cálculo das somas de quadrados

Miranda Filho \& Geraldi (1984) apresentaram uma adaptação ao modelo de Gardner \& Eberhart (1966), na qual dois grupos fixos de variedades e seus cruzamentos são empregados. Com essa metodologia de cruzamentos dialélicos parciais, grupos de materiais com características distintas e de importância para o melhoramento, como grãos tipo dente vs. duro, porte alto vs. baixo, material adaptado vs. exótico, entre outras 
possibilidades, podem ser estudados quanto aos seus comportamentos em cruzamentos.

Em Geraldi \& Miranda Filho (1988), também para dois grupos distintos de variedades e seus cruzamentos, foram propostas duas alternativas para análise da capacidade combinatória. Um modelo alternativo refere-se a uma adaptação ao método 2, de Griffing (1956), tendo sido o outro desenvolvido com base nas proposições de Sprague \& Tatum (1942), que, em última análise é também uma adaptação do Método 4 de Griffing (1956).

Considerando o efeito de cruzamentos reciprocos em análises dialélicas, com a participação das variedades genitoras, Miranda Filho (1995) propõe um modelo, adaptado ao modelo de Gardner \& Eberhart (1966), com a presença do efeito recíproco.

Em Miranda Filho \& Chaves (1996), a metodologia original de Gardner \& Eberhart (1966) é empregada utilizando-se variedades e gerações $F_{2}$ do cruzamento entre essas. Neste estudo, considerando espécies onde se tem dificuldade de produção de sementes $F_{1}$ para emprego em avaliações, os autores apresentaram procedimentos de análise e estimação de efeitos com base em médias de gerações $F_{2}$. Com progênies de duas populações distintas, Miranda Filho \& Vencovsky (1999) apresentaram a metodologia de cruzamentos dialélicos parciais circulantes, ao nível interpopulacional. Nesta metodolgia, prevê-se o emprego de duas populações com uma amostra aleatória de $n$ linhagens ou genótipos de cada uma. São realizados ns cruzamentos, sendo s o número de vezes que cada linhagem é cruzada com linhagens da população contrastante. Os efeitos de capacidade geral de combinação são definidos para cada população, independentemente, e a capacidade especifica de combinação é definida ao nível interpopulacional.

Davis (1927), citado em Hallauer \& Miranda Filho (1995), sugeriu o uso do procedimento "top cross", um tipo de teste de progênie, para fins de avaliação da capacidade combinatória de linhagens endogâmicas em um programa de híbridos de milho. Este procedimento passou a ser amplamente utilizado em programas de desenvolvimento de híbridos, e posteriormente, passou a ser empregado em esquemas de seleção recorrente. Basicamente, os "top crosses" ou "test crosses" permitem avaliar a capacidade combinatória de linhagens em um programa de milho híbrido, ou selecionar genótipos de uma população com base na "performance" das suas progênies em cruzamento. 
Considerando populações de milho, Chaves \& Miranda Filho (1997) sugeriram o emprego de cruzamentos "topcrosses" como alternativa aos cruzamentos dialélicos para fins de estimação de médias de compostos de variedades. Segundo essa proposição, o testador é representado por uma mistura de pólen de todas as populações que constituem o grupo a ser avaliado em "topcrosses". Na análise das variedades e "topcrosses" empregou-se o modelo 3 de Gardner \& Eberhart (1966), sem a presença de efeito de heterose especifica, porém permitindo testar-se os demais efeitos do modelo. $O$ método foi designado de "top-cross" intragrupo. Moreira Junior (1995) e Gorgulho (1997) obtiveram resultados experimentais empregando o delineamento "top-cross" intergrupos, segundo o qual, dois grupos de variedades são cruzadas reciprocamente, sendo cada grupo o testador das variedades do grupo contrastante.

\subsection{Predição de médias de compostos de variedades}

Composto é um tipo de população formada pelo intercruzamento e recombinação de um grupo fixo de variedades de polinização livre. O seu emprego no melhoramento genético decorre da possibilidade de agregar caracteres desejáveis em um único material, além de ampliar a variabilidade genética, decorrente da combinação de materiais com origens diversas. Na formação de compostos, um aspecto de grande importância é a possibilidade da predição de seus comportamentos, para as diversas caracteristicas de interesse.

Wright (1922), citado em Sprague (1977), apresentou um dos primeiros trabalhos a respeito da predição de médias em populações originadas por intercruzamento de linhagens homozigóticas, denominadas de "variedades sintéticas" (Hayes e Garber, 1919 citados por Allard, 1960). Com o advento do híbrido duplo, tornou-se impraticável a obtenção de todos os híbridos duplos possiveis a partir de um conjunto de linhagens endogâmicas. Em decorrência, Jenkins (1934) desenvolveu quatro metodologias de predição de médias de hibridos duplos. A predição com base nas médias dos quatro híbridos simples não genitores, entre as quatro linhagens, e que considera efeitos genéticos aditivos e não aditivos, mostrou-se mais eficaz.

Com a realização de cruzamentos dialélicos entre um conjunto de variedades e a análise a partir dos modelos propostos por Gardner \& Eberhart (1966), tornou-se possivel a predição de médias de compostos de variedades. Eberhart et al. (1967) 
propuzeram que a expressão $\bar{C}_{0}=\bar{C}-(1 / n)(\bar{C}-\bar{V})$, sendo $\bar{C}$ e $\bar{V}$ as médias dos grupos de cruzamentos e das $n$ variedades genitoras, respectivamente, poderia ser utilizada na predição de compostos de variedades. Vencovsky \& Vello (1969) indicaram essa expressão para qualquer predição de síntese, tendo-se igual proporção na participação dos genitores. Vencovsky (1970) propôs uma fórmula de predição para situações onde se têm diferentes proporções de contribuição e em Vencovsky et al. (1973) foi sugerida uma fórmula geral para predição de médias de qualquer população não endogâmica obtida através de cruzamentos controlados entre genitores em equilibrio genético.

Vencovsky \& Miranda Filho (1972) apresentaram a expressão $N_{C O}=2^{n}-(n+1)$, para determinação do número de diferentes compostos possíveis, assumindo-se igual contribuição de progenitores. Considerando-se este aspecto, Miranda Filho \& Chaves (1991) apresentaram dois critérios auxiliares para seleção entre variedades na predição de compostos, quando o número de variedades genitoras é elevado. Uma possibilidade é através da média e da variância de cada grupo de compostos de mesmo tamanho $k$, proporcionando uma comparação entre e dentro de grupos de compostos. Outra possibilidade refere-se a contribuição de variedades genitoras para média do composto. Neste caso, com base em estimativas de efeitos de variedades $\left(v_{\mathrm{j}}\right)$ e heterose de variedade $\left(h_{\mathrm{j}}\right)$, obtem-se o indice, $l_{\mathrm{j}}=(1 / k) v_{\mathrm{j}}+\left[2(k-1) / \mathrm{k}^{2}\right] \mathrm{h}_{\mathrm{j}}$, 0 qual possibilita a seleção entre as variedades genitoras para formação de compostos de tamanho $\mathrm{k}$.

Chaves \& Miranda Filho (1997) sugeriram a predição de média de compostos sem a realização de cruzamentos dialélicos. Considerando que as informações referentes a cruzamentos específicos são negligenciáveis para predição da média de compostos, propuzeram a obtenção de estimativas de efeitos de variedades $\left(v_{j}\right)$ e de heterose varietal $\left(h_{j}\right)$ a partir de cruzamentos "topcrosses", onde o conjunto de variedades genitoras é empregado como testador de cada variedade em estudo, obtendo-se um modelo de análise reduzido, equivalente ao modelo 3 de Gardner \& Eberhart (1966). 


\subsection{Germoplasma de milho}

Os processos de seleção natural e artificial, em diferentes condições ambientais, proporcionaram à espécie Zea mays L. diferenças morfológicas e fisiológicas que conferem adaptação a uma extensa área geográfica, sendo o milho cultivado, atualmente, desde $58^{\circ}$ de latitude Norte até $40^{\circ}$ de latitude Sul, através das regiões temperadas, tropicais e subtropicais. O cultivo do milho no Canadá, norte da Europa, Rússia, Austrália, África do Sul, Argentina, entre outras condições, deve-se a processos de adaptação para diferentes nichos ecológicos. Na região Andina, o milho desenvolvese desde condições ao nivel do mar até em altitudes superiores a 3 mil metros (Hallauer \& Miranda Filho, 1988).

Aspectos como necessidades de alimentos, combustivel, fibras, costumes indigenas e o desenvolvimento da civilização, com migrações e diferentes culturas populares, também contribuíram para a diversidade de germoplasma. Adicionalmente, a polinização livre proporcionou o intercâmbio de genes, levando a novas combinações. Essa diversidade genética é verificada em acentuadas diferenças fenotípicas, como tipo da planta, tipo da espiga, tipo do pendão, maturação, entre muitas outras características (Goodman, 1987; Hallauer \& Miranda Filho, 1995).

Diversos esforços têm sido realizados no sentido de coletar germoplasma, preservá-losr, classificá-los, além de realizar estudos que contemplem aspectos evolutivos da espécie Zea mays L. e da civilização humana, aspectos de utilização da diversidade para fins de melhoramento genético e da composição racial (Goodman \& Brown, 1988). Anderson \& Cutler (1942) conceituaram raças como "grupo de indivíduos relacionados com suficiente caracteristicas em comum as quais permitem 0 reconhecimento como grupo". Em termos genéticos, refere-se a "um grupo com significante número de genes em comum". Como resultados desses esforços, raças de milho de diversas origens, e suas relações, foram descritas. Goodman \& Brown (1988) e Hallauer \& Miranda Filho (1988) apresentam coletâneas de informações de complexos raciais do México, América Central, Caribe, América do Sul, Estados Unidos e Europa, contemplando principalmente o Hemisfério Ocidental.

Entre os complexos raciais amplamente disseminados, os dentados mexicanos, como "Tuxpeño", "Vandeño", "Celaya", entre outros, são considerados os tipos 
agronomicamente mais importantes. Da disseminação destes, originaram-se os milhos dentados do Sul dos Estados Unidos e mais tarde os dentados do "Corn Belt", os "Tusóns" e os milhos duros do Caribe, compreendendo os "Coastal Tropical Flints", "Comuns", "Costeños", "Catetos Nortistas". Os milhos dentados mexicanos, assim como os dos Estados Unidos e os tipos do Caribe, têm sido amplamente utilizados em programas de melhoramento do Brasil, Chile e Argentina. Outros complexos raciais bastante disseminados compreende os milhos "Catetos" do Sul do Brasil, Uruguai e Argentina, bem como os milhos duros, cristalinos amiláceos, do Norte dos Estados Unidos e Sul do Canadá. Esses complexos de grãos duros se disseminaram pelas regiões temperadas onde este tipo de grão é preferido (Goodman \& Smith, 1987).

Goodman (1978) destacou os complexos raciais de maior importância para o melhoramento genético do milho: os dentados mexicanos, compreendendo as raças e populações "Tuxpeño", "Vandeño", "Tepecintle", "Zapalote Chico", "Zapalote Grande" e "Celaya"; os dentados do "Com Belt", compreendendo os "Reid", "Lancaster" e "Krug"; os dentados do Caribe, compreendendo os "Tusóns"; os cristalinos do Caribe, compreendendo os "Coastal Tropical Flints", "Comuns" e "Costeños"; os "Catetos" e os cristalinos amiláceos do Norte dos Estados Unidos e Sul do Canadá. Os dentados mexicanos, dentados do Caribe e cristalinos do Caribe com importância para regiões tropicais, os dentados do "Com Belt" e os cristalinos e amiláceos do Norte do Estados Unidos e Sul do Canadá com importância para regiões temperadas, e os "Catetos" com importância tanto para condições tropicais quanto temperadas.

Os recursos genéticos de milho, representados por germoplasma de coleta, coleções de trabalho, cultivares melhoradas e linhagens, constituem-se na mais importante fonte de variação genética para o melhoramento. Ao nivel mundial, os bancos de germoplasma conservam aproximadamente 100.000 acessos de milho (Chang, 1992). Atualmente, o banco de germoplasma do Centro Internacional de Melhoramento de Milho e Trigo (CIMMYT) mantém cerca de 13.200 acessos, computando-se conjuntamente as coleções de base e ativa, sendo que novas introduções são feitas periodicamente (Taba, 1995). De acordo com as projeções para as duas próximas décadas esse número poderá atingir 30.000 acessos. No Brasil, a coleção de base tem 2.884 acessos, enquanto a coleção ativa (BAG-Milho) conta com 2.396 acessos. Recentemente, foram repatriados 1.374 acessos que estavam sendo mantidos pelo banco de germoplasma do CIMMYT, 
os quais, oportunamente, serão incorporados ao sistema de conservação a médio e longo prazos (Nass et al. 2000).

Os recursos genéticos de milho, presentes nos bancos de germoplasma, podem ser utilizados para fins de melhoramento de diversas formas. Crossa et al. (1990), sugere o uso de coleções para o desenvolvimento de novas populações heteróticas para melhoramento através de seleção recorrente recíproca, para o desenvolvimento de linhagens e híbridos considerando suas capacidades combinatórias, para introgressão em populações adaptadas e para o desenvolvimento de variedades superiores, através de seleção recorrente intrapopulacional.

Uma importante estratégia de utilização da diversidade genética em milho é através da introdução de germoplasma exótico. Germoplasma exótico, em programas de melhoramento aplicado, referem-se a todos os materiais que não apresentam utilidade imediata sem uma seleção prévia para adaptação em uma determinada área (Hallauer \& Miranda Filho, 1988). Neste sentido, germoplasma exótico pode referir-se a raças, populações, hibridos, linhagens, etc., desde que apresentando origem diferente daquela onde se está introduzindo, necessitando de adaptação a nova condição.

Mesmo havendo um grande número de raças de milho no Brasil e outros países da América do Sul, a introgressão de germoplasma exótico pode proporcionar importantes avanços em programas de melhoramento em áreas tropicais da América do Sul (Miranda Filho, 1985). Um importante exemplo de introdução de germoplasma exótico refere-se ao germoplasma "Tuxpeño", com grande contribuição para o aumento do potencial de produção em variedades e hibridos, em programas de melhoramento no Brasil (Paterniani, 1990).

A utilização de germoplasma de origem tropical em programas de melhoramento em condições temperadas encontra barreiras biológicas como sensibilidade ao comprimento do dia e diferentes características de florescimento quando plantados em altas latitudes como Estados Unidos e Europa (Dowswell et al., 1996). Da mesma forma, a suscetibilidade de germoplasma temperado a viroses e doenças foliares, encontradas em condições tropicais e sub-tropicais de cultivo, tem restringido o uso desses materiais em ambientes tropicais (Kim \& Hallauer, 1989).

Regitano Neto et al. (1997) avaliaram o potencial de 20 populações exóticas, de origem temperada e temperada $x$ tropical, introduzidas no programa de melhoramento de milho, do Departamento de Genética - ESALQNSP. Verificaram que parte deste 
germoplasma podem contrubuir para redução da altura da espiga e número de ramificações no pendão em populações locais. Incorporando germoplasma exótico, com diferentes níveis de adaptação tropical, nas variedades adaptadas BR 105 (Suwan) e BR 106 (Tuxpeño), Regitano Neto (1998) obteve os melhores resultados com a incorporação do germoplasma exótico na variedade adaptada BR 106. O autor também considerou que, de modo geral para os exóticos em estudo, a incorporação não deve ser superior a $50 \%$, sendo que altas doses de material exótico podem comprometer a utilização a curto prazo dessas populações semi-exóticas.

Santos \& Miranda Filho (1992), com a introgressão das raças "Cravo" e "Entrelaçado" na população ESALQ-PB1, ao nível de 50\%, verificaram que as populações semi-exóticas resultantes mostraram-se promissoras para o melhoramento de características da espiga, contribuindo positivamente para um programa de seleção recorrente. Nass \& Miranda Filho (1995) reportaram sobre a depressão por endogamia nessas populações semi-exóticas para diversos caracteres de interesse.

Dentre muitas características as quais verifica-se diversidade genética na espécie Zea mays L., destacam-se as características relacionadas à adaptação a solos ácidos. Programas de melhoramento nessa espécie têm feito uso dos recursos genéticos através da identificação e desenvolvimento de materiais com adaptação a essa condição de solo.

Pandey et al. (1994a), referindo-se ao programa de solos ácidos do CIMMYT, mencionaram que a identificação de germoplasma útil para o melhoramento é realizada com avaliações de coleções de bancos de germoplasma, cultivares e materiais experimentais de programas nacionais e materiais desenvolvidos pelo CIMMYT de ampla adaptação e rendimento. Também comentaram, que a tolerância a solos ácidos não tem sido verificada somente em materiais com origem em regiões de solos ácidos, mas também em materiais cultivados em outras condições de solo.

No programa de solos ácidos do CIMMYT foram desenvolvidas as populações de adaptação tropical e maturação tardia; "South American - 3"(SA-3), SA-4 e SA-5, com grãos amarelos, e SA-6, SA-7 e SA-8, com grãos brancos, as quais têm sido trabalhadas visando atender a necessidade de materiais genéticos de milho para essa condição. Estas populações foram submetidas a seleção recorrente no esquema de progênies de irmãos germanos e progênies $S_{1}$, sendo que a população SA-3, a mais antiga, em fase anterior foi melhorada usando-se seleção recorrente com progênies de meios irmãos. 
Foram definidos os pares heteróticos SA-3 $\times$ SA-4 e SA-6 $\times$ SA-7, os quais estão sendo melhorados através de seleção recorrente reciproca. Derivada deste programa, a variedade Sikuani V-110, ou CIMCALI 91SA3, em 1992/93, obteve em ensaios, em média $45 \%$ maior rendimento que a testemunha em 18 ambientes com solo ácido e $11 \%$ maior rendimento em cinco ambientes com solo não ácido (CIMMYT, 1997).

A Embrapa Milho e Sorgo, em seu programa de solos ácidos, tem identificado, formado e melhorado populações e hibridos de milho visando os solos ácidos brasileiros. Destacam-se as populações CMS 30 (Composto Amplo), CMS 04C (Amarillo Dentado), CMS 14C (Pool 25), CMS 36 (Sintético Cerrado) e CMS 13 (Composto Cerrado), as quais têm sido submetidas a diversas metodologias de seleção recorrente e utilizadas na extração de linhagens (EMBRAPA, 1986; EMBRAPA, 1991). A partir desse programa, a Embrapa Milho e Sorgo já desenvolveu diversas cultivares, como a variedade BR $136 \mathrm{e}$ os hibridos BR 201, BR 205, BR 3123, BRS 2160, BRS 3060 e BRS 3150 (Parentoni').

$O$ Instituto Agronômico (IAC) também tem se dedicado ao melhoramento visando a adaptação a solos ácidos, com ênfase ao alumínio. Utilizando materiais de origem "Cateto", conhecidos por sua tolerância, diversos estudos e materiais foram desenvolvidos (Sawazaki \& Furlani, 1987). Dentre os êxitos do programa, a população IAC Taiúba, com grande variabilidade para tolerância ao Al, tem proporcionado significativos progressos no melhoramento para esse caráter (Lima et al., 1988; Lima et al., 1992; Lima et al., 1995).

\footnotetext{
${ }^{1}$ Parentoni, S.N. (Embrapa Milho e Sorgo, Sete Lagoas, MG) Comunicação Pessoal, agosto, 1999.
} 


\section{MATERIAL E MÉTODOS}

O presente estudo contempla três etapas. Inicialmente, foi feita a avaliação de germoplasma de milho (Zea mays L.) em solo ácido, buscando-se discriminar materiais com adaptação para esta condição. Esta etapa foi constituída por cinco experimentos. Posteriormente, a segunda etapa consistiu em avaliar as variedades de milho de melhor adaptação em solo ácido, quanto ao crescimento de radícula em solução nutritiva, em presença de alumínio. Os materiais com maior adaptação a solo ácido e tolerância ao alumínio, por último, foram cruzados segundo o esquema dialélico, com posterior avaliação em dois níveis de acidez no solo. Empregando-se as médias da tabela dialélica, realizou-se a predição das médias de compostos.

\subsection{Material}

São apresentados a seguir os materiais genéticos avaliados em cada uma das etapas deste estudo. Havendo diferentes tipos de materiais genéticos, para fins de padronização, optou-se em denominá-los por variedades, com exceção para as testemunhas.

\subsubsection{Avaliação de variedades de milho em solo ácido (experimentos 1 a 5)}

As sementes das variedades foram provenientes da coleção de germoplasma de milho do Departamento de Genética da Escola Superior de Agricultura "Luiz de Queiroz" - Universidade de São Paulo, porém oriundas de diversas instituições.

Cinco experimentos constituíram essas avaliações. Nesses experimentos, os híbridos AG 6601 e AG 5011, indicados por serem contrastantes quanto a adaptação a solos ácidos, foram empregados como testemunhas intercalares às parcelas. $O$ hibrido AG 6601, pouco adaptado a solo ácido, é um híbrido triplo modificado, de ciclo normal, com recomendação para plantio em todas as regiões do Brasil. O híbrido AG 5011, com 
boa adaptação a solo ácido, é um híbrido triplo, de ciclo precoce, também com recomendação para plantio em todas as regiões do Brasil.

\section{- Cruzamento dialélico parcial (experimento 1)}

Esse experimento foi constituido por 55 tratamentos, correspondentes a 13 variedades, 6 pertencentes ao Grupo [1] e 7 pertencentes ao Grupo [2], e 42 híbridos obtidos por cruzamento dialélico parcial. As variedades que constituíram o Grupo [1] foram: MOROTI (V1), PORANGATU (V2), TAITINGA (V3), IUBATÃ (V4), TAIÚBA (V5) e WP 12 (V6). As variedades que constituiram o Grupo [2] foram: PHILIPINE DMR 2 (V7), SUWAN 2 (V8), CARIPEÑO DMR (V9), AMARILLO DENTADO DMR (V10), CUPURICO DMR (V11), TUXPEÑO CREMA I (V12) E TUXPEÑO AMARILLO (V13).

As cinco primeiras variedades do Grupo [1] (MOROTI, PORANGATU, TAITINGA, IUBATÃ, TAIÚBA) foram sintetizadas pelo Instituto Agronômico (IAC) (Lima et al., 1988). Juntamente com a variedade WP12, estas variedades são consideradas adaptadas às condições do Estado de São Paulo. As variedades do Grupo [2] são consideradas exóticas (Gorgulho, 1997).

\section{- Cruzamento dialélico (experimento 2)}

O experimento 2 foi constituído por 55 tratamentos, correspondentes a 10 variedades e 45 cruzamentos dialélicos. As 10 variedades foram: BR 105 (V1), CMS 58 (V2), CMS 59 (V3), WP 12 (V4), AMARILLO DENTADO DMR (V5), ESALQ PB2 $x$ ESALQ PB3 (V6), CMS 57 (V7), IAPAR 51 (V8), PMI 8701 (V9) e PMI 9401 (V9).

Conforme Ferreira (1999), essas variedades foram selecionadas a partir dos resultados das avaliações conduzidas pelo Núcleo de Apoio à Pesquisa em Milho (NAPMilho), com ênfase para resistência à Puccinia polysora e produtividade. Em segunda análise, também foram considerados os caracteres resistência a Phaeosphaeria maydis, Physopella zeae, Exserohilum turcicum, complexo enfezamento, acamamento e quebramento.

\section{- Cruzamento "top-cross" intragrupo (experimento 3)}

O experimento 3 foi constituido por 70 tratamentos, correspondentes a 35 variedades e 35 "topcrosses" intragrupo. As 35 variedades foram: CMS 4N (V1), CMS 4C (V2), CMS 14C (V3), CMS 28 (V4), BR 106 (V5), BR 111 (V6), CMS 53 (V7), CMS 54 
(V8), IAPAR 50 (V9), BR 473 (V10), BR 451 (V11), CMS 455CE (V12), PORANGATU (V13), SUWAN 2 (V14), CARIPEÑO DMR (V15), CARIBEAN DMR (V16), CUPURICO DMR (V17), TUXPEÑO CREMA I (V18), BRACIAT (V19), GI 041 (V20), GI 045 (V21), PC 9405 (V22), IAPAR 15 (V23), PMI 9302 (V24), PICHILINGUE (V25), PIRANÃO VD2 (V26), BR 105 (V27), CMS 58ND (V28), CMS 59 (V29), WP 12 (V30), ESALQ PB2 $x$ ESALQ PB3 (V31), CMS 57NF (V32), IAPAR 51 (V33), PMI 8701 (V34) e PMI 9401 (V35).

Conforme Ferreira (1999), essas variedades foram selecionadas a partir dos resultados das avaliações conduzidas pelo Núcleo de Apoio à Pesquisa em Milho (NAPMilho), sendo que nas 26 primeiras variedades, deu-se ênfase quanto a resistência para Puccinia polysora, ficando a produção em segunda análise. As outras 9 variedades são as mesmas que participaram no experimento 2, excetuando-se a variedade Amarillo Dentado DMR.

\section{- Avaliação de variedades "per se" (experimento 4)}

O experimento 4 foi constituído por 50 tratamentos, correspondentes a 50 variedades avaliadas "per se". Destas 50 variedades, 46 foram avaliadas preliminarmente por Mesquita Neto (2000), sendo 23 classificadas como de ciclo super precoce e 23 classificadas como de ciclo precoce.

As 23 variedades super precoces são: BA 166, COMPOSTO JAIBA 3, SE 025, SE 030, COMPOSTO JAIBA 1, PE 011, BA 115, BA 035, RN 003, BA 191, BA 176, AL 001, PE 001, BA 094, SE 036, BA 165, WP 32, PUEBLA GRUPO 27, SAN LUIS POTOSI 127, PR 053, VERA CRUZ 212, JAMAICA 8 e MS 054. As 23 variedades precoces são: MATAHAMBRE X GUAPIRA, CMS 470, CMS 471, BA 042, 1-75-6, CNPH 1, CMS 466, CMS 21, BR 105V, CMS 05, CMS 14, COMPOSTO PLANTA BAIXA, BR 105 MI, CMS 457, SE 033, BRASIL 2294, MEXCLA TROPICAL BLANCO, AL 009, BLANCO CRISTALINO, SAN LUIS POTOSI 118, MS 010, JAMAICA 10 e CMS 50.

As 4 variedades restantes, resultam dos cruzamentos entre as variedades Sikuani, População 73, População 76 e População 79, com origem do Programa Sul Americano do CIMMYT, com a variedade ESALQ PB2 $\times$ ESALQ PB3, com origem do Departamento de Genética da ESALQ/USP. O cruzamento Sikuani x (ESALQ PB2 $\times$ ESALQ PB3) originou a variedade SIKALQ. 


\section{- Avaliação de variedades "per se" (experimento 5)}

O experimento 5 foi constituido por 50 tratamentos, também correspondentes a 50 variedades avaliadas "per se". Destas 50 variedades, 15 corresponderam a gerações $F_{2}$ provenientes do cruzamento entre germoplasma exótico com a variedade adaptada BR 105, e outros 15 corresponderam a gerações $F_{2}$ do cruzamento desse mesmo germoplasma exótico com a variedade adaptada BR 106. O germoplasma exótico empregado nesses cruzamentos foram: BS 11(FR C11), GUADALUPE 5 x MO 17, BS 28 (Tuxpeño (M) C25), IODENT (Isol. Ross Farm), BS 29 (Suwan 1 (M)), ARZM $03056 \times$ MO 17, BUI $103 \times$ B 73, ANTIGUA $3 \times$ MO 17, BS 16 (Int) C0, CUBA $173 \times$ B 73, ANTIGUA (M) C6, CUBA $117 \times$ B 73, CUBA $110 \times$ MO 17, REP. DOMENICANA $269 \times$ B 73 e MEXICAN DENT $\times$ BS 26.

As 20 variedades restantes foram: CMS 13, CMS 39, CMS 454, CMS 463, REPÚBLICA DOMINICANA 300, CMS 458, PUERTO RICO 5, CMS 24, SUWAN DMR original, MG 106, SE 032, BA 044, MG 014, BA 032, BA 187, BA 159, MAYA XVIII, PE 025, CATETO COLOMBIA VIII e PE 028. Essas participaram previamente de um estudo de Pós-Doutorado no Departamento de Genética da ESALQ/USP, visando a identificação de fontes de resistência ao complexo enfezamento (Narro Leon, 1998).

\subsubsection{Crescimento de radícula em solução nutritiva (experimento 6)}

Foram utilizadas 34 variedades no experimento de avaliação de crescimento de radícula, em solução nutritiva contendo alumínio. Essas variedades foram escolhidas a partir dos experimentos realizados na primeira fase deste estudo, ou seja, as variedades com maior adaptação ao solo ácido, sendo estas: TAITINGA, TAIÚBA, CUPURICO DMR, TUXPEÑO AMARILLO, WP 12, PMI 8701, BR 105, CMS 53, CMS 28, CMS 54, CMS 4N, BR 111, SUWAN 2, PC 9405, CMS 57NF, BA 115, BA 191, BA 176, SE 036, WP 32 , PUEBLA GRUPO 27, AL 009, SIKALQ, MS 010, CMS 39, CMS 463, [(CUBA $173 \times$ B 73) $\times$ BR 106], [BS $16 \times$ BR 105], [(CUBA $117 \times B$ 73) $\times$ BR 105], [(CUBA $117 \times B 73) \times B R$ 106], [(CUBA $110 \times$ MO 17) x BR 105], [ANTIGUA $3 \times$ BR 106], [IODENT $\times$ BR 106] e [BS $29 \times$ BR 106].

Os híbridos DINA 766 e MITLA 9560, por suas características de tolerância e sensibilidade aos efeitos do alumínio, respectivamente, foram utilizados como testemunhas. 
3.1.3 Cruzamento dialélico e predição de compostos com adaptação a solo ácido (experimentos 7 e 8)

A partir das avaliações em solo ácido e em solução nutritiva, dez variedades foram escolhidas para realização desta fase do estudo. Essas dez variedades, consideradas com adaptação à condição de solo e tolerância aos efeitos do alumínio, apresentam origem em programas de melhoramento genético do IAC, CIMMYT, Embrapa Milho e Sorgo e ESALQ-Departamento de Genética, sendo descritas a seguir: TAITINGA (V1): Variedade constituida de $87,5 \%$ de germoplasma da população IACTaiúba (grãos amarelos) e 12,5 \% da variedade Tuxpeño-1 (grãos brancos). As plantas são de porte médio, ciclo intermediário e grãos dentados brancos (Lima et al., 1988).

TAIÚBA (V2): Variedade obtida pelo intercruzamento de 13 subpopulações, 12 híbridos e uma variedade comercial. As plantas são de porte médio, ciclo intermediário e bom potencial para produção de grãos, os quais são do tipo dentado e de coloração amareloalaranjado. É reconhecida por sua variabilidade genética para tolerância ao alumínio (Lima et al., 1988).

CUPURICO DMR (V3): Variedade introduzida da Tailândia como fonte de resistência a Peronosclerospora sorghi. Apresenta grãos dentados alaranjados, ciclo precoce e porte médio (Lima et al., 1988).

CMS 53 (V4): Variedade desenvolvida pela Embrapa Milho e Sorgo, sintetizada a partir do intercruzamento de 20 linhagens selecionadas para tolerância ao acamamento. Apresenta grãos duros, ciclo precoce e porte baixo.

SUWAN 2 (V5): Variedade desenvolvida na Tailândia, de grãos duros amareloalaranjados, a partir da recombinação progênies selecionadas da variedade Suwan-1. A variedade Suwan-1 foi obtida pela recombinação de materiais flints tropicais do Caribe e dentados do grupo Tuxpeño. Posteriormente, foram incorporadas duas fontes de resistência a Peronosclerospora sorghi.

SIKALQ (V6): Variedade sintetizada no Departamento de Genética-ESALQ/USP, a partir do intercruzamento da variedade Sikuani com a variedade ESALQ PB2 x ESALQ PB3. A variedade Sikuani, originária da população SA-3, foi desenvolvida pelo CIMMYT objetivando-se a adaptação a solos ácidos. A variedade ESALQ PB2 x ESALQ PB3, com origem no Departamento de Genética-ESALQ/USP, foi obtida pela recombinação de germoplasma de baixa estatura e bom potencial produtivo. 
CMS 39 (V7): Variedade desenvolvida pela Embrapa Milho e Sorgo, sintetizada a partir da recombinação entre 55 cultivares que se destacaram nos ensaios nacionais de milho. $\mathrm{Na}$ sua constituição estão envolvidos hibridos simples, hibridos duplos, hibridos intervarietais e variedades, a maioria com grãos amarelos dentados e semi-dentados (Pacheco, 1987).

BR 105 (V8): Variedade desenvolvida pela Embrapa Milho e Sorgo, a partir da variedade Suwan DMR. Possui grãos duros de coloração alaranjada, plantas baixas e ciclo intermediário. A variedade Suwan foi sintetizada na Tailândia, a partir de materiais flints tropicais do Caribe e dentados do grupo Tuxpeño. A partir de retrocruzamentos foram incorporadas duas fontes de resistência a Peronosclerospora sorghi, sendo lançada como Suwan-1 e introduzida no Brasil como Suwan DMR.

AL 009 (V9): Essa variedade refere-se a um acesso, coletado no Estado de Alagoas. Apresenta grãos semi-dentados de coloração amarela, porte médio a alto e ciclo tardio.

CMS 57NF (V10): Variedade desenvolvida pela Embrapa Milho e Sorgo, tendo na sua composição germoplasma Cateto, Eto e Duros do Caribe. Apresenta grãos duros de coloração amarela e ciclo precoce. Foi submetida a ciclos de seleção em condições de baixa disponibilidade de nitrogênio.

Os hibridos DINA 766 e MITLA 9560, com tolerância e sensibilidade ao aluminio, respectivamente, foram empregados como testemunhas intercalares as parcelas. $O$ hibrido DINA 766 é um hibrido simples modificado, de ciclo super precoce, porte baixo e grãos semi-duros alaranjados, sendo indicado para plantio em todas as regiões do Brasil, inclusive em plantios em "safrinha". O hibrido MITLA 9560 é um hibrido simples, de ciclo precoce, porte intermediário e grãos duros amarelos, sendo indicado para plantio na região Centro-Sul, com restrição para plantios tardios. 


\subsection{Métodos}

A seguir serão descritos os métodos empregados em cada uma das etapas deste estudo.

\subsubsection{Avaliação de variedades de milho em solo ácido (experimentos 1 a 5)}

\subsubsection{Execução experimental}

As avaliações referentes aos cinco experimentos desta etapa foram realizadas no ano agrícola 1997/1998, em área experimental da Fazenda Anhembi da ESALQ/USP, no município de Anhembi, SP. A área experimental corresponde a um solo sob vegetação de "cerrado", de acordo com as caracterís ticas apresentadas por Malavolta \& Kliemann (1985). O solo corresponde à classe aluvial distrófico, textura média-argilosa e relevo plano. As composições química e física médias nas camadas de 0-20 cm e 20-40 cm, são apresentadas no Apêndice $A$.

Os experimentos foram instalados em 13/11/1997, segundo o delineamento em blocos casualizados com quatro repetições. A parcela experimental constou de duas linhas de quatro metros, espaçadas em $0,9 \mathrm{~m}$. Na semeadura foram colocadas 30 sementes por linha, e após 15 dias efetuou-se o desbaste, deixando-se 20 plantas por linha, buscando-se um estande de aproximadamente 55.000 plantas/ha. A cada 14 linhas, foi intercalada uma linha com a testemunha AG 6601, pouco adaptada a solo ácido, e uma linha com a testemunha AG 5011, com adaptação a solo ácido, buscandose ter comparações quanto ao comportamento das variedades em avaliação.

As adubações de plantio e cobertura foram realizadas conforme a análise de solo, buscando-se proporcionar um nivel de nutrientes suficiente para o desenvolvimento das plantas. No plantio a adubação foi de aproximadamente $16 \mathrm{~kg}$ de N/ha, $56 \mathrm{~kg}$ de $\mathrm{P}_{2} \mathrm{O}_{5} /$ ha e $32 \mathrm{~kg}$ de $\mathrm{K}_{2} \mathrm{O} / \mathrm{ha}$. A adubação em cobertura foi de $65 \mathrm{~kg}$ de $\mathrm{N} / \mathrm{ha}$. Os demais tratos culturais e fitossanitários seguiram as recomendações técnicas para a cultura. A semeadura e colheita foram realizadas manualmente.

Foram coletados dados referentes as variáveis:

AP - Altura da planta: altura de plantas competitivas, obtida ao centro da parcela, medindo-se do nível do solo à inserção da folha bandeira, em cm;

AE - Altura da espiga: altura de espigas de plantas competitivas, obtida ao centro da parcela, medindo-se do nível do solo à inserção da espiga superior, em cm; 
$P Q$ - Número de plantas quebradas: número de plantas por parcela com colmos quebrados abaixo da inserção da espiga superior;

$A C$ - Número de plantas acamadas: número de plantas por parcela com colmos acamados;

EF - Estande final: Número de plantas por parcela no momento da colheita;

NE - Número de espigas por parcela: Número de espigas de cada parcela experimental no momento da colheita;

PEo - Peso de espigas observado: Peso das espigas despalhadas por parcela, em kg;

Decorrente das falhas de estande, obteve-se o peso de espigas corrigido (PE) por parcela, para o estande ideal de 40 plantas/parcela, ao nivel de total de parcela, através de análise de covariância, conforme sugerido por Miranda Filho, e apresentado em Vencovsky \& Barriga (1992):

$$
P E=P E o+\hat{b}(N-S), \text { onde: }
$$

$P E:$ peso de espigas corrigido;

PEo: peso de espigas observado;

b: coeficiente de regressão linear do peso de espiga original (PE) em relação às variações de estande (S);

S: estande observado;

N: estande ideal;

$O$ coeficiente de regressão $b$ foi estimado por $b=S P_{x y} / S Q_{x}$, a partir das análises de variância e covariância para estande e produção, segundo o delineamento em blocos casualizados, sendo $x$ o estande e y a produção, $S P_{x y}$ a soma de produtos residual da análise de covariância de estande $x$ e produção y e $S Q_{x}$ a soma de quadrados residual da análise de variância para estande.

\subsubsection{Análises estatístico-genéticas}

\section{Análises de variância}

Para cada um dos cinco experimentos, considerando-se como fixo o efeito de tratamentos, foram realizadas as análises de variância segundo o delineamento em blocos ao acaso, conforme o modelo estatístico abaixo. Foram analisados os caracteres $A P$ e $A E$, em cm; posição relativa da espiga ( $P O)$, sendo a razão $A E / A P$; indice de espigas (IE), sendo a razão NE/EF e peso de espigas corrigido (PE), em t/ha. 


$$
Y_{i j}=m+t_{i}+b_{j}+e_{i j} \text {, onde: }
$$

$Y_{i j:}$ é a observação do tratamento i, no bloco j;

$\mathrm{m}$ : é a média geral do experimento;

$t_{i}$ : é o efeito do tratamento $i$, $(i=1,2, \ldots, i)$;

$b_{j}$ : é o efeito do bloco j, $(j=1,2,3,4)$;

$e_{i j:}$ é o erro experimental associado a observação $Y_{i j}$.

\section{Análises de tabelas dialélicas e de "top-crosses"}

\section{- Cruzamento dialélico parcial (experimento 1):}

A análise dialélica desse experimento, constituído pelas variedades progenitoras e seus híbridos, foi segundo o modelo 4, análise II, de Gardner \& Eberhart (1966), adaptado para dialélicos parciais por Miranda Filho \& Geraldi (1984), conforme apresentado abaixo. A análise foi complementada testando-se os efeitos de capacidade geral de combinação (CGC), conforme o modelo 1, método 4, de Griffing (1956), adaptado para dialélicos parciais por Geraldi \& Miranda Filho (1988).

$$
\mathrm{Y}_{\mathrm{ij}}=\mu+\alpha \mathrm{d}+\frac{1}{2}\left(\mathrm{v}_{\mathrm{i}}+\mathrm{v}_{\mathrm{j}}\right)+\theta\left(\overline{\mathrm{h}}+\mathrm{h}_{\mathrm{i}}+\mathrm{h}_{\mathrm{j}}+\mathrm{s}_{\mathrm{ij}}\right)+\overline{\mathrm{e}}_{\mathrm{ij}} \text {, onde: }
$$

$Y_{i j}$ : é a média do híbrido entre a variedade progenitora i do Grupo [1] e a variedade progenitora j do Grupo [2] ou, para variedades progenitoras $Y_{i j}$ ou $Y_{j j}$, para os Grupos [1] ou [2], respectivamente, é a média observada das variedades "per se"; $\mu$ : é a média dos dois grupos de variedades progenitoras;

$\alpha$ : é um coeficiente de valor 0 (zero) para híbridos, -1 para o grupo de variedades progenitoras de menor média e 1 para o grupo de variedades progenitoras de maior média;

$\mathrm{d}$ : é a medida da diferença entre as médias dos dois grupos de variedades progenitoras;

$v_{i}$ e $v_{j}$ : é o efeito da variedade progenitora i do Grupo [1] e da variedade progenitora j do Grupo [2], respectivamente;

$\theta$ : é um coeficiente condicional, de valor 0 (zero) para variedades progenitoras e 1 para híbridos;

$\bar{h}$ : é a heterose média de todos os híbridos; 
$h_{i}$ e $h_{j}$ : é a heterose da variedade progenitora i do Grupo [1] ou heterose da variedade progenitora j do Grupo [2], que é a contribuição das variedades progenitoras i ou j para o efeito de heterose $h_{\mathrm{ij}}$;

$s_{l l}$ : é a heterose específica do hibrido entre a variedade progenitora $i$ a a variedade progenitora j;

$\bar{e}_{i j}$ : é o erro experimental médio associado a observação $Y_{\mathrm{ij}}$ ou $Y_{\mathrm{ii}}$ ou $Y_{\mathrm{j} j}$.

As análises de variância das tabelas dialélicas e os cálculos das estimativas dos parâmetros componentes das médias, foram conforme as expressões apresentadas por Miranda Filho \& Geraldi (1984) e Geraldi \& Miranda Filho (1988). As expressões para os cálculos das estimativas são apresentadas no Quadro 1.

Quadro 1. Expressões para os cálculos das estimativas dos parâmetros componentes do modelo de análise dialélica parcial.

\begin{tabular}{|c|c|}
\hline Parâmetros & Estimadores \\
\hline Média & $\hat{\mu}=1 / 2\left(\bar{Y}_{(1)}+\bar{Y}_{(2)}\right)$ \\
\hline Desvio entre Grupos & $\hat{\mathrm{d}}=1 / 2\left(\overline{\mathrm{Y}}_{(1)}-\overline{\mathrm{Y}}_{(2)}\right)$ \\
\hline Efeito de variedades do Grupo [1] & $\hat{v}_{\mathrm{i}}=\mathrm{Y}_{\mathrm{ii}}-\overline{\mathrm{Y}}_{(1)}$ \\
\hline Efeito de variedades do Grupo [2] & $\hat{v}_{j}=Y_{j j}-\bar{Y}_{(2)}$ \\
\hline Heterose média & $\hat{\bar{h}}=\bar{Y}_{H}-\hat{\mu}$ \\
\hline Heterose de variedades do Grupo [1] & $\hat{\mathrm{h}}_{\mathrm{i}}=\overline{\mathrm{Y}}_{\mathrm{i}}-\overline{\mathrm{Y}}_{\mathrm{H}}+1 / 2\left(\overline{\mathrm{Y}}_{(1)}-\mathrm{Y}_{\mathrm{ii}}\right)$ \\
\hline Heterose de variedades do Grupo [2] & $\hat{h}_{j}=\bar{Y}_{. j}-\bar{Y}_{H}+1 / 2\left(\bar{Y}_{(2)}-Y_{j j}\right)$ \\
\hline Heterose especifica & $\hat{s_{i j}}=Y_{i j}+\bar{Y}_{H}-\bar{Y}_{i .}-\bar{Y}_{. j}$ \\
\hline CGC de variedades do Grupo [1] & $\hat{g}_{i}=1 / 2 \hat{v}_{i}+\hat{h}_{i}$ \\
\hline CGC de variedades do Grupo [2] & $\hat{g}_{j}=1 / 2 \hat{v}_{j}+\hat{h}_{j}$ \\
\hline
\end{tabular}

As expressões no Quadro 1 seguem notação:

$\mathrm{Y}_{\mathrm{ii}}$ e $\mathrm{Y}_{\mathrm{jj}}$ : são as médias das variedades i e j, respectivamente; 
$\mathrm{Y}_{\mathrm{ij}}$ : é média do hibrido ij;

$\bar{Y}_{(1)}$ e $\bar{Y}_{(2)}$ : são as médias das variedades do Grupo [1] e do Grupo [2], respectivamente;

$\bar{Y}_{i}$ e $\bar{Y}_{j}$ : é a média dos hibridos da variedade i e a média dos híbridos da variedade $j$, respectivamente;

$\bar{Y}_{H}$ : é a média dos hibridos IJ entre grupos.

\section{- Cruzamento dialélico (experimento 2):}

A análise dialélica desse experimento, constituído pelas variedades progenitoras e seus híbridos, foi segundo o modelo 4, análise II, de Gardner \& Eberhart (1966), conforme apresentado abaixo. A análise foi complementada testando-se os efeitos de capacidade geral de combinação (CGC), conforme o modelo 1, método 4, de Griffing (1956).

$$
\mathrm{Y}_{\mathrm{i}^{\prime}}=\mu+\frac{1}{2}\left(\mathrm{v}_{1}+\mathrm{v}_{\mathrm{i}^{\prime}}\right)+\theta\left(\overline{\mathrm{h}}+\mathrm{h}_{\mathrm{i}}+\mathrm{h}_{\mathrm{1}^{\prime}}+\mathrm{s}_{\mathrm{ii}^{\prime}}\right)+\overline{\mathrm{e}}_{\mathrm{ii}^{\prime}} \text {, onde: }
$$

$\mathrm{Y}_{\mathrm{ii}}$ : é o valor médio observado no híbrido entre a variedade i e a variedade i' ou, para variedades progenitoras, $Y_{i i}$ é $\circ$ valor médio observado das variedades progenitoras "per se";

$\mu$ : é a média das variedades progenitoras;

$v_{i}$ e $v_{i}$ : é o efeito da variedade progenitora i ou i';

$\theta$ : é um coeficiente condicional, de valor 0 (zero) para variedades progenitoras (i=i') e 1

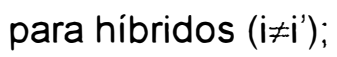

$\overline{\mathrm{h}}$ : é a heterose média de todos os hibridos;

$h_{i}$ e $h_{i}$ : é a heterose da variedade progenitora i ou i', que é a contribuição da variedade progenitora i ou i' para o efeito de heterose $h_{i i i}$;

$\mathrm{s}_{\mathrm{ii}}$ : é a heterose especifica do híbrido entre a variedade progenitora i e a variedade progenitora i';

$\overline{\mathrm{e}}_{\mathrm{ii}}$ : é o erro experimental médio associado a observação $Y_{\mathrm{ii}}$ ou $Y_{\mathrm{ii}}$.

As análises de variância das tabelas dialélicas, foram conforme as expressões apresentadas por Gardner (1967) e Griffing (1956). Os cálculos das estimativas dos parâmetros componentes das médias, foram conforme as expressões apresentadas por 
Gardner \& Eberhart (1966) e Gardner (1967). As expressões para os cálculos das estimativas são apresentadas no Quadro 2.

Quadro 2. Expressões para os cálculos das estimativas dos parâmetros componentes do modelo de análise dialélica.

\begin{tabular}{|c|c|}
\hline Parâmetros & Estimadores \\
\hline Média & $\mu=Y_{v} / n=\bar{Y}_{v}$ \\
\hline Efeito de variedades & $v_{i}=Y_{i j}-Y_{v} / n$ \\
\hline Heterose média & $\overline{\mathrm{h}}=\overline{\mathrm{Y}}_{\mathrm{H}}-\overline{\mathrm{Y}}_{\mathrm{V}}$ \\
\hline Heterose de variedades & $\hat{h}_{\mathrm{i}}=\frac{\mathrm{n}-1}{\mathrm{n}-2}\left(\overline{\mathrm{Y}}_{\mathrm{h} .}-\overline{\mathrm{Y}}_{\mathrm{H}}\right)+1 / 2\left(\mathrm{Y}_{\mathrm{ii}}-\overline{\mathrm{Y}}_{\mathrm{V}}\right)$ \\
\hline Heterose específica & $\hat{s}_{i i}=\left[Y_{i i^{\prime}}-1 / 2\left(Y_{i i}+Y_{i^{\prime} i^{\prime}}\right)\right]-\hat{h}-\hat{h}_{i}-\hat{h}_{i^{\prime}}$ \\
\hline CGC de variedades & $\hat{\mathrm{g}}_{\mathrm{i}}=1 / 2 \hat{\mathrm{v}}_{\mathrm{i}}+\hat{\mathrm{h}}_{\mathrm{i}}$ \\
\hline
\end{tabular}

As expressões no Quadro 2 seguem a notação:

$\mathrm{n}$ : é o número de variedades progenitoras;

$Y_{\mathrm{ii}}$ : é a média de um híbrido, com i $\neq \mathrm{i}^{\prime}$;

$Y_{\mathrm{ii}}$ : é a média da variedade progenitora i,com i=i';

$Y_{V}$ : é a soma das médias das variedades progenitoras ou soma dos termos da diagonal da tabela dialélica;

$\mathrm{Y}_{\mathrm{H}}$ : é a soma das médias de todos os híbridos ou soma dos valores acima da diagonal da tabela dialélica;

$\bar{Y}_{\mathrm{h}}$ : é a média dos híbridos em que participa a variedade progenitora i.

\section{- Cruzamento "top-cross" intragrupo (experimento 3):}

A análise desse experimento, constituído pelas variedades progenitoras e seus "topcrosses", foi segundo o modelo 3 (reduzido), análise II, de Gardner \& Eberhart (1966), sugerido para análise de "top-cross" intragrupo por Chaves \& Miranda Filho (1997), conforme apresentado abaixo. A análise foi complementada testando-se os efeitos de capacidade geral de combinação (CGC), de acordo com o modelo 1, método 4, de Griffing (1956). 


$$
Y_{i^{\prime}}=\mu+\frac{1}{2}\left(v_{i}+v_{i^{\prime}}\right)+\theta\left(\bar{h}+h_{i}+h_{i^{\prime}}\right)+\bar{e}_{i^{\prime}}
$$

Os efeitos componentes deste modelo são os mesmos apresentados na análise de cruzamento dialélico (experimento 2).

As análises de variância em "top-crosses" intragrupo, a partir das médias das variedades e "topcrosses", foram conforme as expressões apresentadas por Chaves \& Miranda Filho (1997). Também os cálculos das estimativas dos parâmetros componentes das médias, foram conforme as expressões apresentadas por Chaves \& Miranda Filho (1997), como seguem no Quadro 3.

Quadro 3. Expressões para os cálculos das estimativas dos parâmetros componentes do modelo de análise de "top-cross" intragrupo.

\begin{tabular}{ll}
\hline Parâmetros & Estimadores \\
\hline Média & $\hat{u}=\bar{V}$ \\
Efeito de variedades & $v_{i}=V_{i}-\bar{V}$ \\
Heterose média & $\bar{h}=\frac{n}{n-1}(\bar{T}-\bar{V})$ \\
Heterose de variedades & $\hat{\mathrm{h}}_{i}=\frac{n}{n-2}\left[\left(T_{i}-\bar{T}\right)-l / 2\left(V_{i}-\bar{V}\right)\right]$ \\
CGC de variedades & $\hat{g}_{i}=1 / 2 \hat{v}_{i}+\hat{h}_{i}$
\end{tabular}

As expressões no Quadro 3 seguem a notação:

$\mathrm{n}$ : é o número de variedades progenitoras;

$V_{i}$ e $T_{i}$ : É o valor médio da variedade progenitora i e do "topcross" envolvendo a variedade progenitora $\mathrm{i}$, respectivamente;

$\bar{V}$ e $\bar{T}$ : são as médias das variedades progenitoras e dos "topcrosses", respectivamente.

\subsubsection{Crescimento de radícula em solução nutritiva (experimento 6)}

\subsubsection{Execução experimental}

A avaliação de crescimento de radícula de plântulas de milho em solução nutritiva, foi realizada no Setor de Nutrição Mineral de Plantas do Instituto Agronômico (IAC), na Estação Experimental de Campinas. Esse experimento foi instalado na segunda quinzena do mês de julho de 1998, empregando-se o delineamento 
experimental em blocos ao acaso com três repetições. A parcela experimental, referente a cada variedade, foi composta de 22 plântulas.

$\mathrm{Na}$ solução nutritiva foram usados os seguintes nutrientes, em mg/l: Ca (140), $\mathrm{K}$ (90), $\mathrm{Mg}(20), \mathrm{N}-\mathrm{NO}_{3}(148), \mathrm{N}_{-} \mathrm{NH}_{4}(18), \mathrm{S}_{-} \mathrm{SO}_{4}(20), \mathrm{P}-\mathrm{PO}_{4}(1,0), \mathrm{Fe}(1,5), \mathrm{B}(0,10), \mathrm{Cu}$ $(0,02), M n(0,20)$, Mo $(0,03), \mathrm{Zn}(0,06)$ e $\mathrm{Al}(4,5)$. O pH inicial foi próximo de 4,0 (Furlani, 1995).

Foram adotados os seguintes procedimentos no preparo do material experimental e na condução da avaliação: As sementes de milho das variedades e das testemunhas foram colocadas para germinar em rolos de papel-toalha, umedecidos com água. Três dias após o inicio da germinação, quando as radiculas estavam com comprimento entre 5 a $10 \mathrm{~cm}$, as plântulas foram transferidas para solução nutritiva. Nesta ocasião, tomando-se o cuidado de eliminar as raizes seminais laterais, mediu-se o comprimento inicial de radicula ( $C$ inicial). Após 8 dias do transplante para a solução nutritiva, as plântulas foram colhidas, medindo-se o comprimento final de radicula ( $C$ final).

A partir da diferença entre comprimento final ( $C$ final) e comprimento inicial $(C$ inicial), obteve-se o comprimento liquido de radicula (CL) para as variedades e testemunhas. Considerando-se o comprimento liquido de radicula da testemunha tolerante e o comprimento liquido de radicula da testemunha sensivel, obteve-se, para cada variedade, o comprimento líquido de radicula em relação a testemunha tolerante (CLRTT) e o comprimento liquido de radicula em relação a testemunha sensivel (CLRTS).

\subsubsection{Análises estatísticas}

Nas análises de variância para as variáveis CL, CLRTT e CLRTS, considerou-se o modelo matemático para o delineamento em blocos ao acaso, como a seguir:

$$
\mathrm{Y}_{\mathrm{ij}}=\mathrm{m}+\mathrm{t}_{\mathrm{i}}+\mathrm{b}_{\mathrm{j}}+\mathrm{e}_{\mathrm{ij}} \text {, onde: }
$$

$Y_{i j}$ é a observação da variedade $i$, no bloco j;

m: é a média geral do experimento;

$t_{i}$ : é o efeito do tratamento $i,(i=1,2, \ldots, l)$;

$b_{j}$ : é o efeito do bloco j, $(j=1,2,3)$;

$e_{i j}$ : é o erro experimental associado a observação $Y_{i j}$. 


\subsubsection{Cruzamento dialélico e predição de compostos com adaptação a solo ácido} (experimentos 7 e 8 )

\subsubsection{Execução experimental}

A partir das dez variedades selecionadas nas avaliações anteriores, nesta etapa, foram obtidos os 45 cruzamentos em esquema dialélico, além da multiplicação das variedades progenitoras. O campo de cruzamentos e multiplicação foi instalado no mês de agosto de 1998, na área experimental do Departamento de Genética da ESALQ USP. Foram usadas linhas pareadas, com $10 \mathrm{~m}$ de comprimento e por ocasião do florescimento feminino, os estilo-estigmas foram protegidos; quando houve suficiente disponibilidade de pólen, foram realizados os cruzamentos. As polinizações foram em cerca de 60 a 80 espigas por par de fileiras. Após a colheita das espigas de ambas as fileiras, desconsiderando-se os cruzamentos reciprocos, fez-se a amostragem de 50 sementes por espiga. As sementes amostradas em cada cruzamento e em cada variedade progenitora "per se", foram misturadas, vindo a contituir o material experimental para avaliação.

Os 45 híbridos e as dez variedades foram avaliadas no ano agricola 1998/1999, em "safrinha", com semeadura em 03/03/1999, em dois experimentos (experimentos 7 e 8, respectivamente), na área experimental da Fazenda Anhembi da ESALQ/USP, no municipio de Anhembi, SP. A área experimental foi a mesma empregada nas avaliações correspondentes ao ítem 3.2.1 (Avaliação de variedades de milho em solo ácido), sendo um solo sob vegetação de "cerrado", conforme Malavolta \& Kliemann (1985), correspondente à classe aluvial distrófico, textura média-argilosa e relevo plano.

O experimento 7 constituiu-se da avaliação em solo original, ou seja, sem a adição de calcáreo. Já o experimento 8 correspondeu a avaliação em solo onde realizouse uma calagem parcial. Neste caso, adicionou-se cerca de 3,5 t/ha de calcáreo dolomítico, com PRNT (poder real de neutralização total) em tomo de $80 \%$. Este procedimento teve como objetivo elevar o pH, os teores de cálcio e magnésio, bem como reduzir a saturação com alumínio no solo. A composição química média, nas camadas de 0-20 cm e 20-40 cm, nos solos referentes aos experimentos 7 e 8 , respectivamente, é apresentada no Apêndice $B$.

Os experimentos foram instalados segundo 0 delineamento em blocos casualizados com seis repetições. A parcela experimental constou de duas linhas de quatro metros, espaçadas em $1 \mathrm{~m}$. Na semeadura foram colocadas 30 sementes por 
linha, e após 15 dias efetuou-se o desbaste, deixando-se 20 plantas por linha, buscando-se um estande de aproximadamente 50.000 plantas/ha. A cada 14 linhas, semeou-se uma linha com a testemunha DINA 766, com tolerância ao alumínio, e uma linha com a testemunha Mitla 9560, sensivel ao aluminio, buscando-se ter comparações quanto ao comportamento das variedades e cruzamentos em avaliação.

As adubações de plantio e cobertura foram realizadas conforme a análise de solo, buscando-se proporcionar um nivel de nutrientes suficiente para o desenvolvimento das plantas. No plantio a adubação foi de aproximadamente $16 \mathrm{~kg}$ de N/ha, $56 \mathrm{~kg}$ de $\mathrm{P}_{2} \mathrm{O}_{5} /$ ha e $32 \mathrm{~kg}$ de $\mathrm{K}_{2} \mathrm{O} / \mathrm{ha}$. A adubação em cobertura foi em torno de $65 \mathrm{~kg}$ de $\mathrm{N} / \mathrm{ha}$. Os demais tratos culturais e fitossanitários seguiram as recomendações técnicas para a cultura. A semeadura e colheita foram realizadas manualmente.

Além dos dados das variáveis descritas no item 3.2.1 (experimentos 1 a 5), também foram coletados dados referentes as variáveis:

DF - Dias para florescimento masculino: Número de dias decorrentes da emergência até a emissão da inflorescência masculina (pendão) em $50 \%$ das plantas da parcela;

CE - Comprimento de espigas: Comprimento de dez espigas despalhadas por parcela, em cm;

DE - Diâmetro de espigas: Diâmetro de dez espigas despalhadas por parcela, em $\mathrm{cm}$;

PGo - Peso de grãos observado: Após debulhadas as espigas, obteve-se o peso de grãos por parcela, em kg.

Decorrente das falhas de estande, obteve-se o peso de grãos corrigido (PG) por parcela, para o estande ideal de 40 plantas/parcela, em nivel de total de parcela, através de análise de covariância, conforme sugerido por Miranda Filho, e apresentado em Vencovsky \& Barriga (1992). Este procedimento foi da mesma forma descrita no item 3.2.1.1.

\subsubsection{Análises estatístico-genéticas}

\section{Análises de variância}

Em cada um dos experimentos, considerando-se como fixo o efeito de tratamentos, foram realizadas as análises de variância para os caracteres $A P, A E, C E$ e 
$D E$, em cm; e PG, em t/ha, segundo o delineamento em blocos ao acaso, conforme o modelo já apresentado no ítem 3.2.1.2.

As análises de variância conjuntas de experimentos, considerando-se como fixo o efeito de tratamentos e o efeito de experimentos, foram conforme o modelo matemático:

$$
\mathrm{Y}_{\mathrm{ij}_{\mathrm{k}}}=\mathrm{m}+\mathrm{t}_{\mathrm{i}}+\mathrm{l}_{\mathrm{k}}+\mathrm{b}_{\mathrm{j}_{\mathrm{K}}}+\overline{\mathrm{e}}_{\mathrm{ijk}} \text {, onde: }
$$

$Y_{\mathrm{ijk}}$ é a observação do tratamento i, no blocoj, dentro do experimento k;

$\mathrm{m}$ : é a média geral dos experimentos;

$t_{i}$ : é o efeito do tratamento i $(i=1,2, \ldots, l)$;

$I_{k}$ : é o efeito do experimento $k(k=1,2)$;

$b_{j}$ : é o efeito do bloco j, dentro do experimento $k(j=1,2, \ldots, 6)$;

$\overline{\mathrm{e}}_{\mathrm{ijk}}$ : è o erro experimental médio, associado a observação $Y_{\mathrm{ijk} \text {. }}$

\section{Análises de tabelas dialélicas}

As análises dialélicas para cada um dos experimentos, constituidos pelas variedades progenitoras e seus híbridos, foram segundo 0 modelo 4, análise II, de Gardner \& Eberhart (1966), e o modelo 1, método 4, de Griffing (1956), da mesma forma que o apresentado no item 3.2.1.2, referente ao experimento 2.

As análises dialélicas conjuntas, referentes aos experimentos 7 e 8 , foram conforme o modelo 4, análise II, de Gardner \& Eberhart (1966), adaptado para mais de um ambiente por Morais et al. (1991), conforme apresentado abaixo. Os efeitos de CGC foram testados empregando-se o modelo 1, método 4, de Griffing (1956), adaptado para mais de um ambiente por Ferreira et al. (1993).

$$
Y_{i i j}=\mu+\frac{1}{2}\left(v_{i}+v_{i j}\right)+e_{j}+\frac{1}{2}\left(v_{i j}+v e_{i j j}\right)+\theta\left(h_{i i}+h e_{i i j}\right)+\bar{e}_{i i j} \text {, onde: }
$$

$Y_{i i j}$ : é o valor médio observado no hibrido entre a variedade i e a variedade i' no experimento j ou, para variedades progenitoras, $\mathrm{Y}_{\mathrm{ii}}$ é o valor médio observado das variedades progenitoras "per se" no experimento j;

$\mu$ : é a média das variedades progenitoras;

$v_{i}$ e $v_{i}$ : é o efeito da variedade progenitora i ou i';

$e_{j}$ : é o efeito do experimento j; 
$\mathrm{ve}_{\mathrm{ij}}$ e ve $\mathrm{e}_{\mathrm{ij}}$ : é o efeito da interação entre o efeito da variedade progenitora i e o efeito do ambiente $j$, e o efeito da interação entre o efeito da variedade progenitora $i$ e o efeito do ambiente j, respectivamente;

6: é um coeficiente condicional, de valor o (zero) para variedades progenitoras (i=i') e 1 para hibridos (i $\left.\neq i^{\prime}\right)$;

$h_{i i}$ : é o efeito da heterose no hibrido entre a variedade progenitora i e a variedade progenitora i';

$h_{\mathrm{iij}}$ : é o efeito da interação entre o efeito de heterose $h_{\mathrm{ii}}$ e o efeito de experimento j;

$\overline{\mathrm{e}}_{\mathrm{iij}}$ : é o erro experimental médio associado a observação $Y_{i i j}$ ou $Y_{i i j}$;

O efeito da heterose tem a seguinte composição:

$$
\mathrm{h}_{\mathrm{ii}}=\overline{\mathrm{h}}+\mathrm{h}_{\mathrm{i}}+\mathrm{h}_{\mathrm{i}}+\mathrm{s}_{\mathrm{ii}} \text {, onde: }
$$

$\overrightarrow{\mathrm{h}}$ : é a heterose média de todos os hibridos;

$h_{i}$ e $h_{i^{\prime}}$ : é a heterose da variedade progenitora i ou i', que é a contribuição da variedade progenitora i ou i' para o efeito da heterose $h_{i i}$;

$\mathrm{S}_{\mathrm{ii}}$ : é a heterose especifica do hibrido entre a variedade progenitora i e a variedade progenitora i';

O efeito da interação heterose $x$ experimento tem a seguinte composição:

$$
h e_{i i j}=\overline{h e}_{j}+h e_{i j}+h e_{i j}+s e_{i i j} \text {, onde: }
$$

$\bar{h}_{j}$ : é o efeito da interação entre o efeito da heterose média e o efeito do experimento j;

he $_{\mathrm{ij}}$ e he $\mathrm{ij}_{\mathrm{j}}$ : é o efeito da interação entre o efeito da heterose da variedade progenitora $\mathrm{i}$ ou i’ e o efeito do experimento j;

$\mathrm{se}_{\mathrm{iij}}$ : é o efeito da interação entre o efeito da heterose especifica e o efeito do experimento j;

As análises dialélicas conjuntas de experimentos e os cálculos das estimativas dos parâmetros componentes das médias, foram conforme as expressões apresentadas por Morais et al. (1991) e Ferreira et al. (1993). 


\subsubsection{Predição de médias de compostos}

A partir de 10 variedades é possivel a obtenção de um grande número compostos, ou seja, 1013 compostos. Sendo dispendiosa a predição de médias para esse número de compostos, envolvendo vários caracteres, adotou-se iniciaimente um critério auxiliar para a seleção das variedades com maiores possibilidades de contribuição para a média de compostos. Este critério, sugerido por Miranda Filho \& Chaves (1991), corresponde as estimativas do índice $l_{i}$, como apresentado a seguir:

$$
I_{i}=w_{1} v_{i}+w_{2} h_{i} \text {, onde: }
$$

$I_{i}$ : é a contribuição da variedade progenitora i para média de um composto de tamanho k:

$w_{1} \& w_{2}$ : são coeficientes, sendo $w_{1}=1 / k$ e $w_{2}=2(k-1) / k^{2}$, respectivamente. sendo $k o$ tamanho do composto;

$\mathrm{v}_{\mathrm{i}}$ : é a estimativa do efeito de variedade, referente a variedade progenitora $\mathrm{i}$;

$h_{i}$ : è a estimativa do efeito de heterose de variedade, referente a variedade progenitora i.

Entre as 10 variedades, foram selecionadas as 5 variedades com as maiores estimativas para $o$ indice $l_{i}$, realizando-se a predição de compostos de tamanhos $k=2$ a $k=5$.

Para a predição das médias dos compostos, foram utilizados os valores médios da análise conjunta dos experimentos 7 e 8 . Foram estimadas as médias para os caracteres $A P, A E, \% A C, \% P Q, D F, C E, D E, I E$ e $P G$, conforme a metodologia apresentada por Eberhart et al. (1967), empregando-se a expressão a seguir:

$$
Y_{k}=\bar{H}-\left(\frac{\bar{H}-\bar{V}}{n}\right) \text {, onde: }
$$

$Y_{k}$ : é a média do composto formado por $k$ variedades progenitoras;

$\overline{\mathrm{H}}$ : é a média de todos os híbridos que envolvem as variedades progenitoras;

$\overline{\mathrm{V}}$ : é a média das variedades progenitoras;

$\mathrm{n}$ : é o número de variedades progenitoras; 


\section{RESULTADOS E DISCUSSÃO}

\subsection{Avaliação de variedades de milho em solo ácido}

Esta etapa inicial do estudo, constituida pela avaliação de cinco experimentos em solo ácido, objetivou identificar as variedades de melhor desempenho produtivo na referida condição, em termos de peso de espigas (PE). Neste sentido, a área experimental foi escolhida por suas caracteristicas químicas. destacando-se o baixo $\mathrm{pH}$, saturação com aluminio e baixos niveis dos elementos fósforo, potássio, cálcio e magnésio (Apêndice 1). Esse conjunto de fatores e suas relações, estabelecem uma condição de solo restritiva ao desenvolvimento e a produção das plantas de milho, o que poderá ser verificado nos resultados dos experimentos. A avaliação de outros caracteres agronômicos, como altura da planta (AP), altura da espiga (AE), posição relativa da espiga (PO) e indice de espigas (IE), foi com o intuito de verificar possiveis limitações do germoplasma ao cultivo.

No periodo de condução dos experimentos, correspondente ao de safra da cultura, as condições climáticas ocorreram de modo propício ao desenvolvimento das plantas. Fatores como temperatura e precipitação foram em niveis normais. Entre os fatores fitossanitários, destacaram-se a ocorrência de Spodoptera frugiperda (lagarta do cartucho), e a incidência de doenças como Phaeosphaeria maydis e complexo enfezamento. A população de lagartas foi mantida em niveis adequados através de controle quimico. Quanto as doenças, de incidência comum no local de avaliação, foram consideradas não prejudiciais aos objetivos deste estudo.

Os valores de coeficiente de variação experimental (CV), verificados nos cinco experimentos (Tabelas 1, 5, 9, 12 e 14), foram de magnitudes consideradas satisfatórias na experimentação a campo com milho, em condição de estresse de solo, sendo próximas as verificadas nos estudos de Eleutério et al. (1988), Lima et al. (1992) e Santos et al. (1998). O PE, caracteristica de maior complexidade, apresentou valores de CV entre 16,2 \%, no experimento 2 (Tabela 5), a $20,7 \%$, no experimento 4 (Tabela 12). Em se 
tratando de condição de estresse, e tendendo-se a menores médias, esses valores podem ser considerados razoáveis. Scapim et al. (1995), em estudo sobre classificação de coeficientes de variação na experimentação a campo com milho, considera valores nessas magnitudes como médios, em uma escala que contempla baixo, médio, alto e muito alto.

Um aspecto comum aos cinco experimentos é quanto ao comportamento das testemunhas intercalares. As testemunhas AG $6601\left(T_{1}\right)$ e $A G 5011\left(T_{2}\right)$, escolhidas "a priori" por adaptações contrastantes às condições de solo ácido, mostraram-se distintas para os caracteres altura da planta $(A P)$ e altura da espiga $(A E)$. Em termos de $P E$, os desempenhos foram aproximados. Nos experimentos 3, 4 e 5 (Tabelas 9, 12 e 14, respectivamente), a testemunha AG 5011 obteve maiores médias, porém com uma diferença máxima, no experimento 4 , de 0,45 t/ha, em relação a $A G 6601$ (Tabela 12). $A$ testemunha AG 6601 foi superior no experimento 1 (Tabela 1), com uma diferença de 0,19 tha em relação a $A G$ 5011. Uma possibilidade para a restrita diferença na produtividade das testemunhas, nos cinco experimentos, é quanto a ocorrência de um nível de estresse elevado, restritivo inclusive à testemunha AG 5011, com maior expectativa de adaptação.

A seguir são apresentados os resultados para cada um dos cinco experimentos, os quais orientaram para a escolha das variedades de melhor adaptação.

\subsubsection{Cruzamento dialélico parcial (experimento 1)}

Esse experimento constituiu-se de dois grupos de variedades progenitoras e seus híbridos. A seguir são apresentadas as médias, as análises das tabelas dialélicas, as estimativas de parâmetros e as variedades selecionadas para serem avaliadas em etapas seguintes deste estudo.

\section{Médias das variedades e híbridos}

Para os caracteres altura da planta (AP), altura da espiga (AE), posição relativa da espiga (PO), indice de espigas (IE) e peso de espigas (PE), foram observados coeficientes de variação experimental (CV) de 7,2 \%, 11,7 \%, 7,5 \% 12,9 \% e 19,2 \%, respectivamente (Tabela 1 ).

Entre as 13 variedades avaliadas "per se", seis variedades do Grupo [1] e as sete variedades do Grupo [2], e seus respectivos híbridos, os intervalos de variação das médias de $A P$ e $A E$, respectivamente, foram entre $155 \mathrm{~cm}$ a $218 \mathrm{~cm}$ e $79 \mathrm{~cm}$ a $136 \mathrm{~cm}$ 
(Tabela 1). A variedade WP 12, Grupo [1], apresentou os maiores valores de AP, AE e PO. Já a variedade TUXPEÑO AMARILLO, Grupo [2], obteve os menores valores para esses caracteres. A testemunha AG 6601 revelou médias de AP e AE de $159 \mathrm{~cm}$ e $84 \mathrm{~cm}$, respectivamente, próximas as menores médias entre os tratamentos. As médias da testemunha AG 5011 foram de $181 \mathrm{~cm}$ e $108 \mathrm{~cm}$, respectivamente, próximas a média do experimento.

O IE variou entre 0,57 a 0,90 (Tabela 1), indicando que em todos os tratamentos ocorreram plantas sem espiga. Essa falta de espigas foi mais acentuada no hibrido IUBATÃ X TUXPEÑO CREMA I, com 0,57; enquanto que os maiores indices foram verificados na variedade IUBATÃ e no hibrido TAITINGA $\times$ PHILIPINEDMR, com 0,90. A ocorrência de plantas sem espigas granadas pode ser atribuída aos efeitos da acidez e a baixa disponibilidade de nutrientes, ocasionando uma série de disturbios fisiológicos, fato também relatado por Naspolini Filho et al. (1981) e Pandey et al. (1994).

O PE apresentou variação entre 2,31 t/ha a 4,34 tha (Tabela 1). O hibrido IUBATÃ $x$ TUXPEÑO CREMA I, de menor IE, também foi um dos menos produtivos com 2,32 t/ha. Entre as variedades avaliadas "per se", SUWAN 2, TAITINGA, CUPURICO DMR, TAIÚBA, IUBATÃ, TUXPEÑO AMARILLO e AMARILLO DENTADO DMR, nesta ordem, foram as mais produtivas, superando 3 t/ha. Destacaram-se os hibridos TAITINGA $x$ TUXPEÑO AMARILLO, MOROTI $\times$ TUXPEÑO AMARILLO, TAITINGA $\times$ CARIPEÑO DMR, TAIÚBA $\times$ SUWAN 2 e TAIÚBA $\times$ CUPURICO DMR, com produtividades superiores a 4 t/ha. As produtividades das testemunhas não foram superadas, entretanto o hibrido TAITINGA x TUXPEÑO AMARILLO obteve $95,3 \%$ e 99,5 \% em relação a $T_{1}$ e $T_{2}$, respectivamente.

O Grupo [1], composto pelas seis primeiras variedades, é considerado de maior adaptação às condições do Estado de São Paulo, sendo que as cinco primeiras variedades foram sintetizadas pelo Instituto Agronômico (IAC). Por outro lado, o Grupo [2] constituiu-se de variedades exóticas (Gorgulho, 1997). Nesse sentido, em termos de comportamento "per se" das variedades, havia a expectativa de melhores produtividades pelas variedades do Grupo [1]. Entretanto, entre as variedades com produtividades superiores a 3 t/ha, três são pertencentes a o grupo I e quatro são pertencentes aos Grupo [2]. Uma possivel explicação para esse comportamento, é a ocorrência de interação variedades $x$ ambientes, a qual pode ter sido incrementada pela condição ambiental de estresse. $A$ interação pode resultar em desempenhos diversos e não concordantes com os verificados em outros ambientes. 
Comparativamente aos resultados de Gorgulho (1997), com este mesmo conjunto de tratamentos, em avaliação em Anhembi-SP, a média de PE foi inferior em aproximadamente $3,16 \mathrm{t} / \mathrm{ha}$, ou seja, obteve-se $3,36 \mathrm{t} / \mathrm{ha}$, enquanto $\mathrm{o}$ referido autor verificou 6,52 t/ha. Em termos de $A P$ e $A E$, as médias verificadas por Gorgulho (1997) foram superiores em aproximadamente $20 \mathrm{~cm}$. A variedade PHILIPINEDMR foi um dos tratamentos menos produtivos em ambas avaliações. Também em ambas as avaliações a variedade WP 12 destacou-se pela maior estatura. $O$ tratamento mais produtivo verificado por Gorgulho (1997) foi o hibrido PORANGATU x TUXPEÑO CREMA I. As variedades TAITINGA, TAIÚBA e IUBATÃ e os híbridos PORANGATU x PHILIPINEDMR 2 , PORANGATU $\times$ TUXPEÑO CREMA I, TAITINGA $\times$ CUPURICO DMR, TAITINGA $\times$ TUXPEÑO AMARILLO, IUBATÃ $\times$ CUPURICO DMR E TAIÚBA $\times$ CARIPEÑO DMR estiveram entre os tratamentos mais produtivos em ambas as avaliações.

As diferenças nas médias em relação as verificadas por Gorgulho (1997), referindo-se ao mesmo conjunto de tratamentos e local de avaliação, podem ser relacionadas aos efeitos de ano de avaliação, mas principalmente, aos efeitos das condições quimicas de solo nas áreas experimentais. A avaliação realizada por Gorgulho (1997) foi conduzida em área experimental com condições de ácidez e disponibilidade de nutrientes em niveis satisfatórios para o desenvolvimento e produtividade das plantas. Portanto, as diferenças nas médias ressaltam as diferentes condições de avaliação, alertando para as possibilidades de identificação de variedades e híbridos promissores.

\section{Análises de variância}

Os efeitos de variedades do Grupo [1] e variedades do Grupo [2], respectivamente, foram significativos para as caracteres AP, AE e PE (Tabela 2). O contraste entre os grupos de variedades foi significativo para AP e AE. Já os efeitos de heterose e seus componentes foram não significativos, com exceção para o efeito de heterose média para o PE. Os efeitos de capacidade geral de combinação (CGC) apresentaram variação significativa para AP, AE e PE, tanto para as variedades do Grupo [1], quanto para as variedades do Grupo [2] (Tabela 2).

Tendo-se grupos de variedades, "a priori", distintos em niveis de melhoramento e adaptação, havia expectativa em verificar significância para o contraste entre grupos, não só para $A P$ e $A E$, mas também para $P E$. Nesse aspecto, a ocorrência de interação variedades $x$ ambientes pode alterar a expectativa de comportamento médio dos grupos, os quais passam a ter desempenhos médios aproximados, resultando em efeito não significativo. Para o caráter PE, Gorgulho (1997), em avaliação em Anhembi-SP, não 
verificou significância para os efeitos de variedades do Grupo [2] e verificou significância para o contraste entre grupos de variedades. Esses resultados reforçam a possibilidade de que o ambiente interagiu com as variedades. estabelecendo novas relações entre os comportamentos das mesmas.

A significância da heterose média é indicativa da distinção entre variedades e hibridos. Para o PE, embora a diferença entre as médias das variedades e a média dos hibridos tenha sido de apenas 0,29 t/ha, ou seja, 3,13 t/ha vs. 3,42 t/ha, respectivamente, constatou-se significância para este efeito. A heterose média é um efeito componente da heterose total, entretanto, a heterose total foi não significativa.

Efeitos de heterose não significativos podem ser indicativos de pouca divergência genética entre as variedades e/ou ausência de efeitos de dominância e/ou efeitos de dominância não direcionais. Gorgulho (1997) na avaliação em Anhembi, SP, também não constatou efeitos significativos para heterose de variedades e heterose especifica.

Como a CGC é função de efeitos de variedades e de efeitos de heterose de variedades, a significância dos efeitos de CGC deve ser atribuida primeiramente aos efeitos de variedades, haja vista a não significância dos efeitos de heterose de variedades. Embora os resultados não permitam inferir sobre a ausência de efeitos de genéticos de dominância, presume-se uma maior importância para os efeitos genéticos aditivos, principalmente na manifestação dos caracteres AP e AE. A relação entre os quadrados médios de CGC e os quadrados médios de heterose específica são indicativas desta importância.

\section{Estimativas de parâmetros}

A estimativa da média dos grupos de variedades $(\mu)$ para $A P, A E$ e $P E$, respectivamente, foram de $118,0 \mathrm{~cm}, 102,6 \mathrm{~cm}$ e $3,139 \mathrm{t} / \mathrm{ha}$. As estimativas para os desvios entre as médias dos grupos de variedades (d), para $A P, A E$ e $P E$, respectivamente, foram de $9,6 \mathrm{~cm} ; 6,8 \mathrm{~cm}$ e 0,067 t/ha (Tabela 3).

As estimativas de efeitos de variedades do Grupo [1] $\left(v_{i}\right)$, para AP, AE e PE, respectivamente, foram entre $-18,6 \mathrm{~cm}$ a $20,3 \mathrm{~cm},-16,5 \mathrm{~cm}$ a $26,5 \mathrm{~cm}$ e $-0,346 \mathrm{t} / \mathrm{ha}$ a 0,443 t/ha. Para o PE, a variedade TAITINGA foi a de maior estimativa $(0,443 \mathrm{t} / \mathrm{ha})$, seguida pelas variedades TAIÚBA $(0,193 \mathrm{t} / \mathrm{ha})$ e IUBATÃ $(0,143 \mathrm{t} / \mathrm{ha})$. Entre estas, os efeitos de variedades para $A P$ e $A E$ foram negativos para as variedades IUBATÃ e TAIÚBA e positivos para a variedade TAITINGA, porém de baixa magnitude (Tabela 3 ).

As estimativas de efeitos de variedades do Grupo [2] $\left(v_{j}\right)$, para AP, AE e PEC, respectivamente, foram entre $-23,42 \mathrm{~cm}$ a $9,57 \mathrm{~cm},-16,71 \mathrm{~cm}$ a $9,28 \mathrm{~cm}$ e $-0,761 \mathrm{t} / \mathrm{ha}$ a 
0,788 t/ha. Para o PE, destacaram-se as variedades SUWAN 2 (0,788 t/ha), CUPURICO DMR $(0,448 \mathrm{t} / \mathrm{ha})$ e TUXPEÑO AMARILLO $(0,218 \mathrm{t} / \mathrm{ha})$. As variedades TUXPEÑO AMARILLO e CUPURICO DMR apresentaram estimativas negativas para AP e AE. Para estes caracteres, a variedade SUWAN 2 apresentou estimativas positivas, entretanto pouco elevadas (Tabela 3 ).

As estimativas de heterose média $(\bar{h})$ para $A P, A E$ e $P E$, respectivamente, foram de $-1,7 \mathrm{~cm}, 0,2 \mathrm{~cm}$ e 0,289 t/ha. Os efeitos de heterose de variedades do Grupo [1] $\left(h_{i}\right) \mathrm{e}$ heterose de variedades do Grupo [2] $\left(h_{j}\right)$, respectivamente, embora estatisticamente não significativos, apresentaram estimativas entre $-0,477$ t/ha a 0,292 t/ha e $-0,359$ t/ha a $0,310 \mathrm{t} / \mathrm{ha}$, para o PE. De acordo com estas estimativas, as variedades WP 12 e MOROTI são as mais heteróticas entre as pertencentes ao Grupo [1]. No Grupo [2], as variedades mais heteróticas são CARIPEÑO DMR e TUXPEÑO AMARILLO (Tabela 3).

As estimativas de CGC para AP, AE e PE, para as variedades do Grupo [1] $\left(\mathrm{g}_{\mathrm{i}}\right)$, foram entre $-3,7 \mathrm{~cm}$ a $8,3 \mathrm{~cm},-4,5 \mathrm{~cm}$ a $11,2 \mathrm{~cm}$ e $-0,405 \mathrm{t} / \mathrm{ha}$ a $0,178 \mathrm{t} / \mathrm{ha}$, respectivamente. Para $P E$, as estimativas mais elevadas foram para as variedades WP 12 $(0,178 \mathrm{t} / \mathrm{ha})$, TAIÚBA $(0,176 \mathrm{t} / \mathrm{ha})$ e TAITINGA $(0,161 \mathrm{t} / \mathrm{ha})$. Entre estas, a variedade WP 12 apresentou estimativas de CGC positivas para AP e AE, com valores de $8,3 \mathrm{~cm}$ e 11,2 $\mathrm{cm}$, respectivamente (Tabela 3 ).

Os efeitos de CGC para as variedades do Grupo [2] $\left(g_{j}\right)$, para AP, AE e PE, ocorreram com estimativas entre $-8,8 \mathrm{~cm}$ a $7,3 \mathrm{~cm},-9,3 \mathrm{~cm}$ a $7,3 \mathrm{~cm} \mathrm{e}-0,341 \mathrm{t} / \mathrm{ha}$ a $0,300 \mathrm{t} / \mathrm{ha}$, respectivamente. Neste grupo, para $\mathrm{PE}$, destacaram-se as variedades CUPURICO DMR (0,300 t/ha) e TUXPEÑO AMARILLO (0,280 t/ha). Estas duas variedades apresentaram estimativas negativas de CGC para AP e AE (Tabela 3).

As estimativas de heterose ( $h$ ) e de percentagem de heterose (\%h) em relação a média das variedades progenitoras, para o PE foram entre $-0,86$ t/ha a 1,09 tha e $-26,9 \%$ a $36,5 \%$, respectivamente. Com percentuais superiores a $30 \%$, destacaram-se os hibridos TAITINGA $x$ CARIPEÑO DMR, WP $12 \times$ CARIPEÑO DMR e MOROTI $x$ TUXPEÑO AMARILLO (Tabela 4). Para heterose $\left(h_{s}\right)$ e percentagem de heterose $\left(\% h_{s}\right)$ em relação a variedade progenitora de maior média, também para o $\mathrm{PE}$, as estimativas foram de $-1,03 \mathrm{t} /$ ha a $0,85 \mathrm{t} / \mathrm{ha}$ e $-30,7 \%$ a $28,2 \%$, respectivamente. Com as maiores percentagens, destacaram-se os hibridos WP $12 \times$ AMARILLO DENTADO DMR, MOROTI $x$ TUXPEÑO AMARILLO e PORANGATU $x$ TUXPEÑO CREMA I (Tabela 4). 
Gorgulho (1997), em avaliação em Anhembi, SP, para AP, também verificou-se os maiores efeitos de variedades para a variedade WP 12, entre as variedades do Grupo [1], e para variedade PHILIPINE DMR, entre as variedades do Grupo [2]. Com os menores efeitos de variedades, também esteve a variedade TUXPEÑO AMARILLO. entre as variedades do Grupo [2]. Para AE, as variedades WP 12, Grupo [1], e PHILIPINE DMR Grupo [2], também estiveram entre as de maiores estimativas, e as variedades PORANGATU, Grupo [1] e TUXPEÑO AMARILLO, Grupo [2], também estiveram entre as de menores estimativas. Para o PE, em relação aos resultados verificados por Gorgulho (1997), a variedade TAITINGA, Grupo [1], e as variedades SUWAN 2 e TUXPEÑO AMARILLO, Grupo [2], também foram coincidentes entre as de maiores estimativas de efeitos de variedades. A concordância no comportamento das variedades, quanto aos seus efeitos de variedades, reforçam o potencial "per se" destas em proporcionar maiores ou menores estaturas e produtividades.

As maiores estimativas de CGC verificadas por Gorgulho (1997), em Anhembi. SP, para o caráter PE, foram para as variedades PORANGATU e IUBATÃ, no Grupo [1], e para as variedades TUXPEÑO CREMA I e CARIPEÑO DMR, no Grupo [2]. Estes resultantes não correspodem aos verificados neste estudo, onde as variedades com estimativas positivas foram a WP 12, TAIÚBA e TAITINGA, no Grupo [1], e as varidades CUPURICO DMR, TUXPEÑO AMARILLO e SUWAN 2, no Grupo [2]. Para os caracteres $A P$ e $A E$, as estimativas de CGC foram coincidentes quanto às variedades WP 12, Grupo [1], e TUXPEÑO AMARILLO, Grupo [2], referentes a maior e a menor estimativa, respectivamente. A falta de concordância quanto aos efeitos de CGC entre as avaliações, é indicativa de que em hibridos, as variedades não mantiveram seus comportamentos produtivos, o que deve estar relacionado a efeitos de interação híbridos $x$ ambientes, ressaltando-se as condições experimentais distintas nessas avaliações.

\section{Variedades selecionadas}

A partir das informações das análises dialélicas, e considerando-se principalmente os efeitos CGC para o PE, em ambos os grupos de variedades, as variedades TAITINGA, TAIÚBA e WP 12, do Grupo [1], e as variedades CUPURICO DMR e TUXPEÑO AMARILLO, do Grupo [2], foram selecionadas para participarem da etapa seguinte deste estudo. Infere-se que estas variedades concentram genes e efeitos genéticos favoráveis a produção e o desenvolvimento na condição de solo ácido, com toxidez devido ao alumínio e com limitações quanto a presença e disponibilidade de nutrientes. Para os caracteres $A P$ e $A E$, entre estas variedades, apenas a variedade WP 12 apresentou estimativas de 
CGC positivas, porém isto não compromete seu emprego em trabalhos de melhoramento. Ressalta-se que no estudo realizado por Gorgulho (1997), foram consideradas como variedades mais promissoras, em termos de CGC para produtividade, as variedades PORANGATU E SUWAN 2.

\subsubsection{Cruzamento dialélico (experimento 2)}

Esse experimento constituiu-se de um grupo de variedades progenitoras e seus hibridos. A seguir são apresentadas as médias, as análises das tabelas dialélicas, as estimativas de parâmetros e as variedades selecionadas para serem avaliadas em etapas seguintes deste estudo.

\section{Médias das variedades e híbridos}

Entre as variedades avaliadas "per se" e seus hibridos, as médias de AP e AE foram entre $165 \mathrm{~cm}$ a $214 \mathrm{~cm}$ e $88 \mathrm{~cm}$ a $128 \mathrm{~cm}$, respectivamente. As médias do experimento foram de $188 \mathrm{~cm}$ e $105 \mathrm{~cm}$ para $A P$ e $A E$, respectivamente. A PO variou entre 0,49 a 0,63. As médias de AP e AE da testemunha AG 6601 foram de $164 \mathrm{~cm}$ e 84 $\mathrm{cm}$, respectivamente, inferiores as médias verificadas entre os tratamentos. Já a testemunha AG 5011 mostrou médias AP e AE próximas a média do experimento, com valores de $185 \mathrm{~cm}$ e $108 \mathrm{~cm}$, respectivamente (Tabela 5).

As médias de IE variaram entre 0,53 a 0,97 e as médias de $P E$ variaram entre $2,64 \mathrm{t} / \mathrm{ha}$ a $5,11 \mathrm{t} / \mathrm{ha}$. O menor IE foi obtido pela variedade WP 12, a qual também apresentou o menor PE. O hibrido CMS 57NF x PMI 8701, com o maior IE, também obteve o maior PE, com 5,11 t/ha. Dentre as variedades avaliadas "per se" a PMI 8701 produziu acima de 4 tha. As demais variedades, com exceção a CMS 59 e WP 12, produziram acima de 3 tha. Entre os hibridos, muitos mostraram produtividades superiores a 4 t/ha, com destaque principalmente para os hibridos BR $105 \times$ PMI $9401 \mathrm{e}$ CMS 57NF XPMI 8701 com valores próximos as médias das testemunhas AG 6601 e AG 5011. Em relação à média geral do experimento, as testemunhas foram em torno 0,9 t/ha mais produtivas que os tratamentos (Tabela 5).

Ferreira (1999) com esse mesmo grupo de materiais, porém acrescido pelos hibridos reciprocos, em avaliação em Ribeirão Preto-SP, obteve médias de $A P$ e $A E$ superiores em $35 \mathrm{~cm}$ e $23 \mathrm{~cm}$, respectivamente, em relação as verificadas nesta avaliação. Em ambas as avaliações, as varie dades WP 12 e CMS 59 foram as de maior e menor médias de $A P$ e $A E$, respectivamente. As médias de PE verificadas por Ferreira 
(1999), foram superiores em 2,9 t/ha. Dentre as variedades mais produtivas, foram coincidentes as variedades CMS 58ND, AMARILLO DENTADO DMR, CMS 57NF e PMI 9401, além do híbrido BR 105 × PMI 9410. Entre as variedades com menor produtividade houve concordância quanto as varierdades WP 12 e CMS 59.

Em comparação aos resultados obtidos por Ferreira (1999), em avaliação em Rio Verde-GO, a média de PE na atual avaliação foi inferior em 2,78 t/ha. Os híbridos BR 105 x PMI 9401 e CMS 57NF x PMI 8701 e a variedade PMI 8701, com as maiores médias nesta avaliação, foram de desempenhos apenas satisfatórios em Rio Verde-GO.

As diferenças em relação as médias verificadas por Ferreira (1999), evidenciam as diferenças nas condições ambientais de avaliação. Ressalta-se que o ênfoque principal nas avaliações conduzidas por Ferreira (1999) foi quanto a resistência às doenças foliares, principalmente à ferrugem causada por Puccinia polysora. Portanto, as condições químicas do solo das áreas experimentais foram ao menos satisfatórias para o desenvolvimento e produção das plantas. Outras diferenças ambientais, como as relacionadas ao clima e a fatores fitossanitários, também podem ter contribuido para as diferenças nas médias.

\section{Análises de variância}

Os efeitos de variedades foram significativos para $A P, A E$ e $P E$. A heterose foi significativa para AP, AE e PE. Dos efeitos componentes da heterose, a heterose média foi significativa para $P E$ e a heterose específica foi significativa para $A E$. Já os efeitos de CGC foram significativos para AP, AE e PE (Tabela 6).

A significância da heterose média é indicativa da distinção no comportamento médio das variedades e dos híbridos, o que em termos de médias para o PE seriam 3,43 t/ha vs. 4,12 t/ha, para as variedades e híbridos, respectivamente. A não significância dos efeitos de heterose de variedades permitem relacionar os efeitos significativos de CGC principalmente aos efeitos de variedades. Neste sentido, tem-se indicios da predominância de efeitos genéticos aditivos. A heterose específica altamente significativa para $A E$, por sua vez, relaciona-se a um comportamento diferenciado deste caráter pelo menos em um híbrido específico, indicando a presença de efeitos genéticos de dominância.

Em avaliação em Rio Verde-GO, Ferreira (1999) verificou efeitos altamente significativos para os componentes da heterose, para o PE. Em avaliação em Ribeirão Preto-SP, os efeitos heterose de variedades foram altamente significativos. Em relação a estes resultados, a não significância de efeitos de heterose na atual avaliação pode estar 
relacionada aos efeitos ambientais, os quais promovem diferentes manifestações fenotipicas. Desta forma, a condição ambiental em Anhembi-SP pode ter sido restritiva a manifestação de efeitos de dominância, e por sua vez aos efeitos de heterose, descartando-se a possibilidade de falta de divergência genética entre as variedades.

\section{Estimativas de parâmetros}

As estimativas da média das variedades $(\mu)$, para os caracteres $A P, A E$ e $P E$ foram, respectivamente, $186,5 \mathrm{~cm}, 105,3 \mathrm{~cm}$ e $3,437 \mathrm{t} / \mathrm{ha}$. Para a AP, o efeito de variedades $\left(v_{i}\right)$ apresentou estimativas entre $-21,5 \mathrm{~cm}$ a $27,5 \mathrm{~cm}$. As estimativas para $A E$ foram entre $-11,3 \mathrm{~cm}$ a $22,7 \mathrm{~cm}$. As variedades WP 12, PMI 9401 e CMS 58ND mostraram estimativas positivas, enquanto as demais foram negativas. Os efeitos de variedades para o PE foram entre $-0,797 \mathrm{t} / \mathrm{ha}$ a $1,083 \mathrm{t} / \mathrm{ha}$, destacando-se as variedades PMI 8701 (1,083 t/ha), CMS 57NF (0,303 t/ha), PMI 9401 (0,273 t/ha) e CMS 58ND (0,243 t/ha). As variedades BR 105 e AMARILLO DENTADO DMR também apresentaram estimativas positivas, porém com baixos valores (Tabela 7 ).

A estimativa de heterose média $(\bar{h})$ para o PE foi de 0,683 t/ha. Os efeitos de heterose de variedades $\left(h_{i}\right)$, embora não significativos, apresentaram valores entre -0391 t/ha a 0,490 t/ha. As variedades CMS 59, IAPAR 51, ESALQ PB2 x ESALQ PB3 e BR 105, foram as de maior potencial heterótico (Tabela 7).

As estimativas de CGC $\left(g_{i}\right)$ para AP, AE e PE foram, respectivamente, entre $-6,7$ $\mathrm{cm}$ a $10,5 \mathrm{~cm},-6,4 \mathrm{~cm}$ a $9,7 \mathrm{~cm} \mathrm{e}-0,433 \mathrm{t} / \mathrm{ha}$ a $0,150 \mathrm{t} / \mathrm{ha}$. A variedade WP 12 obteve as maiores estimativas positivas para $A P$ e $A E$, além da maior estimativa negativa para o $P E$. As variedades PMI 8701 (0,150 t/ha), BR 105 (0,121 t/ha) e CMS 59 (0,106 t/ha), exibiram as estimativas mais favoráveis de CGC para o PE. Para AP e AE, estas variedades apresentaram estimativas negativas ou próximas a zero (Tabela 7).

A heterose $(h)$ em relação a média das variedades progenitoras variou entre zero a 2 t/ha. Já a heterose $\left(h_{s}\right)$ em relação a variedade progenitora de maior média ocorreu com valores entre $-0,71 \mathrm{t} / \mathrm{ha}$ a $1,98 \mathrm{t} / \mathrm{ha}$. Os híbridos CMS $59 \times$ WP 12, [CMS $59 \times(\mathrm{ESALQ}$ PB2 $\times$ ESALQ PB3)], CMS $59 \times$ IAPAR 51, AMARILLO DENTADO DMR x IAPAR 51, BR $105 \times$ PMI 9401, AMARILLO DENTADO DMR x IAPAR 51, CMS 57NF x IAPAR 51 e [AMARILLO DENTADO DMR $\times($ ESALQ PB2 $\times$ ESALQ PB3)] apresentaram as maiores estimativas, com valores próximos ou superiores a $1 \mathrm{t} / \mathrm{ha}$.

Ferreira (1999), em Ribeirão Preto-SP, também obteve as maiores estimativas de efeitos de variedades $\left(v_{i}\right)$ para as variedades CMS 58ND, CMS 57NF e PMI 9401, para o PE. Para a avaliação em Rio Verde-GO, também houve concordância quanto as 
variedades CMS 58ND e CMS 57NF. Tanto em Ribeirão Preto-SP, quanto em Rio VerdeGO, para o PE, Ferreira (1999) constatou as menores estimativas de $v_{i}$ referentes as variedades CMS 59 e WP 12. Também em ambos locais, para AP e AE, a variedade CMS 59 apresentou as menores estimativas de $v_{i}$ e a variedade WP 12 apresentou as maiores estimativas de $v_{\mathrm{i}}$. Estes resultados também são concordantes com os verificados na presente avaliação.

Em relação às estimativas de CGC para o PE, obtidas por Ferreira (1999), em Ribeirão Preto-SP, entre as maiores estimativas obteve-se concordância apenas quanto ao desempenho da variedade BR 105. Para a avaliação em Rio Verde, GO, entre as maiores estimativas, houve concordância quanto a variedade CMS 59. Em termos de AP e $A E$, as variedades CMS 59 e WP 12 obtiveram as menores e maiores estimativas de CGC, da mesma forma que os resultados verificados no presente estudo.

Para os valores de heterose para $P E$, em relação aos resultados de Ferreira (1999), houve concordância quanto aos bons desempenhos dos hibridos BR $105 \times$ IAPAR 51, CMS $59 \times$ WP 12, [CMS $59 \times$ (ESALQ PB2 × ESALQ PB3)], CMS $59 \times$ IAPAR 51 e CMS 59 x PMI 9401, na avaliação em Ribeirão Preto-SP. Para a avaliação em Rio VerdeGO, houve concordância quanto ao desempenho dos hibridos BR 105 × CMS 59, CMS 59 x WP 12, [CMS $59 \times($ ESALQ PB2 x ESALQ PB3)], CMS $59 \times$ IAPAR 51, CMS $59 \times$ PMI 9401 e [AMARILLO DENTADO DMR x (ESALQ PB2 × ESALQ PB3)].

\section{Variedades selecionadas}

A partir das análises dialélicas e considerando-se principalmente as estimativas de CGC para o PE, as variedades PMI 8701 e BR 105, com as maiores estimativas de CGC, foram selecionadas para participarem da etapa seguinte deste estudo. Estas foram consideradas de maior adaptação para a referida condição de solo, entre as que constituíram o grupo desse experimento. Deve-se lembrar que as variedades que constituiram este grupo foram selecionadas previamente por Ferreira (1999), entre 140 variedades avaliadas pelo NAP-Milho, dando-se ênfase à resistência à Puccinia polysora e produtividade. Portanto, além da adaptação à condição de solo ácido e baixa fertilidade, essas variedades apresentam outros atributos favoráveis. Entretanto, as variedades PMI 8701 e BR 105, escolhidas neste estudo, não constaram entre as cinco variedades escolhidas por Ferreira (1999), para fins de predição de compostos, com ênfase à resistência a $P$. polysora e produtividade. 


\subsubsection{Cruzamento "top cross" intragrupo (experimento 3)}

Esse experimento constituiu-se de um grupo de variedades e seus híbridos "topcrosses" intragrupo. A partir da avaliação desse experimento, são apresentadas as médias, as análises de variância de variedades e "topcrosses" intragrupo, as estimativas de parâmetros e as variedades selecionadas para participarem em etapas seguintes deste estudo.

\section{Médias das variedades e "topcrosses"}

Os valores das médias de AP e AE das variedades e respectivos "topcrosses", foram entre $151 \mathrm{~cm}$ a $210 \mathrm{~cm}$ e $77 \mathrm{~cm}$ a $134 \mathrm{~cm}$, respectivamente. A PO variou entre 0,47 a 0,65. A variedade GI 041 obteve a maior inserção de espiga, com $134 \mathrm{~cm}$. A testemunha AG 6601 obteve médias de AP e AE de $159 \mathrm{~cm}$ e $81 \mathrm{~cm}$, respectivamente, próximas as menores médias entre os tratamentos. As médias da testemunha AG 5011 foram de $176 \mathrm{~cm}$ e $102 \mathrm{~cm}$, respectivamente, sendo próximas as médias do experimento, sendo estas de $181 \mathrm{~cm}$ e $102 \mathrm{~cm}$, respectivamente (Tabela 9).

As médias de IE foram entre 0,49 a 1,05 e as médias de $P E$ foram entre 1,66 t/ha a 4,95 t/ha. A variedade GI 041 também apresentou os menores IE e PE. Para o PE, entre as 35 variedades avaliadas "per se", 16 superaram a média do experimento, destacando-se as variedades PMI 8701, BR 473, CMS 28 e BR 106 com produtividades próximas a 4 t/ha. Entre os 35 "topcrosses", 12 apresentaram produtividade superior a 4 t/ha. A maior produtividade foi obtida pelo "topcross" CMS $54 \times$ VT (4,95 t/ha), superando em 4,2 \% a testemunha AG 6601, sendo em torno de 5\% inferior a testemunha AG 5011 (Tabela 9).

Em avaliação realizada por Ferreira (1999), em Ribeirão Preto, para esse mesmo conjunto de tratamentos, a média de PE foi de 6,96 t/ha, superando a média desta avaliação em 3,41 t/ha. Houve concordância entre a avaliação realizada por Ferreira (1999) e a atual, quanto aos bons desempenhos da variedade BR 106 e dos "topcrosses" CMS $54 \times$ VT, CMS $28 \times V T, B R 106 \times V T$, [(ESALQ PB2 $\times$ ESALQ PB3) $\times$ VT] e PMI $9401 \times$ VT. Nos resultados verificados por Ferreira (1999), as médias de AP e AE superaram as médias desta avaliação em $48 \mathrm{~cm}$ e $31 \mathrm{~cm}$, respectivamente, sendo coincidentes os tratamentos com as maiores e menores.

Em avaliação em Rio Verde-GO, Ferreira (1999) verificou médias de PE de 6,73 t/ha, superiores as médias da atual avaliação em 3,18 t/ha. As variedades CMS 28, BR 106 e PMI 9401 e os "topcrosses" BR 106 × VT, CMS 53 × VT, CMS 54 × VT, CMS 57NF 
x VT, PMI $8701 \times$ VT e PMI $9401 \times$ VT estiveram entre os tratamentos de melhor produtividade em ambas as avaliações.

A acidez e a baixa fertilidade do solo na área experimental em Anhembi-SP, proporcionaram as principais diferenças entre as médias desta avaliação e as médias obtidas nas avaliações conduzidas por Ferreira (1999). Para essa condição de solo restritiva, as variedades com os melhores desempenhos podem estar relacionadas a uma melhor adaptação. Ressalta-se que as variedades que formaram este conjunto tratamentos, foram previamente selecionadas por Ferreira (1999) por suas resistências a Puccinia polysora, Phaeosphaeria maydis, Physopella zeae, Exserohilum turcicum, complexo enfazemento, além de caracteres agronômicos.

\section{Análises de variância}

Os efeitos de variedades apresentaram variação significativa para os caracteres $A P, A E$ e PE. Entre os componentes da heterose, a heterose média foi significativa para $A P, A E$ e $P E$, sendo o efeito de heterose de variedades significativo apenas para $A E$. Os efeitos de CGC foram significativos para AP, AE e PE (Tabela 10).

A significância do efeito de heterose média indica que o comportamento médio das variedades foi distinto do comportamento médio dos "topcrosses". Neste aspecto, as médias de AP, AE e PE dos "topcrosses" foram mais elevadas que as médias das variedades, tendo-se $185 \mathrm{~cm}$ vs. $177 \mathrm{~cm}, 105 \mathrm{~cm}$ vs. $99 \mathrm{~cm}$ e 3,83 t/ha vs. 3,28 t/ha, respectivamente. $O$ efeito significativo de heterose de variedades para $A E$, indica que ao menos uma variedade se distingue das demais quanto a heterose que proporciona aos hibridos em que participa. Para este caráter, a significância dos efeitos de CGC pode estar relacionada tanto aos efeitos de variedades quanto aos efeitos de heterose. Para AP e PE os resultados são no sentido de que os efeitos de CGC estão relacionados somente aos efeitos de variedades.

Considerando o PE, os resultados foram semelhantes aos verificados por Ferreira (1999), na avaliação em Rio Verde-GO, ou seja, com significância para efeitos de variedades e heterose média e não significância para o efeito de heterose de variedades. Em avaliação conduzida por Ferreira (1999) em Ribeirão Preto-SP, os efeitos de heterose de variedades foram significativos para $P E$ e não significativos para $A E$. Essas diferenças em resultados, da mesma forma que apontado para o experimento 2, podem estar relacionadas com a influência do ambiente na manifestação dos efeitos genéticos. Uma vez que os efeitos de heterose de variedades foram significativos em um ambiente, pressupõe-se que haja divergência em termos de freqüêcias alélicas, e portanto, a não 
significância em outros ambientes deve estar relacionada a não manifestação dos efeitos de dominância, visto que a divergência em freqüências alélicas deve ser a mesma. Ao contrário do verificado neste estudo, Brasl (1998) em avaliação em "safrinha", tendo-se estresse devido a irregularidade pluviométrica, verificou maior manifestação entre combinações heteróticas do que o verificado em avaliação em periodo normal de cultivo.

\section{Estimativas de parâmentros}

As estimativas das médias $(\mu)$ para os caracteres AP, AE e PE, foram $177,1 \mathrm{~cm}$; $99,2 \mathrm{~cm}$ e 3,27 tha, respectivamente. Os efeitos de variedades $\left(v_{i}\right)$ revelaram valores entre $-26,1 \mathrm{~cm}$ a $32,8 \mathrm{~cm},-22,2 \mathrm{~cm}$ a $35,0 \mathrm{~cm}$ e $-1,615 \mathrm{t} / \mathrm{ha}$ a 1,332 t/ha para $A P, A E \mathrm{e}$ PE, respectivamente. Para o PE, as variedades PMI 8701, BR 473, CMS 28, BR 106, PC 9405, CMS 4N, CMS 54 e BR 451, apresentaram os maiores efeitos de variedades, com valores superiores a 0,4 tha. Entre estas, a CMS 28 e a BR 451 apresentaram estimativas negativas para AP e AE, e a variedade PMI 8701 apresentou estimativa negativa para $A E$. As demais variedades, embora com estimativas positivas para estes caracteres, foram de baixa magnitude (Tabela 11).

Os efeitos de heterose de variedades $\left(h_{i}\right)$, apesar de não significativos para o PE, apresentaram estimativas de $-0,778$ tha a 0,972 t/ha. As variedades CMS 54, IAPAR 15, ESALQ PB2 $\times$ ESALQ PB3, CMS 53 e PIRANÃO VD 2 foram as mais heteróticas. As estimativas de heterose média $(\overline{\mathrm{h}})$ para $A P, A E$ e $P E$, respectivamente, foram $8,0 \mathrm{~cm}, 6,1$ $\mathrm{cm}$ e 0,566 t/ha (Tabela 11).

As variedades CMS 54, CMS 53, CMS 28, CMS 4N, BR 111 e CMS 57NF apresentaram as maiores estimativas de CGC $\left(g_{i}\right)$ para $\circ \mathrm{PE}$, superiores a $0,4 \mathrm{t} / \mathrm{ha}$. $\mathrm{A}$ maior e a menor estimativa, respectivamente, foi de 1,183 t/ha e $-0,894$ t/ha, para as variedades CMS 54 e CMS 4C. Para AP e AE, as estimativas de CGC foram entre $-12,7$ cm (CMS 59) a 17,8 cm (IAPAR 50) e $-22,6 \mathrm{~cm}$ (IAPAR 51) a 23,2 cm (WP 12), respectivamente. Entre as variedades com maior $C G C$ para o $P E$, as variedades $C M S 28$, CMS 53, CMS 57NF e PMI 8701 apresentaram estimativas negativas para AP e AE. A variedade CMS 54 apresentou estimativa negativa para AE (Tabela 11).

Entre as variedades com os maiores efeitos de variedades $\left(v_{i}\right)$ para o PE, BR 106, CMS 54 e PC 9405 também mostraram as maiores estimativas em avaliação realizada por Ferreira (1999), em Ribeirão Preto-SP. Também as variedades WP 12 e CMS 59, com maior e menor efeito de variedades para AP, respectivamente, foram as mesmas verificadas no presente estudo. Em avaliação realizada por Ferreira (1999) em Rio Verde$G O$, para o PE, entre as variedades com as maiores estimativas de $v_{i}$ também estiveram 
as variedades CMS 28, BR 106, PC 9405 e PMI 8701, sendo coincidentes em relação a este estudo.

Ferreira (1999), em avaliação em Ribeirão Preto-SP, também apontou as variedades CMS 28 e CMS 54 entre aquelas com os maiores efeitos de CGC ( $g_{i}$ ) para o PE. Referente a avaliação em Rio Verde-GO, as variedades CMS 53 e CMS 54 estiveram entre aquelas com as maiores estimativas de CGC para PE, também coincidentes com as verificadas neste estudo.

\section{Variedades selecionadas}

"Considerando principalmente as estimativas dos efeitos de CGC, as variedades CMS 53, CMS 28, CMS 54, CMS 4N, BR 111, SUWAN 2, PC 9405 e CMS 57NF foram selecionadas para participarem da etapa seguinte deste estudo. Supõe-se que estas variedades apresentam maior potencial para adaptação à condição de solo em que foram avaliadas. Ressalta-se, entretanto, que entre estas variedades, somente a variedade CMS 54 constou entre as cinco escolhidas por Ferreira (1999) para realizar a predição de compostos com vistas a resistência a doenças foliares e produção.

\subsubsection{Avaliação de variedades "per se" (experimento 4)}

Esse experimento, constituído de 50 variedades avaliadas "per se" reune materiais que participaram dos estudos de Mesquita Neto (2000) e de Narro Leon (1988), além de outros materiais constantes no banco de germoplasma do Departamento de Genética da ESALQ/USP, vistos como promissores. A partir da avaliação destas variedades são apresentadas as médias, as análises de variância e as variedades selecionadas para participarem da etapa seguinte deste estudo.

\section{Médias e análises de variância}

As médias de AP e AE foram entre $137 \mathrm{~cm}$ a $220 \mathrm{~cm}$ e $63 \mathrm{~cm}$ a $146 \mathrm{~cm}$, respectivamente (Tabela 12), sendo os efeitos das variedades significativos para ambos caracteres (Tabela 13). Os valores de PO foram de 0,45 a 0,67. Entre as variedades com menor estatura ocorreram a BA 166, SE 025, SE 030, BA 191, BA 035 e RN 003 . As variedades MEXCLA TROPICAL BLANCO, JAMAICA 10, BR 105 MI, VERA CRUZ 212, CMS 14, entre outras, destacaram-se pela elevada altura de inserção da espiga, como pode ser verificado nos valores de PO. As testemunhas AG 6601 e AG 5011 apresentaram médias de AP e AE inferiores as médias do experimento, sendo as médias da AG 6601 próxima as menores médias entre os tratamentos (Tabela 12). 
As médias de PE foram entre $1,45 \mathrm{t} /$ ha a $4,98 \mathrm{t} /$ ha (Tabela 12), com variação significativa entre variedades (Tabela 13). As variedades CMS 457, BRASIL 2294, JAMAICA 8, BLANCO CRISTALINO e BA 035 destacaram-se por apresentarem baixas médias de $P E$. Essas variedades também apresentaram $\mathrm{IE}$ baixos, e em alguns casos inferiores a 0,5. Já as variedades SE 036, BR 105 V, BA 115, SIKALQ, BA 191, BA 176, WP 32, PUEBLA GRUPO 27 e AL 009, todas com médias acima de 4 tha, foram as mais produtivas. Entre estas, a variedade AL 009 destaca-se pela elevada AE $(123 \mathrm{~cm})$, enquanto a variedade BA 191 destaca-se pela baixa AP $(156 \mathrm{~cm})$. As demais variedades apresentaram médias de AP e AE entre $169 \mathrm{~cm}$ a $193 \mathrm{~cm}$ e $84 \mathrm{~cm}$ a $116 \mathrm{~cm}$, respectivamente. O PE obtido pela variedade SE 036, superou a testemunha AG 6601 em 6,6\%, sendo pouco inferior ao obtido pela testemunha AG 5011 (Tabela 12).

Da mesma forma verificada em experimentos anteriores, muitos materiais apresentaram baixas produtividades. Este comportamento reflete a falta de adaptação destes à condição ambiental. Ressalta-se entre estas variedades a grande variação quanto a origem genética, local de origem, nivel de melhoramento, entre outros, como fatores responsáveis pelos comportamentos distintos.

Entre as variedades com melhores desempenhos, a variedade BA 115 consta entre as mais produtivas em estudo realizado por Santos et al. (1998), em condições de solo com limitação de fósforo. Também a variedade BR 105, de potencial reconhecido, foi uma das mais produtivas entre 28 variedades, na média de três locais, em estudo realizado por Santos et al. (1994). O bom desempenho da variedade SIKALQ em solo ácido, sintetizada pelo híbrido Sikuani $\times(E S A L Q P B 3 \times E S A L Q P B 2)$, pode ser relacionado ao potencial da variedade Sikuani, desenvolvida para adaptação a solos ácidos (CIMMYT, 1997).

\section{Variedades selecionadas}

Neste grupo de tratamentos, as variedades BA 115, BA 191, BA 176, SE 036, WP 32. PUEBLA GRUPO 27, AL 009, SIKALQ e MS 010, com as maiores médias de PE, e com médias de AP e AE em niveis satisfatórios, foram selecionadas para participarem da etapa seguinte deste estudo.

\subsubsection{Avaliação de variedades "per se" (experimento 5)}

Esse experimento, também constituído por 50 variedades avaliadas "per se", foi composto por materiais que participaram do estudo de Regitano Neto (1988), sendo 
resultantes do híbrido de germoplasma exótico com germoplasma adaptado, além de outros materiais disponiveis no banco de germoplasma do Departamento de Genética da ESALQ/USP, vistos como promissores. A partir da avaliação dessas variedades, são apresentadas as médias, as análises de varância e as variedades selecionadas para participarem da etapa seguinte deste estudo.

\section{Médias e análises da variância}

Os tratamentos deste experimento apresentaram médias de AP e AE com valores entre $149 \mathrm{~cm}$ a $192 \mathrm{~cm}$ e entre $73 \mathrm{~cm}$ a $116 \mathrm{~cm}$, respectivamente (Tabela 14). A variação devida às variedades foi significativa para ambos os caracteres (Tabela 15). As médias de $P O$ foram entre 0,47 a 0,63. A testemunha AG 6601 apresentou médias de $A P$ e $A E$ próximas as médias das variedades de menor altura. A testemunha AG 5011 apresentou médias mais elevadas, próximas as médias do experimento $(176 \mathrm{~cm}$ e $99 \mathrm{~cm}$, respectivamente) (Tabela 14$)$.

As médias de PE foram entre 2,22 t/ha a 4,47 tha (Tabela 14), com variação significativa (Tabela 15). As variedades CMS 39, CMS 463, (Cuba $173 \times$ B 73) x BR 106 e BS $16 \times$ BR 105 apresentaram as maiores produtividades, acima de 4 t/ha. As variedades CMS 39 e CMS 463 obtiveram desempenhos superiores a testemunha AG $6601(4,20$ t/ha) e próximos a AG 5011 (4,48 t/ha). A variação no IE foi entre 0,61 a 0,92, com valores coincidentes para as variedades de menor e maior PE. As testemunhas AG 6601 e AG 5011 apresentaram médias de IE de 0,81 e 0,74, respectivamente.

Muitas variedades apresentaram baixa média de PE, sugerindo pouca adaptação à condição ambiental. Da mesma forma que o experimento 4 , há uma grande variação quanto a origem genética, local de origem, nivel de melhoramento, entre outros, das variedades que constituem este grupo de tratamentos. Muitas destas variedades referemse a germoplasma exótico cruzado com germoplasma adaptado, tendo-se combinações diversas e desempenhos imprevisiveis. De modo positivo, destacaram-se as variedades [(CUBA $173 \times$ B 73) $\times$ BR 106] e BS $16 \times$ BR 105, indicando boas combinações, com $50 \%$ de germoplasma exótico e 50 \% de germoplasma adaptado. Regitano Neto (1998), em avaliação em Anhembi, na safra 1996/97, em solo corrigido, verificou bons desempenhos produtivos para as variedades [(CUBA $173 \times B$ 73) $\times$ BR 106]; [(CUBA $117 \times B$ 73) $\times$ BR 105]; [(CUBA $117 \times$ B 73) $\times$ BR 106]; [(CUBA $110 \times$ Mo 17) $\times$ BR 105] e [(REP. DOMINICANA $269 \times$ B 73) $\times$ BR 106].

Entre as variedades de melhor desempenho, a variedade CMS 39 tem sido mencionada em outros estudos, tanto por seu potencial produtivo quanto prolífico (Santos 
et al., 1994; Morello et al., 1994), inclusive em solos sob vegetação de "cerrado", com acidez e baixa fertilidade (Morello et al., 2000).

\section{Variedades selecionadas}

Entre as variedades deste grupo, as variedades CMS 39, CMS 463, [(CUBA $173 x$ B 73) $\times$ BR 106], BS $16 \times$ BR 105, [(CUBA $117 \times$ B 73) $\times$ BR 105], [(CUBA $117 \times B 73) \times$ BR 106], [(CUBA $110 \times$ MO 17) x BR 105], ANTIGUA $3 \times B R$ 106, IODENT $\times$ BR 106 e BS $29 \times$ BR 106, com as maiores médias de PE, e médias de AP e AE com valores satisfatórios, foram consideradas as de melhor desempenho e portanto, escolhidas para participarem da etapa seguinte deste estudo.

\subsection{Crescimento de radícula em solução nutritiva (experimento 6)}

Diversos fatores e suas relações, estão envolvidos na condição de solo em que foram conduzidos os experimentos 1 a 5 (Apêndice 1). Entre esses fatores consta 0 aluminio, porém seus efeitos ocorrem simultaneamente com outros, tais como deficiências em cálcio, magnésio, fósforo, potássio. Através da análise do crescimento de radicula em presença do aluminio, torna-se possivel mensurar efeitos especificos desse elemento. Empregando-se as variedades selecionadas nos experimentos da etapa anterior, conduzidos em solo ácido, a presente etapa objetivou discriminar entre essas variedades, quais possuem maior capacidade de crescimento de radicula em presença do aluminio. A partir da avaliação dessas variedades, são apresentadas as médias, as análises de variância e as variedades selecionadas para participarem da etapa seguinte.

O coeficiente de variação experimental (CV) para comprimento líquido de radícula (CL) foi de $11,5 \%$ (Tabela 16 ). Para as variáveis comprimento liquido de radicula relativo a testemunha tolerante (CLRTT) e comprimento liquido de radicula relativo a testemunha sensivel (CLRTS) os CV's foram de 12,6 \% e 15,7\%, respectivamente. Magnavaca (1982), Lopes et al. (1988) e Lima et al. (1992) verificaram valores com magnitudes próximas a estas.

Um aspecto de importância neste tipo de estudo, que auxilia na discriminação das variedades, é o comportamento contrastante entre testemunhas (Tabela 16). Neste sentido, as testemunhas empregadas nesta avaliação, os hibridos DINA 766 (tolerante) e MITLA 9560 (sensivel), apresentaram uma diferença média de $8,83 \mathrm{~cm}$, caracterizando padrões de tolerância e sensibilidade ao aluminio, previamente verificados por Furlani (1997). A testemunha tolerante foi superior à média do experimento em $5,53 \mathrm{~cm}$, 
enquanto a testemunha sensivel foi inferior à média do experimento em $3,30 \mathrm{~cm}$. Nenhuma das variedades superou a testemunha tolerante, porém algumas chegaram a valores de CL próximos. Já a testemunha sensivel foi superada por todas as variedades.

As amplitudes de valores de CL, CLRTT e CLRTS entre as variedades foram de $6,36 \mathrm{~cm}$ a 13,44 cm; 0,43 a 0,91 e 1,07 a 2,26, respectivamente (Tabela 16). Estas variações foram significativas, tendo-se portanto, distinção entre variedades (Tabela 17). O maior valor de $\mathrm{CL}$ foi de $13,44 \mathrm{~cm}$, obtido pela variedade TAITINGA, sendo 0,91 em CLRTT e 2,26 em CLRTS. As variedades [(CUBA 117x B 73) x BR 106] e MS 010 mostraram os menores $\mathrm{CL}$, em tomo de $6,4 \mathrm{~cm}$. Com valores de $\mathrm{CL}$ superiores a $10 \mathrm{~cm}$, destacaram-se as variedades TAITINGA, SIKALQ, TAIÚBA, BR 105, SUWAN 2, CMS 39, CMS 57NF, AL 009, CUPURICO DMR e CMS 53, em ordem decrescente de valores.

A avaliação do crescimento de radícula em presença do alumínio, tem sido amplamente utilizada para a seleção de individuos com capacidade de crescimento e desenvolvimento do sistema radicular na presença desse elemento (Rhue \& Grogan, 1977; Magnavaca 1982; Lima et al., 1992). A capacidade de crescimento passa a ser indicativa da presença de algum mecanismo de tolerância, podendo estar relacionado a exudação de ácidos orgânicos, imobilização do Al, efluxo do Al através da membrana plasmática, permeabilidade seletiva da membrana plasmática, entre outros (Kochian, 1995; Taylor, 1995). Tomando-se como referência a testemunha tolerante (DINA 766), cujo crescimento radicular obteve os maiores valores em ensaios comparativos com outros híbridos (Furlani, 1997), pressupõe-se que as variedades de maior CL podem ser portadoras de algum mecanismo de tolerância.

Entre as variedades com maior $C L$, esperava-se estar incluidas as variedades TAIÚBA e SIKALQ [Sikuani x (ESALQ PB2 x ESALQ PB3)]. Essas variededes já possuem um histórico quanto as suas adaptações a solos e soluções nutritivas com a presença de alumínio (Lima et al., 1992; Urrea-Gómez et al., 1996).

Considerando os resultados de crescimento de radícula em solução nutritiva e os resultados verificados nas avaliações anteriores em solo ácido, as variedades TAITINGA, SIKALQ, TAIÚBA, BR 105 , SUWAN 2, CMS 39, CMS 57NF, AL 009, CUPURICO DMR e CMS 53 foram selecionadas, sendo consideradas as mais adaptadas a condição de solo ácido, com menor sensibilidade aos efeitos do alumínio e da restrição nutricional. Este grupo de variedades foi empregado na etapa seguinte deste estudo. 


\subsection{Cruzamento dialélico e predição de compostos com adaptação a solo ácido}

As dez variedades escolhidas por suas adaptações às condições de solo ácido, verificadas nos ítens 4.1 e 4.2, nesta etapa foram avaliadas em cruzamento dialélico, conforme o modelo 4, análise If, de Gardner \& Eberhart (1966), associado ao modelo 1, método 4, de Griffing (1956), em dois níveis de ácidez no solo, correspondendo a dois experimentos (experimentos 7 e 8 , respectivamente). Os solos dessas áreas experimentais caracterizam-se pela acidez e baixa disponibilidade de nutrientes (Apêndice B). A área do experimento 7 corresponde ao solo original, o mesmo empregado nas avaliações dos experimentos 1 a 5 , no ítem 4.1. A área do experimento 8 também corresponde ao solo empregado nos experimentos 1 a 5 , no ítem 4.1, porém após uma calagem parcial, sendo portanto uma condição menos limitante, principalmente na camada de 0 a $20 \mathrm{~cm}$.

$\mathrm{Na}$ condução desses experimentos, no periodo de "safrinha", houve a necessidade de suplementação de água através de irrigação. Já as temperaturas ocorreram de forma a não limitar o desenvolvimento das plantas. Entre os fatores fitossanitários, destacaram-se a ocorrência de Spodoptera frugiperda (lagarta do cartucho) e doenças foliares causadas por Phaeosphaeria maydis e complexo enfezamento. Os niveis desses fatores foram considerados não limitantes aos objetivos deste estudo.

Tendo-se verificado um comportamento bastante contrastante entre as testemunhas utilizadas na avaliação de crescimento de radícula em solução nutritiva (experimento 6), nos experimentos desta etapa optou-se em empregar essas mesmas testemunhas, ou seja, o híbrido DINA 766 ( $\left.T_{1}\right)$ e o híbrido MITLA $9560\left(T_{2}\right)$. Curiosamente, esses híbridos contrastantes quanto aos efeitos do alumínio, em condição de solo ácido não corresponderam as expectativas. A testemunha MITLA 9560, sensivel ao alumínio, surpreendeu obtendo os maiores valores de AP, AE, CE, DE e PG (Tabelas 18, 19, 21 e 22). Esses resultados alertam para a falta de correlação entre tolerância ao alumínio e a adaptação a solo ácido, o que se justifica pela complexidade dos fatores envolvidos na condição de solo ácido, onde a presença do alumínio e sua toxidez é apenas um dos fatores.

Considerando a avaliação das variedades e seus híbridos, nesses dois experimentos e na média desses, são apresentados a seguir os resultados em termos de médias, análises dialélicas, estimativas de parâmetros e predição de compostos de variedades, abordando caracteres vegetativos e de produção. 


\subsubsection{Médias das variedades e híbridos}

São apresentadas a seguir as médias de caracteres vegetativos e de produção, considerando os experimentos 7 e 8 , respectivamente, e a média desses experimentos.

\section{- Caracteres vegetativos:}

Os caracteres AP e AE, no experimento 7 (Tabela 18), apresentaram valores de CV de $6,2 \%$ e $8,8 \%$, respectivamente. No experimento 8 (Tabela 19), os CV's foram de 5,0 $\%$ e 7,2 \%, respectivamente. Na análise conjunta (Tabela 20), os CV's foram de 5,8 \% e $8,0 \%$, respectivamente. Essas magnitudes estão dentro de limites normalmente verificados para esses caracteres em experimentação a campo, sendo valores médios segundo estudo de Scapin et al. (1995).

As médias de $A P$ e $A E$ foram entre $163 \mathrm{~cm}$ a $214 \mathrm{~cm}$ e $86 \mathrm{~cm}$ a $126 \mathrm{~cm}$, respectivamente, no experimento 7 , sendo a menor estatura para a variedade CMS 57NF e a maior estatura para o híbrido BR $105 \times$ AL 009. Os híbridos TAITINGA $\times$ CMS 39, TAIÚBA $\times$ AL 009 também estiveram entre os de maior altura, bem como a variedade CMS 39, com valores superiores a $210 \mathrm{~cm}$ e $115 \mathrm{~cm}$, para $A P$ e $A E$, respectivamente. Grande parte dos tratamentos superaram as alturas das testemunhas, principalmente a DINA 766 com valores de $175 \mathrm{~cm}$ e $90 \mathrm{~cm}$ para AP e AE, respectivamente (Tabela 18).

No experimento 8 , os valores de AP e $A E$ apresentaram variação entre $188 \mathrm{~cm}$ a $243 \mathrm{~cm}$ e $101 \mathrm{~cm}$ a $149 \mathrm{~cm}$, respectivamente. As menores alturas também foram verificadas na variedade CMS 57NF. O híbrido CMS $39 \times \mathrm{AL} 009$ foi o tratamento com as maiores alturas de AP e AE, embora outros, como BR $105 \times A L$ 009, SIKALQ $\times A L 009$, SUWAN $2 \times$ SIKALQ, TAITINGA $\times$ CMS 39 e as variedades CMS 39 e AL 009, também tenham obtido médias elevadas. As médias de $A P$ e $A E$ das testemunhas foram superadas pela maior parte dos tratamentos, com exceção para as variedades CMS 57NF e SIKALQ e para o híbrido CUPURICO DMR × CMS 53 (Tabela 19).

Considerando a análise conjunta, os valores médios de $A P$ e $A E$ foram entre $176 \mathrm{~cm}$ a $226 \mathrm{~cm}$ e $94 \mathrm{~cm}$ a $135 \mathrm{~cm}$, respectivamente. Com os menores valores, destacaram-se a variedade CMS 57NF e a testemunha DINA 766. Os tratamentos com as maiores médias foram CMS 39 e AL 009, entre as variedades, e TAITINGA $\times$ AL 009, TAITINGA $\times$ CMS 39, TAIÚBA × AL 009, SIKALQ × AL 009, CMS $39 \times A L 009$ e BR $105 \times$ AL 009, entre os 
híbridos. As duas testemunhas exibiram médias abaixo dos tratamentos, com exceção para a variedade CMS 57NF (Tabela 20).

Em média de tratamentos, os experimentos 7 e 8 (Tabelas 18 e 19, respectivamente) apresentaram diferenças em tomo $20 \mathrm{~cm}$ e $17 \mathrm{~cm}$ para $A P$ e $A E$, respectivamente. As maiores médias no experimento 8 podem ser relacionadas aos efeitos da calagem, reduzindo a concentração de alumínio e aumentando os teores de potássio, cálcio e magnésio, propiciando maior crescimento vegetativo. Esses mesmos efeitos podem ser verificados nas testemunhas, onde, em termos de AP, os híbridos DINA 766 e MITLA 9560 foram em torno de $25 \mathrm{~cm}$ mais altos no experimento 8. Uma possibildade é de que a melhor condição de solo no experimento 8 condicionou uma maior disponibilidade, absorção de nutrientes e translocação de fotossintetizados, resultando num maior crescimento e desenvolvimento, para um mesmo período vegetativo. Efeitos semelhantes a estes, em decorrência da calagem, também foram verificados por Naspolini et al. (1981). Gonzalez-Erico et al. (1979), em solos sob "cerrado", atribuíram o maior desenvolvimento vegetativo e produtivo com a realização da calagem, em decorrência da maior disponibilidade e absorção de cálcio e magnésio.

O número de dias para o florescimento masculino (DF), na média dos tratamentos, foi de 62 dias em ambos os experimentos (Tabelas 18 e 19). A testemunha DINA 766 atingiu o florescimento masculino com 62 dias no experimento 7 , e com 60 dias no experimento 8. Já a testemunha MITLA 9560, também com 62 dias da emergência ao florescimento no experimento 7, foi mais precoce no experimento 8, com média de 59 dias. Entre os tratamentos, as médias variaram entre 59 dias a 71 dias no experimento 7 , correspondendo as variedades SIKALQ e AL 009, respectivamente. No experimento 8, as médias foram entre 58 dias a 68 dias, também correspondendo as variedades SIKALQ e AL 009, respectivamente. Na média dos dois experimentos, obteve-se valores de 58 dias a 69 dias (Tabela 20).

Deve-se ressaltar que os experimentos foram conduzidos em "safrinha", o qual é caracterizado por menores temperaturas em relação ao período de safra. Desta forma, em época normal de cultivo, onde se tem temperaturas mais elevadas, o número de dias para se atingir o florescimento masculino pode ser inferior ao verificado.

As testemunhas DINA 766 e MITLA 9560, tolerante e sensivel ao alumínio, respectivamente, foram semelhantes em DFM, porém distintas quanto a AP e AE. A maior AP da testemunha MITLA 9560 foi verificada em ambos os experimentos. Uma possibilidade é de que este material, embora sensível ao alumínio, seja mais adaptado a 
outros fatores do solo, como a baixa disponibilidade de nutrientes, em relação ao híbrido DINA 766.

No experimento 7 (Tabela 18), o híbrido CUPURICO DMR x CMS 39 apresentou a maior \% AC, próxima a $5 \%$. Já no experimento 8 (Tabela 19), os tratamentos de maiores percentuais não chegaram a $2 \%$. Em ambos os experimentos muitos tratamentos apresentaram média de \% AC igual a zero. Na média dos experimentos (Tabela 20), 0 híbrido CUPURICO DMR x CMS 39, com 3,2 \%, obteve o maior valor de \% AC. O híbrido BR $105 \times$ AL 009 apresentou valor zero e muitos outros tratamentos, como a variedade TAIÚBA e os híbridos TAITINGA $\times$ CUPURICO DMR, TAITINGA x CMS 53, TAITINGA $\times$ CMS 39, TAITINGA $\times$ CMS 57NF, TAIÚBA $\times$ CUPURICO DMR, CUPURICO DMR $\times$ CMS 53, CUPURICO DMR x SUWAN 2, CUPURICO DMR × CMS 57NF, CMS $53 \times$ AL 009 , apresentaram valores inferiores a $0,5 \%$.

No experimento 7 (Tabela 18), muitos tratamentos superaram o valor de $10 \%$ de plantas quebradas (\% PQ), com o híbrido SIKALQ $\times$ CMS 39 atingindo 18,2\%. Nesse experimento, os híbridos TAIÚBA x CMS 57NF e CMS 53 × SUWAN 2 apresentaram os menores percentuais, em torno de 1,5\%. Também para \% PQ, no experimento 8 (Tabela 19), a variedade BR 105 e o híbrido SIKALQ x CMS 39 apresentaram valores próximos a $20 \%$, sendo que o híbrido TAIÚBA x CMS 39 atingiu 23,4\%. Muitos outros tratamentos apresentaram valores próximos a $10 \%$. Por outro lado, alguns tratamentos como as variedades CMS 53 e CMS 57NF, e os hibridos TAITINGA × CMS 53, TAITINGA $\times$ CMS $57 N F$, CMS $53 \times$ SUWAN 2 e SUWAN $2 \times$ CMS 57NF, apresentaram médias inferiores a $2 \%$. Na média dos experimentos (Tabela 20), com valores de \% PQ inferiores a $3 \%$, destacaram-se as variedades CMS 53 e CMS 57NF e os híbridos TAIÚBA $\times$ CMS 57 NF e SUWAN $2 \times$ CMS 57NF. Os híbridos SIKALQ x CMS 39 e TAIÚBA x CMS 39, superaram $15 \%$.

As médias de \% AC dos experimentos 7 e 8 (Tabelas 18 e 19) foram de 1,3\% e $0,4 \%$, respectivamente. Esses valores, a princípio, parecem pouco importantes, entretanto, quando se considera uma população com 50000 plantas/ha, esses percentuais correspondem a 690 plantas/ha e 245 plantas/ha, respectivamente. Da mesma forma, as médias de $\% P Q$, de $6,7 \%$ e $7,4 \%$ nos experimentos 7 e 8 , respectivamente (Tabelas 18 e 19), correspondem a 3355 plantas/ha e 3740 plantas/ha, respectivamente. Uma vez que grande parte das espigas de plantas acamadas ou quebradas se constituirão em perdas na colheita, tem-se uma acentuada redução na produtividade. Os valores de \% $A C$ e $\%$ PQ obtidos pelas testemunhas foram bastante 
inferiores a média de muitos tratamentos, em ambos os experimentos, o que ressalta a necessidade de melhoramento desses caracteres nas variedades em avaliação.

\section{- Caracteres de produção:}

Os CV`s para CE, DE, IE e PG, referentes ao experimento 7 (Tabeia 21), foram de $8,6 \% ; 4,6 \% ; 10,2 \%$ e 18,7\%, respectivamente. No experimento 8 (Tabela 22), os CV`s foram de $6,5 \% ; 4,2 \% ; 8,3 \%$ e 11,1\%, respectivamente. Já em análise conjunta (Tabela 23), os CV's foram de 7,6 \%; 4,5\%; 9,3\% e 15,1\%, respectivamente. Com exceção da variável PG no experimento 7 , com valor mais elevado, os demais valores correspondem a precisões experimentais em níveis satisfatórios. Sendo a produção um caráter mais sujeito a influências por fatores ambientais, e tendo-se uma condição de estresse por fatores de solo, CV`s mais elevados para esse caráter são esperados. Esses valores, conforme Scapin et al. (1995), são classificados como baixos e médios.

As médias de CE, no experimento 7, foram entre 12,5 cm (AL 009) a 15,5 cm (CMS 39), com uma amplitude de $2,3 \mathrm{~cm}$. Os híbridos TAITINGA $\times$ CMS 39, SUWAN $2 \times$ CMS 39, SUWAN $2 \times$ BR 105, SIKALQ x CMS 39 e BR $105 \times$ CMS 57NF, com valores superiores a $15 \mathrm{~cm}$, superam a média do experimento $(14,21 \mathrm{~cm})$ e a média da testemunha DINA $766(14,03 \mathrm{~cm})$. A variedade CMS 39 foi o tratamento de maior CE, superando também a testemunha MITLA $9560(15,37 \mathrm{~cm})$ (Tabela 21).

No experimento 8, as médias de CE foram entre $13 \mathrm{~cm}$ (AL 009) a 16,2 cm (CMS 39). Também os híbridos TAITINGA x CMS 39 e SUWAN 2 × CMS 39 apresentaram os maiores CE, superiores a $16 \mathrm{~cm}$. Novamente a variedade CMS 39 destacou-se, superando as testemunhas MITLA $9560(16,12 \mathrm{~cm})$ e DINA $766(15,37 \mathrm{~cm})$. Já a variedade $A L$ 009, da mesma forma que no experimento 7 , apresentou a menor média, com 1,85 cm abaixo da média do experimento (Tabela 22).

Em médias conjuntas, as variedades CMS 39 e AL 009 mantiveram-se com o maior e menor $C E$, respectivamente, tendo-se $3,1 \mathrm{~cm}$ de diferença entre essas. Os híbridos TAITINGA x CMS 39 e SUWAN 2 x CMS 39, com valores acima de $15,5 \mathrm{~cm}$, foram os de melhor desempenho. A variedade AL 009, para esse componente, foi a menos promissora (Tabela 23).

As médias para o DE, no experimento 7 (Tabela 21), situaram-se entre $3,6 \mathrm{~cm}(\mathrm{AL}$ 009) a $4,5 \mathrm{~cm}$ (CMS 57NF), com uma diferença de $0,9 \mathrm{~cm}$ entre esses tratamentos. $A$ variedade $A L 009$ foi o único tratamento com $D E$ inferior a $4 \mathrm{~cm}$. Os DE das testemunhas DINA 766 e MITLA 9560 foram de $4,2 \mathrm{~cm}$ e $4,4 \mathrm{~cm}$, respectivamente. No experimento 8 
(Tabela 22), as médias de DE foram entre 3,8 cm (BR 105 e AL 009) a 4,6 cm (TAIÚBA x CMS 53). As testemunhas apresentaram valores de 4,6 cm (DINA 766) e 4,4 cm (MITLA 9560). As médias conjuntas para DE (Tabela 23), situaram-se entre 3,7 cm (AL 009) e $4,5 \mathrm{~cm}$ (CMS 57NF). As testemunhas obtiveram valores próximos de $4,4 \mathrm{~cm}$.

Para o IE, as médias foram entre 0,91 (AL 009) a 1,18 (TAIÚBA x CMS 39), no experimento 7 (Tabela 21). As testemunhas apresentaram IE de 1,25 (DINA 766) e 1,13 (MITLA 9560). No experimento 8 (Tabela 22), as médias de IE foram entre 0,93 (AL 009 e TAITINGA x TAIÚBA) a 1,18 (TAIÚBA x CMS 39 e CMS $39 \times$ AL 009), sendo que as médias das testemunhas foram de 1,22 (DINA 766) e 1,14 (MITLA 9560). Em médias conjuntas dos experimentos (Tabela 23), os valores de IE variaram entre 0,92 (AL 009) a 1,18 (TAIÚBA x CMS 39), com médias de 1,23 e 1,13 para as testemunhas DINA 766 e MITLA 9560, respectivamente.

Para produtividade, em $P G$, as médias no experimento 7 foram entre 2,37 t/ha ( $A L$ 009) a 4,18 t/ha (BR $105 \times$ CMS 57NF). Entre as variedades, a CMS 39 com 4,08 t/ha foi a mais produtiva. Também os hibridos TAITINGA $\times$ SIKALQ, TAITINGA $\times$ CMS 39, CMS $53 \times$ BR 105, SUWAN $2 \times$ AL 009, SIKALQ x BR 105 e BR $105 \times$ AL 009, apresentaram bons desempenhos, com médias iguais ou superiores a 4 t/ha. Nesse experimento, as produtividades das testemunhas DINA 766 e MITLA 9560 foram de 3,82 t/ha e 4,83 t/ha, respectivamente, com uma diferença próxima de 1 t/ha. $A$ testemunha MITLA 9560 não foi superada em sua produtividade, entretanto muitos tratamentos obtiveram valores relativos acima de $80 \%$ (Tabela 21).

As médias de PG, no experimento 8, foram entre 3,20 t/ha ( $A L$ 009) a 5,20 t/ha (CMS $39 \times$ BR 105). Entre as variedades, a CMS 39 foi a mais produtiva $(4,78 \mathrm{t} / \mathrm{ha})$, com destaque também para as variedades TAITINGA, TAIÚBA, CMS 53, SIKALQ e CMS $57 N F$, com valores superiores a 4 t/ha. Outro destaque, além do híbrido CMS $39 \times B R$ 105, foi o hibrido TAITINGA x CMS 39, com 5,18 t/ha. Esses hibridos chegaram a valores de $96,3 \%$ e $96,8 \%$ em relação a testemunha MITLA 9560, a qual obteve 5,37 t/ha. A testemunha DINA 766 produziu 5,07 t/ha (Tabela 22).

Em médias conjuntas para o PG (Tabela 23), a variedade AL 009 produziu 2,78 tha, constituindo-se no tratamento menos adaptado. Já a variedade CMS 39, com 4,43 t/ha na média dos experimentos, e boas produtividades em ambos os experimentos, foi 0 principal destaque entre as variedades "per se". A maior média conjunta, com 4,63 t/ha foi obtida no híbrido TAITINGA $\times$ CMS 39. Boas produtividades também foram verificadas nos híbridos TAITINGA $\times$ SIKALQ, TAIÚBA x BR 105, CUPURICO DMR × CMS 39, CMS 
$53 \times$ BR 105, SUWAN $2 \times A L$ 009, SUWAN $2 \times$ CMS 57NF, SIKALQ $\times$ BR 105, BR $105 \times$ $A L 009$ e BR $105 \mathrm{~V} \times \mathrm{CMS} 57 \mathrm{NF}$, com valores superiores a 4,3 t/ha. Entre as testemunhas, a MITLA 9560, com média de 5,10 tha, foi a de melhor desempenho.

Para CE e DE, as diferenças entre os experimentos 7 e 8 (Tabelas 21 e 22, respectivamente), considerando as médias de tratamentos, foram de $0,64 \mathrm{~cm}$ e $0,07 \mathrm{~cm}$, respectivamente. Para O IE as médias dos experimentos foram as mesmas. Em PG, a diferença entre os experimentos foi de 0,81 t/ha. $O$ híbrido DINA 766 apresentou uma diferença de produtividade de 1,25 t/ha e o hibrido MITLA 9560 uma diferença de 0,54 tha. Essas diferenças, principalmente para o PG, evidenciam o efeito da melhor condição de solo no experimento 8 . Com a redução na saturação de alumínio de $64 \%$ para $45 \%$, em decorrência da calagem, Naspolini et al. (1981) verificaram aumentos na produtividade, sem haver alteração no indice de espigas. Os efeitos do alumínio, reduzindo a absorção de cálcio e magnésio e o transporte de potássio e fósforo, são apontados por Clark (1977); Gonzalez-Erico et al. (1979) e Bennet et al. (1986).

\subsubsection{Análises de variância}

$\mathrm{Na}$ análise conjunta dos experimentos 7 e 8 (Tabala 24), considerando-se os caracteres de produção (CE, DE e PG), os efeitos das interações com experimentos foram não significativos, com exceção para a interação heterose média $x$ experimento quanto ao PG. Nesta condição, a classificação dos efeitos é a mesma em ambos os experimentos, tendo-se a possibilidade de verificar a variação entre efeitos de tratamentos, variedades, heteroses e seus componentes, a partir da média dos experimentos. Os resultados a seguir abordam os referidos efeitos considerando-se a análise conjunta.

$\mathrm{Na}$ análise de variância conjunta, os efeitos de experimentos, tratamentos e variedades foram significativos para os caracteres $A P, A E, C E, D E$ e PG. Os efeitos de heterose foram significativos para AP, AE, DE, CE e PG. Entre os componentes da heterose, a heterose média foi não significativa apenas para $O \mathrm{CE}$. $A$ heterose de variedades apresentou efeitos significativos para todos os caracteres e a heterose especifica foi significativa para $A P, A E$ e $P G$. Os efeitos de CGC também foram significativos para todos os caracteres. Considerando-se o $P G$, exceto para interação heterose média $x$ experimentos, as demais interações foram não significativas (Tabela 24). 
A significância para os efeitos de variedades é indicativa da distinção entre estas em seus comportamentos "per se". Por sua vez os efeitos significativos de heterose podem ser relacionados a divergência entre variedades quanto as frequências alélicas, além da manifestação de efeitos genéticos de dominância. Entre os efeitos componentes da heterose, a significância para a heterose média indica que houve distinção entre a média das variedades e a média dos hibridos. Os efeitos de heterose de variedades, também siginificativos, refletem diferentes potenciais heteróticos entre estas. Já os efeitos significativos de heterose especifica relacionam-se a combinações genéticas especificas diferenciadas entre híbridos, em termos de desvio de heterose. A siginificância para o efeito de heterose especifica em hibridos intervarietais também foi relatada por Pandey et al. (1994) para produtividade em solos ácidos. Crossa et al. (1987) e Crossa et al. (1990), relataram a significância deste efeito para produtividade e altura da planta, e PérezVelásquez et al. (1995) relataram para produtividade, dias para florescimento e número de espigas por planta.

Para a CGC, os efeitos significativos indicam diferenças entre as variedades quanto as suas contribuições para os desempenhos dos hibridos em que participam. Uma vez que os efeitos de CGC são em função de efeitos de variedades e de efeitos de heterose de variedades, os quais também foram significativos para os caracteres $A P, A E, C E, D E$ e PG, presume-se estarem presentes tanto efeitos genéticos aditivos quanto efeitos genéticos de dominância. Neste sentido, em estudos em solos ácidos, Eleutério et al. (1988) e Duque-Vargas et al. (1994) verificaram igualdade de importância para estes dois tipos de efeitos genéticos na manifestação da produtividade em milho. Pandey et al. (1994), Borrero et al. (1995) e Salazar et al. (1997), consideraram os efeitos aditivos como os mais importantes. Já Ceballos et al. (1998) consideraram principalmente os efeitos epistáticos.

Em relação a ausência de efeitos significativos para grande parte das interações com experimentos, Ceballos et al. (1998) ressaltaram a existência de correlação entre desempenhos produtivos de progênies de milho em solos ácidos e solos não ácidos, também mencionada nos trabalhos de Duque-Vargas et al. (1994) e Borrero et al. (1995). 


\subsubsection{Estimativas de parâmetros}

Considerando-se as médias da análise conjunta, as estimativas das médias $(\mu)$ do grupo de variedades para os caracteres AP, AE, CE, DE e PG foram de 201,1 cm, 111,8 $\mathrm{cm}, 14,4 \mathrm{~cm}, 4,2 \mathrm{~cm}$ e 3,732 t/ha, respectivamente (Tabela 25).

Para o caráter $A P$, os efeitos de variedades $\left(v_{i}\right)$ foram entre $-25,6 \mathrm{~cm}$ a $21,8 \mathrm{~cm}$, referentes as variedades CMS 57NF e CMS 39, respectivamente. Em termos de $A E$, essas variedades também foram as de menor e maior estimativas, respectivamente, com $-18,3 \mathrm{~cm}$ e 18,2 cm (Tabela 25).

A maior estimativa de $v_{i}$ para $C E$ foi de $1,4 \mathrm{~cm}$, referente a variedade CMS 39. $O$ menor efeito foi verificado na variedade $A L 009$, com estimativa de $-1,6 \mathrm{~cm}$. Para o DE, a maior estimativa de $v_{i}$ foi verificada na variedade CMS $57 \mathrm{NF}$, com 0,27 cm, sendo a menor estimativa de $-0,5 \mathrm{~cm}$, também verificada na variedade AL 009. Para o PG, as estimativas de $v_{i}$ foram entre 0,698 t/ha a -0,947 t/ha, referentes a variedade CMS 39 e a variedade AL 009, respectivamente. Ainda com estimativas positivas de $v_{i}$ para PG, destacaram-se as variedades CMS 53, SIKALQ, CMS 57NF e TAITINGA, com valores superiores a 0,1 t/ha (Tabela 25).

Entre as variedades avaliadas "per se", a variedade CMS 39 foi a mais promissora quanto aos efeitos de variedade, sendo uma boa indicação para utilização em programa de seleção recorrente intrapopulacional. Entretanto, para os caracteres $A P$ e $A E$, as estimativas de $v_{i}$ foram relativamente elevadas, alertando para possibilidades de aumento na altura da planta e da espiga com a realização da seleção para produção, devido a correlação genética positiva entre esses caracteres (Hallauer \& Miranda Filho, 1988). Também as variedades CMS 57NF e SIKALQ, com estimativas negativas para AP e AE, e positivas para CE, DE e PG, são possibilidades para seleção recorrente intrapopulacional.

Entre os efeitos componentes da heterose, as estimativas de heterose média $(\overline{\mathrm{h}})$ para os caracteres AP, AE, CE, DE e PG foram de $5,3 \mathrm{~cm} ; 3,5 \mathrm{~cm} ; 0,1 \mathrm{~cm}, 0,06 \mathrm{~cm}$ e $0,338 \mathrm{t} / \mathrm{ha}$, respectivamente. As estimativas de heterose de variedades $\left(h_{\mathrm{i}}\right)$, para a $A P$, foram entre $-4,6 \mathrm{~cm}$ a $5,9 \mathrm{~cm}$, verificadas nas variedades CMS 53 e CMS $57 \mathrm{NF}$, respectivamente. Para $A E$, os efeitos de $h_{i}$ foram entre $-3,1 \mathrm{~cm}$ a $5,7 \mathrm{~cm}$, referentes as variedades CMS 53 e AL 009, respectivamente (Tabela 25).

Os maiores efeitos de $h_{i}$ para CE, DE e PG foram verificados na variedade AL 009, com valores de $0,7 \mathrm{~cm} ; 0,1 \mathrm{~cm}$ e 0,481 kg/ha, respectivamente. As variedades CMS $57 \mathrm{NF}$ e TAITINGA, respectivamente, apresentaram as menores estimativas de $h_{i}$ para CE e DE. 
Para o PG a variedade CMS 39 foi a menos heterótica com estimativa de -0,203 t/ha, sendo que esta variedade mosrou os maiorés efeitos de variedade para CE e PG. Por outro lado, a variedade AL 009 com os menores efeitos de variedade para CE, DE e PG, exibiu o maiores efeitos de heterose de variedades para esses caracteres (Tabela 25).

O comportamento da variedade AL 009, em termos de efeitos de variedades e efeitos de heterose de variedades, pode estar relacionado a um tamanho efetivo reduzido com possivel endogamia. Nesta situação, pode-se proporcionar maior divergência genética e por conseqüência heterose. Por outro lado, este conjunto gênico reduzido leva a um comportamento pouco favorável em se tratando do comportamento genotípico "per se". Quanto a variedade CMS 39, supõe-se um conjunto gênico amplo, que permite bons desempenhos "per se", porém com pouca divergência em relação as demais variedades, resultando em baixo efeito heterótico.

Os efeitos de CGC foram entre $-7,9 \mathrm{~cm}$ a $9,8 \mathrm{~cm}$ e $-7,8 \mathrm{~cm}$ a $13,1 \mathrm{~cm}$ para AP e $A E$, respectivamente. Os maiores efeitos para ambos os caracteres foram nas variedades AL 009, CMS 39 e BR 105. Já os menores efeitos foram nas variedades CMS 53 e CMS 57NF (Tabela 25).

Para o CE, as estimativas de CGC foram entre $-0,3 \mathrm{~cm}$ a $0,44 \mathrm{~cm}$. A variedade CMS 39 obteve a maior estimativa, com 0,44 cm, seguida pelas variedades BR 105 e SUWAN 2, com valores de $0,29 \mathrm{~cm}$ e $0,25 \mathrm{~cm}$, respectivamente. A estimativa menos favorável foi verificada na variedade CMS 53, com $-0,28 \mathrm{~cm}$. As estimativas de CGC para $D E$ foram entre $-0,09 \mathrm{~cm}$ a $0,09 \mathrm{~cm}$, sendo o menor valor referente a variedade $A L$ 009 e o maior valor referente a variedade CMS 57NF (Tabela 25).

Para o PG, os efeitos de CGC foram entre $-0,112 \mathrm{t} / \mathrm{ha}$ a $0,215 \mathrm{t} / \mathrm{ha}$. As variedades BR 105 e CMS 39 exibiram as maiores estimativas, com 0,215 t/ha e 0,145 t/ha, respectivamente. As variedades AL 009 e CMS 57NF também apresentaram estimativas positivas, porém baixas. A variedade CMS 53 foi a de estimativa menos favorável, seguida pelas variedades TAIÚBA e TAITINGA. Sendo a CGC em função dos efeito de variedade e de heterose de variedade, a estimativa obtida para variedade BR 105 deve estar relacionada principalmente ao efeito de heterose de variedade, uma vez que a estimativa do efeito de variedade foi negativa e próxima a zero. Já a variedade CMS 39 tem sua estimativa relacionada principalmente ao efeito de variedade, cujo valor foi bastante expressivo (Tabela 25).

As estimativas de heterose especifica $\left(s_{i i}\right)$ foram entre $-10,4 \mathrm{~cm}$ a $11,6 \mathrm{~cm}$ para $A P$, $-5,6 \mathrm{~cm}$ a $6,7 \mathrm{~cm}$ para $A E$ e $-0,472 \mathrm{~kg} / \mathrm{ha}$ a $0,457 \mathrm{~kg} / \mathrm{ha}$ para $P G$. Os hibridos TAIÚBA $x$ 
AL 009, TAITINGA x CMS 39, CMS 53 × SIKALQ, com as maiores estimativas de $s_{\mathrm{ii}}$ para $A P$, também apresentaram as maiores estimativas para $A E$. Também os híbridos TAITINGA $\times$ CMS 57NF, CMS $53 \times A L 009$ e CUPURICO DMR × AL 009, com as menores estimativas de $s_{i i}$ para $A P$, também o foram com relação a $A E$. $O$ híbrido TAITINGA x CMS 39, com 0,457 t/ha, foi o de maior estimativa de $s_{i i}$ para PG. Outros híbridos como TAITINGA $\times$ SIKALQ, SUWAN $2 \times$ CMS 57NF, CMS $53 \times$ BR 105, SUWAN $2 \times$ AL 009, CUPURICO DMR x CMS 57NF, TAIÚBA x CMS 53 e TAITINGA x SUWAN 2 também apresentaram estimativas de $s_{i i}$ superiores a 0,2 t/ha (Tabela 26).

Para o PG, a heterose em relação a média das variedades progenitoras (h), mostrou o valor máximo de 1,28 t/ha, no híbrido SUWAN 2 × AL 009, sendo este 43,0\% superior a média dessas variedades. Com valores acima de 0,9 t/ha, também se destacaram os híbridos BR $105 \times$ AL 009 e TAITINGA x AL 009. Em termos de heterose em relação à variedade progenitora de maior média $\left(h_{s}\right)$, também para o PG, o híbrido SUWAN $2 \times A L$ 009 obteve o maior valor, com 0,89 t/ha, sendo este $27,1 \%$ superior em relação a média da variedade SUWAN 2, de maior média (3,33 t/ha). Os híbridos BR $105 \times A L 009$, SIKALQ $\times$ BR 105, TAIÚBA x BR 105 e CMS 53 × BR 105, com estimativas acima de 0,5 t/ha, obtiveram as maiores estimativas (Tabela 27 ).

A magnitude da heterose (h) é diretamente proporcional as diferenças nas frequências alélicas das variedades nos locos onde há algum grau de dominância (Falconer \& Mackay, 1996). Portanto, havendo dominância direcional, quanto maior a diversidade genética maior será a heterose esperada. Neste sentido, as variedades que constituem os híbridos SUWAN $2 \times$ AL 009, BR $105 \times$ AL 009 e TAITINGA $\times$ AL 009, os mais heteróticos em relação as médias das variedades progenitoras, podem ser relacionadas por suas divergências genéticas.

$\mathrm{Na}$ heterose $\left(h_{\mathbf{s}}\right)$ em relação a variedade progenitora de maior média, tem-se valores positivos quando os alelos favoráveis, que ocorrem em baixa freqüência na variedade de maior média, ocorrem em alta freqüência na variedade de menor média. Tendo-se uma complementação entre as variedades, o híbrido resultará em um acúmulo de alelos favoráveis, superando a freqüência destes na variedade de maior média (Souza Jr., 1985). Nesse aspecto, pressupõe-se ter ocorrido complementariedade entre as variedades que participaram dos híbridos SUWAN $2 \times A L$ 009, BR $105 \times$ AL 009, SIKALQ x BR 105, TAIÚBA x BR 105 e CMS 53 x BR 105, com heteroses acima de 0,5 t/ha em relação a melhor variedade progenitora. 


\subsubsection{Predição de médias de compostos}

Miranda Filho \& Chaves (1991) demonstraram que os termos de maior importância na discriminação entre médias de compostos de mesmo tamanho $k$ são aqueles em função dos efeitos de variedades $\left(v_{i}\right)$ e efeitos de heterose de variedades $\left(h_{i}\right)$, e seus respectivos coeficientes. Desta forma, 0 indice $I_{i}$, definido por estes autores, permite a seleção das variedades genitoras de maior contribuição para a média de um composto de tamanho $\mathrm{k}$.

Os valores do indice $I_{i}$ de variedades para o caráter $P G$, considerando as estimativas de efeitos de variedades $\left(v_{i}\right)$ e efeitos de heterose de variedades $\left(h_{i}\right)$ a partir das médias conjuntas, foram entre $-0,233$ tha a 0,248 t/ha, para $k=2 ;-0,102$ t/ha a $0,142 \mathrm{t} / \mathrm{ha}$, para $\mathrm{k}=3 ;-0,056 \mathrm{t} / \mathrm{ha}$ a $0,098 \mathrm{t} / \mathrm{ha}$, para $\mathrm{k}=4 \mathrm{e}-0,035 \mathrm{t} / \mathrm{ha}$ a $0,075 \mathrm{t} / \mathrm{ha}$, para $k=5$. As variedades CMS 39, BR 105, SIKALQ, CMS 57NF e TAITINGA, nesta ordem, obtiveram os maiores valores para $o$ índice $I_{i}$, sendo escolhidas para formar 0 conjunto básico $(k=5)$, com o qual foram feitas as predições de médias de compostos de tamanhos $k=2$ a $k=5$. As médias preditas servem de base para a escolha do tamanho e do composto mais adequado para os objetivos do projeto(Tabela 28).

Um aspecto de importância no emprego do índice $l_{i}$ é quanto a viabilização das predições. Tendo-se dez variedades em hibridos dialélicos, seriam possiveis $2^{n}-(n+1)$ compostos (Vencovsky \& Miranda Filho, 1992), ou seja, 1013 compostos. A realização das predições para esse número de compostos poderia proporcionar muitas possibilidades para a seleção, porém, torna-se uma tarefa extremamente dispendiosa, principalmente quando vários caracteres devem ser preditos. Neste sentido, o emprego do indice $l_{i}$ evita a realização de todas as predições, sem que haja o descarte de variedades relevantes para o composto a ser formado. Este índice também foi empregado por Basso (1999) para seleção de populações, visando a predição de médias de compostos com ênfase para resistência ao complexo de enfezamento e produtividade.

Considerando as variedades TAITINGA, SIKALQ, CMS 39, BR 105 e CMS 57NF, e seus hibridos, as médias preditas de compostos, para o caráter $P G$, foram entre 3,71 t/ha a 4,39 t/ha. Entre os compostos de tamanho $k=2$, a maior média foi predita para 0 composto TAITINGA x CMS 39, com 4,39 t/ha. Também destacou-se o composto SIKALQ $x$ CMS 39, com 4,20 t/ha. Para compostos com tamanho $k=3$, destacaram-se os compostos TAITINGA $\times$ SIKALQ $\times$ CMS 39, com 4,30 t/ha, e TAITINGA $\times$ CMS $39 \times$ BR 105, com 4,21 t/ha. Com tamanho $k=4$, o composto TAITINGA $\times$ SIKALQ $\times$ CMS $39 \times B R$ 
105, com 4,22 t/ha, foi o de maior média, seguido pelo composto SIKALQ $\times$ CMS $39 \times B R$ $105 \times$ CMS 57NF, com 4,17 tha. O composto amplo, envolvendo as cinco variedades, TAITINGA $\times$ SIKALQ $\times$ CMS $39 \times$ BR $105 \times$ CMS 57NF, obteve média de 4,13 t/ha (Tabela 29).

As médias preditas de AP e AE foram entre $189 \mathrm{~cm}$ a $219 \mathrm{~cm}$ e $101 \mathrm{~cm}$ a $125 \mathrm{~cm}$, respectivamente. A maioria das médias para \% AC foi próxima a $1 \%$. Já as médias para $\% P Q$ variaram entre $3,8 \%$ a $13,6 \%$. As médias para $D F$ foram entre 59 dias a 67 dias, sendo o composto CMS $39 \times \mathrm{BR} 105$ o mais tardio. Em termos de $\mathrm{CE}$, as médias variaram entre $14,47 \mathrm{~cm}$ a $15,54 \mathrm{~cm}$, com uma amplitude pouco superior a $1 \mathrm{~cm}$, sendo o composto TAITINGA $\times$ CMS 390 de maior CE. As médias para DE foram entre $4,17 \mathrm{~cm}$ a $4,40 \mathrm{~cm}$ e as médias de IE foram entre 0,98 a 1,12 (Tabela 29).

O composto TAITINGA $\times$ CMS $57 N F$ foi o de menor média para $A P, A E$ e $\% P Q$, com uma das menores médias para $\% A C$ e foi o de maior média para $D E$. Nestes aspectos, é um composto com possibilidades para conciliar várias características agronômicas favoráveis, porém obteve a menor média para $\circ \mathrm{PG}$, entre todos os compostos preditos. Já o composto TAITINGA $\times$ CMS 39 obteve as maiores médias para $P G$ e $C E$, entretanto também obteve as maiores predições para $A P$ e $A E$, embora estas não tenham sido em magnitudes que inviabilizem o composto. De modo geral, entre os compostos com as maiores médias preditas para PG, as médias preditas para os demais caracteres não se constituiram em limitações à sintese dos mesmos (Tabela 29).

Dois aspectos de importância na definição do composto a ser sintetizado, são a média e a variabilidade genética. Para ० PG, a diferença entre o composto de maior média, de tamanho $k=2$ (TAITINGA $\times$ CMS 39), e o composto de maior amplitude da base genética, de tamanho $k=5$ (TAITINGA $\times$ SIKALQ $\times$ CMS $39 \times$ BR $105 \times$ CMS 57NF), foi de $0,26 \mathrm{t} / \mathrm{ha}$. Em um programa de seleção recorrente a longo prazo, haja vista a pouca diferença na média, justifica-se a opção pelo composto mais amplo, onde é esperada uma maior expressão de variabilidade a ser explorada ao longo dos ciclos de seleção. Entretanto, objetivando-se compostos com maior facilidade para homogeneização, outras opções podem ser consideradas, como compostos com tamanhos $k=2$ (TAITINGA $\times$ CMS 39 ou SIKALQ $\times$ CMS 39) ou k=3 (TAITINGA $\times$ SIKALQ $\times$ CMS 39 ou SIKALQ $\times$ CMS $39 \times$ $B R$ 105), tendo-se médias entre as maiores preditas e disponibilidade de variabilidade. 


\subsection{Consideraçōes finais}

A medida que novas áreas de cultivo vão se tornando áreas convencionais, com o emprego de corretivos e sucessivas adubações, existe a tendência de melhoria na condição química destes solos, onde fatores como acidez e disponibilidade de nutrientes tornam-se menos limitantes. Entretanto, nos seus primeiros anos de cultivo, como ocorre nas mais recentes fronteiras agrícolas do Brasil, fatores como acidez e disponibilidade de nutrientes são de grande importância, restringindo drasticamente o desenvolvimento e a produtividade do milho. Em vista da necessidade de tomar estas áreas viáveis para a exploração agrícola, além de práticas de manejo do solo, faz-se fundamental dispôr de cultivares com adaptação, ou seja, com produção em nivel satisfatório mesmo sob estresse. Diante das possibilidades de expansão agrícola, bem como da cultura do milho, o desenvolvimento de cultivares adaptados a solos ácidos é uma demanda a permanecer longo periodo.

Sendo a disponibilidade de recursos genéticos um fator fundamental para o sucesso de um programa de melhoramento, no início deste programa, estrategicamente, buscou-se verificar a adaptação do maior número de materias possível, avaliando-se uma ampla coleção de germoplasma. Participaram destas avaliações germoplasma adaptado, exótico, acessos e cultivares, os quais denominou-se de variedades. Destaca-se a oportunidade em se iniciar um programa a partir da avaliação de um número tão expressivo de materiais. Adicionalmente, entre os cinco experimentos que constituiram esta etapa inicial, três experimentos seguiram delineamentos genéticos, possibilitando a seleção das variedades mais adaptadas, tanto por seus desempenhos "per se", quanto em híbridos.

Um aspecto fundamental na execução deste trabalho foi a disponibilidade de área experimental com as características químicas de solo pretendidas, ou seja, com acidez, presença de alumínio e baixa saturação de bases. A abertura de uma nova área experimental na Fazenda Anhembi - ESALQ/USP, portanto com solo original, viabilizou as avaliações a campo. Nestas avaliações, embora caracterizando-se o solo como ácido e com baixa disponibilidade de nutrientes, tem-se um complexo de fatores, composto pelos elementos que compõem o solo e suas interações. Portanto, ao discriminar variedades com adaptação a solo ácido, realizou-se a discriminação de variedades com adaptação a um complexo de fatores de solo. 
Um dos elementos de maior importância na composição do complexo de fatores de solo é o alumínio, o qual tem ocorrência comum em solos ácidos, embora em níveis variáveis. Com a avaliação de variedades em solução nutritiva contendo alumínio, propiciou-se condição para verificar, entre as variedades com adaptação a solo ácido, quais apresentam algum mecânismo de tolerância a esse elemento. As variedades tolerantes dispõem de um atributo a mais, que em certas condições de solo pode ser fundamental. Ressalta-se, portanto, a importância da avaliação da tolerância ao alumínio, simultaneamente às avaliações a campo

A partir das avaliações iniciais em solo ácido e, posteriormente, em solução nutritiva com alumínio, discriminou-se dez variedades de maior adaptação. Um aspecto relevante, a partir de então, foi conhecer o potencial genético dessas variedades. Tendose como objetivo verificar o potencial para sintese de compostos, empregou-se 0 esquema de híbrido dialélico. Essas variedades e seus hibridos foram avaliadas em dois niveis de acidez no solo, buscando-se verificar a ocorrência de interações e, por conseqüência, a necessidade de compostos distintos para cada nivel de acidez. Como as interações não ocorreram, com base na média desses experimentos, selecionou-se as variedades de maior potencial. Neste aspecto, o emprego do índice $\mathrm{I}_{\mathrm{i}}$, sugerido por Miranda Filho \& Chaves (1991), foi de grande utilidade na escolha das variedades, com as quais realizou-se as predições, evitando-se realizar predições envolvendo as dez variedades. Ao final deste trabalho, o qual iniciou com 158 variedades e 122 hibridos, a identificação das variedades CMS 39, BR $105 \mathrm{~V}$, SIKALQ, CMS 57NF e TAITINGA, com potencial para a sintese de compostos com adaptação a solo ácido, é um indicativo de avanço e de possibilidades de êxito na condução deste programa. 


\section{CONCLUSÕES}

A partir dos resultados verificados neste estudo, obteve-se as seguintes conclusões:

a) Existem diferenças entre as variedades de milho avaliadas em solo ácido, dentro de cada conjunto, quanto ao potencial de adaptação para a referida condição de solo;

b) Os efeitos de variedades foram mais importante do que os efeitos de heterose de variedades na expressão da capacidade geral de combinação, verificados nos experimentos 1, 2 e 3, para os caracteres altura da planta, altura da espiga e peso de espigas;

c) As variedades avaliadas em solução nutritiva, quanto ao crescimento de radícula, previamente selecionadas em solo ácido, apresentam diferentes niveis de tolerância aos efeitos do aluminio;

d) A calagem parcial, reduzindo a acidez e aumentando a disponibilidade de nutrientes, foi responsável por significativos incrementos nas médias dos caracteres altura da planta, altura da espiga, comprimento da espiga, diâmetro da espiga e peso de grãos;

e) Os efeitos significativos de heterose e seus componentes, para os caracteres altura da planta, altura da espiga, comprimento da espiga, diâmetro da espiga e peso de grãos, verificados na análise dialélica conjunta dos experimentos 7 e 8 , atestam que, além da divergência genética já constatada entre variedades, houve também uma forte expressão de dominância na condição de solo ácido;

f) Os efeitos significativos de capacidade geral de combinação para os caracteres altura da planta, altura da espiga, comprimento da espiga, diâmetro da espiga e peso de 
g) grãos, verificados na análise dialélica conjunta dos experimentos 7 e 8 , foram relacionados aos efeitos de variedades e/ou efeitos de heterose de variedades;

h) As variedades CMS 39, CMS 57NF e SIKALQ, com os maiores valores para os efeitos de variedades para o peso de grãos, destacam-se com elevado potencial para emprego em programas de seleção recorrente intrapopulacional;

i) O cruzamento TAITINGA x CMS 39, com a maior estimativa de heterose específica para peso de grãos corrigido, é uma possibilidade de padrão heterótico para emprego em programas de seleção recorrente interpopulacional;

j) Entre as variedades avaliadas em cruzamento dialélico, nos experimentos 7 e 8 , as variedades CMS 39, BR $105 \mathrm{~V}$, SIKALQ, CMS 57NF e TAITINGA, apresentam elevado potencial como parentais na sintese de compostos de milho com adaptação a solo ácido. 


\section{REFERÊNCIAS BIBLIOGRÁFICAS}

ALLARD, R.W. Principles of plant breeding. New york: John Wiley \& Sons, 1960. 485p.

ANDERSON, E.; CUTLER, H.C. Races os Zea mays: I. Their recognition and classification. Ann. Missouri Botanic Garden, v.29, p.69-88, 1942.

BASSO, C.M. Sintese de compostos de milho (Zea mays L.) com resistência ao "complexo de enfezamento" Piracicaba, 1999.126p. Tese (Doutorado) - Escola Superior de Agricultura "Luiz de Queiroz"/USP.

BENNET, R.J.; BREEN, C.M.; FEY, M.V. Aluminum toxicity and induced nutrient disorders involving the uptake and transport of $\mathrm{P}, \mathrm{K}, \mathrm{Ca}$ and $\mathrm{Mg}$ in Zea mays $\mathrm{L}$. South African Journal Plant Soil, v.3, p.11-17, 1986.

BORRERO, J.C.; PANDEY, S.; CEBALLOS, H.; MAGNAVACA, R.; BAHIA FILHO, A.F.C. Genetic variances for tolerance to soil acidity in a tropical maize population. Maydica, v.40, p.283-288, 1995.

BRASIL, E.M. Variabilidade genética, heterose e efeitos de endogamia em populações de milho (Zea mays L.). Goiânia, 1998. 186p. Tese (Doutorado) - Universidade Federal de Goiás.

CEBALLOS, H.; PANDEY, S.; NARRO, L.; PEREZ-VELASQUeZ, J.C. Additive, dominant, and epistatic effects for maize grain yield in acid and non-acid soils. Theoretical and Applied Genetics. v.96, p.662-668, 1998. 
CENTRO INTERNACIONAL DE MELHORAMENTO DE MILHO E TRIGO-CIMMYT. Development of new stress-resistant maize genetics resources (UNDP Project GLO/90/003). Maize Program Special Report. México, D.F.: CIMMYT, 1997. $210 p$.

CHANG, T.T. Availability of plant germoplasm for use in crop improvement. In: STALKER, H.T.; MURPHY, J.P., ed. Plant breeding in the 1990s. Melksham: Redwood Press, 1992. p.17-35.

CHAVES, L.J.; MIRANDA FILHO, J.B. Predicting variety composite means without diallel crossing. Revista Brasileira de Genética, v.20, p.501-506, 1997.

CLARK, R.B. Effect of aluminum on growth and mineral elements of Al-tolerant and Alintolerant corn. Plant and Soil, v.47, p.653-662, 1977.

CLARK, R.B.; BROWN, J.C. Differential phosphorus uptake by phosphorus-stressed corn inbreds. Crop Science, v.14, p.505-508, 1974.

COLEMAN, R.A.; THOMAS, G.W. The basic chemistry of soil acidity. In: PEARSON, R.W.; ADAMS, F. ed., Soil acidity and liming. Madison, American Society of Agronomy, 1967. p.1-41.

COMSTOCK, R.E.; ROBINSON, H.F. The components of genetic variance in populations of biparental progenies and their use in estimating the average degree of dominance. Biometrics, v.4, p.254-266, 1948.

CROSSA, J.; GARDNER, C.O.; MUMM, R.F. Heterosis among populations of maize (Zea mays L.) with different levels of exotic germplasm. Theoretical and Applied Genetics, v.73, p.445-450, 1987.

CROSSA, J.; TABA, S.; WELLHAUSEN, E.J. Heterotic pattern among Mexican races of maize. Crop Science, v.30, p.1182-1190, 1990. 
DELHAIZE, E.; RYAN, P.R. Aluminum toxicity and tolerance in plants. Plant Physiology, v.107, p.315-321, 1995.

DOWSWELL, C.R.; PALIWAL, R.L.; CANTRELL, R.P. Maize in the third world. Boulder: Westview Press, 1996. 267p.

DUQUE-VARGAS, J.; PANDEY, S.; GRANADOS, G.; CEBALLOS, H.; KNAPP, E. Inheritance of tolerance to soil acidity in tropical maize. Crop Science, v.34, p.5054, 1994.

EBERHART, S.A.; GARDNER, C.O. A general model for genetic effects. Biometrics, v. 22, p.864-881, 1966.

EBERHART, S.A.; HARRINSON, M.N.; OGADA, F.A. Comprehensive breeding system. Der Züchter, v.37, p.169-174, 1967.

ELEUTÉRIO, A.; GAMA, E.E.G.; MORAIS, A.R. Capacidade de combinação e heterose em híbridos intervarietais de milho adaptados às condições de cerrado. Pesquisa Agropecuária Brasileira, v.23, p.247-253, 1988.

EMBRAPA. Relatório Técnico Anual do Centro Nacional de Pesquisa de Milho e Sorgo 1985-1987. Sete Lagoas: EMBRAPA/CNPMS, 1991. 170p.

EMBRAPA. Relatório Técnico Anual do Centro Nacional de Pesquisa de Milho e Sorgo 1980-1984. Sete Lagoas: EMBRAPA/CNPMS, 1986. 190p.

EMBRAPA. Relatório técnico anual do Centro Nacional de Pesquisa do Cerrado 19761977. Planaltina: EMBRAPA/CPAC, 1978. 183p.

FALCONER, D.S.; MACKAY, T.F.C. Introduction to quantitative genetics. Edinburgh:Longman Group Ltd, 1996. 464p. 
FERREIRA, D.F.; REZENDE, G.D.S.P.; RAMALHO, M.A.P. Na adaptation of Griffing's method IV of complete diallel cross analysis for experiments repeated in several environments. Revista Brasileira de Genética, v.16, p.357-366, 1993.

FERREIRA, J.M. Análise genética e sintese de populações visando resistência à ferrugem (Puccinia polysora Underw.) em milho (Zea mays L.). Piracicaba, 1999. 230p. Tese (Doutorado) - Escola Superior de Agricultura "Luiz de Queiroz"/USP.

FOY, C.D. Effects of aluminum on plant growth. In: CARSON, E.W., ed. The plant root and its environment. Charlottesville: Virginia University Press, 1974. p.601642.

FOY, C.D. Physiological effects of hydrogen, aluminum and manganese toxicities in acid soil. In: ADAMS, F., ed. Soil acidity and liming. Madison: Soil Science Society of America, 1984. p.57-97.

FOY, C.D. Plant adaptation to acid, aluminum - toxic soils. Communications in Soil Science and Plant Analysis, v.19, p.959-987, 1988.

FOY, C.D. Soil chemical factors limiting plant root growth. In: HATFIELD, J.L. \& STEWART, B.A., ed. Limitations to plant root growth. New York: SpringerVerlag, 1992. p.97-149.

FOY, C.D.; CHANEY, R.L.; WHITE, M.C. The physiology of metal toxicity in plants. Annual Review of Plant Physiology, v.29, p.511-566, 1978.

FURLANI, P.R. Tolerância de cultivares de milho ao aluminio. In: SEMINÁRIO SOBRE A CULTURA DO MILHO "SAFRINHA", 3. Assis, 1995: Instituto Agronômico de Campinas, 1995. p.71-75.

FURLANI, P.R. Toxicidade de aluminio e manganês em plantas. In: RAIJ, B. van; BATAGLIA, O.C.; SILVA, N.M. coord. Acidez e calagem no Brasil. Campinas: Sociedade Brasileira de Ciência do Solo, 1983. p.79-85. 
FURLANI, P.R.; BERTON, R.S. Atividade de cálcio e alumínio e desenvolvimento radicular. In: SEMINÁRIO SOBRE O USO DE GESSO NA AGRICULTURA, 2., Uberaba, 1992. Anais. Uberaba:IBRAFOS, 1992. p.121-138.

GALVÃO, J.D.; SILVA, J.C. Herança da tolerância ao alumínio na variedade de milho "piranão". Revista Ceres, v.25, p.71-78, 1978.

GARDNER, C.O. Simplified methods for estimating constants and computing sums of squares for a diallel cross analysis. Fitotecnia Latinoamericana, v.4, p.1-12, 1967.

GARDNER, C.O. Teoría de genética estadística aplicable a las medias de variedades, sus cruces y poblaciones afines. Fitotecnia Latinoamericana, v.2, p.11-22, 1965.

GARDNER, C.O.; EBERHART, S.A. Analysis and interpretation of the variety cross diallel and related populations. Biometrics, v.22, p.439-452, 1966.

GERALDI, I.O.; MIRANDA FILHO, J.B. Adapted models for the analysis of combining ability of varieties in partial diallel crosses. Revista Brasileira de Genética, v.11, p. $419-430,1988$.

GONZALEZ-ERICO, E.; KAMPRATH, E.J.; NADERMAN, G.C.; SOARES W.V. Effect of depth of lime incorporation on the growth of corn on na oxisol of central Brasil. Soil Science Society American Journal, v.43, p.1155-1158, 1979.

GOODMAN, M.M. A brief survey of the races of maize and current attempts to infer racial relationships. In: WALDEN, D.B., ed. Maize breeding and genetics, New York: John Wiley and Sons, 1978. p.143-158.

GOODMAN, M.M. História e origem do milho. In: PATERNIANI, E.; VIÉGAS, G.P., ed. Melhoramento e produção do milho. Campinas: Fundação Cargill, 1987. v.1, p.3-38. 
GOODMAN, M.M.; BROWN, W.L. Races of maize. In: SPRAGUE, G.F.; DUDLEY, J.W., ed. Corn and corn improvement. Madison: American Society of Agronomy, 1988. p.33-79.

GOODMAN, M.M.; SMITH, J.S.C. Botânica. In: PATERNIANI, E.; VIÉGAS, G.P., ed. Melhoramento e produção do milho. Campinas: Fundação Cargill, 1987. v.1, p.41-78.

GORGULHO, E.P. Avaliação de variedades de milho (Zea mays L.) sob dois esquemas de cruzamento: dialélico parcial e "top-cross" intergrupos. Piracicaba, 1997. 94p. Tese (Doutorado) - Escola Superior de Agricultura "Luiz de Queiroz"/USP.

GRANADOS, G.; PANDEY, S.; CEBALLOS, H. Response to selection for tolerance to acid soils in a tropical maize population. Crop Science, v.33, p.936-940, 1993.

GRIFFING, B. Concept of general and specific combining ability in relation to diallel crossing systems. Australian Journal of Biological Science, v.9, p.463-493, 1956.

HALE, M.G.; ORCUTT, D.M. The physiology of plants under stress. New York: John Wiley \& Sons, 1987. 206p.

HALLAUER, A.; MIRANDA FILHO, J.B. Quantitative genetics in maize breeding. 2.ed. Ames: lowa State University Press, 1988. 486p.

JENKINS, M.T. Methods of estimsting the performance of double crosses in corn. Journal of American Society of Agronomy, v.26, p.199-204, 1934.

JINKS, J.L.; HAYMAN, B.I. The analysis of diallel crosses. Maize Genetics Cooperation News Letter, v.27, p.48-54, 1953. 
KAMPRATH, E.J. Exchangeable aluminum as a criterion for liming leached mineral soils. Soil Science Society of America Proceedings, v.34, p.252-254, 1970.

KEMPTHORNE, O.; CURNOW, R.N. The partial diallel cross. Biometrics, v.17, p.229250, 1961.

KIM, S.K.; HALLAUER, A.R. Agronomic traits of the tropical and subtropical inbreds in lowa. Plant varieties and seeds, v.2, p.85-91, 1989.

KINJO, T. Conceitos de acidez de solos. In: RAIJ, B. van; BATAGLIA, O.C.; SILVA, N.M. coord. Acidez e calagem no Brasil. Campinas: Sociedade Brasileira de Ciência do Solo, 1983. p.23-32.

KINRAIDE, T.B. Identify of the rhizotoxic aluminum especies. In: WRIGHT, R.J. Plantsoil interaction at low pH. Dordrecht: Kluwer Academic Publishers, 1991. p.717728.

KOCHIAN, L.V. Cellular mechanisms of aluminum toxicity and resistance in plants. In: JONES, R.L.; SOMERVILLE, C.R.; WALBOT, V., ed. Annual Review of Plant Physiology and Plant Molecular Biology, v.46, p.237-260, 1995.

LIMA, M.; VITTI, P.; GALLO, P.B. Populações de milho: características agronômicas e tecnológicas. Bragantia, v.47, p.55-62, 1988.

LIMA, M.; FURLANI, P.R.; MIRANDA FILHO, J.B. Divergent selection for aluminum tolerance in a maize (Zea mays L.) population. Maydica, v.37, p.123-132, 1992.

LIMA, M.; MIRANDA FILHO, J.B.; FURLANI, P.R. Diallel cross among inbred lines of maize differing in aluminum tolerance. Revista Brasileira de Genética, v.18, p.579-584, 1995.

LIMA, M.; VITTI, P.; GALLO, P.B. Populações de milho: Características agronômicas e tecnológicas. Bragantia, v.47, p.55-62, 1988. 
LOPES, A.S. Manual de fertilidade do solo. São Paulo:ANDA/POTAFOS, 1989. $153 p$.

LOPES, A.S. Solos sob cerrado. Piracicaba., Instituto da Potassa e Fosfato, 1983. $162 p$.

LOPES, M.A.; MAGNAVACA, R.; BAHIA FILHO, A.F.C.; GAMA, E.E.G. Avaliação de populações de milho e seus cruzamentos para tolerância à toxidez de alumínio em solução nutritiva. Pesquisa Agropecuária Brasileira, v.22, p257-263, 1987.

LUTZ JUNIOR, J.A; HAWKINS, G.W.; GENTER, C.F. Differencial response of corn inbreds and single crosses to certain properties of an acid soil. Agronomy Journal, v.63, p.803-805, 1971.

MAGALHÃES, A.C.; SILVA, W.J. Determinantes genético-fisiológicos da produtividade do milho. In: PATERNIANI, E.; VIÉGAS, G.P., ed. Melhoramento e produção do milho. Campinas: Fundação Cargill, 1987. v.2, p.423-450.

MAGNAVACA, R. Genetic variability and the inheritance of aluminum tolerance in maize (Zea mays L.). Nebraska, 1982. 135p. Tese (Doutorado) - University of Nebraska.

MALAVOLTA, E.; KLIEMANN, H.J. Desordens nutricionais no cerrado. Piracicaba: Instituto da Potassa e Fosfato, 1985. 136p.

MALAVOLTA, E.; VITTI, G.C.; OLIVEIRA, S.A. Avaliação do estado nutricional das plantas: princípios e aplicações. Piracicaba: Instituto da Potassa e Fosfato, 1989. 201p.

MESQUITA NETO, D.R. Valor genético de populações de milho para resistência a doenças. Piracicaba, 2000. 211p. Tese (Doutorado) - Escola Superior de Agricultura "Luiz de Queiroz"/USP. 
MIRANDA FILHO, J.B. Analysis of diallel tables with reciprocal crosses. Revista Brasileira de Genética, v.18, p.633-637, 1995.

MIRANDA FILHO, J.B. Breeding methodologies for tropical maize. In: BRANDOLINI, A.; SALAMINI, F. ed. Breeding strate gies for maize production improvement in the tropics. Firenze: Food and Agriculture Organization of United Nations, 1985. p.175-206.

MIRANDA FILHO, J.B.; CHAVES, L.J. Analysis of diallel crosses with $F_{2}$ generations. Revista Brasileira de Genética, v.19, p.127-132, 1996.

MIRANDA FILHO, J.B.; CHAVES, L.J. Procedures for selecting composites based on prediction methods. Theoretical and Applied Genetics, v.81, p.265-271, 1991.

MIRANDA FILHO, J.B.; GERALDI, I.O. An adapted model for the analysis of partial diallel crosses. Revista Brasileira de Genética, v. 7, p.677-688, 1984.

MIRANDA FILHO, J.B.; VENCOVSKY, R. The partial circulant diallel cross at the interpopulational level. Genetics and Molecular Biology, v.22, p.249-256, 1999.

MIRANDA, L.T.; FURLANI, P.R.; MIRANDA, L.E.C.; SAWAZAKI, E. Genetics of environmental resistance and super genes: latente aluminum tolerance. Maize Genetics Cooperation News Letter, v. 58, p.46-48, 1984.

MORAIS, A.R.; OLIVEIRA, A.C.; GAMA, E.E.G.; SOUZA JUNIOR, C.L. A method for combined analysis of the diallel crosses repeated in several environments. Pesquisa Agropecuária Brasileira, v.26, p.371-381, 1991.

MOREIRA JUNIOR, W.N. Componentes de heterose a partir de "topcrosses" intergrupos em linhagens de milho (Zea mays L.). Goiânia, 1995. 114p. Dissertação (Mestrado) - Universidade Federal de Goiás. 
MORELLO, C.L.; SANTOS, M.X.; RAMALHO, M.A.P.; OLIVEIRA, A.C. Efeito da densidade de plantas na seleção massal para prolificidade em milho (Zea mays L.). Ciência e Prática, v. 18, p.357-364, 1994.

MORELLO, C.L.; PELUZIO, J.M.; COELHO, R.M.S.; SANTOS, M.X. Populações de milho (Zea mays L.) com adaptação às condições de Terras Altas no Estado do Tocantins. ACTA Amazonica, 2000. (no prelo)

NARRO LEON, T. Sintese de populações de milho com resistência a doenças por virus e phytoplasmas-espiroplasmas. Monografia (Pós-Doutorado), Piracicaba, 1998. 80p. - Escola Superior de Agricultura "Luiz de Queiroz"/USP.

NASPOLINI FILHO, V.; BAHIA FILHO, A.F.C.; VIANNA, R.T.; GAMA, E.E.G.; VASCONCELOS, C.A.; MAGNAVACA, R. Comportamento de linhagens e de hibridos simples de milho (Zea mays L.) em solos sob vegetação de cerrado. Ciência e Cultura, v.33, p.722-727, 1981.

NASS, L.L.; MIRANDA FILHO, J.B. Inbreeding depression rates of semi-exotic maize (Zea mays L.) populations. Brazilian Journal of Genetics, v.18, p.585-592, 1995.

NASS, L.L.; SANTOS, M.X.; PATERNIANI, E. Importância das coleções de milho e perspectivas de coleta. In: WALTER, B.M.T.; CAVALCANTI, T.B. Fundamentos para a coleta de germoplasma vegetal. Brasilia: Embrapa-Recursos Genéticos e Biotecnologia, 2000.

OLMOS, J.I.L.; CAMARGO, M.N. Ocorrência de aluminio tóxico nos solos do Brasil, sua caracterição e distribuição. Ciência e Cultura, v.28, p.171-180, 1975.

PACHECO, C.A.P. Avaliação de progênies de meios irmãos da população de milho CMS 39 em diferentes condições de ambiente-2 ciclo de seleção. Lavras, 1987. 109p. Tese (Mestrado) - Escola Superior de Agricultura de Lavras. 
PANDEY, S.; CEBALLOS, H.; GRANADOS, G.; KNAPP, E. Developing maize that tolerates aluminum toxiv soils. In: EDMEADES, G.E.; DEUTSCH, J.A. ed. Stress tolerance breeding:Maize that resists insects, drought, low nitrogen and acid soils. México, D.F.: CIMMYT, 1994a. p.85-92.

PANDEY, S.; CEBALLOS, H.; MAGNAVACA, R.; BAHIA FILHO, A.F.C.; DUQUEVARGAS, J.; VINASCO, L.E. Genetics of tolerance to soil acidity in tropical maize. Crop Science, v.34, p.1511-1514, 1994b.

PARENTONI, S.N.; FRANÇA, G.E.C.; GAMA, E.E.G.; GUIMARÃES, P.E.O.; LOPES, M.A.; SANTOS, M.X. Avaliação de estresses multiplos (toxidez de alumínio em solução nutritiva, produtividade em solo ácido e eficiência na utilização de fósforo) em linhagens de milho. In: CONGRESSO NACIONAL DE MILHO E SORGO, 21., Londrina, 1996. Resumos. Londrina:ABMS/IAPAR, 1996. p. 162.

PATERNIANI, E. Maize breeding in the tropics. Critical Reviews in Plant Sciences, v.9, p.125-154, 1990.

PAVAN, M.A.; BIGHAM, F.T. Toxicity of aluminum to coffe seedlings grown in nutrient solution. Soil Science Society of America Journal, v.46, p.993-997, 1982.

PÉREZ-VELÁSQUeZ, J.C.; CEBALlOS, H.; PANDEY, S.; DíAZ-AMARIS, C. Analysis of diallel crosses among colombian landraces and improved populations of maize. Crop Science, v.35, p.572-578, 1995.

RAIJ, B.van. Avaliação da fertilidade do solo. Piracicaba: Instituto da Potassa e Fosfato, 1981. 142p.

RAMALHO, M.A.P., SANTOS, J.B.; ZIMMERMANN, M.J.O. Genética quantitativa em plantas autógamas: aplicações ao melhoramento do feijoeiro. Goiânia: Editora Universidade Federal de Goiás, 1993. 271p. 
REGITANO NETO, A. Incorporação de germoplasma exótico de milho (Zea mays L.). Piracicaba, 1998. 133p. Tese (Doutorado) - Escola Superior de Agricultura "Luiz de Queiroz"IUSP.

REGITANO NETO, A.; NASS, L.L.; MIRANDA FILHO, J.B. Potential of twenty germplasms to improve Brazilian maize architecture. Brazilian Journal of Genetics, v.20, p.691-696, 1997.

RHUE, R.D.; GROGAN, C.O. Screening corn for Al tolerance using different $\mathrm{Ca}$ and Mg concentrations. Agronomy Journal, v.69, p.755-760, 1977.

RHUE, R.D.; GROGAN, C.O.; STOCKMEYER, E.W.; EVERETT, H.L. Genetic control of aluminum tolerance in corn. Crop Science, v.18, p.1063-1067, 1978.

RITCHIE, G.S.P. The chemical behaviour of aluminum, hydrogen and manganese in acid soils. In: ROBSON, A.D. Soil acidity and plant growth. Marrickville: Academic Press Australia, 1989. 306p.

ROY, A.K.; SHARMA, A.; TALUKDER, G. Some aspects of aluminum toxicity in plants. The Botanical Review, v.54, p.145-178, 1988.

SALAZAR, F.S.; PANDEY, S.; NARRO, L.; PEREZ, J.C.; CEBALLOS, H.; PARENTONI, S.N.; BAHIA FILHO, A.F.C. Diallel analysis of acid-soil tolerant and intolerant tropical maize populations. Crop Science, v.37, p.1457-1462, 1997.

SANTOS, M.X.; MIRANDA FILHO, J.B. Genetic potential of two Brazilian races of maize (Zea mays L.) for breeding purposes. Journal of Genetics and Breeding, v.46, p.83-90, 1992.

SANTOS, M.X.; CARVALHO, H.W.L.; LEITE, C.E.P.; ANDRADE, R.V.; VASCONCELLOS, C.A. Evaluation and selection of tropical maize (Zea mays L.) accessions in low-fertility soils with phosphorus limitations. Plant Genetic Resources Newsletter, v.113, p.17-21, 1998. 
SAWAZAKI, E.; FURLANI, P.R. Genética da tolerância ao aluminio em milho cateto. Bragantia, v.46, p.269-278, 1987.

SCAPIM, C.A.; CARVALHO, C.G.P.: CRUZ, C.D. Uma proposta de classificação dos coeficientes de variação para a cultura do milho. Pesquisa Agropecuária Brasileira, v.30, p.683-686, 1995.

SIBOV, S.T.; GASPAR, M.; SILVA, M.J.; OTTOBONI, L.M.M.; ARRUDA, P.; SOUZA, A.P. Two genes control aluminum tolerance in maize: Genetic and molecular mapping analyses. Genome, v.42, p.475-482, 1999.

SILVA, W.J. Seleção de milho tolerante ao aluminio. In: REUNIÃO BRASILEIRA DE GENÉTICA REGIONAL DE SÃO PAULO, 13., Jaboticabal, 1979. Anais. Jaboticabal:UNESP, 1979. p.107-113.

SOUZA JUNIOR, CL.; ZINSLY, J.R. Relative genetic potential of brachytic maize (Zea mays L.) varieties as breeding populations. Revista Brasileira de Genética, v.8, p.523-533, 1985.

SPRAGUE, G.F. Corn and corn improvement. Madison: American Society of Agronomy, 1977. 774p.

SPRAGUE, G.F.; TATUM, L.A. General vs. Specific combining ability in single crosses of com. Journal of the American Society of Agronomy, v.34, p.923-932, 1942.

TABA, S. Maize germplasm:its spread, use and strategies for conservation. In: TABA, S., ed. Maize genetic resources: maize program special report. México, 1995. p.7.-58.

TAYLOR, G.J. Overcoming barriers to understanding the cellular basis of aluminum resistance. Plant and Soil, v.171, p.89-103, 1995. 
TAYLOR, G.J. The physiology of aluminum tolerance in higher plants. Communications in Soil Science and Plant Analysis, v. 19, p.1179-1194, 1988.

URREA-GÓMEZ, R.; CEBALLOS, H.; PANDEY, S.; BAHIA FILHO, A.F.C.; LEÓN, L.A. A greenhouse screening technique for acid soil tolerance in maize. Agronomy Journal, v.88, p.806-812, 1996.

VENCOVSKY, R. Alguns aspectos teóricos e aplicados relativos a cruzamentos dialélicos de variedades. Piracicaba, 1970. 59p. Tese (Livre-Docência) - Escola Superior de Agricultura "Luiz de Queiroz"IUSP.

VENCOVSKY, R. Análise de cruzamentos dialélicos entre variedades pelo método de Gardner \& Eberhart. Relatório Científico do Instituto de Genética, ESALQ/USP, v.3, p.99-111, 1969.

VENCOVSKY, R.; BARRIGA, P. Genética biométrica no fitomelhoramento. Ribeirão Preto: Sociedade Brasileira de Genética, 1992. 496p.

VENCOVSKY, R.; MIRANDA FILHO, J.B. Determinação do número de possiveis compostos e pares de compostos. Relatório Científico Instituto de Genética, ESALQ/USP, v.6, p.120-123, 1972.

VENCOVSKY, R.; VELLO, N.A. Estimativa da média e do grau de homogeneização de um composto de variedades. Ciência e Cultura, v.21, p.233-234, 1969.

VENCOVSKY, R.; ZINSLY, J.R.; VELLO, N.A.; GODOY, C.R.M. Predição da média de um caráter quantitativo em compostos de variedades e cruzamentos de compostos. Fitotecnia Latinoamericana, v.8, p.25-28, 1973.

WAGATSUMA, T. Characterization of absorption sites aluminum in the roots. Soil Science and Plant Nutrition, v.29, p.499-515, 1983. 
TABELAS 
Tabela 1. Médias das variedades e hibridos para altura da planta (AP) e altura da espiga (AE), em $\mathrm{cm}$; posição relativa da espiga (PO); indice de espigas (IE); peso de espigas (PE), em t/ha; percentagem do peso de espigas em relação a testemunha $1\left(\% T_{1}\right)$ e percentagem do peso de espigas em relação a testemunha $2\left(\% \mathrm{~T}_{2}\right)$, e coeficientes de variação experimental (CV). Experimento 1, Anhembi, SP, 1997/98.

\begin{tabular}{|c|c|c|c|c|c|c|c|}
\hline Tratamentos & AP & $A E$ & $\mathrm{PO}$ & $\mathrm{IE}$ & $\mathrm{PE}$ & $\% T_{1}$ & $\% \mathrm{~T}_{2}$ \\
\hline Moroti (V1) & 206 & 114 & 0,55 & 0,73 & 2,86 & 62,8 & 65,6 \\
\hline Porangatu (V2) & 186 & 104 & 0,55 & 0,75 & 3,00 & 65,9 & 68,8 \\
\hline Taitinga (V3) & 206 & 113 & 0,54 & 0,88 & 3,65 & 80,2 & 83,7 \\
\hline lubatã (V4) & 191 & 97 & 0,50 & 0,90 & 3,35 & 73,6 & 76,8 \\
\hline Taiúba (V5) & 179 & 93 & 0,51 & 0,82 & 3,40 & 74,7 & 77,9 \\
\hline WP 12 (V6) & 218 & 136 & 0,62 & 0,68 & 2,98 & 65,4 & 68,3 \\
\hline Philipine DMR 2 (V7) & 188 & 103 & 0,54 & 0,78 & 2,51 & 55,1 & 57,5 \\
\hline Suwan 2 (V8) & 180 & 97 & 0,54 & 0,86 & 3,86 & 84,8 & 88,5 \\
\hline Caripeño DMR (V9) & 183 & 105 & 0,57 & 0,76 & 2,31 & 50,7 & 52,9 \\
\hline Amarillo Dentado DMR (V10) & 188 & 98 & 0,52 & 0,70 & 3,01 & 66,1 & 69,0 \\
\hline Cupurico DMR (V11) & 172 & 87 & 0,50 & 0,86 & 3,52 & 77,3 & 80,7 \\
\hline Tuxpeño Crema I (V12) & 183 & 101 & 0,55 & 0,64 & 3,00 & 65,9 & 68,8 \\
\hline Tuxpeño Amarillo (V13) & 155 & 79 & 0,50 & 0,74 & 3,29 & 72,3 & 75,4 \\
\hline $\mathrm{V} 1 \times \mathrm{V} 7$ & 179 & 97 & 0,54 & 0,75 & 3,18 & 69,8 & 72,9 \\
\hline $\mathrm{V} 1 \times \mathrm{V} 8$ & 191 & 111 & 0,58 & 0,74 & 3,40 & 74,7 & 77,9 \\
\hline $\mathrm{V} 1 \times \mathrm{V} 9$ & 191 & 107 & 0,55 & 0,72 & 3,21 & 70,5 & 73,6 \\
\hline $\mathrm{V} 1 \times \mathrm{V} 10$ & 190 & 107 & 0,56 & 0,81 & 3,07 & 67,4 & 70,4 \\
\hline V1 x V11 & 189 & 101 & 0,53 & 0,85 & 3,88 & 85,2 & 88,9 \\
\hline $\mathrm{V} 1 \times \mathrm{V} 12$ & 193 & 107 & 0,55 & 0,69 & 3,02 & 66,3 & 69,2 \\
\hline V1 $x$ V13 & 183 & 90 & 0,49 & 0,80 & 4,10 & 90,1 & 94,0 \\
\hline V2 x V7 & 196 & 104 & 0,53 & 0,85 & 3,50 & 76,9 & 80,2 \\
\hline $\mathrm{V} 2 \times \mathrm{V} 8$ & 179 & 96 & 0,53 & 0,84 & 3,47 & 76,2 & 79,5 \\
\hline V2 $\times$ V9 & 198 & 108 & 0,54 & 0,73 & 2,80 & 61,5 & 64,2 \\
\hline $\mathrm{V} 2 \times \mathrm{V} 10$ & 179 & 91 & 0,51 & 0,77 & 3,41 & 74,9 & 78,2 \\
\hline $\mathrm{V} 2 \times \mathrm{V} 11$ & 178 & 95 & 0,53 & 0,81 & 3,27 & 71,8 & 75,0 \\
\hline $\mathrm{V} 2 \times \mathrm{V} 12$ & 186 & 100 & 0,53 & 0,78 & 3,60 & 79,1 & 82,5 \\
\hline $\mathrm{V} 2 \times \mathrm{V} 13$ & 172 & 94 & 0,54 & 0,76 & 3,31 & 72,7 & 75,9 \\
\hline V3 x V7 & 193 & 100 & 0,51 & 0,90 & 3,34 & 73,4 & 76,6 \\
\hline V3 $\times$ V8 & 188 & 108 & 0,57 & 0,75 & 3,35 & 73,6 & 76,8 \\
\hline V3 x V9 & 183 & 101 & 0,55 & 0,85 & 4,07 & 89,4 & 93,3 \\
\hline $\mathrm{V} 3 \times \mathrm{V} 10$ & 183 & 107 & 0,58 & 0,72 & 3,13 & 68,7 & 71,7 \\
\hline V3 x V11 & 178 & 95 & 0,53 & 0,77 & 3,58 & 78,6 & 82,1 \\
\hline V3 x V12 & 183 & 105 & 0,57 & 0,77 & 3,32 & 72,9 & 76,1 \\
\hline $\mathrm{V} 3 \times \mathrm{V} 13$ & 181 & 95 & 0,52 & 0,82 & 4,34 & 95,3 & 99,5 \\
\hline V4 x V7 & 185 & 106 & 0,57 & 0,80 & 2,93 & 64,4 & 67,2 \\
\hline V4 x V8 & 189 & 103 & 0,54 & 0,68 & 2,85 & 62,6 & 65,3 \\
\hline V4 x V9 & 195 & 114 & 0,58 & 0,80 & 2,89 & 63,5 & 66,2 \\
\hline V4 x V10 & 183 & 106 & 0,57 & 0,77 & 3,38 & 74,2 & 77,5 \\
\hline V4 x V11 & 188 & 104 & 0,55 & 0,82 & 3,63 & 79,7 & 83,2 \\
\hline V4 x V12 & 174 & 91 & 0,52 & 0,57 & 2,32 & 50,9 & 53,2 \\
\hline V4 x V13 & 164 & 86 & 0,52 & 0,82 & 3,16 & 69,4 & 72,4 \\
\hline V5 x V7 & 195 & 104 & 0,53 & 0,86 & 3,27 & 71,8 & 75,0 \\
\hline V5 x V8 & 190 & 109 & 0,57 & 0,87 & 4,03 & 88,5 & 92,4 \\
\hline V5 x V9 & 192 & 105 & 0,54 & 0,75 & 3,65 & 80,2 & 83,7 \\
\hline V5 $x$ V10 & 171 & 86 & 0,50 & 0,81 & 3,53 & 77,5 & 80,9 \\
\hline
\end{tabular}


Tabela 1. Médias das variedades e híbridos para altura da planta (AP) e altura da espiga (AE), em cm; posição relativa da espiga (PO); índice de espigas (IE); peso de espigas (PE), em t/ha; percentagem do peso de espigas em relação a testemunha $1\left(\% \mathrm{~T}_{1}\right)$ e percentagem do peso de espigas em relação a testemunha $2\left(\% \mathrm{~T}_{2}\right)$, e coeficientes de variação experimental (CV). Experimento 1, Anhembi, SP, 1997/98. (Continuação)

\begin{tabular}{|c|c|c|c|c|c|c|c|}
\hline Tratamentos & $\overline{A P}$ & $\mathrm{AE}$ & $\mathrm{PO}$ & $\mathrm{IE}$ & $\mathrm{PE}$ & $\% T_{1}$ & $\% \mathrm{~T}_{2}$ \\
\hline $\mathrm{V} 5 \times \mathrm{V} 11$ & 184 & 92 & 0,50 & 0,84 & 4,02 & 88,3 & 92,2 \\
\hline $\mathrm{V} 5 \times \mathrm{V} 12$ & 186 & 105 & 0,55 & 0,67 & 2,86 & 62,8 & 65,6 \\
\hline$V 5 \times V 13$ & 175 & 90 & 0,51 & 0,83 & 3,87 & 85,0 & 88,7 \\
\hline V6 x V7 & 201 & 116 & 0,58 & 0,82 & 3,32 & 72,9 & 76,1 \\
\hline $\mathrm{V} 6 \times \mathrm{V} 8$ & 191 & 114 & 0,59 & 0,81 & 3,68 & 80,8 & 84,4 \\
\hline $\mathrm{V} 6 \times \mathrm{V} 9$ & 203 & 126 & 0,62 & 0,74 & 3,53 & 77,5 & 80,9 \\
\hline$V 6 \times V 10$ & 196 & 116 & 0,59 & 0,84 & 3,86 & 84,8 & 88,5 \\
\hline $\mathrm{V} 6 \times \mathrm{V} 11$ & 193 & 112 & 0,57 & 0,83 & 3,99 & 87,6 & 91,5 \\
\hline $\mathrm{V} 6 \times \mathrm{V} 12$ & 189 & 108 & 0,57 & 0,78 & 3,40 & 74,7 & 77,9 \\
\hline$V 6 \times V 13$ & 190 & 106 & 0,55 & 0,75 & 3,47 & 76,2 & 79,5 \\
\hline Média geral & 186 & 102 & 0.54 & 0,78 & 3,36 & 73.8 & 77.0 \\
\hline Média $T_{1}$ & 159 & 84 & 0,53 & 0,85 & 4,55 & -- & $-\ldots$ \\
\hline Média $T_{2}$ & 181 & 108 & 0,59 & 0,74 & 4,36 & -- & -. \\
\hline CV (\%) & 7,2 & 11.7 & 7,5 & 12,9 & 19,2 & -. & -- \\
\hline
\end{tabular}

Grupo [1]: V1, V2, V3, V4, V5, V6; Grupo [2]: V7, V8, V9, V10, V11, V12, V13.

$T_{1}: A G 6601 ; T_{2}: A G 5011$. 
Tabela 2. Resumo das análises de variância de cruzamento dialélico parcial para altura da planta (AP) e altura da espiga (AE), em cm; e peso de espigas (PE), em tha. Experimento 1 . Anhembi, SP, 1997/98.

\begin{tabular}{lcccc}
\hline Fontes de variação & GL & \multicolumn{3}{c}{ Quadrados médios } \\
\cline { 4 - 5 } & & $\mathrm{AP}$ & $\mathrm{AE}$ & $\mathrm{PE}\left(10^{\mathrm{s}}\right)$ \\
\hline Tratamentos & 54 & $110,729^{\star \star}$ & $102,235^{\star \star}$ & $188,803^{\star \star}$ \\
Variedades [1] & 5 & $294,306^{\star \star}$ & $439,333^{\star \star}$ & $284,340^{\star}$ \\
Variedades [2] & 6 & $265,533^{\star \star}$ & $242,823^{\star \star}$ & $471,111^{\star \star}$ \\
Grupos & 1 & $1176,450^{\star \star}$ & $618,917^{\star \star}$ & $92,990^{\text {ns }}$ \\
Heteroses & 42 & $41,385^{\text {ns }}$ & $29,719^{\text {ns }}$ & $139,382^{\text {ns }}$ \\
Heterose média & 1 & $28,240^{\text {ns }}$ & $0,404^{\text {ns }}$ & $827,020^{\star \star}$ \\
Heterose variedades [1] & 5 & $62,003^{\text {ns }}$ & $31,633^{\text {ns }}$ & $176,466^{\text {ns }}$ \\
Heterose variedades [2] & 6 & $42,276^{\text {ns }}$ & $14,549^{\text {ns }}$ & $146,401^{n s}$ \\
Heterose especifica & 30 & $38,209^{\text {ns }}$ & $33,411^{\text {ns }}$ & $108,876^{\text {ns }}$ \\
\hline CGC [1] & 5 & $140,042^{\star \star}$ & $232,266^{\star \star}$ & $367,060^{\star \star}$ \\
CGC [2] & 6 & $171,523^{\star \star}$ & $169,134^{\star \star}$ & $321,733^{\star \star}$ \\
\hline Residuo & 162 & 46,303 & 36,970 & 104,297 \\
\hline
\end{tabular}

Quadrados médios em nivel de média de repetições.

$\left(10^{3}\right)$ : Quadrados médios multiplicados por $10^{3}$.

ns, ${ }^{\star} e^{* *}$ : não significativos, significativos ao nivel de $5 \%$ e $1 \%$ de probabilidade, respectivamente. 
Tabela 3. Estimativas dos efeitos de variedades $\left(v_{i}\right.$ e $\left.v_{j}\right)$, heterose de variedades $\left(h_{i}\right.$ e $\left.h_{j}\right)$ e capacidade geral de combinação $\left(g_{i}\right.$ e $\left.g_{j}\right)$, para altura da planta (AP) e altura da espiga $(A E)$, em cm; e peso de espigas (PE), em t/ha. Experimento 1. Anhembi, SP, $1997 / 98$.

\begin{tabular}{|c|c|c|c|c|c|c|c|c|c|}
\hline \multirow[b]{2}{*}{ Grupo [1] } & \multicolumn{3}{|c|}{ AP } & \multicolumn{3}{|c|}{$\mathrm{AE}$} & \multicolumn{3}{|c|}{$P E$} \\
\hline & $v_{i}$ & $\hat{h}_{i}$ & $\hat{g}_{i}$ & $\hat{v}_{i}$ & $\hat{h}_{i}$ & $\hat{g}_{i}$ & $\hat{v}_{i}$ & $\hat{h}_{i}$ & $\hat{g}_{i}$ \\
\hline $\begin{array}{l}\text { Moroti } \\
\text { Porangatu } \\
\text { Taitinga } \\
\text { lubatã } \\
\text { Taiúba } \\
\text { WP } 12\end{array}$ & $\begin{array}{c}8,33 \\
-11,66 \\
8,33 \\
-6,66 \\
-18,66 \\
20,33 \\
\end{array}$ & $\begin{array}{c}-2,52 \\
3,47 \\
-6,38 \\
-0,45 \\
7,69 \\
-1,80 \\
\end{array}$ & $\begin{array}{c}1,64 \\
-2,35 \\
-2,21 \\
-3,78 \\
-1,64 \\
8,35 \\
\end{array}$ & $\begin{array}{c}4,50 \\
-5,50 \\
3,50 \\
-12,50 \\
-16,50 \\
26,50 \\
\end{array}$ & $\begin{array}{c}-2,20 \\
-1,77 \\
-2,98 \\
4,86 \\
4,15 \\
-2,05 \\
\end{array}$ & $\begin{array}{l}0,04 \\
-4,52 \\
-1,23 \\
-1,38 \\
-4,09 \\
11,19 \\
\end{array}$ & $\begin{array}{c}-0,346 \\
-0,206 \\
0,443 \\
0,143 \\
0,193 \\
-0,226 \\
\end{array}$ & $\begin{array}{c}0,153 \\
0,012 \\
-0,060 \\
-0,477 \\
0,079 \\
0,292 \\
\end{array}$ & $\begin{array}{c}-0,019 \\
-0,091 \\
0,161 \\
-0,405 \\
0,176 \\
0,178 \\
\end{array}$ \\
\hline Grupo [2] & $v_{j}$ & $h_{j}$ & $\hat{g}_{j}$ & $\hat{v}_{j}$ & $\hat{h}_{j}$ & $\hat{g}_{j}$ & $\hat{v}_{j}$ & $\hat{h}_{j}$ & $\hat{g}_{j}$ \\
\hline $\begin{array}{l}\text { Philipine DMR } 2 \\
\text { Suwan } 2 \\
\text { Caripeño DMR } \\
\text { Amarillo Dent. DMR } \\
\text { Cupurico DMR } \\
\text { Tuxpeño Crema I } \\
\text { Tuxpeño Amarillo }\end{array}$ & $\begin{array}{c}9,57 \\
1,57 \\
4,57 \\
9,57 \\
-6,42 \\
4,57 \\
-23,42\end{array}$ & $\begin{array}{c}0,35 \\
0,85 \\
5,02 \\
-7,47 \\
1,85 \\
-3,47 \\
2,85\end{array}$ & $\begin{array}{r}5,14 \\
1,64 \\
7,30 \\
-2,69 \\
-1,35 \\
-1,19 \\
-8,85\end{array}$ & $\begin{array}{c}7,28 \\
1,28 \\
9,28 \\
2,28 \\
-8,71 \\
5,28 \\
-16,71\end{array}$ & $\begin{array}{c}-1,95 \\
3,38 \\
2,71 \\
-1,78 \\
1,38 \\
-2,78 \\
-0,95\end{array}$ & $\begin{array}{r}1,69 \\
4,02 \\
7,35 \\
-0,64 \\
-2,97 \\
-0,14 \\
-9,30\end{array}$ & $\begin{array}{c}-0,561 \\
0,788 \\
-0,761 \\
-0,061 \\
0,448 \\
-0,071 \\
0,218\end{array}$ & $\begin{array}{c}0,109 \\
-0,359 \\
0,310 \\
-0,001 \\
0,075 \\
-0,306 \\
0,170\end{array}$ & $\begin{array}{r}-0,171 \\
0,035 \\
-0,070 \\
-0,031 \\
0,300 \\
-0,341 \\
0,280\end{array}$ \\
\hline$\mu$ & & 188,04 & & & 102,60 & & & 3,13 & \\
\hline$\hat{h}$ & & $-1,69$ & & & 0,20 & & & 0,28 & \\
\hline$d$ & & 9,61 & & & 6,89 & & & 0,06 & \\
\hline
\end{tabular}


Tabela 4. Estimativas de heterose (h) e percentual de heterose (\%h) em relação a média das variedades progenitoras; e estimativas de heterose $\left(h_{s}\right)$ e percentual de heterose $\left(\% h_{s}\right)$ em relação a variedade progenitora de maior média, para o peso de espigas (PE) eln tha. Experimento 1. Anhembi, SP, 1997/98.

\begin{tabular}{|c|c|c|c|c|}
\hline Hibridos & $\mathrm{h}$ & $\% \mathrm{~h}$ & $h_{\mathrm{s}}$ & $\% h_{s}$ \\
\hline V1 $\times$ V7 & 0.50 & 18,4 & 0.32 & 11,1 \\
\hline $\mathrm{V} 1 \times \mathrm{V} 8$ & 0.04 & 1,1 & $=0.46$ & $=11,9$ \\
\hline$\vee 1 \times \vee 9$ & 0.63 & 24,8 & 0.35 & 12,2 \\
\hline $\mathrm{V} 1 \times \mathrm{V} 10$ & 0.14 & 4,6 & 0.06 & 1,9 \\
\hline $\mathrm{V} 1 \times \mathrm{V} 11$ & 0.69 & 21,6 & 0.36 & 10,2 \\
\hline $\mathrm{V} 1 \times \mathrm{V} 12$ & 0.09 & 3,0 & 0.02 & 0,6 \\
\hline $\mathrm{V} 1 \times \mathrm{V} 13$ & 1.03 & 33,3 & 0.81 & 24,6 \\
\hline V2 x V7 & 0.75 & 27,0 & 0.50 & 16,6 \\
\hline V2 x V8 & 0.04 & 1,1 & -0.39 & $-10,1$ \\
\hline V2 $\times$ V9 & 0.15 & 5,4 & -0.20 & $-6,6$ \\
\hline $\mathrm{V} 2 \times \mathrm{V} 10$ & 0.41 & 13,4 & 0.40 & 13,2 \\
\hline $\mathrm{V} 2 \times \mathrm{V} 11$ & 0.01 & 0,3 & -0.25 & $-7,1$ \\
\hline $\mathrm{V} 2 \times \mathrm{V} 12$ & 0.60 & 20,0 & 0.60 & 20,0 \\
\hline $\mathrm{V} 2 \times \mathrm{V} 13$ & 0.17 & 5,2 & 0.02 & 0,6 \\
\hline V3 x V7 & 0.26 & 8,4 & -0.31 & $-8,4$ \\
\hline V3 $x$ V8 & -0.41 & $-10,7$ & -0.51 & $-13,2$ \\
\hline V3 x V9 & 1.09 & 36,5 & 0.42 & 11,5 \\
\hline $\mathrm{V} 3 \times \mathrm{V} 10$ & -0.20 & $-6,0$ & -0.52 & $-14,2$ \\
\hline$V 3 \times V 11$ & 0.00 & $-0,1$ & -0.07 & $-1,9$ \\
\hline $\mathrm{V} 3 \times \mathrm{V} 12$ & -0.01 & $-0,1$ & -0.33 & $-9,0$ \\
\hline$\vee 3 \times \vee 13$ & 0.87 & 25,0 & 0.69 & 18,9 \\
\hline$\vee 4 \times \vee 7$ & 0.00 & 0,0 & -0.42 & $-12,5$ \\
\hline V4 x V8 & -0.76 & $-20,9$ & -1.01 & $-26,1$ \\
\hline V4 x V9 & 0.06 & 2,1 & -0.46 & $-13,7$ \\
\hline $\mathrm{V} 4 \times \mathrm{V} 10$ & 0.20 & 6,2 & 0.03 & 0,9 \\
\hline $\mathrm{V} 4 \times \mathrm{V} 11$ & 0.20 & 5,6 & 0.11 & 3,1 \\
\hline $\mathrm{V} 4 \times \mathrm{V} 12$ & -0.86 & $-26,9$ & -1.03 & $-30,7$ \\
\hline$\vee 4 \times \vee 13$ & -0.16 & $-4,8$ & -0.19 & $-5,6$ \\
\hline V5 x V7 & 0.32 & 10,6 & -0.13 & $-3,8$ \\
\hline V5 $\times$ V8 & 0.40 & 11,0 & 0.17 & 4,4 \\
\hline V5 x V9 & 0.80 & 27,8 & 0.25 & 7,3 \\
\hline $\mathrm{V} 5 \times \mathrm{V} 10$ & 0.33 & 10,1 & 0.13 & 3,8 \\
\hline $\mathrm{V} 5 \times \mathrm{V} 11$ & 0.56 & 16,1 & 0.50 & 14,2 \\
\hline $\mathrm{V} 5 \times \mathrm{V} 12$ & -0.34 & $-10,6$ & -0.54 & $-15,8$ \\
\hline $\mathrm{V} 5 \times \mathrm{V} 13$ & 0.53 & 15,7 & 0.47 & 13,8 \\
\hline V6 x V7 & 0.58 & 20,9 & 0.34 & 11,4 \\
\hline V6 $\times$ V8 & 0.26 & 7,6 & -0.18 & $-4,6$ \\
\hline V6 x V9 & 0.89 & 33,4 & 0.55 & 18,4 \\
\hline $\mathrm{V} 6 \times \mathrm{V} 10$ & 0.87 & 28,8 & 0.85 & 28,2 \\
\hline $\mathrm{V} 6 \times \mathrm{V} 11$ & 0.74 & 22,7 & 0.47 & 13,3 \\
\hline $\mathrm{V} 6 \times \mathrm{V} 12$ & 0.41 & 13,7 & 0.40 & 13,3 \\
\hline $\mathrm{V} 6 \times \mathrm{V} 13$ & 0.34 & 10,6 & 0.18 & 5,4 \\
\hline
\end{tabular}

Grupo [1]: Moroti (V1), Porangatu (V2), Taitinga (V3), lubatã (V4), Taiúba (V5), WP 12 (V6).

Grupo [2]: Philipine DMR 2 (V7), Suwan 2 (V8), Caripeño DMR (V9), Amarillo Dentado DMR (V10), Cupurico DMR (V11), Tuxpeño Crema I (V12), Tuxpeño Amarillo (V13). 
Tabela 5. Médias das variedades e híbri dos para altur a da planta (AP) e altura da espi ga (AE), em $\mathrm{cm}$; posição relativa da espi ga(PO); índice de espigas (IE); peso de espigas (PE), em t/ha; percentagem do peso de espi gas em relação a testemunha $1\left(\% T_{1}\right)$ e percentagem do peso de espi gasem relação a testemunha $2\left(\% \mathrm{~T}_{2}\right)$, e coeficientes de variação experi mental(CV). Experimento 2, Anhembi, SP, 1997/98.

\begin{tabular}{|c|c|c|c|c|c|c|c|}
\hline Tratamentos & AP & $A E$ & $\mathrm{PO}$ & IE & $P E$ & $\% T_{1}$ & $\% \mathrm{~T}_{2}$ \\
\hline BR 105 (V1) & 182 & 104 & 0,57 & 0,72 & 3,48 & 71,7 & 71,4 \\
\hline CMS 58ND (V2) & 199 & 111 & 0,55 & 0,62 & 3,68 & 75,8 & 75,5 \\
\hline CMS 59 (V3) & 165 & 98 & 0,60 & 0,63 & 2,67 & 55,0 & 54,8 \\
\hline WP 12 (V4) & 214 & 128 & 0,60 & 0,53 & 2,64 & 54,4 & 54,2 \\
\hline Amarill o Dentado DMR (V5) & 174 & 98 & 0,56 & 0,71 & 3,53 & 72,7 & 72,4 \\
\hline ESALQ PB2 $\times$ ESALQPB3 (V6) & 179 & 99 & 0,55 & 0,63 & 3,21 & 66,1 & 65,9 \\
\hline CMS 57NF (V7) & 183 & 96 & 0,52 & 0,69 & 3,74 & 77,1 & 76,8 \\
\hline IAPAR 51 (V8) & 183 & 94 & 0,51 & 0,63 & 3,19 & 65,7 & 65,5 \\
\hline PMI 8701 (V9) & 184 & 101 & 0,55 & 0,91 & 4,52 & 93,2 & 92,8 \\
\hline PMI 9401 (V10) & 202 & 124 & 0,62 & 0,55 & 3,71 & 76,4 & 76,1 \\
\hline V1 $\times$ V2 & 193 & 102 & 0,53 & 0,76 & 4,47 & 92,1 & 91,7 \\
\hline $\mathrm{V} 1 \times \mathrm{V} 3$ & 174 & 101 & 0,58 & 0,85 & 4,36 & 89,9 & 89,5 \\
\hline $\mathrm{V} 1 \times \mathrm{V} 4$ & 201 & 117 & 0,58 & 0,68 & 3,83 & 78,9 & 78,6 \\
\hline $\mathrm{V} 1 \times \mathrm{V} 5$ & 186 & 97 & 0,52 & 0,81 & 3,76 & 77,5 & 77,2 \\
\hline $\mathrm{V} 1 \times \mathrm{V} 6$ & 195 & 122 & 0,63 & 0,80 & 4,09 & 84,3 & 83,9 \\
\hline $\mathrm{V} 1 \times \mathrm{V} 7$ & 179 & 88 & 0,49 & 0,80 & 4,03 & 83,0 & 82,7 \\
\hline $\mathrm{V} 1 \times \mathrm{V} 8$ & 196 & 111 & 0,56 & 0,78 & 4,30 & 88,6 & 88,3 \\
\hline V1 $\times$ V9 & 186 & 96 & 0,52 & 0,80 & 4,36 & 89,9 & 89,5 \\
\hline $\mathrm{V} 1 \times \mathrm{V} 10$ & 194 & 108 & 0,56 & 0,82 & 4,86 & 100,2 & 99,7 \\
\hline V2 x V3 & 183 & 100 & 0,55 & 0,76 & 4,06 & 83,6 & 83,3 \\
\hline$V 2 \times V 4$ & 199 & 111 & 0,56 & 0,58 & 3,77 & 77,7 & 77,4 \\
\hline $\mathrm{V} 2 \times \mathrm{V} 5$ & 186 & 99 & 0,53 & 0,78 & 3,89 & 80,2 & 79,8 \\
\hline $\mathrm{V} 2 \times \mathrm{V} 6$ & 196 & 111 & 0,56 & 0,81 & 4,03 & 83,0 & 82,7 \\
\hline $\mathrm{V} 2 \times \mathrm{V} 7$ & 180 & 93 & 0,51 & 0,73 & 3,92 & 80,8 & 80,4 \\
\hline$V 2 \times V 8$ & 191 & 103 & 0,54 & 0,68 & 4,19 & 86,3 & 86,0 \\
\hline $\mathrm{V} 2 \times \mathrm{V} 9$ & 177 & 88 & 0,50 & 0,67 & 4,10 & 84,5 & 84,1 \\
\hline $\mathrm{V} 2 \times \mathrm{V} 10$ & 200 & 108 & 0,54 & 0,72 & 4,04 & 83,3 & 82,9 \\
\hline V3 x V4 & 194 & 118 & 0,61 & 0,72 & 4,65 & 95,8 & 95,4 \\
\hline$\vee 3 \times \vee 5$ & 173 & 96 & 0,56 & 0,80 & 3,59 & 74,0 & 73,7 \\
\hline$V 3 \times V 6$ & 184 & 108 & 0,58 & 0,89 & 4,69 & 96,7 & 96,3 \\
\hline$\vee 3 \times \vee 7$ & 176 & 99 & 0,56 & 0,87 & 4,13 & 85,1 & 84,8 \\
\hline$V 3 \times V 8$ & 180 & 93 & 0,51 & 0,78 & 4,24 & 87,4 & 87,0 \\
\hline $\mathrm{V} 3 \times \mathrm{V} 9$ & 188 & 117 & 0,62 & 0,77 & 3,81 & 78,5 & 78,2 \\
\hline $\mathrm{V} 3 \times \mathrm{V} 10$ & 192 & 118 & 0,62 & 0,68 & 4,41 & 90,9 & 90,5 \\
\hline V4 x V5 & 176 & 96 & 0,55 & 0,72 & 3,15 & 64,9 & 64,6 \\
\hline$\vee 4 \times \vee 6$ & 198 & 116 & 0,58 & 0,61 & 3,48 & 71,7 & 71,4 \\
\hline$\vee 4 \times \vee 7$ & 204 & 116 & 0,56 & 0,67 & 3,56 & 73,4 & 73,1 \\
\hline$\vee 4 \times \vee 8$ & 204 & 114 & 0,56 & 0,52 & 3,51 & 72,3 & 72,0 \\
\hline $\mathrm{V} 4 \times \mathrm{V} 9$ & 201 & 113 & 0,56 & 0,78 & 3,93 & 81,0 & 80,7 \\
\hline $\mathrm{V} 4 \times \mathrm{V} 10$ & 203 & 126 & 0,62 & 0,57 & 3,74 & 77,1 & 76,8 \\
\hline V5 x V6 & 194 & 117 & 0,60 & 0,85 & 4,56 & 94,0 & 93,6 \\
\hline$\vee 5 \times \vee 7$ & 173 & 95 & 0,56 & 0,87 & 4,17 & 85,9 & 85,6 \\
\hline V5 $\times$ V8 & 188 & 109 & 0,58 & 0,87 & 4,67 & 96,2 & 95,8 \\
\hline V5 $\times$ V9 & 186 & 103 & 0,56 & 0,86 & 4,46 & 91,9 & 91,5 \\
\hline $\mathrm{V} 5 \times \mathrm{V} 10$ & 194 & 121 & 0,62 & 0,76 & 4,25 & 87,6 & 87,2 \\
\hline
\end{tabular}


Tabela 5. Médias das variedades e hibridos para altura da planta (AP) e altura da espiga (AE), em cm; posição relativa da espiga (PO); índice de espigas (IE); peso de espigas (PE), em t/ha; percentagem do peso de espigas em relação a testemunha $1\left(\% T_{1}\right)$ e percentagem do peso de espigas em relação a testemunha $2\left(\% \mathrm{~T}_{2}\right)$, e coeficientes de variação experimental (CV). Experimento 2, Anhembi, SP, 1997/98. (Continuação)

\begin{tabular}{|c|c|c|c|c|c|c|c|}
\hline Tratamentos & AP & $\mathrm{AE}$ & $\mathrm{PO}$ & $\mathrm{IE}$ & $\mathrm{PE}$ & $\% \mathrm{~T}_{1}$ & $\% \mathrm{~T}_{2}$ \\
\hline $\mathrm{V} 6 \times \mathrm{V} 7$ & 183 & 100 & 0,55 & 0,77 & 4,12 & 84,9 & 84,6 \\
\hline $\mathrm{V} 6 \times \mathrm{V} 8$ & 191 & 106 & 0,56 & 0,75 & 3,98 & 82,0 & 81,7 \\
\hline $\mathrm{V} 6 \times \mathrm{V} 9$ & 186 & 96 & 0,52 & 0,75 & 4,35 & 89,6 & 89,3 \\
\hline$V 6 \times V 10$ & 182 & 103 & 0,56 & 0,71 & 3,78 & 77,9 & 77,6 \\
\hline V7 x V8 & 179 & 103 & 0,57 & 0,83 & 4,73 & 97,5 & 97,1 \\
\hline V7 $\times$ V9 & 182 & 98 & 0,53 & 0,97 & 5,11 & 105,3 & 104,9 \\
\hline $\mathrm{V} 7 \times \mathrm{V} 10$ & 186 & 106 & 0,57 & 0,69 & 3,98 & 82,0 & 81,7 \\
\hline V8 x V9 & 189 & 99 & 0,52 & 0,69 & 3,91 & 80,6 & 80,2 \\
\hline $\mathrm{V} 8 \times \mathrm{V} 10$ & 188 & 99 & 0.52 & 0,71 & 4,16 & 85,7 & 85,4 \\
\hline$\vee 9 \times \vee 10$ & 189 & 106 & 0,56 & 0,76 & 4,26 & 87,8 & 87,4 \\
\hline Média geral & 188 & 105 & 0.56 & 0,74 & 3,99 & 82,4 & 82,0 \\
\hline Média $T_{1}$ & 164 & 84 & 0,51 & 0,87 & 4,85 & -- & -- \\
\hline Média $T_{2}$ & 185 & 108 & 0.58 & 0,77 & 4,87 & -- & -- \\
\hline CV (\%) & 5,4 & 10,7 & 7.9 & 16,9 & 16,2 & -- & -- \\
\hline
\end{tabular}

$T_{1}: A G 6601 ; T_{2}: A G 5011$. 
Tabela 6. Resumo das análises de variância de cruzamento dialélico para altura da planta (AP) e altura da espiga $(A E)$, em $\mathrm{cm}$; e peso de espigas (PE), em tha. Experimento 2, Anhembi, SP, $1997 / 98$.

\begin{tabular}{lcccc}
\hline Fontes de variação & $G L$ & \multicolumn{3}{c}{ Quadrados médios } \\
\cline { 3 - 5 } & & AP & $A E$ & $P E\left(10^{3}\right)$ \\
\hline Tratamentos & 54 & $96,846^{\star \star}$ & $96,361^{\star \star}$ & $248,241^{\star \star}$ \\
Variedades & 9 & $386,292^{\star \star}$ & $296,125^{\star \star}$ & $383,736^{\star \star}$ \\
Heteroses & 45 & $38,957^{\star}$ & $56,408^{\star \star}$ & $221,142^{\star \star}$ \\
Heterose média & 1 & $30,231^{\text {ns }}$ & $0,227^{\text {ns }}$ & $3826,670^{\star \star}$ \\
Heterose variedades & 9 & $42,674^{\text {ns }}$ & $45,824^{\text {ns }}$ & $154,916^{\text {ns }}$ \\
Heterose específica & 35 & $38,250^{\text {ns }}$ & $60,735^{\star \star}$ & $135,156^{\text {ns }}$ \\
\hline CGC & 9 & $220,244^{\star \star}$ & $199,938^{\star \star}$ & $233,674^{\star}$ \\
\hline Residuo & 162 & 25,819 & 29,269 & 105,131
\end{tabular}

Quadrados médios em nível de média de repetições.

$\left(10^{3}\right)$ : Quadrados médios multiplicados por $10^{3}$.

ns, * $e^{\star \star}$ : não significativos, significativos ao nivel de $5 \%$ e $1 \%$ de probabilidade, respectivamente. 
Tabela 7. Estimativas dos efeitos de variedades $\left(v_{i}\right)$, heterose de variedades $\left(h_{i}\right)$ e capacidade geral de combinação $\left(g_{i}\right)$, para attura da planta (AP) e altura da espiga (AE), em cm; e peso de espigas (PE), em t/ha. Experimento 2, Anhembi, SP, 1997/98.

\begin{tabular}{|c|c|c|c|c|c|c|c|c|c|}
\hline Variedades & & AP & & & $A E$ & & & $P E$ & \\
\hline & $\hat{v}_{i}$ & $h_{i}$ & $g_{i}$ & $v_{?}$ & $h_{i}$ & $g_{i}$ & $v_{i}$ & $h_{1}$ & $\hat{g}_{i}$ \\
\hline BR 105 & $-4,50$ & 3,27 & 1,02 & $-1,30$ & $-0,25$ & $-0,90$ & 0,043 & 0,100 & 0,121 \\
\hline CMS 58ND & 12,50 & $-5,10$ & 1,15 & 5,70 & $-7,12$ & $-4,27$ & 0,243 & $-0,198$ & $-0,077$ \\
\hline CMS 59 - S.E & $-21,50$ & 4,27 & $-6,47$ & $-7,30$ & 3,75 & 0,10 & $-0,767$ & 0,490 & 0,106 \\
\hline WP 12 & 27,50 & $-3,22$ & 10,52 & 22,70 & $-1,62$ & 9,72 & $-0,797$ & $-0,035$ & $-0,433$ \\
\hline Amarillo Dentado DMR & $-12,50$ & 1,27 & $-4,97$ & $-7,30$ & 1,62 & $-2,02$ & 0,093 & $-0,120$ & $-0,073$ \\
\hline ESALQ PB2 $\times$ ESALQPB3 & $-7,50$ & 5,40 & 1,65 & $-6,30$ & 6,87 & 3,72 & $-0,227$ & 0,112 & $-0,001$ \\
\hline CMS 57NF & $-3,50$ & $-4,97$ & $-6,72$ & $-9,30$ & $-1,75$ & $-6,40$ & 0,303 & $-0,068$ & 0,082 \\
\hline IAPAR 51 & $-3,50$ & 3,02 & 1,27 & $-11,30$ & 4,12 & $-1,52$ & $-0,247$ & 0,198 & 0,075 \\
\hline PMI 8701 & $-2,50$ & $-0,22$ & $-1,47$ & $-4,30$ & $-2,00$ & $-4,15$ & 1,083 & $-0,391$ & 0,150 \\
\hline PMI 9401 & 15,50 & $-3,72$ & 4,02 & 18,70 & $-3,62$ & 5,72 & 0,273 & $-0,087$ & 0,049 \\
\hline$\mu$ & & 186,50 & & & 105,30 & & & 3,437 & \\
\hline$\frac{1}{h}$ & & 1,92 & & & 0,16 & & & 0,683 & \\
\hline
\end{tabular}


Tabela 8. Estimativas de heterose (h) e percentual de heterose (\%h) em relação a média das variedades progenitoras; e estimativas de heterose $\left(h_{s}\right)$ e percentual de heterose $\left(\% h_{s}\right)$ em relação a variedade progenitora de maior média, para o peso de espigas (PE) em t/ha. Experimento 2, Anhembi, SP, 1997/98.

\begin{tabular}{|c|c|c|c|c|}
\hline Hibridos & $\mathrm{h}$ & $\% \mathrm{~h}$ & $h_{s}$ & $\% h_{s}$ \\
\hline $\mathrm{V} 1 \times \mathrm{V} 2$ & 0.89 & 24.8 & 0.79 & 21.4 \\
\hline $\mathrm{V} 1 \times \mathrm{V} 3$ & 1.29 & 41.7 & 0.88 & 25.2 \\
\hline $\mathrm{V} 1 \times \mathrm{V} 4$ & 0.77 & 25.1 & 0.35 & 10.0 \\
\hline $\mathrm{V} 1 \times \mathrm{V} 5$ & 0.26 & 7.2 & 0.23 & 6.5 \\
\hline $\mathrm{V} 1 \times \mathrm{V} 6$ & 0.75 & 22.2 & 0.61 & 17.5 \\
\hline $\mathrm{V} 1 \times \mathrm{V} 7$ & 0.42 & 11.6 & 0.29 & 7.7 \\
\hline $\mathrm{V} 1 \times \mathrm{V} 8$ & 0.97 & 28.9 & 0.82 & 23.5 \\
\hline V1 x V9 & 0.36 & 9.0 & -0.16 & -3.5 \\
\hline $\mathrm{V} 1 \times \mathrm{V} 10$ & 1.27 & 35.1 & 1.15 & 31.0 \\
\hline V2 x V3 & 0.88 & 27.8 & 0.38 & 10.2 \\
\hline $\mathrm{V} 2 \times \mathrm{V} 4$ & 0.61 & 19.3 & 0.09 & 2.4 \\
\hline$\vee 2 \times \vee 5$ & 0.29 & 7.9 & 0.21 & 5.7 \\
\hline $\mathrm{V} 2 \times \mathrm{V} 6$ & 0.59 & 16.9 & 0.35 & 9.5 \\
\hline$\vee 2 \times \vee 7$ & 0.21 & 5.6 & 0.18 & 4.8 \\
\hline V2 $\times$ V8 & 0.76 & 21.9 & 0.51 & 13.8 \\
\hline $\mathrm{V} 2 \times \mathrm{V} 9$ & 0.00 & 0.0 & -0.42 & -9.2 \\
\hline $\mathrm{V} 2 \times \mathrm{V} 10$ & 0.35 & 9.3 & 0.33 & 8.8 \\
\hline V3 x V4 & 2.00 & 75.1 & 1.98 & 74.1 \\
\hline$\vee 3 \times \vee 5$ & 0.49 & 15.8 & 0.06 & 1.7 \\
\hline$V 3 \times V 6$ & 1.75 & 59.5 & 1.48 & 46.1 \\
\hline $\mathrm{V} 3 \times \mathrm{V} 7$ & 0.93 & 28.8 & 0.39 & 10.4 \\
\hline V3 $x$ V8 & 1.31 & 44.7 & 1.05 & 32.9 \\
\hline $\mathrm{V} 3 \times \mathrm{V} 9$ & 0.22 & 5.9 & -0.71 & -15.7 \\
\hline$\vee 3 \times \vee 10$ & 1.22 & 38.2 & 0.70 & 18.8 \\
\hline V4 x V5 & 0.06 & 2.1 & -0.38 & -10.7 \\
\hline$V 4 \times V 6$ & 0.56 & 18.9 & 0.27 & 8.4 \\
\hline$\vee 4 \times \vee 7$ & 0.37 & 11.6 & -0.18 & -4.8 \\
\hline$\vee 4 \times \vee 8$ & 0.60 & 20.4 & 0.32 & 10.0 \\
\hline$\vee 4 \times \vee 9$ & 0.35 & 9.7 & -0.59 & -13.0 \\
\hline $\mathrm{V} 4 \times \mathrm{V} 10$ & 0.57 & 17.8 & 0.03 & 0.8 \\
\hline V5 x V6 & 1.19 & 35.3 & 1.03 & 29.1 \\
\hline$\vee 5 \times \vee 7$ & 0.54 & 14.7 & 0.43 & 11.5 \\
\hline V5 $\times$ V8 & 1.31 & 38.9 & 1.14 & 32.2 \\
\hline V5 $\times$ V9 & 0.44 & 10.8 & -0.06 & -1.3 \\
\hline $\mathrm{V} 5 \times \mathrm{V} 10$ & 0.63 & 17.4 & 0.54 & 14.5 \\
\hline V6 x V7 & 0.65 & 18.5 & 0.38 & 10.1 \\
\hline V6 $\times$ V8 & 0.78 & 24.3 & 0.77 & 23.9 \\
\hline $\mathrm{V} 6 \times \mathrm{V} 9$ & 0.49 & 12.5 & -0.17 & -3.7 \\
\hline $\mathrm{V} 6 \times \mathrm{V} 10$ & 0.32 & 9.2 & 0.07 & 1.8 \\
\hline V7 x V8 & 1.27 & 36.5 & 0.99 & 26.4 \\
\hline$\vee 7 \times \vee 9$ & 0.98 & 23.7 & 0.59 & 13.0 \\
\hline $\mathrm{V} 7 \times \mathrm{V} 10$ & 0.26 & 6.8 & 0.24 & 6.4 \\
\hline V8 x V9 & 0.06 & 1.4 & -0.61 & -13.5 \\
\hline $\mathrm{V} 8 \times \mathrm{V} 10$ & 0.71 & 20.5 & 0.45 & 12.1 \\
\hline$\vee 9 \times \vee 10$ & 0.15 & 3.5 & -0.26 & -5.7 \\
\hline
\end{tabular}


Tabela 9. Médias das variedades e "topcrosses" intragrupo para altura da planta (AP) e altura da espiga (AE), em cm; posição relativa da espiga (PO); índice de espigas (IE); peso de espigas (PE), em t/ha; percentagem do peso de espigas em relação a testemunha 1 $\left(\% T_{1}\right)$ e percentagem do peso de espigas em relação a testemunha $2\left(\% T_{2}\right)$, e coeficientes de variação experimental (CV). Experimento 3, Anhembi, SP, 1997/98.

\begin{tabular}{|c|c|c|c|c|c|c|c|}
\hline Tratamentos & AP & $A E$ & PO & $\mathrm{IE}$ & $P E$ & $\% \mathrm{~T}_{1}$ & $\% \mathrm{~T}_{2}$ \\
\hline CMS 4N (V1) & 183 & 108 & 0,59 & 0,76 & 3,78 & 79,5 & 72,9 \\
\hline CMS 4C (V2) & 168 & 99 & 0,59 & 0,64 & 3,05 & 64,1 & 58,7 \\
\hline CMS $14 \mathrm{C}$ (V3) & 189 & 109 & 0,57 & 0,75 & 3,41 & 71,8 & 65,8 \\
\hline CMS 28 (V4) & 165 & 86 & 0,52 & 0,86 & 3,96 & 83,3 & 76,4 \\
\hline BR 106 (V5) & 187 & 111 & 0,60 & 0,84 & 3,91 & 82,2 & 75,4 \\
\hline BR 111 (V6) & 184 & 107 & 0,58 & 0,85 & 3,55 & 74,7 & 68,5 \\
\hline CMS 53 (V7) & 168 & 94 & 0,56 & 0,77 & 3,56 & 74,9 & 68,6 \\
\hline CMS 54 (V8) & 185 & 105 & 0,57 & 0,90 & 3,70 & 77,8 & 71,4 \\
\hline IAPAR 50 (V9) & 200 & 128 & 0,64 & 0,67 & 3,53 & 74,2 & 68,1 \\
\hline BR 473 (V10) & 185 & 101 & 0,54 & 0,89 & 4,01 & 84,4 & 77,4 \\
\hline BR 451 (V11) & 171 & 81 & 0,47 & 0,86 & 3,69 & 77,6 & 71,1 \\
\hline CMS 455CE (V12) & 168 & 86 & 0,51 & 0,77 & 3,38 & 71,1 & 65,2 \\
\hline Porangatu (V13) & 174 & 94 & 0,54 & 0,85 & 3,49 & 73,3 & 67,3 \\
\hline Suwan 2 (V14) & 181 & 98 & 0,54 & 0,80 & 3,52 & 74,0 & 67,9 \\
\hline Caripeño DMR (V15) & 172 & 94 & 0,55 & 0,69 & 2,73 & 57,4 & 52,7 \\
\hline Caribean DMR (V16) & 168 & 83 & 0,49 & 0,78 & 2,75 & 57,8 & 53,0 \\
\hline Cupurico DMR (V17) & 169 & 91 & 0,54 & 0,86 & 3,60 & 75,7 & 69,4 \\
\hline Tuxpeño Crema I (V18) & 172 & 91 & 0,53 & 0,56 & 2,55 & 53,6 & 49,2 \\
\hline Braciat (V19) & 151 & 77 & 0,51 & 0,71 & 2,91 & 61,3 & 56,2 \\
\hline GI 041 (V20) & 210 & 134 & 0,64 & 0,49 & 1,66 & 34,9 & 32,0 \\
\hline GI 045 (V21) & 184 & 120 & 0,65 & 0,61 & 2,87 & 60,4 & 55,3 \\
\hline PC 9405 (V22) & 184 & 104 & 0,56 & 0,76 & 3,88 & 81,6 & 74,9 \\
\hline IAPAR 15 (V23) & 180 & 105 & 0,58 & 0,66 & 2,25 & 47,3 & 43,3 \\
\hline PMI 9302 (V24) & 164 & 88 & 0,54 & 0,57 & 2,48 & 52,2 & 47,8 \\
\hline Pichilingue (V25) & 161 & 86 & 0,53 & 0,81 & 3,62 & 76,1 & 69,8 \\
\hline Piranão VD2 (V26) & 161 & 84 & 0,52 & 0,68 & 2,20 & 46,2 & 42,4 \\
\hline BR 105 (V27) & 183 & 108 & 0,59 & 0,83 & 3,58 & 75,3 & 69,0 \\
\hline CMS 58ND (V28) & 179 & 91 & 0,51 & 0,75 & 3,58 & 75,2 & 69,0 \\
\hline CMS 59 - S.E. (V29) & 159 & 95 & 0,60 & 0,61 & 2,52 & 53,0 & 48,6 \\
\hline WP 12 (V30) & 208 & 128 & 0,61 & 0,68 & 3,27 & 68,8 & 63,1 \\
\hline ESALQPB $2 \times$ ESALQPB3 (V31) & 175 & 104 & 0,60 & 0,62 & 2,40 & 50,4 & 46,2 \\
\hline CMS 57NF (V32) & 168 & 88 & 0,52 & 0,71 & 3,54 & 74,4 & 68,3 \\
\hline IAPAR 51 (V33) & 168 & 91 & 0,54 & 0,67 & 3,56 & 74,8 & 68,6 \\
\hline PMI 8701 (V34) & 184 & 89 & 0,48 & 0,84 & 4,61 & 97,0 & 88,9 \\
\hline PMI 9401 (V35) & 193 & 118 & 0,61 & 0,70 & 3,64 & 76,5 & 70,2 \\
\hline $\mathrm{V} 1 \times \mathrm{VT}$ & 193 & 116 & 0,59 & 0,84 & 4,40 & 92,6 & 85,0 \\
\hline $\mathrm{V} 2 \times \mathrm{VT}$ & 177 & 99 & 0,56 & 0,68 & 2,98 & 62,6 & 57,4 \\
\hline$V 3 \times V T$ & 194 & 111 & 0,57 & 0,81 & 3,73 & 78,4 & 71,9 \\
\hline$V 4 \times \sqrt{T}$ & 177 & 98 & 0,55 & 0,85 & 4,41 & 92,8 & 85,1 \\
\hline $\mathrm{V} 5 \times \mathrm{VT}$ & 178 & 104 & 0,58 & 0,88 & 4,00 & 84,2 & 77,2 \\
\hline $\mathrm{V} 6 \times \mathrm{VT}$ & 186 & 109 & 0,58 & 0,89 & 4,25 & 89,5 & 82,0 \\
\hline $\mathrm{V} 7 \times \mathrm{VT}$ & 183 & 98 & 0,54 & 0,84 & 4,53 & 95,3 & 87,3 \\
\hline$V 8 \times V T$ & 187 & 105 & 0,56 & 0,87 & 4,95 & 104,2 & 95,6 \\
\hline $\mathrm{V} 9 \times \mathrm{VT}$ & 203 & 120 & 0,58 & 0,75 & 3,85 & 81,1 & 74,3 \\
\hline $\mathrm{V} 10 \times \mathrm{VT}$ & 178 & 95 & 0,53 & 0,85 & 3,93 & 82,6 & 75,7 \\
\hline
\end{tabular}


Tabela 9. Médias das variedades e "topcrosses" intragrupo para altura da planta (AP) e altura da espiga ( $A E$ ), em cm; posição relativa da espiga (PO); índice de espigas (IE); peso de espigas (PE), em t/ha; percentagem do peso de espigas em relação a testemunha 1 $\left(\% T_{1}\right)$ e percentagem do peso de espigas em relação a testemunha $2\left(\% \mathrm{~T}_{2}\right)$, e coeficientes de vari ação experimental (CV). Experimento 3, Anhembi, SP, 1997/98. (Continuação)

\begin{tabular}{|c|c|c|c|c|c|c|c|}
\hline Tratamentos & $\mathrm{AP}$ & $A E$ & PO & IE & $P E$ & $\% T_{1}$ & $\% T_{2}$ \\
\hline $\mathrm{V} 11 \times \mathrm{VT}$ & 179 & 94 & 0,52 & 0,83 & 3,71 & 78,1 & 71,7 \\
\hline $\mathrm{V} 12 \times \mathrm{VT}$ & 174 & 94 & 0,54 & 0,84 & 3,25 & 68,4 & 62,7 \\
\hline $\mathrm{V} 13 \times \mathrm{VT}$ & 178 & 91 & 0,51 & 0,74 & 3,92 & 82,4 & 75,5 \\
\hline $\mathrm{V} 14 \times \mathrm{VT}$ & 195 & 111 & 0,56 & 0,91 & 4,10 & 86,3 & 79,1 \\
\hline $\mathrm{V} 15 \times \mathrm{VT}$ & 199 & 113 & 0,56 & 0,80 & 3,89 & 81,8 & 75,0 \\
\hline $\mathrm{V} 16 \times \mathrm{VT}$ & 187 & 107 & 0,57 & 0,74 & 2,99 & 62,9 & 57,7 \\
\hline $\mathrm{V} 17 \times \mathrm{VT}$ & 179 & 101 & 0,56 & 0,84 & 3,88 & 81,6 & 74,8 \\
\hline $\mathrm{V} 18 \times \mathrm{VT}$ & 184 & 104 & 0,56 & 0,66 & 3,41 & 71,7 & 65,7 \\
\hline $\mathrm{V} 19 \times \mathrm{VT}$ & 182 & 111 & 0,61 & 0,68 & 3,10 & 65,2 & 59,8 \\
\hline $\mathrm{V} 20 \times \mathrm{VT}$ & 200 & 116 & 0,58 & 0,62 & 3,00 & 63,2 & 57,9 \\
\hline $\mathrm{V} 21 \times \mathrm{VT}$ & 190 & 116 & 0,61 & 0,75 & 3,62 & 76,1 & 69,8 \\
\hline $\mathrm{V} 22 \times \mathrm{VT}$ & 196 & 107 & 0,53 & 0,80 & 4,03 & 84,8 & 77,7 \\
\hline $\mathrm{V} 23 \times \mathrm{VT}$ & 189 & 114 & 0,60 & 0,76 & 4,13 & 86,9 & 79,7 \\
\hline$V 24 \times V T$ & 178 & 101 & 0,57 & 0,82 & 3,77 & 79,3 & 72,7 \\
\hline $\mathrm{V} 25 \times \mathrm{VT}$ & 173 & 98 & 0,57 & 0,91 & 3,38 & 71,1 & 65,2 \\
\hline $\mathrm{V} 26 \times \mathrm{VT}$ & 191 & 115 & 0,60 & 1,05 & 3,82 & 80,4 & 73,8 \\
\hline $\mathrm{V} 27 \times \mathrm{VT}$ & 181 & 105 & 0,58 & 0,81 & 3,84 & 80,8 & 74,0 \\
\hline $\mathrm{V} 28 \times \mathrm{VT}$ & 187 & 105 & 0,59 & 0,69 & 3,52 & 74,1 & 67,9 \\
\hline $\mathrm{V} 29 \times \mathrm{VT}$ & 173 & 96 & 0,55 & 0,84 & 3,80 & 80,0 & 73,4 \\
\hline $\mathrm{V} 30 \times \mathrm{VT}$ & 201 & 128 & 0,63 & 0,77 & 3,70 & 77,8 & 71,3 \\
\hline $\mathrm{V} 31 \times \mathrm{VT}$ & 184 & 104 & 0,56 & 0,81 & 4,05 & 85,2 & 78,1 \\
\hline $\mathrm{V} 32 \times \mathrm{VT}$ & 183 & 103 & 0,56 & 0,84 & 4,24 & 89,1 & 81,7 \\
\hline$V 33 \times V T$ & 174 & 84 & 0,48 & 0,74 & 3,78 & 79,5 & 72,9 \\
\hline $\mathrm{V} 34 \times \mathrm{VT}$ & 179 & 104 & 0,58 & 0,87 & 4,13 & 86,8 & 79,6 \\
\hline $\mathrm{V} 35 \times \mathrm{VT}$ & 188 & 112 & 0,59 & 0,70 & 3,91 & 82,2 & 75,4 \\
\hline Média geral & 181 & 102 & 0,56 & 0,77 & 3,55 & 74,7 & 68,5 \\
\hline Média T 1 & 159 & 81 & 0,51 & 0,83 & 4,75 & -- & -- \\
\hline Média $T_{2}$ & 176 & 102 & 0,57 & 0,80 & 5,18 & -- & -- \\
\hline $\mathrm{CV}(\%)$ & 6,4 & 10,8 & 7,5 & 18,9 & 19,6 & -- & -- \\
\hline
\end{tabular}

VT: Mistura das variedades; $T_{1}: A G 6601 ; T_{2}$ : AG 5011. 
Tabela 10. Resumo das análises de variância de "top-cross" intragrupo para altura da planta (AP) e altura da espiga $(A E)$, em $\mathrm{cm}$; e peso de espigas $(P E)$, em t/ha. Experimento 3, Anhembi, SP, 1997/98.

\begin{tabular}{lcccc}
\hline Fontes de variação & GL & \multicolumn{3}{c}{ Quadrados médios } \\
\cline { 3 - 5 } & & AP & AE & PE $\left(10^{5}\right)$ \\
\hline Tratamentos & 69 & $134,760^{\star \star}$ & $149,364^{\star \star}$ & $368,938^{\star \star}$ \\
Variedades & 34 & $215,052^{\star \star}$ & $239,220^{\star \star}$ & $454,663^{\star \star}$ \\
Heterose média & 1 & $1080,357^{\star \star}$ & $630,000^{\star \star}$ & $5312,676^{\star \star}$ \\
Heterose variedades & 34 & $34,440^{\text {ns }}$ & $43,315^{\star}$ & $137,809^{\text {ns }}$ \\
\hline CGC & 34 & $69,542^{\star \star}$ & $82,785^{\star \star}$ & $197,122^{\star \star}$ \\
\hline Resíduo & 207 & 31,077 & 27,146 & 121,780
\end{tabular}

Quadrados médios em nivel de média de repetições.

$\left(10^{3}\right)$ : Quadrados médios multiplicados por $10^{3}$.

ns, ${ }^{\star} e^{\star \star}$ : não significativos, significativos ao nível de $5 \%$ e $1 \%$ de probabilidade, respectivamente. 
Tabela 11. Estimativas dos efeitos de variedades $\left(v_{1}\right)$, heterose de variedades $\left(h_{1}\right)$ e capacidade geral de combinação $\left(g_{1}\right)$, para altura da planta $(A P)$ e altura da espiga $(A E)$, em $\mathrm{cm}$; e peso de espigas (PE), em t/ha. Experimento 3, Anhembi, SP, 1997/98.

\begin{tabular}{|c|c|c|c|c|c|c|c|c|c|}
\hline \multirow[t]{2}{*}{ Variedades } & \multicolumn{3}{|c|}{ AP } & \multicolumn{3}{|c|}{$A E$} & \multicolumn{3}{|c|}{$P E$} \\
\hline & $v_{1}$ & $h_{i}$ & $g_{i}$ & $v_{i}$ & $h_{i}$ & $g_{1}$ & $v_{1}$ & $h_{1}$ & $g$ \\
\hline CMS $4 \mathrm{~N}$ & 5,33 & 5,73 & 8,40 & 8,84 & 6,31 & 10,73 & 0,502 & 0,345 & 0,596 \\
\hline CMS 4C & $-9,17$ & $-3,86$ & $-8,45$ & $-0,56$ & $-6,63$ & $-6,91$ & $-0,232$ & $-0,778$ & $-0,894$ \\
\hline CMS $14 \mathrm{C}$ & 11,83 & 3,24 & 9,16 & 9,44 & 0,66 & 5,38 & 0,135 & $-0,180$ & $-0,112$ \\
\hline CMS 28 & $-12,17$ & $-2,27$ & $-8,36$ & $-13,06$ & $-1,30$ & $-7,83$ & 0,683 & 0,256 & 0,598 \\
\hline BR 106 & 9,63 & $-13,09$ & $-8,28$ & 11,94 & $-7,98$ & $-2,01$ & 0,630 & $-0,151$ & 0,164 \\
\hline BR 111 & 6,53 & $-2,22$ & 1,04 & 7,54 & $-0,35$ & 3,42 & 0,272 & 0,307 & 0,443 \\
\hline CMS 53 & $-9,17$ & 2,18 & $-2,40$ & $-5,56$ & $-4,64$ & $-7,42$ & 0,281 & 0,593 & 0,734 \\
\hline CMS 54 & 7,83 & $-2,06$ & 1,85 & 5,74 & $-3,32$ & $-0,45$ & 0,422 & 0,972 & 1,183 \\
\hline IAPAR 50 & 22,83 & 6,42 & 17,84 & 28,74 & 0,39 & 14,77 & 0,252 & $-0,106$ & 0,020 \\
\hline BR 473 & 7,83 & $-11,50$ & $-7,59$ & 1,34 & $-11,59$ & $-10,92$ & 0,735 & $-0,286$ & 0,082 \\
\hline BR 451 & $-6,17$ & $-3,44$ & $-6,53$ & $-18,66$ & $-2,36$ & $-11,69$ & 0,410 & $-0,337$ & $-0,132$ \\
\hline CMS 455CE & $-9,17$ & $-7,15$ & $-11,74$ & $-13,66$ & $-4,38$ & $-11,21$ & 0,103 & $-0,666$ & $-0,614$ \\
\hline Porangatu & $-3,17$ & $-6,30$ & $-7,89$ & $-4,96$ & $-12,28$ & $-14,76$ & 0,209 & $-0,018$ & 0,087 \\
\hline Suwan 2 & 4,03 & 8,44 & 10,45 & $-1,16$ & 6,28 & 5,70 & 0,242 & 0,161 & 0,282 \\
\hline Caripeño DMR & $-5,17$ & 17,95 & 15,37 & $-4,96$ & 10,31 & 7,83 & $-0,547$ & 0,354 & 0,080 \\
\hline Caribean DMR & $-9,17$ & 6,74 & 2,16 & $-16,76$ & 10,52 & 2,14 & $-0,531$ & $-0,604$ & $-0,870$ \\
\hline Cupurico DMR & $-8,17$ & $-1,74$ & $-5,83$ & $-8,06$ & 0,02 & $-4,01$ & 0,322 & $-0,118$ & 0,043 \\
\hline Tuxpeño Crema I & $-5,17$ & 1,33 & $-1,25$ & $-8,66$ & 2,94 & $-1,39$ & $-0,728$ & $-0,060$ & $-0,424$ \\
\hline Braciat & $-26,17$ & 10,45 & $-2,63$ & $-22,26$ & 17,47 & 6,34 & $-0,363$ & $-0,578$ & $-0,759$ \\
\hline GI 041 & 32,83 & $-1,53$ & 14,88 & 35,04 & $-6,92$ & 10,60 & $-1,615$ & $-0,016$ & $-0,824$ \\
\hline Gl 045 & 7,13 & 1,49 & 5,06 & 20,74 & 0,66 & 11,03 & $-0,408$ & $-0,006$ & $-0,210$ \\
\hline PC 9405 & 7,13 & 8,07 & 11,63 & 4,44 & $-0,72$ & 1,50 & 0,603 & $-0,106$ & 0,196 \\
\hline IAPAR 15 & 2,83 & 2,71 & 4,13 & 5,74 & 5,91 & 8,78 & $-1,030$ & 0,867 & 0,352 \\
\hline PMI 9302 & $-13,17$ & $-1,00$ & $-7,59$ & $-11,16$ & 1,67 & $-3,91$ & $-0,797$ & 0,361 & $-0,037$ \\
\hline Pichilingue & $-16,17$ & $-4,18$ & $-12,27$ & $-13,66$ & $-0,98$ & $-7,81$ & 0,342 & $-0,655$ & $-0,484$ \\
\hline Piranão VD2 & $-16,17$ & 15,12 & 7,04 & $-14,96$ & 18,27 & 10,79 & $-1,079$ & 0,568 & 0,028 \\
\hline BR 105 & 5,93 & $-7,20$ & $-4,24$ & 8,84 & $-4,96$ & $-0,54$ & 0,301 & $-0,148$ & 0,003 \\
\hline CMS 58ND & 1,53 & 1,07 & 1,83 & $-8,06$ & 4,00 & $-0,03$ & 0,299 & $-0,482$ & $-0,333$ \\
\hline CMS 59 & $-18,17$ & $-3,65$ & $-12,74$ & $-4,26$ & $-7,98$ & $-10,11$ & $-0,757$ & 0,376 & $-0,003$ \\
\hline WP 12 & 31,08 & 0,03 & 15,57 & 28,24 & 9,14 & 23,27 & $-0,008$ & $-0,135$ & $-0,139$ \\
\hline ESALQPB2 $\times$ ESALQPB3 & $-2,17$ & $-0,20$ & $-1,29$ & 5,04 & $-4,33$ & $-1,80$ & $-0,879$ & 0,699 & 0,260 \\
\hline CMS 57NF & $-9,17$ & 2,18 & $-2,40$ & $-11,16$ & 2,99 & $-2,59$ & 0,261 & 0,295 & 0,426 \\
\hline IAPAR 51 & $-9,17$ & $-7,15$ & $-11,74$ & $-8,06$ & $-18,59$ & $-22,62$ & 0,278 & $-0,199$ & $-0,059$ \\
\hline PMI 8701 & 7,13 & $-9,86$ & $-6,29$ & $-9,96$ & 4,27 & $-0,71$ & 1,332 & $-0,388$ & 0,278 \\
\hline PMI 9401 & 15,33 & $-4,98$ & 2,69 & 18,24 & $-2,73$ & 6,39 & 0,360 & $-0,104$ & 0,076 \\
\hline$\mu$ & & 177,17 & & & 99,25 & & & 3,277 & \\
\hline $\bar{h}$ & & 8,08 & & & 6,17 & & & 0,566 & \\
\hline
\end{tabular}


Tabela 12. Médias das variedades "per se" para altura da planta (AP) e altura da espiga (AE), em $\mathrm{cm}$; posição relativa da espiga (PO); indice de espigas (IE); peso de espigas (PE), em t/ha; percentagem do peso de espigas em relação a testemunha $1\left(\% T_{1}\right)$ e percentagem do peso de espigas em relação a testemunha $2\left(\% \mathrm{~T}_{2}\right)$, e coeficientes de variação experimental (CV). Experimento 4, Anhembi, SP, 1997/98.

\begin{tabular}{|c|c|c|c|c|c|c|c|}
\hline Tratamentos & AP & $A E$ & $\mathrm{PO}$ & IE & $\mathrm{PE}$ & $\% \mathrm{~T}_{1}$ & $\% \mathrm{~T}_{2}$ \\
\hline BA 166 & 144 & 72 & 0,50 & 0,86 & 2,89 & 61,8 & 56,3 \\
\hline Composto Jaiba III & 164 & 83 & 0,51 & 0,87 & 3,63 & 77,8 & 70,9 \\
\hline SE 025 & 137 & 63 & 0,45 & 0,87 & 3,37 & 72,1 & 65,7 \\
\hline SE 030 & 151 & 78 & 0,51 & 0,86 & 3,38 & 72,4 & 66,0 \\
\hline Composto Jaiba I & 200 & 121 & 0,60 & 0,68 & 2,73 & 58,5 & 53,3 \\
\hline PE 011 & 188 & 118 & 0,63 & 0,66 & 2,38 & 50,8 & 46,3 \\
\hline BA 115 & 183 & 107 & 0,59 & 0,79 & 4,27 & 91,3 & 83,3 \\
\hline BA 035 & 157 & 77 & 0,49 & 0,78 & 1,67 & 35,7 & 32,5 \\
\hline RN 003 & 157 & 72 & 0,46 & 0,84 & 3,17 & 67,8 & 61,8 \\
\hline BA 191 & 156 & 84 & 0,54 & 0,80 & 4,10 & 87,7 & 79,9 \\
\hline BA 176 & 173 & 84 & 0,49 & 0,86 & 4,05 & 86,7 & 79,1 \\
\hline AL 001 & 160 & 78 & 0,48 & 0,82 & 3,34 & 71,4 & 65,1 \\
\hline PE 001 & 188 & 125 & 0,67 & 0,61 & 3,20 & 68,5 & 62,5 \\
\hline BA 094 & 197 & 112 & 0,57 & 0,70 & 3,35 & 71,6 & 65,3 \\
\hline SE 036 & 175 & 89 & 0,51 & 0,87 & 4,98 & 106,6 & 97,2 \\
\hline BA 165 & 179 & 106 & 0,59 & 0,70 & 3,06 & 65,5 & 59,7 \\
\hline WP 32 & 170 & 87 & 0,51 & 0,91 & 4,08 & 87,3 & 79,6 \\
\hline Puebla Grupo 27 & 169 & 91 & 0,54 & 0,92 & 4,05 & 86,7 & 79,1 \\
\hline San Luis Potosi 127 & 203 & 127 & 0,63 & 0,65 & 2,74 & 58,5 & 53,4 \\
\hline PR 053 & 173 & 99 & 0,57 & 0,82 & 3,19 & 68,2 & 62,2 \\
\hline Vera Cruz 212 & 211 & 136 & 0,64 & 0,47 & 2,63 & 56,4 & 51,4 \\
\hline Jamaica 8 & 194 & 121 & 0,63 & 0,50 & 1,49 & 31,8 & 29,0 \\
\hline MS 054 & 190 & 113 & 0,60 & 0,76 & 3,17 & 67,9 & 61,9 \\
\hline Matahambre x Guapira & 203 & 123 & 0,61 & 0,64 & 2,99 & 64,0 & 58,4 \\
\hline CMS 470 & 196 & 122 & 0,62 & 0,70 & 2,92 & 62,5 & 57,0 \\
\hline CMS 471 & 203 & 129 & 0,64 & 0,45 & 2,51 & 53,6 & 48,9 \\
\hline BA 042 & 184 & 102 & 0,55 & 0,56 & 2,59 & 55,4 & 50,6 \\
\hline $1-75-6$ & 198 & 120 & 0,60 & 0,73 & 3,69 & 79,0 & 72,0 \\
\hline CNPH-1 & 193 & 119 & 0,61 & 0,54 & 2,06 & 44,0 & 40,1 \\
\hline CMS 466 & 195 & 111 & 0,57 & 0,65 & 2,62 & 56,1 & 51,2 \\
\hline CMS 21 & 191 & 116 & 0,61 & 0,75 & 3,39 & 72,6 & 66,2 \\
\hline BR 105V & 193 & 116 & 0,60 & 0,83 & 4,31 & 92,2 & 84,0 \\
\hline CMS 05 & 208 & 133 & 0,64 & 0,62 & 3,43 & 73,4 & 66,9 \\
\hline CMS 14 & 205 & 136 & 0,66 & 0,59 & 2,58 & 55,2 & 50,4 \\
\hline Composto. Planta Baixa & 202 & 132 & 0,65 & 0,58 & 2,68 & 57,4 & 52,3 \\
\hline BR $105 \mathrm{MI}$ & 216 & 138 & 0,64 & 0,56 & 3,01 & 64,3 & 58,7 \\
\hline CMS 457 & 193 & 121 & 0,63 & 0,39 & 1,45 & 31,0 & 28,3 \\
\hline SE 033 & 181 & 111 & 0,61 & 0,71 & 3,54 & 75,8 & 69,1 \\
\hline Brasil 2294 & 199 & 121 & 0,61 & 0,44 & 1.52 & 32,6 & 29,7 \\
\hline Mexcla Tropical Blanco & 220 & 146 & 0,66 & 0,70 & 3,52 & 75,2 & 68,6 \\
\hline AL 009 & 198 & 123 & 0,62 & 0,74 & 4,04 & 86,4 & 78,8 \\
\hline Blanco Cristalino & 201 & 123 & 0,61 & 0,54 & 1,84 & 39,3 & 35,8 \\
\hline San Luis Potosi 118 & 204 & 120 & 0,59 & 0,64 & 3,25 & 69,5 & 63,4 \\
\hline MS 010 & 203 & 128 & 0,63 & 0,73 & 3,90 & 83,5 & 76,1 \\
\hline Jamaica 10 & 206 & 138 & 0,67 & 0,38 & 1,84 & 39,4 & 35,9 \\
\hline
\end{tabular}


Tabela 12. Médias das variedades "per se" para altura da planta (AP) e altura da espiga (AE), em $\mathrm{cm}$; posição relativa da espiga (PO); índice de espigas (IE); peso de espigas (PE), em t/ha; percentagem do peso de espigas em relação a testemunha $1\left(\% T_{1}\right)$ e percentagem do peso de espigas em relação a testemunha $2\left(\% \mathrm{~T}_{2}\right)$, e coeficientes de variação experimental (CV). Experimento 4, Anhembi, SP, 1997/98. (Continuação)

\begin{tabular}{lccccccc}
\hline Tratamentos & AP & AE & PO & IE & PE & $\% T_{1}$ & $\% T_{2}$ \\
\hline CMS 50 & 213 & 149 & 0,70 & 0,34 & 1,16 & 24,9 & 22,1 \\
Sikalq & 181 & 100 & 0,55 & 0,79 & 4,22 & 90,3 & 82,7 \\
$73 \times$ (PB2xPB3) & 178 & 98 & 0,55 & 0,81 & 3,86 & 82,7 & 75,5 \\
76 (PB2XPB3) & 176 & 96 & 0,55 & 0,82 & 3,57 & 76,4 & 69,1 \\
$79 \times$ (PB2xPB3) & 180 & 101 & 0,56 & 0,81 & 3,90 & 83,5 & 76,2 \\
\hline Média geral & 186 & 110 & 0,58 & 0,70 & 3,10 & 66,5 & 60,0 \\
\hline Média T1 & 159 & 85 & 0,53 & 0,85 & 4,67 & -- & -- \\
Média T2 & 173 & 99 & 0,57 & 0,82 & 5,12 & - & - \\
\hline CV $\%$ (\%) & 6,1 & 11,4 & 9,6 & 13,7 & 20,7 & -- & -- \\
\hline
\end{tabular}

$T_{1}: A G 6601 ; T_{2}: A G 5011$.

Tabela 13. Resumo das análises de variância de variedades "per se" para altura da planta (AP) e altura da espiga $(A E)$, em $\mathrm{cm}$; e peso de espigas (PE), em t/ha. Experimento 4 , Anhembi, SP, $1997 / 98$.

\begin{tabular}{lcccc}
\hline Fontes de variação & GL & \multicolumn{3}{c}{ Quadrados médios } \\
\cline { 3 - 5 } & & AP & AE & PE \\
\hline Tratamentos & 49 & $1486,135^{\star \star}$ & $1793,319^{\star \star}$ & $2,387^{\star \star}$ \\
Residuo & 147 & 132,528 & 158,516 & 0,336
\end{tabular}

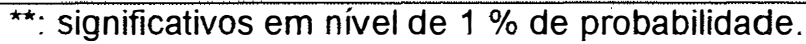


Tabela 14. Médias das variedades "per se" para altura da planta (AP) e altura da espiga (AE), em $\mathrm{cm}$; posição relativa da espiga (PO); índice de espigas (IE); peso de espigas (PE), em t/ha; percentagem do peso de espigas em relação a testemunha $1\left(\% T_{1}\right)$ e percentagem do peso de espigas em relação a testemunha $2\left(\% \mathrm{~T}_{2}\right)$, e coeficientes de variação experimental (CV). Experimento 5, Anhembi, SP, 1997/98.

\begin{tabular}{|c|c|c|c|c|c|c|c|}
\hline Tratamentos & AP & $A E$ & $\mathrm{PO}$ & IE & $P E$ & $\% T_{1}$ & $\% T_{2}$ \\
\hline BS $11 \times$ BR 105 & 176 & 97 & 0,55 & 0,61 & 2,37 & 56,3 & 52,8 \\
\hline (Guadalupe $5 \times$ Mo 17) x BR 105 & 170 & 97 & 0,56 & 0,79 & 2,98 & 70,9 & 66,5 \\
\hline BS $28 \times$ BR 105 & 170 & 97 & 0,56 & 0,75 & 2,92 & 69,6 & 65,2 \\
\hline lodent x BR 105 & 161 & 81 & 0,50 & 0,70 & 2,64 & 62,7 & 58,8 \\
\hline BS $29 \times$ BR 105 & 166 & 92 & 0,55 & 0,78 & 3,27 & 77,8 & 72,9 \\
\hline$($ ARZM $03056 \times$ Mo 17) $\times$ BR 105 & 179 & 100 & 0,55 & 0,63 & 2,61 & 62,2 & 58,3 \\
\hline$(B U I 103 \times B 73) \times B R 105$ & 188 & 107 & 0,56 & 0,79 & 3,28 & 78,0 & 73,1 \\
\hline (Antigua 3 x Mo 17) x BR 105 & 185 & 116 & 0,61 & 0,66 & 2,88 & 68,6 & 64,3 \\
\hline BS $16 \times$ BR 105 & 169 & 96 & 0,56 & 0,77 & 4,06 & 96,7 & 90,6 \\
\hline (Cuba $173 \times$ B 73) $\times$ BR 105 & 173 & 97 & 0,56 & 0,85 & 3,02 & 71,8 & 67,3 \\
\hline Antigua 3 x BR 105 & 183 & 103 & 0,55 & 0,81 & 3,24 & 77,2 & 72,4 \\
\hline (Cuba 117 x B 73) x BR 105 & 169 & 88 & 0,51 & 0,86 & 3,74 & 89,0 & 83,5 \\
\hline (Cuba $110 \times$ Mo 17) x BR 105 & 180 & 92 & 0,51 & 0,82 & 3,72 & 88,6 & 83,0 \\
\hline (Rep. Dom ${ }^{1} .269 \times$ B 73) x BR 105 & 188 & 109 & 0,58 & 0,87 & 3,34 & 79,4 & 74,4 \\
\hline (Mexican Dent x BS 26) x BR 105 & 167 & 80 & 0,48 & 0,74 & 3,40 & 81,0 & 75,9 \\
\hline BS 11 x BR 106 & 170 & 90 & 0,53 & 0,80 & 3,27 & 77,8 & 73,0 \\
\hline (Guadalupe $5 \times$ Mo 17) x BR 106 & 175 & 93 & 0,53 & 0,79 & 3,38 & 80,3 & 75,3 \\
\hline BS 28 x BR 106 & 175 & 91 & 0,52 & 0,74 & 3,31 & 78,8 & 73,8 \\
\hline lodent x BR 106 & 192 & 111 & 0,58 & 0,65 & 3,56 & 84,8 & 79,5 \\
\hline BS 29 x BR 106 & 185 & 97 & 0,52 & 0,73 & 3,52 & 83,7 & 78,5 \\
\hline$(A R Z M 03056 \times$ Mo 17) $\times$ BR 106 & 177 & 103 & 0,57 & 0,68 & 2,52 & 60,0 & 56,3 \\
\hline (BUI 103 × B 73) x BR 106 & 179 & 101 & 0,56 & 0,72 & 3,17 & 75,4 & 70,7 \\
\hline (Antigua $3 \times$ Mo 17) x BR 106 & 166 & 91 & 0,55 & 0,76 & 2,43 & 57,9 & 54,2 \\
\hline BS 16 x BR 106 & 175 & 83 & 0,47 & 0,77 & 3,42 & 81,3 & 76,2 \\
\hline (Cuba $173 \times$ B 73) x BR 106 & 170 & 103 & 0,60 & 0,81 & 4,36 & 103,7 & 97,2 \\
\hline Antigua 3 x BR 106 & 170 & 97 & 0,57 & 0,69 & 3,65 & 86,8 & 81,3 \\
\hline (Cuba $117 \times$ B 73) x BR 106 & 180 & 97 & 0,53 & 0,81 & 3,73 & 88,9 & 83,3 \\
\hline (Cuba 110 × Mo 17) x BR 106 & 175 & 93 & 0,53 & 0,68 & 3,03 & 72,03 & 67,5 \\
\hline (Rep. Dom . $269 \times$ B 73) x BR 106 & 181 & 97 & 0,53 & 0,80 & 3,58 & 85,2 & 79,9 \\
\hline (Mexican Dent x BS 26) x BR 106 & 149 & 73 & 0,49 & 0,76 & 3,12 & 74,1 & 69,5 \\
\hline CMS 13 & 183 & 113 & 0,61 & 0,60 & 2,60 & 61,8 & 57,9 \\
\hline CMS 39 & 176 & 93 & 0,52 & 0,84 & 4,47 & 106,4 & 99,8 \\
\hline CMS 454 & 178 & 97 & 0,54 & 0,77 & 3,33 & 79,2 & 74,2 \\
\hline CMS 463 & 168 & 92 & 0,55 & 0,92 & 4,43 & 105,4 & 98,8 \\
\hline Rep. Dom ${ }^{1} .300$ & 170 & 94 & 0,54 & 0,80 & 2,93 & 69,7 & 65,3 \\
\hline CMS 458 & 164 & 90 & 0,55 & 0,67 & 3,22 & 76,7 & 71,9 \\
\hline Puerto Rico 5 & 174 & 101 & 0,58 & 0,77 & 2,93 & 69,8 & 65,4 \\
\hline CMS 24 & 183 & 114 & 0,62 & 0,64 & 3,06 & 72,7 & 68,2 \\
\hline Suwan DMR Original & 180 & 104 & 0,57 & 0,69 & 3,04 & 72,2 & 67,7 \\
\hline MG 106 & 180 & 99 & 0,55 & 0,62 & 2,45 & 58,3 & 54,7 \\
\hline SE 032 & 174 & 95 & 0,54 & 0,72 & 3,03 & 72,1 & 67,6 \\
\hline BA 044 & 173 & 112 & 0,63 & 0,61 & 2,53 & 60,2 & 56,4 \\
\hline MG 014 & 180 & 103 & 0,57 & 0,74 & 3,17 & 75,4 & 70,7 \\
\hline BA 032 & 185 & 111 & 0,59 & 0,77 & 3,16 & 75,3 & 70,5 \\
\hline BA 187 & 182 & 97 & 0,52 & 0,63 & 2,81 & 66,8 & 62,6 \\
\hline
\end{tabular}


Tabela 14. Médias das variedades "per se" para altura da planta (AP) e altura da espiga (AE), em $\mathrm{cm}$; posição relativa da espiga (PO); índice de espigas (IE); peso de espigas (PE), em tha; percentagem do peso de espigas em relação a testemunha $1\left(\% T_{1}\right)$ e percentagem do peso de espigas em relação a testemunha $2\left(\% \mathrm{~T}_{2}\right)$, e coeficientes de variação experimental (CV). Experimento 5, Anhembi, SP, 1997/98. (Continuação)

\begin{tabular}{lccccccc}
\hline Tratamentos & AP & AE & PO & IE & PE & $\% T_{1}$ & $\% T_{2}$ \\
\hline BA 159 & 199 & 114 & 0,57 & 0,55 & 2,98 & 71,0 & 66,5 \\
MAYA XVIII & 186 & 117 & 0,61 & 0,63 & 2,22 & 52,8 & 49,5 \\
PE 025 & 180 & 109 & 0,59 & 0,65 & 2,43 & 57,8 & 54,2 \\
Cateto Colômbia VIII & 188 & 110 & 0,57 & 0,69 & 3,02 & 72,0 & 67,5 \\
PE 028 & 191 & 116 & 0,60 & 0,63 & 3,49 & 83,0 & 77,8 \\
\hline Média geral & 176 & 99 & 0,55 & 0,73 & 3,17 & 75,6 & 70,8 \\
\hline Média T1 & 169 & 87 & 0,51 & 0,81 & 4,20 & - & -- \\
Média T2 & 179 & 104 & 0,57 & 0,74 & 4,48 & -- & -- \\
\hline CV (\%) & 8,1 & 16,3 & 10,7 & 18,0 & 17,4 & -- & -- \\
\hline
\end{tabular}

'República Dominicana; $T_{1}$ : AG 6601; $T_{2}$ : AG 5011.

Tabela 15. Resumo das análises de variância de variedades "per se" para altura da planta (AP) e altura da espiga $(A E)$, em cm; e peso de espigas (PE), em t/ha. Experimento 5, Anhembi, SP, $1997 / 98$.

\begin{tabular}{lcccc}
\hline Fontes de variação & GL & \multicolumn{3}{c}{ Quadrados médios } \\
\cline { 3 - 5 } & & AP & AE & PE \\
\hline Tratamentos & 49 & $481,091^{\star \star}$ & $558,902^{\star \star}$ & $0,978^{\star \star}$ \\
Resíduo & 147 & 212,442 & 271,843 & 0,249
\end{tabular}

: significativos em nível de $1 \%$ de probabilidade. 
Tabela 16. Médias das variedades para comprimento líquido de radícula $(\mathrm{CL}), \mathrm{em} \mathrm{cm}$; comprimento líquido de radícula relativo a testemunha tolerante (CLRTT) e comprimento líquido de radícula relativo a testemunha sensível (CLRTS), e coeficientes de variação experimental (CV). Experimento 6, Campinas. SP, 1998.

\begin{tabular}{|c|c|c|c|}
\hline Variedades & $\mathrm{CL}$ & CLRTT & CLRTS \\
\hline Taitinga & 13,44 & 0,91 & 2,26 \\
\hline Taiúba & 12,60 & 0,85 & 2,12 \\
\hline Cupurico DMR & 10,48 & 0,71 & 1,76 \\
\hline Tuxpeño amarillo & 8,71 & 0,59 & 1,47 \\
\hline WP 12 & 9,67 & 0,65 & 1,63 \\
\hline PMI 8701 & 9,05 & 0,61 & 1,52 \\
\hline CMS 56NF & 10,98 & 0,74 & 1,85 \\
\hline CMS 53 & 10,47 & 0,71 & 1,76 \\
\hline CMS 28 & 8,35 & 0,56 & 1,41 \\
\hline CMS 54 & 9,09 & 0,61 & 1,53 \\
\hline CMS 04N & 7,68 & 0,52 & 1,29 \\
\hline BR 111 & 9,79 & 0,66 & 1,65 \\
\hline Suwan 2 & 11,95 & 0,81 & 2,01 \\
\hline PC 9405 & 9,37 & 0,63 & 1,58 \\
\hline CMS 39 & 11,53 & 0,78 & 1,94 \\
\hline CMS 463 & 8,32 & 0,56 & 1,40 \\
\hline Sikalq & 12,77 & 0,86 & 2,15 \\
\hline MS 010 & 6,37 & 0,43 & 1,07 \\
\hline SE 036 & 7,90 & 0,53 & 1,33 \\
\hline BA 115 & 8,37 & 0,57 & 1,41 \\
\hline BR 105 & 12,19 & 0,82 & 2,05 \\
\hline WP 32 & 9,61 & 0,65 & 1,62 \\
\hline BA 191 & 7,37 & 0,50 & 1,24 \\
\hline AL 009 & 10,78 & 0,73 & 1,82 \\
\hline Puebla Grupo 27 & 7,74 & 0,52 & 1,30 \\
\hline BA 176 & 6,69 & 0,45 & 1,13 \\
\hline (Cuba $173 \times$ B 73) x BR 106 & 8,53 & 0,58 & 1,44 \\
\hline BS $16 \times$ BR 105 & 7,56 & 0,51 & 1,27 \\
\hline (Cuba $117 \times$ B 73) $\times$ BR 106 & 6,36 & 0,43 & 1,07 \\
\hline (Cuba $117 \times$ B 73) × BR 105 & 7,90 & 0,53 & 1,33 \\
\hline (Cuba $110 \times$ Mo 17) x BR 105 & 8,29 & 0,56 & 1,40 \\
\hline Antigua $3 \times$ BR 106 & 7,66 & 0,52 & 1,29 \\
\hline BS $29 \times$ BR 106 & 9,21 & 0,62 & 1,55 \\
\hline lodent $\times$ BR 106 & 7,62 & 0,52 & 1,28 \\
\hline Média variedades & 9,24 & 0,62 & 1,55 \\
\hline Média TT & 14,77 & $\cdots$ & $\cdots$ \\
\hline Média TS & 5,94 & --- & --- \\
\hline CV $(\%)$ & 11,4 & 12,6 & 15,7 \\
\hline
\end{tabular}

Testemunha tolerante (TT): DINA 766; Testemunha sensível (TS): MITLA 9560. 
Tabela 17. Resumos das análises de variância para comprimento líquido de radícula (CL), em $\mathrm{cm}$; comprimento líquido de radicula relativo a testemunha tolerante (CLRTT) e comprimento líquido de radícula relativo a testemunha sensivel. Experimento 6 , Campinas, SP, 1998.

\begin{tabular}{lcccc}
\hline Fontes de variação & $G L$ & \multicolumn{3}{c}{ Quadrados médios } \\
\cline { 3 - 5 } & & $C L$ & CLRTT & CLRTS \\
\hline Variedades & 33 & $1118,085^{\star \star}$ & $0,111^{\star \star}$ & $0,269^{\star \star}$ \\
Resíduo & 66 & 115,029 & 0,006 & 0,062
\end{tabular}

«*: significativos em nível de $1 \%$ de probabilidade. 
Tabela 18. Médias das variedades e híbridos para altura da planta (AP) e altura da espiga (AE), em $\mathrm{cm}$; percentagem de plantas acamadas (\%AC); percentagem de plantas quebradas $(\% P Q)$ e dias para florescimento masculino (DF), e coeficientes de variação experimental (CV). Experimento 7, Anhembi, SP, 1998/99.

\begin{tabular}{|c|c|c|c|c|c|}
\hline Tratamentos & $A P$ & $A E$ & $\% A C$ & $\% P Q$ & DF \\
\hline Taitinga (V1) & 198 & 104 & 3,4 & 4,4 & 61 \\
\hline Taiúba (V2) & 194 & 104 & 0,5 & 6,0 & 60 \\
\hline Cupurico DMR (V3) & 181 & 98 & 2,4 & 12,7 & 61 \\
\hline CMS 53 (V4) & 185 & 98 & 0,0 & 3,0 & 60 \\
\hline Suwan 2 (V5) & 194 & 105 & 0,5 & 6,6 & 61 \\
\hline Sikalq (V6) & 189 & 104 & 0,4 & 8,2 & 59 \\
\hline CMS 39 (V7) & 210 & 120 & 1,6 & 8,6 & 69 \\
\hline BR 105 (V8) & 198 & 111 & 3,0 & 5,1 & 65 \\
\hline AL 009 (V9) & 200 & 114 & 2,3 & 9,3 & 71 \\
\hline CMS 57NF (V10) & 163 & 86 & 1,0 & 4,6 & 62 \\
\hline $\mathrm{V} 1 \times \mathrm{V} 2$ & 194 & 104 & 0,9 & 11,4 & 63 \\
\hline $\mathrm{V} 1 \times \mathrm{V} 3$ & 193 & 101 & 0,9 & 4,2 & 60 \\
\hline $\mathrm{V} 1 \times \mathrm{V} 4$ & 185 & 97 & 0,4 & 7,4 & 60 \\
\hline $\mathrm{V} 1 \times \mathrm{V} 5$ & 194 & 103 & 0,4 & 10,4 & 61 \\
\hline V1 $\times$ V6 & 193 & 102 & 1,0 & 10,0 & 60 \\
\hline$\vee 1 \times \vee 7$ & 213 & 117 & 0,9 & 4,8 & 64 \\
\hline V1 $\times$ V8 & 202 & 109 & 3,0 & 8,9 & 62 \\
\hline V1 x V9 & 208 & 118 & 0,9 & 9,5 & 63 \\
\hline $\mathrm{V} 1 \times \mathrm{V} 10$ & 174 & 88 & 0,9 & 5,9 & 63 \\
\hline V2 x V3 & 188 & 100 & 0,0 & 8,0 & 62 \\
\hline $\mathrm{V} 2 \times \mathrm{V} 4$ & 185 & 96 & 1,9 & 4,0 & 60 \\
\hline $\mathrm{V} 2 \times \mathrm{V} 5$ & 190 & 100 & 1,6 & 4,9 & 61 \\
\hline $\mathrm{V} 2 \times \mathrm{V} 6$ & 187 & 100 & 1,0 & 7,8 & 61 \\
\hline $\mathrm{V} 2 \times \mathrm{V} 7$ & 197 & 109 & 1,5 & 7,0 & 66 \\
\hline $\mathrm{V} 2 \times \mathrm{V} 8$ & 195 & 111 & 1,8 & 8,0 & 62 \\
\hline V2 x V9 & 212 & 117 & 2,7 & 6,7 & 67 \\
\hline $\mathrm{V} 2 \times \mathrm{V} 10$ & 184 & 95 & 1,9 & 1,4 & 61 \\
\hline V3 x V4 & 183 & 94 & 0,0 & 8,5 & 60 \\
\hline $\mathrm{V} 3 \times \mathrm{V} 5$ & 197 & 103 & 0,0 & 5,6 & 61 \\
\hline $\mathrm{V} 3 \times \mathrm{V} 6$ & 189 & 103 & 0,9 & 4,6 & 60 \\
\hline V3 $\times$ V7 & 208 & 116 & 4,8 & 13,4 & 65 \\
\hline V3 $\times$ V8 & 201 & 115 & 3,1 & 4,3 & 65 \\
\hline V3 x V9 & 207 & 114 & 1,9 & 3,2 & 64 \\
\hline$\vee 3 \times \vee 10$ & 193 & 101 & 0,0 & 5,7 & 60 \\
\hline V4 x V5 & 188 & 97 & 1,3 & 1,5 & 61 \\
\hline $\mathrm{V} 4 \times \mathrm{V} 6$ & 192 & 103 & 1,0 & 5,8 & 60 \\
\hline V4 x V7 & 203 & 112 & 0,9 & 5,2 & 62 \\
\hline V4 x V8 & 191 & 106 & 1,1 & 3,1 & 61 \\
\hline V4 × V9 & 196 & 106 & 0,5 & 7,0 & 65 \\
\hline $\mathrm{V} 4 \times \mathrm{V} 10$ & 180 & 93 & 0,0 & 6,2 & 59 \\
\hline V5 x V6 & 181 & 96 & 1,6 & 10,2 & 61 \\
\hline $\mathrm{V} 5 \times \mathrm{V} 7$ & 188 & 101 & 0,9 & 6,9 & 63 \\
\hline V5 x V8 & 204 & 115 & 0,0 & 4,7 & 62 \\
\hline V5 x V9 & 209 & 118 & 0,9 & 6,0 & 62 \\
\hline V5 x V10 & 196 & 104 & 1,4 & 4,7 & 60 \\
\hline
\end{tabular}


Tabela 18. Médias das variedades e hibridos para altura da planta (AP) e altura da espiga (AE), em $\mathrm{cm}$; percentagem de plantas acamadas $(\% A C)$; percentagem de plantas quebradas $(\% P Q)$ e dias para florescimento masculino (DF), e coeficientes de variação experimental (CV). Experimento 7. Anhembi, SP, 1998/99. (Continuação)

\begin{tabular}{|c|c|c|c|c|c|}
\hline Tratamentos & AP & $A E$ & $\% A C$ & $\% P Q$ & DF \\
\hline $\mathrm{V} 6 \times \mathrm{V} 7$ & 207 & 116 & 2,2 & 18,1 & 64 \\
\hline V6 $\times$ V8 & 196 & 110 & 1,0 & 3,3 & 61 \\
\hline V6 $\times$ V9 & 209 & 120 & 1,0 & 3,5 & 66 \\
\hline $\mathrm{V} 6 \times \mathrm{V} 10$ & 185 & 97 & 2,4 & 7,8 & 60 \\
\hline V7 x V8 & 197 & 112 & 1,6 & 4,4 & 67 \\
\hline V7 x V9 & 208 & 120 & 3,7 & 10,3 & 67 \\
\hline$\vee 7 \times \vee 10$ & 196 & 106 & 3,1 & 10,8 & 64 \\
\hline V8 x V9 & 214 & 126 & 0,0 & 3,4 & 65 \\
\hline $\mathrm{V} 8 \times \mathrm{V} 10$ & 197 & 109 & 0,5 & 4,5 & 61 \\
\hline $\mathrm{V} 9 \times \mathrm{V} 10$ & 192 & 105 & 1,0 & 5,2 & 63 \\
\hline Média geral & 195 & 106 & 1,3 & 6,7 & 62 \\
\hline Média $T_{1}$ & 165 & 95 & 0,3 & 1,1 & 62 \\
\hline Média $T_{2}$ & 175 & 90 & 0,0 & 1,0 & 62 \\
\hline $\mathrm{CV}(\%)$ & 6,2 & 8,7 & - & -- & - \\
\hline
\end{tabular}

$\mathrm{T}_{1}$ : Dina 766; $\mathrm{T}_{2}$ : Mitla 9560. 
Tabela 19. Médias das variedades e híbridos para altura da planta (AP) e altura da espiga (AE), em $\mathrm{cm}$; percentagem de plantas acamadas (\%AC); percentagem de plantas quebradas (\%PQ) e dias para florescimento masculino (DF), e coeficientes de variação experimental (CV). Experimento 8. Anhembi, SP, 1998/99.

\begin{tabular}{|c|c|c|c|c|c|}
\hline Tratamentos & AP & $\mathrm{AE}$ & $\% A C$ & $\% P Q$ & DF \\
\hline Taitinga (V1) & 212 & 113 & 0,0 & 5,9 & 60 \\
\hline Taiúba (V2) & 205 & 116 & 0,0 & 8,0 & 62 \\
\hline Cupurico DMR (V3) & 205 & 114 & 0,0 & 5,7 & 61 \\
\hline CMS 53 (V4) & 204 & 111 & 1,4 & 1,8 & 59 \\
\hline Suwan 2 (V5) & 214 & 121 & 0,6 & 6,3 & 61 \\
\hline Sikalq (V6) & 199 & 107 & 1,1 & 10,1 & 58 \\
\hline CMS 39 (V7) & 236 & 140 & 0,5 & 8,8 & 67 \\
\hline BR 105 (V8) & 218 & 130 & 0,0 & 19,4 & 65 \\
\hline AL 009 (V9) & 230 & 139 & 0,7 & 11,4 & 68 \\
\hline CMS 57NF (V10) & 188 & 101 & 0,5 & 0,5 & 60 \\
\hline $\mathrm{V} 1 \times \mathrm{V} 2$ & 215 & 122 & 0,0 & 9,9 & 62 \\
\hline $\mathrm{V} 1 \times \mathrm{V} 3$ & 211 & 115 & 0,0 & 7,8 & 61 \\
\hline$\vee 1 \times \vee 4$ & 201 & 110 & 0,0 & 1,0 & 61 \\
\hline$\vee 1 \times \vee 5$ & 218 & 125 & 0,5 & 8,6 & 60 \\
\hline $\mathrm{V} 1 \times \mathrm{V} 6$ & 213 & 119 & 1,4 & 10,0 & 59 \\
\hline $\mathrm{V} 1 \times \mathrm{V} 7$ & 235 & 138 & 0,0 & 6,8 & 65 \\
\hline$\vee 1 \times \vee 8$ & 215 & 118 & 0,0 & 3,8 & 63 \\
\hline $\mathrm{V} 1 \times \mathrm{V} 9$ & 232 & 137 & 0,6 & 7,2 & 63 \\
\hline$V_{1} \times V_{10}$ & 202 & 111 & 0,0 & 1,6 & 60 \\
\hline$\vee 2 \times \vee 3$ & 204 & 111 & 0,4 & 2,4 & 62 \\
\hline$\vee 2 \times \vee 4$ & 206 & 114 & 0,0 & 2,6 & 59 \\
\hline$\vee 2 \times \vee 5$ & 211 & 116 & 0,5 & 10,0 & 59 \\
\hline $\mathrm{V} 2 \times \mathrm{V} 6$ & 210 & 119 & 0,0 & 9,8 & 60 \\
\hline $\mathrm{V} 2 \times \mathrm{V} 7$ & 224 & 134 & 0,0 & 23,4 & 67 \\
\hline$\vee 2 \times \vee 8$ & 223 & 132 & 0,0 & 12,5 & 63 \\
\hline $\mathrm{V} 2 \times \mathrm{V} 9$ & 237 & 143 & 0,4 & 8,5 & 66 \\
\hline $\mathrm{V} 2 \times \mathrm{V} 10$ & 200 & 115 & 0,0 & 4,3 & 61 \\
\hline $\mathrm{V} 3 \times \mathrm{V} 4$ & 202 & 105 & 0,4 & 12,3 & 59 \\
\hline$\vee 3 \times \vee 5$ & 210 & 111 & 0,5 & 5,8 & 60 \\
\hline $\mathrm{V} 3 \times \mathrm{V} 6$ & 225 & 118 & 0,4 & 4,3 & 59 \\
\hline$\vee 3 \times \vee 7$ & 221 & 132 & 1,5 & 10,7 & 66 \\
\hline V3 $\times$ V8 & 227 & 130 & 0,9 & 5,9 & 62 \\
\hline V3 $\times$ V9 & 200 & 132 & 0,4 & 4,5 & 64 \\
\hline$\vee 3 \times \vee 10$ & 216 & 109 & 0,4 & 7,7 & 60 \\
\hline$\vee 4 \times \vee 5$ & 209 & 122 & 1,5 & 1,5 & 60 \\
\hline V4 $\times$ V6 & 222 & 120 & 0,4 & 2,7 & 59 \\
\hline$\vee 4 \times \vee 7$ & 217 & 124 & 1,3 & 2,1 & 62 \\
\hline V4 x V8 & 222 & 130 & 0,0 & 12,7 & 61 \\
\hline V4 x V9 & 202 & 128 & 0,4 & 3,6 & 65 \\
\hline$\vee 4 \times \vee 10$ & 207 & 110 & 1,0 & 8,7 & 59 \\
\hline V5 x V6 & 232 & 116 & 1,9 & 6,7 & 59 \\
\hline$\vee 5 \times \vee 7$ & 225 & 133 & 0,5 & 2,7 & 62 \\
\hline V5 $\times$ V8 & 227 & 129 & 1,0 & 14,4 & 60 \\
\hline V5 x V9 & 216 & 134 & 0,9 & 10,7 & 62 \\
\hline $\mathrm{V} 5 \times \mathrm{V} 10$ & 220 & 116 & 0,5 & 0,2 & 60 \\
\hline
\end{tabular}


Tabela 19. Médias das variedades e híbridos para altura da planta (AP) e altura da espiga (AE), em $\mathrm{cm}$; percentagem de plantas acamadas $(\% \mathrm{AC})$; percentagem de plantas quebradas $(\% P Q)$ e dias para florescimento masculino (DF), e coeficientes de variação experimental (CV). Experimento 8, Anhembi, SP, 1998/99. (Continuação)

\begin{tabular}{|c|c|c|c|c|c|}
\hline Tratamentos & AP & $A E$ & $\% A C$ & $\% P Q$ & DF \\
\hline $\mathrm{V} 6 \times \mathrm{V} 7$ & 217 & 125 & 0,0 & 18,4 & 64 \\
\hline $\mathrm{V} 6 \times \mathrm{V} 8$ & 212 & 126 & 0,5 & 11,7 & 60 \\
\hline $\mathrm{V} 6 \times \mathrm{V} 9$ & 234 & 145 & 0,5 & 5,4 & 65 \\
\hline $\mathrm{V} 6 \times \mathrm{V} 10$ & 207 & 117 & 0,0 & 10,8 & 59 \\
\hline V7 x V8 & 228 & 138 & 0,5 & 7,2 & 68 \\
\hline V7 × V9 & 243 & 149 & 0,0 & 5,0 & 67 \\
\hline$V 7 \times \vee 10$ & 218 & 122 & 0,4 & 6,9 & 62 \\
\hline V8 x V9 & 232 & 142 & 0,0 & 2,8 & 64 \\
\hline$\vee 8 \times V 10$ & 216 & 121 & 0,5 & 12,0 & 62 \\
\hline $\mathrm{V} 9 \times \mathrm{V} 10$ & 224 & 131 & 0,5 & 3,6 & 63 \\
\hline Média geral & 216 & 123 & 0,4 & 7,4 & 62 \\
\hline Média $\bar{T}_{1}$ & 191 & 107 & 0,6 & 1,3 & 60 \\
\hline Média $T_{2}$ & 198 & 111 & 0,6 & 3.7 & 59 \\
\hline CVe (\%) & 5,0 & 7,2 & - & -- & -- \\
\hline
\end{tabular}

$T_{1}$ : Dina $766 ; T_{2}:$ Mitla 9560. 
Tabela 20. Médias conjuntas das variedades e híbridos para altura da planta (AP) e alt ura da espiga (AE), em $\mathrm{cm}$; percentagem de plant as acamadas $(\% A C)$; percentagem de plant as quebradas (\%PQ) e dias para floresciment o masculino (DF), e coeficient es de vari ação experimental (CV). Experiment os 7 e 8, Anhembi, SP. 1998/99.

\begin{tabular}{|c|c|c|c|c|c|}
\hline Trat ament os & AP & $A E$ & $\% A C$ & $\% P Q$ & DF \\
\hline Taitinga (V1) & 205 & 109 & 1,7 & 5,1 & 60 \\
\hline Taiúba (V2) & 200 & 110 & 0,2 & 7,0 & 61 \\
\hline Cupurico DMR (V3) & 193 & 106 & 1,2 & 9,2 & 60 \\
\hline CMS 53 (V4) & 195 & 104 & 0,7 & 2,4 & 59 \\
\hline Suwan 2 (V5) & 204 & 113 & 0,5 & 6,4 & 60 \\
\hline Sikalq (V6) & 194 & 106 & 0,8 & 9,2 & 58 \\
\hline CMS 39 (V7) & 223 & 130 & 1,0 & 8,7 & 68 \\
\hline BR 105 (V8) & 208 & 121 & 1,5 & 12,3 & 65 \\
\hline AL 009 (V9) & 215 & 127 & 1,5 & 10,3 & 69 \\
\hline CMS 57NF (V10) & 176 & 94 & 0,7 & 2,6 & 61 \\
\hline $\mathrm{V} 1 \times \mathrm{V} 2$ & 205 & 113 & 0,5 & 10,7 & 62 \\
\hline $\mathrm{V} 1 \times \mathrm{V} 3$ & 202 & 108 & 0,4 & 6,0 & 60 \\
\hline $\mathrm{V} 1 \times \mathrm{V} 4$ & 193 & 104 & 0,2 & 4,2 & 60 \\
\hline $\mathrm{V} 1 \times \mathrm{V} 5$ & 206 & 114 & 0,5 & 9,5 & 60 \\
\hline $\mathrm{V} 1 \times \mathrm{V} 6$ & 203 & 111 & 1,2 & 10,0 & 59 \\
\hline $\mathrm{V} 1 \times \mathrm{V} 7$ & 224 & 128 & 0,4 & 5,8 & 64 \\
\hline $\mathrm{V} 1 \times \mathrm{V} 8$ & 208 & 113 & 1,5 & 6,3 & 62 \\
\hline $\mathrm{V} 1 \times \mathrm{V} 9$ & 220 & 128 & 0,7 & 8,3 & 63 \\
\hline $\mathrm{V} 1 \times \mathrm{V} 10$ & 188 & 100 & 0,4 & 3,7 & 61 \\
\hline V2 x V3 & 196 & 106 & 0,2 & 5,2 & 61 \\
\hline $\mathrm{V} 2 \times \mathrm{V} 4$ & 196 & 105 & 0,9 & 3,3 & 59 \\
\hline $\mathrm{V} 2 \times \mathrm{V} 5$ & 200 & 108 & 1,1 & 7,4 & 60 \\
\hline $\mathrm{V} 2 \times \mathrm{V} 6$ & 199 & 110 & 0,5 & 8,8 & 60 \\
\hline $\mathrm{V} 2 \times \mathrm{V} 7$ & 211 & 122 & 0,7 & 15,2 & 67 \\
\hline $\mathrm{V} 2 \times \mathrm{V} 8$ & 209 & 121 & 0,9 & 10,3 & 62 \\
\hline $\mathrm{V} 2 \times \mathrm{V} 9$ & 225 & 130 & 1,6 & 7,6 & 66 \\
\hline $\mathrm{V} 2 \times \mathrm{V} 10$ & 202 & 105 & 1,0 & 2,8 & 60 \\
\hline V3 x V4 & 191 & 100 & 0,2 & 10,4 & 59 \\
\hline$\vee 3 \times \vee 5$ & 200 & 107 & 0,2 & 5,7 & 60 \\
\hline $\mathrm{V} 3 \times \mathrm{V} 6$ & 200 & 111 & 0,7 & 4,5 & 59 \\
\hline$\vee 3 \times \vee 7$ & 217 & 124 & 3,2 & 12,0 & 66 \\
\hline $\mathrm{V} 3 \times \mathrm{V} 8$ & 211 & 122 & 2,0 & 5,1 & 63 \\
\hline $\mathrm{V} 3 \times \mathrm{V} 9$ & 217 & 123 & 1,2 & 3.9 & 64 \\
\hline $\mathrm{V} 3 \times \mathrm{V} 10$ & 196 & 105 & 0,2 & 6,7 & 59 \\
\hline V4 x V5 & 203 & 110 & 1,4 & 1,5 & 60 \\
\hline $\mathrm{V} 4 \times \mathrm{V} 6$ & 201 & 112 & 0,7 & 4,3 & 59 \\
\hline$\vee 4 \times \vee 7$ & 213 & 118 & 1,1 & 3,6 & 61 \\
\hline$V 4 \times \vee 8$ & 204 & 118 & 0,5 & 7,9 & 60 \\
\hline$\vee 4 \times \vee 9$ & 209 & 117 & 0,4 & 5,3 & 65 \\
\hline$\vee 4 \times \vee 10$ & 191 & 102 & 0,5 & 7,4 & 59 \\
\hline V5 $\times$ V6 & 194 & 106 & 1,8 & 8,4 & 60 \\
\hline $\mathrm{V} 5 \times \mathrm{V} 7$ & 210 & 117 & 0,7 & 4,8 & 62 \\
\hline V5 $x$ V8 & 215 & 122 & 0,5 & 9,5 & 61 \\
\hline $\mathrm{V} 5 \times \mathrm{V} 9$ & 218 & 126 & 0,9 & 8,4 & 61 \\
\hline $\mathrm{V} 5 \times \mathrm{V} 10$ & 206 & 111 & 1,0 & 2,5 & 59 \\
\hline
\end{tabular}


Tabela 20. Médias conjuntas das variedades e híbridos para altura da planta (AP) e altura da espiga (AE), em $\mathrm{cm}$; percentagem de plantas acamadas $(\% A C)$; percentagem de plantas quebradas (\%PQ) e dias para florescimento masculino (DF), e coeficientes de variação experimental (CV). Experimentos 7 e 8. Anhembi. SP, 1998/99. (Continuação)

\begin{tabular}{|c|c|c|c|c|c|}
\hline Tratamentos & $A P$ & $A E$ & $\% A C$ & $\% P Q$ & $D F$ \\
\hline $\mathrm{V} 6 \times \mathrm{V7}$ & 214 & 121 & 1.1 & 18,3 & 64 \\
\hline $\mathrm{V} 6 \times \mathrm{V} 8$ & 207 & 118 & 0,7 & 7,5 & 60 \\
\hline$V 6 \times V 9$ & 222 & 133 & 0,8 & 4,4 & 65 \\
\hline $\mathrm{V} 6 \times \mathrm{V} 10$ & 196 & 107 & 1,2 & 9,3 & 59 \\
\hline V7 x V8 & 212 & 125 & 1,1 & 5,8 & 68 \\
\hline$V 7 \times \vee 9$ & 226 & 135 & 1,8 & 7,7 & 67 \\
\hline $\mathrm{V} 7 \times \mathrm{V} 10$ & 207 & 114 & 1,8 & 8,8 & 62 \\
\hline V8 x V9 & 223 & 134 & 0,0 & 3,1 & 65 \\
\hline $\mathrm{V} 8 \times \mathrm{V} 10$ & 207 & 115 & 0,5 & 8,2 & 61 \\
\hline $\mathrm{V} 9 \times \mathrm{V} 10$ & 208 & 118 & 0,8 & 4,4 & 63 \\
\hline Média geral & 205 & 115 & 0,9 & 7,0 & 61 \\
\hline Média Tr & 178 & 101 & 0.5 & 1,2 & 61 \\
\hline Média $T_{2}$ & 186 & 100 & 0.3 & 2.3 & 60 \\
\hline CV $(\%)$ & 5,7 & 8.0 & -- & -- & -- \\
\hline
\end{tabular}

$\mathrm{T}_{1}$ : Dina $766 ; \mathrm{T}_{2}$ : Mitla 9560. 
Tabela 21. Médias das variedades e híbridos para comprimento da espiga (CE) e diâmetro da espiga (DE), em cm; indice de espigas (IE); peso de grãos (PG), em tha; percentagem do peso de grãos em relação a testemunha 1 (\%T1) e percentagem do peso de grãos em relação a testemunha 2 (\%T2), e coeficientes de variação experimental (CV). Experimento 7, Anhembi, SP, 1998/99.

\begin{tabular}{|c|c|c|c|c|c|c|}
\hline Tratamentos & $\mathrm{CE}$ & $\mathrm{DE}$ & $\mathrm{IE}$ & $P G$ & $\% \mathrm{TT}$ & $\%$ T2 \\
\hline Taitinga (V1) & 14,70 & 4,37 & 1,03 & 3,49 & 91,3 & 72,2 \\
\hline Taiúba (V2) & 14,37 & 4.38 & 1,00 & 3,52 & 92,1 & 72,8 \\
\hline Cupurico DMR (V3) & 13,88 & 4,23 & 1,09 & 3,62 & 94,6 & 74,8 \\
\hline CMS 53 (V4) & 13,83 & 4,33 & 1,05 & 3,64 & 95,3 & 75,3 \\
\hline Suwan 2 (V5) & 14,03 & 4,10 & 0,96 & 3,00 & 78,5 & 62,1 \\
\hline Sikalq (V6) & 14,70 & 4,30 & 1,03 & 3,77 & 98,6 & 78,0 \\
\hline CMS 39 (V7) & 15,48 & 4,25 & 1,17 & 4,08 & 106,7 & 84,4 \\
\hline BR 105 (V8) & 14,42 & 4,20 & 1,00 & 3,51 & 91,8 & 72,6 \\
\hline AL 009 (V9) & 12,50 & 3,63 & 0,91 & 2,37 & 62,0 & 49,0 \\
\hline CMS 57NF (V10) & 14,52 & 4,52 & 0,95 & 3,44 & 90,0 & 71,2 \\
\hline V1 x V2 & 13,50 & 4,33 & 0,98 & 3,33 & 87,1 & 68,9 \\
\hline $\mathrm{V} 1 \times \mathrm{V} 3$ & 13,82 & 4,23 & 1,01 & 3,59 & 93,9 & 74,3 \\
\hline $\mathrm{V} 1 \times \mathrm{V} 4$ & 14,50 & 4,28 & 0,99 & 3,31 & 86,6 & 68,5 \\
\hline $\mathrm{V} 1 \times \mathrm{V} 5$ & 13,82 & 4,15 & 1,05 & 3,55 & 92,9 & 73,5 \\
\hline $\mathrm{V} 1 \times \mathrm{V} 6$ & 14,57 & 4,45 & 1,06 & 4,12 & 107,9 & 85,3 \\
\hline V1 x V7 & 15,28 & 4,25 & 1,09 & 4,08 & 106,8 & 84,4 \\
\hline $\mathrm{V} 1 \times \mathrm{V} 8$ & 14,38 & 4,22 & 0,98 & 3,50 & 91,6 & 72,4 \\
\hline $\mathrm{V} 1 \times \mathrm{V} 9$ & 14,52 & 4,20 & 1,09 & 3,93 & 102,9 & 81,4 \\
\hline $\mathrm{V} 1 \times \mathrm{V} 10$ & 13,38 & 4,17 & 0,99 & 2,80 & 73,3 & 57,9 \\
\hline V2 x V3 & 13,53 & 4,27 & 1,01 & 3,22 & 84,2 & 66,6 \\
\hline $\mathrm{V} 2 \times \mathrm{V} 4$ & 13,80 & 4,40 & 1,06 & 3,70 & 96,9 & 76,6 \\
\hline $\mathrm{V} 2 \times \mathrm{V} 5$ & 14,42 & 4,23 & 1,02 & 3,28 & 85,8 & 67,9 \\
\hline $\mathrm{V} 2 \times \mathrm{V} 6$ & 13,55 & 4,12 & 1,00 & 3,42 & 89,5 & 70,8 \\
\hline $\mathrm{V} 2 \times \mathrm{V} 7$ & 14,40 & 4,25 & 1,18 & 3,46 & 90,5 & 71,6 \\
\hline V2 $\times$ V8 & 14,55 & 4,33 & 1,07 & 3,84 & 100,4 & 79,4 \\
\hline V2 $\times$ V9 & 14,05 & 4,22 & 0,99 & 3,43 & 89,7 & 71,0 \\
\hline $\mathrm{V} 2 \times \mathrm{V} 10$ & 14,13 & 4,40 & 0,98 & 3,65 & 95,6 & 75,6 \\
\hline$\vee 3 \times \vee 4$ & 13,60 & 4,30 & 1,00 & 3,38 & 88,4 & 69,9 \\
\hline $\mathrm{V} 3 \times \mathrm{V} 5$ & 14,95 & 4,33 & 1,10 & 3,99 & 104,5 & 82,6 \\
\hline $\mathrm{V} 3 \times \mathrm{V} 6$ & 14,13 & 4,32 & 0,98 & 3,51 & 91,8 & 72,6 \\
\hline$\vee 3 \times \vee 7$ & 13,67 & 4,32 & 1,06 & 3,95 & 103,4 & 81,8 \\
\hline $\mathrm{V} 3 \times \mathrm{V} 8$ & 13,35 & 4,13 & 1,06 & 3,69 & 96,7 & 76,4 \\
\hline V3 x V9 & 14,37 & 4,07 & 1,06 & 3,42 & 89,5 & 70,8 \\
\hline V3 x V10 & 14,97 & 4,42 & 0,99 & 3,97 & 103,9 & 82,2 \\
\hline V4 x V5 & 14,30 & 4,30 & 1,04 & 3,43 & 89,7 & 70,9 \\
\hline $\mathrm{V} 4 \times \mathrm{V} 6$ & 14,30 & 4,42 & 1,06 & 3,85 & 100,7 & 79,6 \\
\hline$\vee 4 \times \vee 7$ & 13,87 & 4,22 & 1,02 & 3,36 & 87,9 & 69,5 \\
\hline V4 x V8 & 14,65 & 4,27 & 1,11 & 4,10 & 107,4 & 84,9 \\
\hline V4 × V9 & 13,65 & 4,23 & 1,01 & 3,10 & 81,1 & 64,1 \\
\hline V4 x V10 & 13,45 & 4,40 & 1,01 & 3,60 & 94,3 & 74,6 \\
\hline$\vee 5 \times \vee 6$ & 13,63 & 4,25 & 1,04 & 3,34 & 87,4 & 69,1 \\
\hline$\vee 5 \times \vee 7$ & 15,05 & 4,17 & 1,02 & 3,39 & 88,7 & 70,1 \\
\hline V5 $\times$ V8 & 15,02 & 4,28 & 1,08 & 3,69 & 96,4 & 76,2 \\
\hline V5 x V9 & 14,80 & 4,28 & 1,07 & 4,11 & 107,7 & 85,1 \\
\hline $\mathrm{V} 5 \times \mathrm{V} 10$ & 14,17 & 4,28 & 1,06 & 3,98 & 104,2 & 82,4 \\
\hline
\end{tabular}


Tabela 21. Médias das variedades e híbridos para comprimento da espiga (CE) e diâmetro da espiga (DE), em cm; indice de espigas (IE); peso de grãos (PG), em t/ha; percentagem do peso de grãos em relação a testemunha 1 (\%T1) e percentagem do peso de grãos em relação a testemunha 2 (\%T2), e coeficientes de variação experimental (CV). Experimento 7. Anhembi, SP, 1998/99. (Continuação)

\begin{tabular}{lcccccc}
\hline Tratamentos & CE & DE & IE & PG & $\% T 1$ & \%T2 \\
\hline V6 x V7 & 15,12 & 4,28 & 1,17 & 3,94 & 103,0 & 81,5 \\
V6 x V8 & 14,70 & 4,28 & 1,07 & 4,08 & 106,7 & 84,4 \\
V6 × V9 & 13,83 & 4,10 & 1,03 & 3,53 & 92,4 & 73,0 \\
V6 × V10 & 13,88 & 4,52 & 0,98 & 3,61 & 94,5 & 74,7 \\
V7 x V8 & 14,25 & 4,12 & 1,10 & 3,31 & 86,6 & 68,5 \\
V7 x V9 & 14,40 & 4,15 & 1,16 & 3,64 & 95,2 & 75,3 \\
V7 x V10 & 14,37 & 4,25 & 1,02 & 3,66 & 95,7 & 75,7 \\
V8 x V9 & 14,02 & 4,20 & 1,12 & 4,00 & 104,7 & 82,8 \\
V8 x V10 & 15,03 & 4,42 & 1,02 & 4,18 & 109,4 & 86,5 \\
V9 V10 & 13,78 & 4,32 & 1,06 & 3,54 & 92,6 & 73,2 \\
\hline Média geral & 14,21 & 4,26 & 1,04 & 3,60 & 94,2 & 74,5 \\
\hline Média T1 & 14,03 & 4,20 & 1,25 & 3,82 & -- & -- \\
Média T2 & 15,37 & 4,42 & 1,13 & 4,83 & -- & -- \\
\hline CV (\%) & 8,6 & 4,5 & 10,2 & 18,6 & -- & -- \\
\hline
\end{tabular}

$T_{1}$ : Dina $766 ; T_{2}$ : Mitla 9560. 
Tabela 22. Médias das variedades e híbridos para comprimento da espiga (CE) e diâmetro da espiga (DE), em cm; indice de espigas (IE); peso de grãos (PG), em tha; percentagem do peso de grãos em relação a testemunha 1 (\%T1) e percentagem do peso de grãos em relação a testemunha 2 (\%T2), e coeficientes de variação experimental (CV). Experimento 8, Anhembi, SP, 1998/99.

\begin{tabular}{|c|c|c|c|c|c|c|}
\hline Tratamentos & CE & $D E$ & $\mathrm{IE}$ & $P G$ & $\%$ T1 & $\%$ T2 \\
\hline Taitinga (V1) & 15,03 & 4,52 & 1,03 & 4,23 & 83,3 & 78,7 \\
\hline Taiúba (V2) & 13,93 & 4,39 & 0,98 & 4,04 & 79,6 & 75,2 \\
\hline Cupurico DMR (V3) & 14,93 & 4,25 & 0.99 & 3,90 & 76.8 & 72,5 \\
\hline CMS 53 (V4) & 13,73 & 4,50 & 1.09 & 4,18 & 82,5 & 77,9 \\
\hline Suwan 2 (V5) & 14,22 & 4,17 & 1.06 & 3,66 & 72,1 & 68,1 \\
\hline Sikalq (V6) & 15,08 & 4,20 & 1.00 & 4,02 & 79,2 & 74,8 \\
\hline CMS 39 (V7) & 16,27 & 4,32 & 1,14 & 4,78 & 94,2 & 88,9 \\
\hline BR 105 (V8) & 15,17 & 3,87 & 1,06 & 3,89 & 76,7 & 72,5 \\
\hline AL 009 (V9) & 13,00 & 3,87 & 0,93 & 3,20 & 63,0 & 59,5 \\
\hline CMS 57NF (V10) & 15,08 & 4,52 & 0,95 & 4,30 & 84,7 & 80,0 \\
\hline $\mathrm{V} 1 \times \mathrm{V} 2$ & 14,73 & 4,39 & 0,93 & 4,37 & 86,0 & 81,2 \\
\hline $\mathrm{V} 1 \times \mathrm{V} 3$ & 15,07 & 4,25 & 0,99 & 4,25 & 83,7 & 79,0 \\
\hline $\mathrm{V} 1 \times \mathrm{V} 4$ & 14,62 & 4,39 & 1.02 & 4,02 & 79,3 & 74,9 \\
\hline $\mathrm{V} 1 \times \mathrm{V} 5$ & 15,13 & 4,33 & 1.15 & 4,91 & 96,8 & 91,4 \\
\hline $\mathrm{V} 1 \times \mathrm{V} 6$ & 15,08 & 4,34 & 1.00 & 4,66 & 91,9 & 86,8 \\
\hline$\vee 1 \times \vee 7$ & 16,17 & 4,37 & 1,06 & 5,18 & 102,0 & 96,3 \\
\hline $\mathrm{V} 1 \times \mathrm{V} 8$ & 15,07 & 4,20 & 0,98 & 4,15 & 81,7 & 77,1 \\
\hline $\mathrm{V} 1 \times \mathrm{V} 9$ & 14,93 & 4,28 & 1,14 & 4,51 & 88,9 & 83,9 \\
\hline $\mathrm{V} 1 \times \mathrm{V} 10$ & 15,03 & 4,48 & 1,01 & 4,32 & 85,2 & 80,4 \\
\hline V2 x V3 & 14,02 & 4,39 & 0,99 & 4,16 & 82,0 & 77,4 \\
\hline $\mathrm{V} 2 \times \mathrm{V} 4$ & 14,13 & 4,67 & 1,01 & 4,49 & 88,4 & 83,5 \\
\hline $\mathrm{V} 2 \times \mathrm{V} 5$ & 14,90 & 4,27 & 1,01 & 3,91 & 77,1 & 72,8 \\
\hline $\mathrm{V} 2 \times \mathrm{V} 6$ & 15,27 & 4,30 & 1,04 & 4,67 & 92,1 & 87,0 \\
\hline$\vee 2 \times \vee 7$ & 14,92 & 4,42 & 1,18 & 4,67 & 92,1 & 87,0 \\
\hline $\mathrm{V} 2 \times \mathrm{V} 8$ & 15,40 & 4,32 & 1,07 & 4,84 & 95,5 & 90,1 \\
\hline $\mathrm{V} 2 \times \mathrm{V} 9$ & 14,68 & 4,35 & 1,05 & 4,61 & 90,8 & 85,8 \\
\hline $\mathrm{V} 2 \times \mathrm{V} 10$ & 14,72 & 4,35 & 1,07 & 4,64 & 91,4 & 86,3 \\
\hline V3 x V4 & 14,47 & 4,45 & 0,98 & 4,26 & 84,0 & 79,3 \\
\hline$\vee 3 \times \vee 5$ & 14,43 & 4,39 & 1,01 & 4,08 & 80,3 & 75,8 \\
\hline $\mathrm{V} 3 \times \mathrm{V} 6$ & 14,62 & 4,28 & 1,05 & 4,06 & 80,0 & 75,5 \\
\hline $\mathrm{V} 3 \times \mathrm{V} 7$ & 15,33 & 4,30 & 1,13 & 4,69 & 92,4 & 87,3 \\
\hline$V 3 \times \vee 8$ & 14,33 & 4,33 & 1.07 & 4,65 & 91,7 & 86,6 \\
\hline $\mathrm{V} 3 \times \mathrm{V} 9$ & 14,48 & 4,12 & 1,06 & 4,30 & 84,8 & 80,1 \\
\hline $\mathrm{V} 3 \times \mathrm{V} 10$ & 14,80 & 4,48 & 1,02 & 4,54 & 89,5 & 84,5 \\
\hline V4 x V5 & 15,75 & 4,47 & 1,11 & 4,53 & 89,3 & 84,3 \\
\hline$\vee 4 \times \vee 6$ & 14,13 & 4,42 & 0,97 & 4,17 & 82,1 & 77,5 \\
\hline $\mathrm{V} 4 \times \mathrm{V} 7$ & 14,95 & 4,42 & 1,03 & 4,45 & 87,7 & 82,8 \\
\hline$\vee 4 \times \vee 8$ & 15,17 & 4,35 & 1,08 & 4,82 & 95,0 & 89,7 \\
\hline$\vee 4 \times \vee 9$ & 14,42 & 4,37 & 1,00 & 4,40 & 86,8 & 81,9 \\
\hline V4 x V10 & 13,92 & 4,57 & 1,02 & 4,50 & 88,8 & 83,8 \\
\hline V5 x V6 & 14,73 & 4,33 & 1,00 & 4,15 & 81,7 & 77,2 \\
\hline$\vee 5 \times \vee 7$ & 16,25 & 4,32 & 1.11 & 4,74 & 93,4 & 88,2 \\
\hline V5 x V8 & 15,10 & 4,39 & 1,03 & 4,52 & 89,0 & 84,1 \\
\hline V5 $\times$ V9 & 14,40 & 4,22 & 1.11 & 4,56 & 89,8 & 84,8 \\
\hline V5 $x$ V10 & 15,22 & 4,45 & 1,06 & 4,71 & 92,9 & 87,7 \\
\hline
\end{tabular}


Tabela 22. Médias das variedades e hibridos para comprimento da espiga (CE) e diâmetro da espiga (DE), em cm; índice de espigas (IE); peso de grãos (PG), em t/ha; percentagem do peso de grãos em relação a testemunha 1 (\%T1) e percentagem do peso de grãos em relação a testemunha 2 (\%T2), e coeficientes de variação experimental (CV). Experimento 8, Anhembi, SP, 1998/99. (Continuação)

\begin{tabular}{|c|c|c|c|c|c|c|}
\hline Tratamentos & CE & $\mathrm{DE}$ & IE & $P G$ & \%T1 & $\% \mathrm{~T} 2$ \\
\hline V6 x V7 & 15,08 & 4,33 & 1,14 & 4,51 & 89,0 & 84,0 \\
\hline $\mathrm{V} 6 \times \mathrm{V} 8$ & 15,38 & 4,40 & 1,09 & 4,83 & 95,2 & 89,9 \\
\hline V6 x V9 & 14,82 & 4,27 & 1,06 & 4,50 & 88,8 & 83,8 \\
\hline$\vee 6 \times V 10$ & 14,32 & 4,43 & 0,98 & 4,35 & 85,7 & 80,9 \\
\hline V7 x V8 & 15,62 & 4,27 & 1,17 & 5,20 & 102,6 & 96,8 \\
\hline V7 x V9 & 15,50 & 4,17 & 1,18 & 4,91 & 96,9 & 91,4 \\
\hline$V 7 \times V 10$ & 15,15 & 4,40 & 1,03 & 4,45 & 87,8 & 82,9 \\
\hline V8 x V9 & 14,47 & 4,22 & 1,09 & 4,68 & 92,3 & 87,1 \\
\hline$V 8 \times V 10$ & 15,20 & 4,43 & 1,02 & 4,63 & 91,2 & 86,1 \\
\hline $\mathrm{V} 9 \times \mathrm{V} 10$ & 14,70 & 4,32 & 0,96 & 4,22 & 83,1 & 78,4 \\
\hline Média geral & 14,85 & 4,33 & 1,04 & 4,41 & 86,9 & 82,1 \\
\hline Média $T_{1}$ & 15,37 & 4,64 & 1,22 & 5.07 & - & - \\
\hline Média $T_{2}$ & 16,12 & 4,47 & 1,14 & 5,37 & - & - \\
\hline CV (\%) & 6,4 & 4,1 & 8,2 & 11,1 & - & - \\
\hline
\end{tabular}

$T_{1}$ : Dina $766 ; T_{2}:$ Mitla 9560. 
Tabela 23. Médias conjuntas das variedades e hibridos para comprimento da espiga (CE) e diâmetro da espiga (DE), em cm; índice de espigas (IE); peso de grãos (PG), em tha; percentagem do peso de grãos em relação a testemunha 1 (\%T1) e percentagem do peso de grãos em relação a testemunha 2 (\%T2), e coeficientes de variação experimental (CV). Experimentos 7 e 8. Anhembi, SP, 1998/99.

\begin{tabular}{|c|c|c|c|c|c|c|}
\hline Tratamentos & $\mathrm{CE}$ & DE & IE & PG & $\% \mathrm{~T} 1$ & $\%$ T2 \\
\hline Taitinga (V1) & 14,87 & 4,44 & 1,03 & 3,86 & 86,7 & 75,6 \\
\hline Taiúba (V2) & 14,15 & 4,38 & 0,99 & 3,78 & 84,9 & 74,1 \\
\hline Cupurico DMR (V3) & 14,41 & 4,24 & 1,05 & 3,76 & 84,3 & 73,6 \\
\hline CMS $53(\mathrm{~V} 4)$ & 13,78 & 4,42 & 1,07 & 3,91 & 87,9 & 76,7 \\
\hline Suwan 2 (V5) & 14,13 & 4,13 & 1,01 & 3,33 & 74,8 & 65,2 \\
\hline Sikalq (V6) & 14,89 & 4,25 & 1,01 & 3,89 & 87,4 & 76,3 \\
\hline CMS 39 (V7) & 15,88 & 4,28 & 1,16 & 4,43 & 99,5 & 86,8 \\
\hline BR 105 (V8) & 14,79 & 4,03 & 1,03 & 3,70 & 83,1 & 72,5 \\
\hline AL 009 (V9) & 12,75 & 3,75 & 0,92 & 2,78 & 62,5 & 54,5 \\
\hline CMS 57NF (V10) & 14,80 & 4,52 & 0,95 & 3,87 & 86,9 & 75,8 \\
\hline $\mathrm{V} 1 \times \mathrm{V} 2$ & 14,12 & 4,36 & 0,95 & 3,85 & 86,4 & 75,4 \\
\hline $\mathrm{V} 1 \times \mathrm{V} 3$ & 14,44 & 4,24 & 1,00 & 3,92 & 88,0 & 76,8 \\
\hline $\mathrm{V} 1 \times \mathrm{V} 4$ & 14,56 & 4,33 & 1,00 & 3,67 & 82,4 & 71,9 \\
\hline $\mathrm{V} 1 \times \mathrm{V} 5$ & 14,48 & 4,24 & 1,10 & 4,23 & 95,0 & 82,9 \\
\hline $\mathrm{V} 1 \times \mathrm{V} 6$ & 14,83 & 4,39 & 1,03 & 4,39 & 98,7 & 86,1 \\
\hline $\mathrm{V} 1 \times \mathrm{V} 7$ & 15,73 & 4,31 & 1,08 & 4,63 & 103,9 & 90,7 \\
\hline V1 x V8 & 14,73 & 4,21 & 0,98 & 3,82 & 85,9 & 74,9 \\
\hline V1 x V9 & 14,73 & 4,24 & 1,12 & 4,22 & 94,8 & 82,7 \\
\hline $\mathrm{V} 1 \times \mathrm{V} 10$ & 14,21 & 4,32 & 1,00 & 3,56 & 80,0 & 69,8 \\
\hline V2 x V3 & 13,78 & 4,32 & 1,00 & 3,69 & 82,8 & 72,3 \\
\hline $\mathrm{V} 2 \times \mathrm{V} 4$ & 13,97 & 4,53 & 1,04 & 4,09 & 92,0 & 80,2 \\
\hline $\mathrm{V} 2 \times \mathrm{V} 5$ & 14,66 & 4,25 & 1,02 & 3,60 & 80,7 & 70,4 \\
\hline $\mathrm{V} 2 \times \mathrm{V} 6$ & 14,41 & 4,21 & 1,02 & 4,05 & 90,9 & 79,3 \\
\hline V2 x V7 & 14,66 & 4,33 & 1,18 & 4,07 & 91,3 & 79,7 \\
\hline $\mathrm{V} 2 \times \mathrm{V} 8$ & 14,98 & 4,32 & 1,07 & 4,34 & 97,5 & 85,0 \\
\hline V2 x V9 & 14,37 & 4,28 & 1,02 & 4,02 & 90,3 & 78,8 \\
\hline $\mathrm{V} 2 \times \mathrm{V} 10$ & 14,43 & 4,37 & 1,03 & 4,15 & 93,1 & 81,2 \\
\hline V3 x V4 & 14,03 & 4,37 & 0,99 & 3,82 & 85,8 & 74,9 \\
\hline V3 $\times$ V5 & 14,69 & 4,36 & 1,06 & 4,03 & 90,6 & 79,0 \\
\hline V3 $\times$ V6 & 14,38 & 4,30 & 1,02 & 3,78 & 85,0 & 74,2 \\
\hline V3 $x$ V7 & 14,50 & 4,31 & 1,10 & 4,32 & 97,1 & 84,7 \\
\hline V3 $\times$ V8 & 13,84 & 4,23 & 1,06 & 4,17 & 93,8 & 81,8 \\
\hline V3 x V9 & 14,43 & 4,09 & 1,06 & 3,86 & 86,7 & 75,7 \\
\hline $\mathrm{V} 3 \times \mathrm{V} 10$ & 14,88 & 4,45 & 1,00 & 4,26 & 95,6 & 83,4 \\
\hline V4 x V5 & 15,03 & 4,38 & 1,08 & 3,98 & 89,4 & 78,0 \\
\hline $\mathrm{V} 4 \times \mathrm{V} 6$ & 14,22 & 4,42 & 1,01 & 4,01 & 90,0 & 78,5 \\
\hline V4 x V7 & 14,41 & 4,32 & 1,03 & 3,90 & 87,7 & 76,5 \\
\hline V4 x V8 & 14,91 & 4,31 & 1,10 & 4,46 & 100,2 & 87,4 \\
\hline V4 x V9 & 14,03 & 4,30 & 1,00 & 3,75 & 84,2 & 73,5 \\
\hline $\mathrm{V} 4 \times \mathrm{V} 10$ & 13,68 & 4,48 & 1,02 & 4,05 & 91,1 & 79,4 \\
\hline V5 x V6 & 14,18 & 4,29 & 1,02 & 3,74 & 84,1 & 73,4 \\
\hline $\mathrm{V} 5 \times \mathrm{V} 7$ & 15,65 & 4,24 & 1,07 & 4,07 & 91,3 & 79,7 \\
\hline V5 x V8 & 15,06 & 4,33 & 1,06 & 4,10 & 92,1 & 80,4 \\
\hline V5 x V9 & 14,60 & 4,25 & 1,09 & 4,33 & 97,4 & 84,9 \\
\hline V5 x V10 & 14,69 & 4,37 & 1,06 & 4,35 & 97,6 & 85,2 \\
\hline
\end{tabular}


Tabela 23. Médias conjuntas das variedades e híbridos para comprimento da espiga (CE) e diâmetro da espiga (DE), em cm; índice de espigas (IE); peso de grãos (PG), em t/ha; percentagem do peso de grãos em relação a testemunha 1 (\%T1) e percentagem do peso de grãos em relação a testemunha 2 (\%T2), e coeficientes de variação experimental (CV). Experimentos 7 e 8, Anhembi, SP, 1998/99. (Continuação)

\begin{tabular}{|c|c|c|c|c|c|c|}
\hline Tratamentos & $\mathrm{CE}$ & $\mathrm{DE}$ & $\mathrm{IE}$ & $P G$ & $\%$ T1 & $\%$ T2 \\
\hline $\mathrm{V} 6 \times \mathrm{V} 7$ & 15,10 & 4,31 & 1,16 & 4,23 & 94,9 & 82,8 \\
\hline V6 $\times$ V8 & 15,04 & 4,34 & 1,08 & 4,45 & 100,0 & 87,3 \\
\hline V6 $\times$ V9 & 14,33 & 4,18 & 1,05 & 4,02 & 90,2 & 78,7 \\
\hline$V 6 \times V 10$ & 14,10 & 4,47 & 0,98 & 3,98 & 89,4 & 78,0 \\
\hline V7 x V8 & 14,93 & 4,19 & 1,14 & 4,26 & 95,6 & 83,4 \\
\hline$\vee 7 \times \vee 9$ & 14,95 & 4,16 & 1,17 & 4,28 & 96,0 & 83,8 \\
\hline $\mathrm{V} 7 \times \vee 10$ & 14,76 & 4,32 & 1,03 & 4,06 & 91,1 & 79,5 \\
\hline V8 x V9 & 14,24 & 4,21 & 1,11 & 4,34 & 97,5 & 85,1 \\
\hline$V 8 \times \vee 10$ & 15,12 & 4,43 & 1,02 & 4,40 & 98,9 & 86,3 \\
\hline $\mathrm{V} 9 \times \mathrm{V} 10$ & 14,24 & 4,32 & 1,01 & 3,88 & 87,1 & 76,0 \\
\hline Média geral & 14,53 & 4,29 & 1,04 & 4,01 & 90.0 & 78,6 \\
\hline Média $T_{1}$ & 14,70 & 4,42 & 1,23 & 4,45 & -- & - \\
\hline Média $T_{2}$ & 15,75 & 4,44 & 1,13 & 5,10 & - & -- \\
\hline CV $(\%)$ & 7,5 & 4,4 & 9,2 & 15,1 & $\cdots$ & - \\
\hline
\end{tabular}

$T_{1}$ : Dina $766 ; T_{2}:$ Mitla 9560. 
Tabela 24. Resumo das análises de variância conjuntas de cruzamento dialélico para altura da planta (AP) e altura da espiga (AE), em cm; comprimento da espiga (CE) e diâmetro da espiga (DE) em cm; e peso de grãos (PG), em t/ha. Experimentos 7 e 8. Anhembi, SP, 1998/99.

\begin{tabular}{|c|c|c|c|c|c|c|}
\hline \multirow[t]{2}{*}{ Fontes de variação } & \multirow[t]{2}{*}{ GL } & \multicolumn{5}{|c|}{ Quadrados médios } \\
\hline & & $A P$ & $A E$ & CE & $D E$ & $P G\left(10^{3}\right)$ \\
\hline Experimentos (Exp.) & 1 & $12787,236^{\star \star}$ & $8325,900^{\star \star}$ & $56.013^{\star \star}$ & $0,782^{\star \star}$ & $18384,552^{\star \star}$ \\
\hline Tratamentos (Trat.) & 54 & $205,334^{\star \star}$ & $187,062^{\star \star}$ & $2,790^{\star \star}$ & $0,157^{\star \star}$ & $199,071^{\star \star}$ \\
\hline Variedades (Var.) & 9 & $847,418^{\star \star}$ & $955,138^{\star \star}$ & $8,877^{\star \star}$ & $0,613^{\star \star}$ & $280,981^{\star \star}$ \\
\hline Heteroses (Het.) & 45 & $76,917^{\star \star}$ & $33,446^{\star \star}$ & $1,572^{\star}$ & $0,066^{\star \star}$ & $182,692^{\star \star}$ \\
\hline Het. média (hm) & 1 & $476,182^{\star \star}$ & $203,008^{\star \star}$ & $1,038^{\text {ns }}$ & $0,364^{\star \star}$ & $1873,147^{\star \star}$ \\
\hline Het. variedades (hv) & 9 & $63,695^{\star \star}$ & $38,908^{\star \star}$ & $2,903^{\star \star}$ & $0,154^{\star \star}$ & $265,085^{\star \star}$ \\
\hline Het. especifica (he) & 35 & $68,909^{\star \star}$ & $27,198^{\star \star}$ & $1,245^{\mathrm{ns}}$ & $0,035^{\text {ns }}$ & $113,202^{\star \star}$ \\
\hline CGC & 9 & $564,108^{\star \star}$ & $749,580^{\star \star}$ & $4,925^{\star \star}$ & $0,250^{\star \star}$ & $180,861^{\star \star}$ \\
\hline Trat. X Exp. & 54 & $40,106^{\star \star}$ & $17,307^{n S}$ & $0,700^{\text {ns }}$ & $0,029^{\text {nS }}$ & $56,602^{n s}$ \\
\hline Var. X Exp. & 9 & $20,507^{\mathrm{ns}}$ & $34,242^{\star}$ & $0,444^{\mathrm{ns}}$ & $0,045^{\text {ns }}$ & $77,404^{\mathrm{ns}}$ \\
\hline Het. X Exp. & 45 & $44,026^{\star \star}$ & $13,920^{\text {ns }}$ & $0,751^{\mathrm{ns}}$ & $0,026^{\mathrm{ns}}$ & $52,441^{\mathrm{ns}}$ \\
\hline $\mathrm{hm} \times$ Exp. & 1 & $16,913^{\mathrm{ns}}$ & $41,311^{\mathrm{ns}}$ & $1,717^{\mathrm{ns}}$ & $0,069^{\text {ns }}$ & $356,823^{\star}$ \\
\hline hv $\times$ Exp. & 9 & $38,073^{\text {ns }}$ & $14,093^{\text {ns }}$ & $0,497^{\mathrm{ns}}$ & $0,037^{n s}$ & $22,811^{\mathrm{ns}}$ \\
\hline he X Exp. & 35 & $46,332^{\star \star}$ & $13,093^{n s}$ & $0,789^{\mathrm{ns}}$ & $0,022^{n s}$ & $51,373^{\mathrm{ns}}$ \\
\hline CGC X Exp. & 9 & $36,641^{\text {nS }}$ & $29,691^{\star}$ & $0,462^{n \mathrm{~s}}$ & $0,020^{\text {ns }}$ & $76,254^{\text {ns }}$ \\
\hline Resíduo médio $^{\top}$ & 540 & 22,123 & 13,883 & 1,012 & 0,029 & 57,872 \\
\hline
\end{tabular}

Média dos quadrados médios em análises individuais. em nível de média de repetições.

$\left(10^{3}\right)$ : Quadrados médios multiplicados por $10^{3}$.

ns, ${ }^{\star} \mathrm{e}^{\star \star}$ : não significativos, significativos ao nivel de $5 \%$ e $1 \%$ de probabilidade, respectivamente. 
Tabela 25. Estimativas conjuntas dos efeitos de variedades $\left(V_{i}\right)$, heterose de variedades $\left(h_{1}\right)$ e capacidade geral de combinação $\left(\mathrm{g}_{i}\right)$, para altura da planta $(A P)$, altura da espiga $(A E)$, comprimento da espiga (CE) e diâmetro da espiga $(D E)$, em $\mathrm{cm}$; e peso de grãos (PG), em tha. Experimentos 7 e 8, Anhembi, SP. 1998/99.

\begin{tabular}{lccccc}
\multicolumn{7}{c}{ Efeitos de variedades $\left(v_{i}\right)$} \\
\hline Variedades & $\mathrm{AP}$ & $\mathrm{AE}$ & $\mathrm{CE}$ & $\mathrm{DE}$ & $\mathrm{PG}$ \\
\hline Taitinga & 3,85 & $-3,30$ & 0,42 & 0,19 & 0,128 \\
Taiúba & $-1,65$ & $-1,80$ & $-0,29$ & 0,14 & 0,048 \\
Cupurico DMR & $-8,15$ & $-5,80$ & $-0,03$ & $-0,01$ & 0,028 \\
CMS 53 & $-6,65$ & $-7,30$ & $-0,66$ & 0,17 & 0,178 \\
Suwan 2 & 2,85 & 1,20 & $-0,31$ & $-0,11$ & $-0,402$ \\
Sikalq & $-7,15$ & $-6,30$ & 0,44 & 0,01 & 0,169 \\
CMS 39 & 21,85 & 18,20 & 1,43 & 0,03 & 0,698 \\
BR 105 & 6,85 & 8,70 & 0,34 & $-0,21$ & $-0,032$ \\
AL 009 & 13,85 & 14,70 & $-1,69$ & $-0,48$ & $-0,947$ \\
CMS 57NF & $-25,65$ & $-18,30$ & 0,35 & 0,27 & 0,138 \\
\hline
\end{tabular}

Efeitos de heterose de variedades $\left(h_{1}\right)$

\begin{tabular}{lccccc}
\hline Variedades & $\mathrm{AP}$ & $\mathrm{AE}$ & $\mathrm{CE}$ & $\mathrm{DE}$ & $\mathrm{PG}$ \\
\hline Taitinga & $-3,16$ & $-0,96$ & $-0,11$ & $-0,11$ & $-0,106$ \\
Taiúba & $-2,66$ & $-1,46$ & $-0,06$ & $-0,04$ & $-0,122$ \\
Cupurico DMR & 1,40 & $-1,21$ & $-0,23$ & $-0,01$ & $-0,111$ \\
CMS 53 & $-4,60$ & $-3,15$ & 0,05 & $-0,01$ & $-0,201$ \\
Suwan 2 & $-1,60$ & $-2,90$ & 0,41 & 0,04 & 0,176 \\
Sikalq & 3,15 & 1,66 & $-0,27$ & 0,01 & $-0,079$ \\
CMS 39 & $-2,97$ & $-1,08$ & $-0,25$ & $-0,06$ & $-0,203$ \\
BR 105 & 1,65 & 2,10 & 0,05 & 0,07 & 0,231 \\
AL 009 & 2,90 & 5,72 & 0,70 & 0,15 & 0,481 \\
CMS 57NF & 5,90 & 1,28 & $-0,29$ & $-0,04$ & $-0,063$ \\
\hline - & 5,39 & 3,52 & 0,11 & 0,06 & 0,338 \\
\hline
\end{tabular}

Efeitos de capacidade geral de combinação $\left(g_{i}\right)$

\begin{tabular}{lccccc}
\hline Variedades & $\mathrm{AP}$ & $\mathrm{AE}$ & $\mathrm{CE}$ & $\mathrm{DE}$ & $\mathrm{PG}$ \\
\hline Taitinga & $-1,23$ & $-2,61$ & 0,09 & $-0,02$ & $-0,042$ \\
Taiúba & $-3,48$ & $-2,35$ & $-0,21$ & 0,02 & $-0,098$ \\
Cupurico DMR & $-2,67$ & $-4,11$ & $-0,26$ & $-0,01$ & $-0,097$ \\
CMS 53 & $-7,92$ & $-6,80$ & $-0,28$ & 0,08 & $-0,112$ \\
Suwan 2 & $-0,17$ & $-2,30$ & 0,25 & $-0,01$ & $-0,024$ \\
Sikalq & $-0,42$ & $-1,48$ & $-0,06$ & 0,01 & $-0,002$ \\
CMS 39 & 7,95 & 8,01 & 0,44 & $-0,04$ & 0,145 \\
BR 105 & 5,07 & 6,45 & 0,29 & $-0,03$ & 0,215 \\
AL 009 & 9,82 & 13,07 & $-0,14$ & $-0,09$ & 0,007 \\
CMS 57NF & $-6,92$ & $-7,86$ & $-0,12$ & 0,09 & 0,005 \\
\hline
\end{tabular}


Tabela 26. Estimativas conjuntas dos efeitos de heterose específica $\left(s_{i i}\right)$ para altura da planta (AP) e altura da espiga (AE), em cm; e peso de grãos (PG), em t/ha. Experimentos 7 e 8 . Anhembi, SP, 1998/99.

\begin{tabular}{|c|c|c|c|c|c|c|c|}
\hline Hibridos & $A P$ & $A E$ & $P G$ & Híbridos & AP & $A E$ & $P G$ \\
\hline $\mathrm{V} 1 \times \mathrm{V} 2$ & 2,68 & 2,65 & $-0,079$ & V4 $\times$ V5 & 0,05 & 3.27 & 0,046 \\
\hline$V 1 \times V 3$ & $-0,63$ & $-0,59$ & $-0,010$ & $\vee 4 \times \vee 6$ & 8,80 & 4,46 & 0,049 \\
\hline$V 1 \times V 4$ & $-4,38$ & $-2,40$ & $-0,250$ & $\mathrm{~V} 4 \times \vee 7$ & 3,43 & 1,46 & $-0,198$ \\
\hline $\mathrm{V} 1 \times \mathrm{V} 5$ & 0,86 & 3,59 & 0,227 & V4 x V8 & 2,80 & 3,02 & 0,286 \\
\hline$V 1 \times V 6$ & $-1,88$ & $-0,72$ & 0,360 & V4 $\times$ V9 & $-9,44$ & $-4,59$ & $-0,215$ \\
\hline $\mathrm{V} 1 \times \mathrm{V} 7$ & 10,74 & 6,77 & 0,457 & $\mathrm{~V} 4 \times \mathrm{V} 10$ & 1,80 & 0,84 & 0,086 \\
\hline $\mathrm{V} 1 \times \mathrm{V} 8$ & $-1,88$ & $-5,65$ & $-0,417$ & V5 $\times$ V6 & 0,55 & $-5,53$ & $-0,302$ \\
\hline $\mathrm{V} 1 \times \mathrm{V} 9$ & 4,86 & 1,71 & 0,184 & $\vee 5 \times \vee 7$ & $-7,81$ & $-4,03$ & $-0,125$ \\
\hline $\mathrm{V} 1 \times \mathrm{V} 10$ & $-10,38$ & $-5,34$ & $-0,472$ & $\mathrm{~V} 5 \times \mathrm{V} 8$ & 4,05 & 2,52 & $-0,155$ \\
\hline $\mathrm{V} 2 \times \mathrm{V} 3$ & $-4,38$ & $-3,34$ & $-0,184$ & $\mathrm{~V} 5 \times \mathrm{V} 9$ & $-3,69$ & $-0,09$ & 0,281 \\
\hline$V 2 \times V 4$ & 0,36 & $-1,15$ & 0,235 & $\mathrm{~V} 5 \times \mathrm{V} 10$ & 8,55 & 4,84 & 0,294 \\
\hline $\mathrm{V} 2 \times \mathrm{V} 5$ & $-2,38$ & $-2,65$ & $-0,352$ & $V 6 \times \vee 7$ & $-2,06$ & $-1,34$ & 0,007 \\
\hline $\mathrm{V} 2 \times \mathrm{V} 6$ & $-4,13$ & $-1,97$ & 0,071 & $V 6 \times V 8$ & $-7,19$ & $-2,28$ & 0,167 \\
\hline $\mathrm{V} 2 \times \mathrm{V} 7$ & $-0,50$ & 0,52 & $-0,052$ & $\mathrm{~V} 6 \times \mathrm{V} 9$ & 5,55 & 5,59 & $-0,065$ \\
\hline$V 2 \times V 8$ & 0,86 & 2,09 & 0,152 & $\mathrm{~V} 6 \times \mathrm{V} 10$ & $-3,19$ & 1,02 & $-0,097$ \\
\hline $\mathrm{V} 2 \times \mathrm{V} 9$ & 11,61 & 3,96 & 0,040 & V7 x V8 & $-7,06$ & $-4,78$ & $-0,175$ \\
\hline $\mathrm{V} 2 \times \mathrm{V} 10$ & $-4,13$ & $-0,09$ & 0,167 & $\vee 7 \times \vee 9$ & 1,18 & $-1,90$ & 0,051 \\
\hline $\mathrm{V} 3 \times \mathrm{V} 4$ & $-3,44$ & $-4,90$ & $-0,040$ & $\mathrm{~V} 7 \times \mathrm{V} 10$ & $-0,56$ & $-1,47$ & $-0,165$ \\
\hline $\mathrm{V} 3 \times \mathrm{V} 5$ & $-0,19$ & $-1,90$ & 0,086 & V8 $\times$ V9 & 1,55 & $-0,84$ & 0,046 \\
\hline$V 3 \times V 6$ & 3,55 & 0,77 & $-0,190$ & $\mathrm{~V} 8 \times \mathrm{V} 10$ & 1,80 & 1,09 & 0,114 \\
\hline V3 $\times$ V7 & 2,68 & 4,77 & 0,201 & $\mathrm{~V} 9 \times \mathrm{V} 10$ & $-1,42$ & $-2,53$ & $-0,203$ \\
\hline$\sqrt{ } 3 \times \sqrt{ } 8$ & 5,05 & 4,84 & $-0,018$ & -- & -. & -- & -- \\
\hline $\mathrm{V} 3 \times \mathrm{V} 9$ & $-10,19$ & $-1,28$ & $-0,120$ & - & -- & - & - \\
\hline$V 3 \times V 10$ & 7,55 & 1,65 & 0,276 & -. & -- & -. & -- \\
\hline
\end{tabular}

Taitinga (V1), Taiúba (V2), Cupurico DMR (V3), C
(V7), BR 105 (V8), AL 009 (V9), CMS 57NF (V10) 
Tabela 27. Estimativas conjuntas de heterose (h) e percentual de heterose (\%h) em relação a média das variedades progenitoras; e estimativas conjuntas de heterose $\left(h_{s}\right)$ e percentual de heterose $\left(\% h_{s}\right)$ em relação a variedade progenitora de maior média, para peso de grãos (PG), em tha. Experimentos 7 e 8, Anhembi, SP, 1998/99.

\begin{tabular}{|c|c|c|c|c|}
\hline Hibridos & $\mathrm{h}$ & $\% h$ & $h_{\mathrm{s}}$ & $\% h_{s}$ \\
\hline $\mathrm{V} 1 \times \mathrm{V} 2$ & 0,03 & 0.2 & $-0,03$ & $-1,2$ \\
\hline$V_{1} \times V_{3}$ & 0,11 & 2,7 & $-0,01$ & $-0,2$ \\
\hline $\mathrm{V} 1 \times \mathrm{V} 4$ & $-0,22$ & $-5,7$ & $-0,27$ & $-6,9$ \\
\hline $\mathrm{V} 1 \times \mathrm{V} 5$ & 0,63 & 16,9 & 0,37 & 8,9 \\
\hline $\mathrm{V} 1 \times \mathrm{V} 6$ & 0,52 & 13,3 & 0,39 & 9,7 \\
\hline $\mathrm{V} 1 \times \mathrm{V} 7$ & 0,48 & 11,3 & 0,20 & 4,1 \\
\hline $\mathrm{V} 1 \times \mathrm{V} 8$ & 0,04 & 0,9 & $-0,05$ & $-1,2$ \\
\hline $\mathrm{V} 1 \times \mathrm{V} 9$ & 0,90 & 27,8 & 0,36 & 9,6 \\
\hline $\mathrm{V} 1 \times \mathrm{V} 10$ & $-0,31$ & $-8,9$ & $-0,33$ & $-9,6$ \\
\hline V2 x V3 & $-0,08$ & $-2,5$ & $-0,14$ & $-4,3$ \\
\hline $\mathrm{V} 2 \times \mathrm{V} 4$ & 0,25 & 6,1 & 0,25 & 6,3 \\
\hline $\mathrm{V} 2 \times \mathrm{V} 5$ & 0,04 & 0,9 & $-0,19$ & $-5,1$ \\
\hline $\mathrm{V} 2 \times \mathrm{V} 6$ & 0,21 & 4,8 & 0,14 & 3,1 \\
\hline $\mathrm{V} 2 \times \mathrm{V} 7$ & $-0,04$ & $-1,5$ & $-0,36$ & $-8,7$ \\
\hline V2 x V8 & 0,59 & 15,4 & 0,55 & 14,2 \\
\hline $\mathrm{V} 2 \times \mathrm{V} 9$ & 0,74 & 21,8 & 0,23 & 5,6 \\
\hline $\mathrm{V} 2 \times \mathrm{V} 10$ & 0,32 & 7,9 & 0,23 & 5,6 \\
\hline V3 x V4 & $-0,02$ & $-0,7$ & $-0,09$ & $-2,6$ \\
\hline $\mathrm{V} 3 \times \mathrm{V} 5$ & 0,49 & 14,1 & 0,27 & 7,3 \\
\hline $\mathrm{V} 3 \times \mathrm{V} 6$ & $-0,04$ & $-1,2$ & $-0,11$ & $-2,9$ \\
\hline $\mathrm{V} 3 \times \mathrm{V} 7$ & 0,23 & 5,3 & $-0,11$ & $-2,5$ \\
\hline V3 $x$ V8 & 0,44 & 11,4 & 0,41 & 10,6 \\
\hline $\mathrm{V} 3 \times \mathrm{V} 9$ & 0,59 & 17,7 & 0,10 & 2,4 \\
\hline $\mathrm{V} 3 \times \mathrm{V} 10$ & 0,44 & 11,5 & 0,30 & 7,6 \\
\hline V4 x V5 & 0,36 & 9,4 & 0,07 & 1,3 \\
\hline $\mathrm{V} 4 \times \mathrm{V} 6$ & 0,10 & 2,7 & 0,03 & 0,8 \\
\hline V4 $\times$ V7 & $-0,26$ & $-6,8$ & $-0,53$ & $-12,2$ \\
\hline V4 x V8 & 0,65 & 17,0 & 0,55 & 14,0 \\
\hline V4 x V9 & 0,40 & 11,2 & $-0,16$ & $-4,7$ \\
\hline $\mathrm{V} 4 \times \mathrm{V} 10$ & 0,16 & 3,9 & 0,08 & 1,8 \\
\hline V5 x V6 & 0,13 & 3,3 & $-0,15$ & $-4,1$ \\
\hline $\mathrm{V} 5 \times \mathrm{V} 7$ & 0,19 & 4,0 & $-0,37$ & $-8,8$ \\
\hline $\mathrm{V} 5 \times \mathrm{V} 8$ & 0,58 & 16,3 & 0,40 & 10,4 \\
\hline $\mathrm{V} 5 \times \mathrm{V} 9$ & 1,28 & 43,0 & 0,89 & 27,1 \\
\hline V5 x V10 & 0,74 & 20,9 & 0,47 & 12,4 \\
\hline V6 x V7 & 0,06 & 1,4 & $-0,20$ & $-4,5$ \\
\hline V6 $\times$ V8 & 0,65 & 16,9 & 0,56 & 14,1 \\
\hline $\mathrm{V} 6 \times \mathrm{V} 9$ & 0,68 & 19,9 & 0,12 & 2,8 \\
\hline $\mathrm{V} 6 \times \mathrm{V} 10$ & 0,09 & 2,2 & $-0,06$ & $-1,5$ \\
\hline V7 x V8 & 0,19 & 3,5 & $-0,17$ & $-5,0$ \\
\hline V7 $\times$ V9 & 0,67 & 18,0 & $-0,16$ & $-4,0$ \\
\hline $\mathrm{V} 7 \times \mathrm{V} 10$ & $-0,10$ & $-2,3$ & $-0,37$ & $-8,5$ \\
\hline V8 x V9 & 1,10 & 34,0 & 0,64 & 17,0 \\
\hline $\mathrm{V} 8 \times \mathrm{V} 10$ & 0,61 & 16,4 & 0,49 & 13,1 \\
\hline $\mathrm{V} 9 \times \mathrm{V} 10$ & 0,55 & 17,0 & 0,00 & 0,3 \\
\hline
\end{tabular}

(V7), BR 105 (V8), AL 009 (V9), CMS 57NF (V10). 
Tabela 28. Estimativas conjuntas do índice $l$, de vaniedades para o peso de grãos (PG), em t/ha, em compostos de tamanho $k=2, k=3, k=4$ e $k=5$, respectivamente. Experimentos $7 \mathrm{e}$ 8, Anhembi, SP. 1998/99.

\begin{tabular}{lcccc}
\hline Variedades & $\mathrm{k}=2$ & $\mathrm{k}=3$ & $\mathrm{k}=4$ & $\mathrm{k}=5$ \\
\hline Taitinga (V1) & 0,011 & $-0,004$ & $-0,008$ & $-0,008$ \\
Taiüba (V2) & $-0,037$ & $-0,038$ & $-0,034$ & $-0,029$ \\
Cupurico DMR (V3) & $-0,042$ & $-0,040$ & $-0,035$ & $-0,030$ \\
CMS 53 (V4) & $-0,012$ & $-0,030$ & $-0,031$ & $-0,029$ \\
Suwan 2 (V5) & $-0,113$ & $-0,056$ & $-0,035$ & $-0,024$ \\
Sikalq (V6) & 0,045 & 0,021 & 0,013 & 0,009 \\
CMS 39 (V7) & 0,248 & 0,142 & 0,098 & 0,075 \\
BR 105 (V8) & 0,100 & 0,092 & 0,079 & 0,068 \\
AL 009 (V9) & $-0,233$ & $-0,102$ & $-0,056$ & $-0,035$ \\
CMS 57NF (V10) & 0,038 & 0,018 & 0,011 & 0,007 \\
\hline
\end{tabular}

$I_{i}=w_{1} v_{i}+w_{2} h_{i}$, com $w_{1}=1 / k$ e $w_{2}=2(k-1) / k^{2}$ 
Tabela 29. Médias conjuntas preditas para os compostos de tamanho $k=2, k=3, k=4$ e $k=5$. respectivamente, para altura da planta (AP) e altura da espiga (AE) em cm; percentagem de plantas acamadas (\%AC); percentagem de plantas quebradas (\%PQ): dias para florescimento masculino (DF); comprimento da espiga (CE) $e$ diâmetro da espiga (DE), em cm; índice de espigas (IE) e peso de grãos (PG), em t/ha; a partir das cinco variedades de maior $I_{1}$. Experimentos 7 e 8 , Anhembi, SP, 1998/99.

\begin{tabular}{|c|c|c|c|c|c|c|c|c|c|}
\hline Composto & AP & $A E$ & $\% A C$ & $\% P Q$ & DF & CE & $\mathrm{DE}$ & IE & $P G$ \\
\hline \multicolumn{10}{|l|}{$\mathrm{K}=2$} \\
\hline C1,6 & 201 & 109 & 1,2 & 8,6 & 59 & 14,85 & 4,37 & 1,03 & 4.13 \\
\hline C1,7 & 219 & 124 & 0,9 & 6,3 & 64 & 15,54 & 4,33 & 1,09 & 4.39 \\
\hline C1,8 & 207 & 114 & 1,5 & 7,5 & 62 & 14,78 & 4,22 & 1,01 & 3.80 \\
\hline C1,10 & 189 & 101 & 0,8 & 3,8 & 61 & 14,52 & 4,40 & 1,00 & 3.71 \\
\hline C6,7 & 211 & 120 & 1,0 & 13,6 & 64 & 15,24 & 4,28 & 1,12 & 4.20 \\
\hline C6,8 & 204 & 116 & 0,9 & 9,1 & 61 & 14,94 & 4,24 & 1,05 & 4.12 \\
\hline C6,10 & 191 & 104 & 1,0 & 7,6 & 59 & 14,47 & 4,22 & 0,98 & 3.93 \\
\hline C7,8 & 214 & 125 & 1,2 & 8,1 & 67 & 15,13 & 4,17 & 1,12 & 4.16 \\
\hline$C 7,10$ & 203 & 113 & 1,3 & 7,2 & 63 & 15,04 & 4,36 & 1,04 & 4.11 \\
\hline$C 8,10$ & 200 & 111 & 0,8 & 7,8 & 62 & 14,95 & 4,35 & 1,01 & 4.09 \\
\hline Média & 204 & 117 & 1,1 & 8,0 & 62 & 14,94 & 4,31 & 1,04 & 4.06 \\
\hline \multicolumn{10}{|l|}{$\mathrm{K}=3$} \\
\hline $\mathrm{C}_{1,6,7}$ & 212 & 118 & 1,0 & 10,1 & 62 & 15,21 & 4,33 & 1,08 & 4.30 \\
\hline$C 1,6,8$ & 205 & 113 & 1,2 & 8,2 & 61 & 14,86 & 4,28 & 1,03 & 4.09 \\
\hline C1,6,10 & 194 & 105 & 1,0 & 7,0 & 60 & 14,53 & 4,39 & 1,00 & 3.94 \\
\hline $\mathrm{C} 1,7,8$ & 214 & 121 & 1,1 & 6,9 & 65 & 15,14 & 4,24 & 1,07 & 4.16 \\
\hline C $1,7,10$ & 205 & 113 & 1,0 & 5,9 & 63 & 14,99 & 4,35 & 1,04 & 4.07 \\
\hline $\mathrm{C} 1,8,10$ & 199 & 109 & 1,0 & 6,3 & 62 & 14,72 & 4,32 & 1,00 & 3.89 \\
\hline C6,7,8 & 210 & 121 & 1,0 & 10,4 & 64 & 15,08 & 4,24 & 1,11 & 4.21 \\
\hline $\mathrm{C} 6,7,10$ & 203 & 113 & 1,2 & 10,4 & 62 & 14,83 & 4,36 & 1,05 & 4.08 \\
\hline C6, 8,10 & 200 & 111 & 0,9 & 8,2 & 60 & 14,77 & 4,36 & 1,02 & 4.12 \\
\hline C7,8,10 & 207 & 117 & 1,1 & 7,7 & 64 & 15,01 & 4,30 & 1,06 & 4.16 \\
\hline Média & 205 & 114 & 1,0 & 8,1 & 62 & 14,91 & 4,32 & 1,04 & 4.10 \\
\hline \multicolumn{10}{|l|}{$K=4$} \\
\hline $\mathrm{C} 1,6,7,8$ & 210 & 119 & 1,1 & 8,9 & 63 & 15,07 & 4,28 & 1,07 & 4.22 \\
\hline C1, $6,7,10$ & 204 & 113 & 1,0 & 8,6 & 62 & 14,86 & 4,36 & 1,04 & 4.11 \\
\hline C1, $6,8,10$ & 200 & 110 & 1,0 & 7,5 & 61 & 14,71 & 4,34 & 1,01 & 4.03 \\
\hline C $1,7,8,10$ & 207 & 115 & 1,0 & 6,6 & 63 & 14,95 & 4,30 & 1,04 & 4.08 \\
\hline C $6,7,8,10$ & 205 & 116 & 1,0 & 9.3 & 63 & 14,90 & 4,32 & 1,06 & 4.17 \\
\hline Média & 205 & 114 & 1,0 & 8,2 & 62 & 14,90 & 4,32 & 1,04 & 4.12 \\
\hline \multicolumn{10}{|l|}{$\mathrm{K}=5$} \\
\hline$C 1,6,7,8,10$ & 206 & 115 & 1,0 & 8,2 & 62 & 14,89 & 4,32 & 1,05 & 4.13 \\
\hline
\end{tabular}

1:Taitinga, 6:Sikalq, 7:CMS 39, 8:BR 105, 10:CMS 57NF 
APÊNDICES 
Apêndice A. Composição química e física média do solo nas camadas $0-20 \mathrm{~cm}$ e $20-40 \mathrm{~cm}$ da área experimental da Fazenda Anhembi-ESALQ/USP, Piracicaba-SP, 1997.

\begin{tabular}{|c|c|c|c|c|c|c|c|c|c|c|c|c|c|}
\hline \multirow{2}{*}{$\begin{array}{c}\text { Camada } \\
\mathrm{cm}\end{array}$} & \multirow{2}{*}{$\begin{array}{c}\mathrm{pH} \\
\mathrm{CaCl} 2\end{array}$} & \multirow{2}{*}{$\begin{array}{l}\text { M.O } \\
\mathrm{g} / \mathrm{dm}^{3}\end{array}$} & \multirow{2}{*}{\multicolumn{2}{|c|}{$\begin{array}{c}P \\
\mathrm{mg} / \mathrm{dm}^{3}\end{array}$}} & $\mathrm{~K}$ & $\overline{\mathrm{Ca}}$ & $\mathrm{Mg}$ & $\mathrm{Al}$ & $\mathrm{H}+\mathrm{Al}$ & $\mathrm{SB}$ & $T$ & \multirow{2}{*}{$\begin{array}{l}\mathrm{V} \\
\%\end{array}$} & \multirow{2}{*}{$\begin{array}{l}m \\
\%\end{array}$} \\
\hline & & & & & \multicolumn{7}{|c|}{$\mathrm{m} \mathrm{mol} / \mathrm{dm}^{3}$} & & \\
\hline $0-20$ & 4,2 & 22 & & 6 & 2,2 & 18 & 11 & 10 & 52 & 31,2 & 83,2 & 38 & 24 \\
\hline $20-40$ & 4,0 & 16 & & 4 & 1,3 & 14 & 8 & 18 & 80 & 23,3 & 103,3 & 23 & 44 \\
\hline \multicolumn{14}{|c|}{ Micronutrientes } \\
\hline \multirow{2}{*}{$\begin{array}{c}\text { Camada } \\
\mathrm{cm}\end{array}$} & \multirow[t]{2}{*}{$\mathrm{B}$} & \multicolumn{3}{|c|}{$\mathrm{Cu}$} & $\mathrm{Fe}$ & & & $\overline{M n}$ & & $\mathrm{Zn}$ & & $\mathrm{Na}$ & \\
\hline & & \multicolumn{12}{|c|}{$\mathrm{mg} / \mathrm{dm}^{3}$} \\
\hline $0-20$ & 0,33 & \multirow{2}{*}{\multicolumn{3}{|c|}{$\begin{array}{l}0,9 \\
0,8\end{array}$}} & \multirow{2}{*}{\multicolumn{2}{|c|}{$\begin{array}{l}174,0 \\
91,6\end{array}$}} & \multirow{2}{*}{\multicolumn{3}{|c|}{$\begin{array}{l}6,5 \\
3,3\end{array}$}} & 0,5 & & \multicolumn{2}{|c|}{4,6} \\
\hline $20-40$ & 0,36 & & & & & & & & & 0,4 & & 4,6 & \\
\hline \multicolumn{14}{|c|}{ Análise Granulométrica } \\
\hline Camada & \multicolumn{5}{|c|}{ Areia(\%) } & Silte & \multicolumn{3}{|c|}{ Argila(\%) } & \multirow{2}{*}{\multicolumn{2}{|c|}{$\begin{array}{c}\text { Floculação } \\
\%\end{array}$}} & \multirow{2}{*}{\multicolumn{2}{|c|}{$\begin{array}{c}\text { Classe de } \\
\text { Textura }\end{array}$}} \\
\hline $\mathrm{cm}$ & MG & $M$ & $\vec{F}$ & MF & Total & $\%$ & & Total & Água & & & & \\
\hline $0-20$ & - & 15 & 38 & 8 & 65 & 8 & & 27 & 12 & & & & \\
\hline $20-40$ & - & 15 & 38 & 8 & 65 & 8 & & 27 & 12 & & & & arg \\
\hline
\end{tabular}

Apêndice B. Composição química média do solo nas camadas $0-20 \mathrm{~cm}$ e $20-40 \mathrm{~cm}$ das áreas dos experimentos 7 e 8 , sem calagem e com calagem, respectivamente, na Fazenda Anhembi-ESALQ/USP, Piracicaba-SP, 1998.

\begin{tabular}{|c|c|c|c|c|c|c|c|c|c|c|c|c|}
\hline \multirow{2}{*}{$\begin{array}{c}\text { Camada } \\
\mathrm{cm}\end{array}$} & \multirow{2}{*}{$\begin{array}{c}\mathrm{pH} \\
\mathrm{CaCl} 2\end{array}$} & \multirow{2}{*}{$\begin{array}{c}\mathrm{M} . \mathrm{O} \\
\mathrm{g} / \mathrm{dm}^{3}\end{array}$} & \multirow{2}{*}{$\begin{array}{c}\mathrm{P} \\
\mathrm{mg} / \mathrm{dm}^{3}\end{array}$} & $\mathrm{~K}$ & $\mathrm{Ca}$ & $\mathrm{Mg}$ & $\mathrm{Al}$ & $\mathrm{H}+\mathrm{Al}$ & SB & $T$ & \multirow{2}{*}{$\begin{array}{l}V \\
\%\end{array}$} & \multirow{2}{*}{$\begin{array}{l}m \\
\%\end{array}$} \\
\hline & & & & \multicolumn{7}{|c|}{$\mathrm{m} \mathrm{mol} c / \mathrm{dm}^{3}$} & & \\
\hline \multicolumn{13}{|c|}{ Experimento 7 (sem calagem) } \\
\hline $0-20$ & 4,2 & 22 & 5 & 1,8 & 14 & 13 & 10 & 58 & 28,8 & 86,8 & 33 & 26 \\
\hline $20-40$ & 3,9 & 16 & 4 & 0,3 & 6 & 6 & 26 & 72 & 12,3 & 84,3 & 15 & 68 \\
\hline \multicolumn{13}{|c|}{ Experimento 8 (com calagem) } \\
\hline $0-20$ & 4,6 & 19 & 4 & 2,4 & 18 & 20 & $\frac{1}{3}$ & 28 & 40,4 & 68,4 & 59 & 7 \\
\hline $20-40$ & 3,9 & 14 & 2 & 1,7 & 6 & 9 & 16 & 52 & 16,7 & 68,7 & 24 & 49 \\
\hline
\end{tabular}

